DOC.200.40421.0002

QA: QA

MDL-EBS-GS-000002 REV 01

April 2004

BECHTEL SAIC COMPANLC

\title{
Igneous Intrusion Impacts on Waste Packages and Waste Forms
}

Prepared for:

U.S. Department of Energy

Office of Civilian Radioactive Waste Management

Office of Repository Development

1551 Hillshire Drive

Las Vegas, Nevada 89134-6321

Prepared by:

Bechtel SAIC Company, LLC

1180 Town Center Drive

Las Vegas, Nevada 89144

Under Contract Number

DE-AC28-01RW12101 


\section{DISCLAIMER}

This report was prepared as an account of work sponsored by an agency of the United States Government. Neither the United States Government nor any agency thereof, nor any of their employees, nor any of their contractors, subcontractors or their employees, makes any warranty, express or implied, or assumes any legal liability or responsibility for the accuracy, completeness, or any third party's use or the results of such use of any information, apparatus, product, or process disclosed, or represents that its use would not infringe privately owned rights. Reference herein to any specific commercial product, process, or service by trade name, trademark, manufacturer, or otherwise, does not necessarily constitute or imply its endorsement, recommendation, or favoring by the United States Government or any agency thereof or its contractors or subcontractors. The views and opinions of authors expressed herein do not necessarily state or reflect those of the United States Government or any agency thereof. 


\section{OCRWM}

\section{Model Signature Page/Change History}

2. Type of Mathematical Model

X Process Model

Abstraction Model

System Model

Describe Intended Use of Model

This model will assess the impacts of igneous intrusion event on the Total Repository System Performance

\section{Title}

Igneous Intrusion Impacts on Waste Packages and Waste Forms

4. DI (including Rev. No. and Change No., if applicable):

MDL-EBS-GS-000002 REV01

5. Total Appendices

Four (4)
6. No. of Pages in Each Appendix

I-8; II-7, III-1 plus 2 CD ROMS; IV-19

\begin{tabular}{|l|l|l|}
\hline 7. Originator & Printed Name & Patricia Bernot \\
\hline \begin{tabular}{l} 
8. $\begin{array}{l}\text { Independent Technical } \\
\text { Reviewer }\end{array}$ \\
\hline 9. Checker
\end{tabular} & Steve Alcorn \\
\hline 10. QER & Darrell Svalstad \\
\hline 11. Responsible Manager/Lead & Howard Adkins \\
\hline 12. Responsible Manager & Paul Dixon \\
\hline 13. Remarks &
\end{tabular}

REV 01 authors: Patricia Bernot with assistance from Emma Thomas and John Case.

This report was checked by Steve Alcorn with assistance from Susan LeStrange and Kaveh Zarrabi.

\section{Change History}

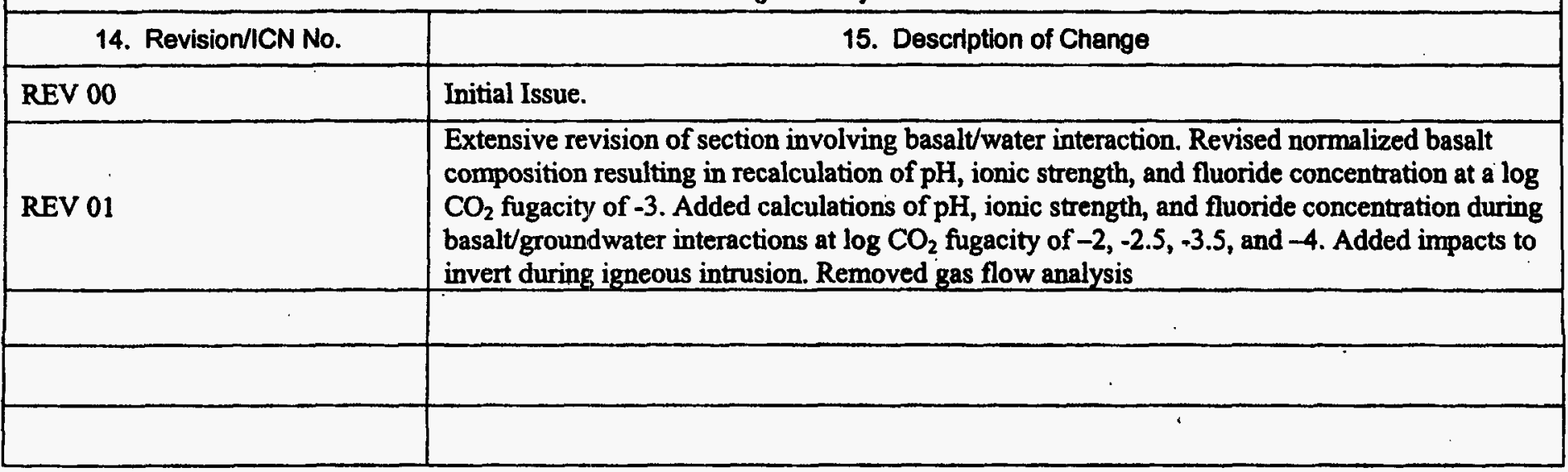




\section{CONTENTS}

1. PURPOSE .1

2. QUALITY ASSURANCE .2

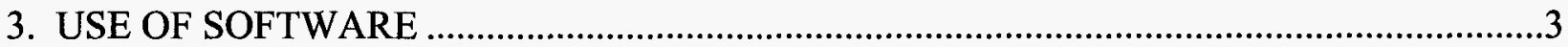

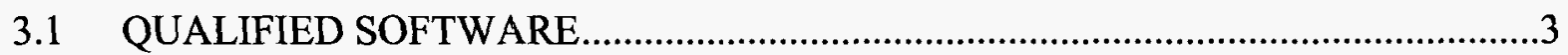

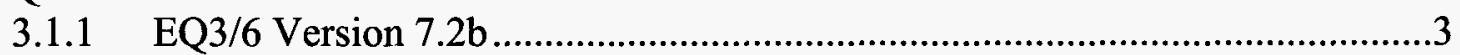

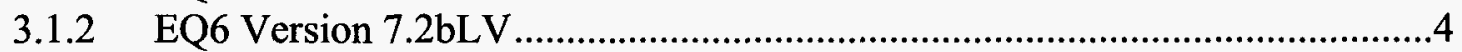

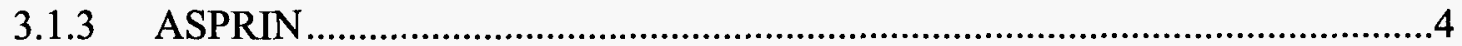

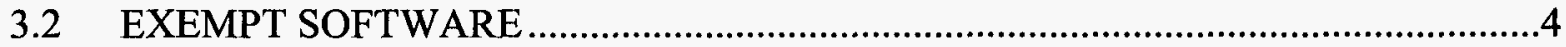

4. INPUTS

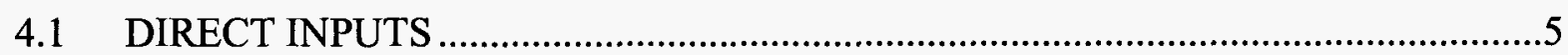

4.1.1 Inputs for Heat Flow Calculations and Model Simulations ..............................6

4.1.2 Inputs for EQ6 Simulation of Water/Basalt Reaction Hydrochemistry ............7

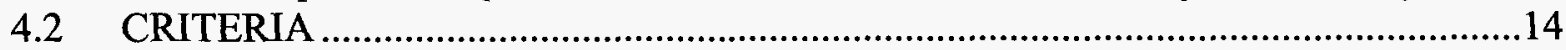

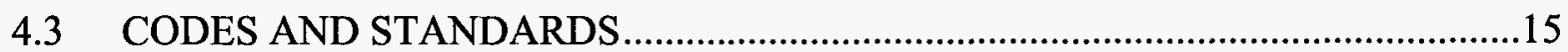

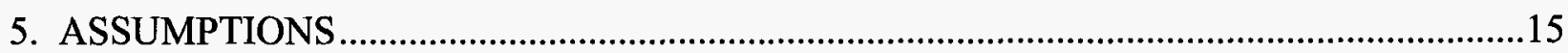

5.1 Permeability of Metamorphic Aureole and Cooled Basalt .............................15

5.2 Fracturing of Basalt and Block Size ...............................................................15

5.3 Thermal Properties of the Magma ..................................................................16

5.4 Exsolved Volcanic Gas Movement from Zone 1 to Zone 2 Emplacement Drifts Due to Dike Intrusion............................................................................16

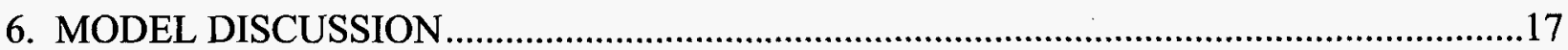

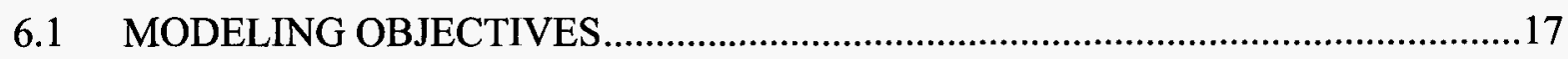

6.2 INCLUDED FEATURES, EVENTS AND PROCESSES …….................................18

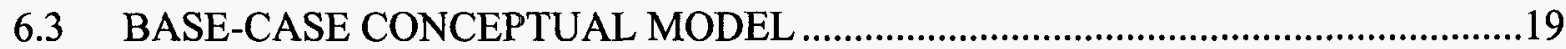

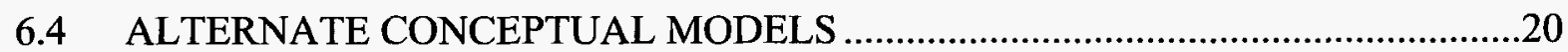

6.4.1 Reaction Between Waste Forms, Metals, and Basalt .....................................20

6.4.2 Reaction Between Corrosion Products, Metals, and Basalt ............................21

6.4.3 Permeability of Contact Metamorphic Aureole ................................................22

6.4.4 Fragmentation of Waste Forms ………………......................................22

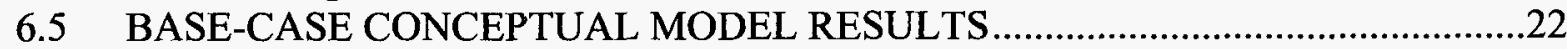

6.5.1 Intrusion of Basalt Magma into Zone 1 Emplacement Drifts .........................24

6.5.2 Heat and Gas Flow from Zone 1 Emplacement Drifts Filled with Basalt

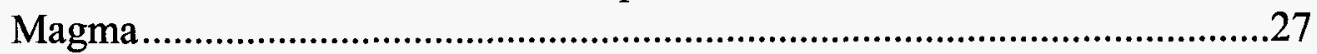

6.5.3 Reaction of Seepage Water with Basalt After Reversion to Normal InDrift Environmental Conditions..................................................................32

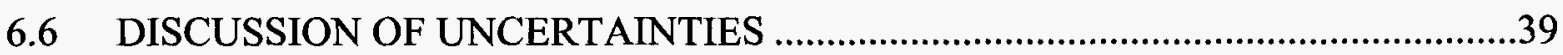

6.6.1 Uncertainty in Heat Conduction Analysis......................................................

6.6.2 Uncertainty in the Geochemical Modeling Using EQ6..................................40 
6.7 IMPLEMENTATION OF IGNEOUS INTRUSION MODEL FOR TSPA-LA .........44

6.7.1 Igneous Intrusion Impacts on Zone 1 Materials ........................................44

6.7.2 Crown Seepage Reaction with Cooled Basalt .............................................45

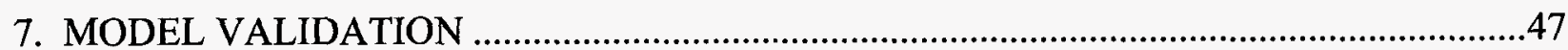

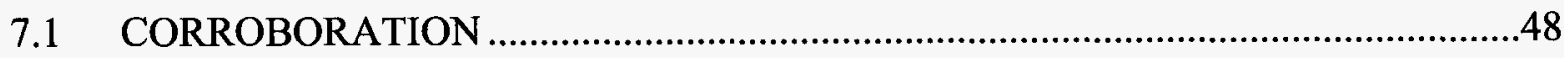

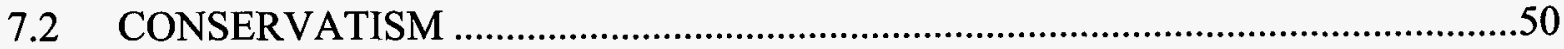

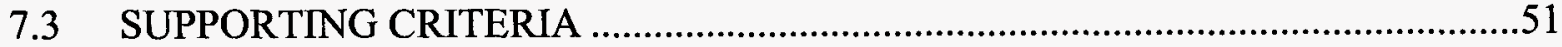

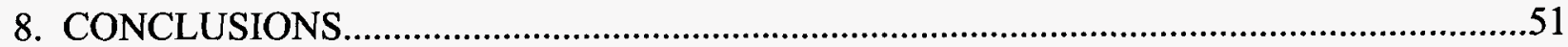

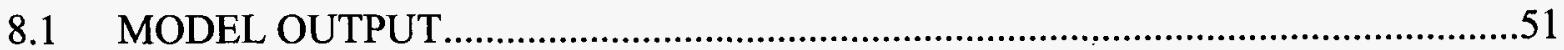

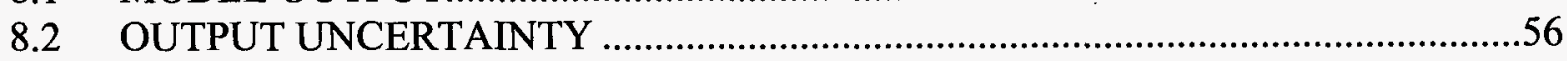

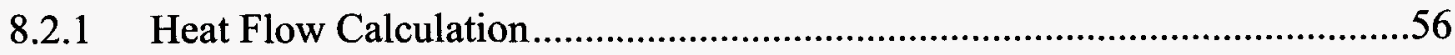

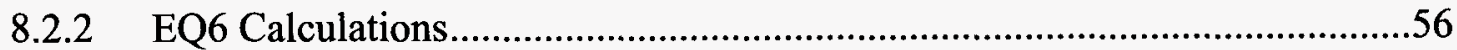

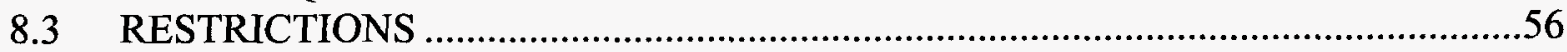

8.4 YUCCA MOUNTAIN REVIEW PLAN ACCEPTANCE CRITERIA ....................57

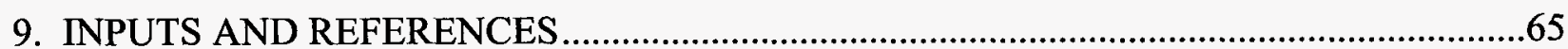

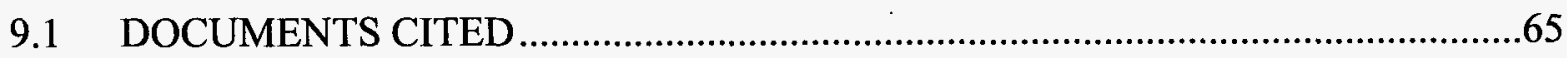

9.2 CODES, STANDARDS, REGULATIONS, AND PROCEDURES ........................70

9.3 SOURCE DATA, LISTED BY DATA TRACKING NUMBER ….........................71

9.4 OUTPUT DATA, LISTED BY DATA TRACKING NUMBER ...........................71

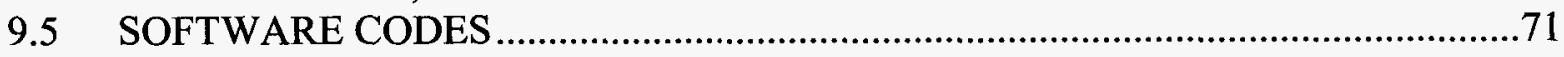

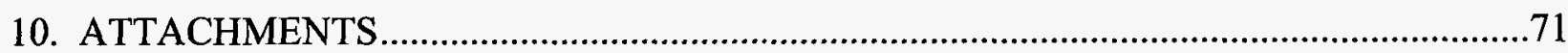




\section{FIGURES}

Page

Figure 6-1. Heat Conduction from Magma Flow for Dry Tptpll..............................................29

Figure 6-2. Heat Conduction from Magma Flow for Wet Tptpll ..................................................29

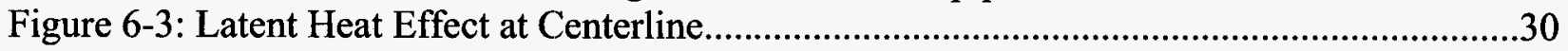

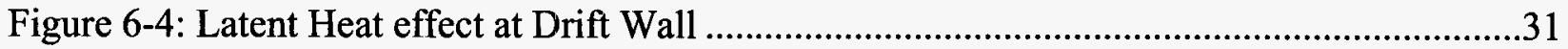

TABLES

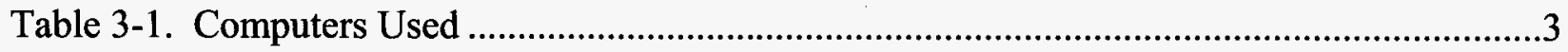

Table 3-2. Qualified Computer Software Used in the Igneous Intrusion Impacts Model ...............3

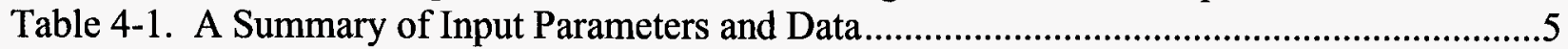

Table 4-2. Summary of Primary Thermal Conductivity Statistics ...............................................6

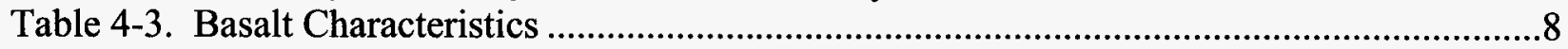

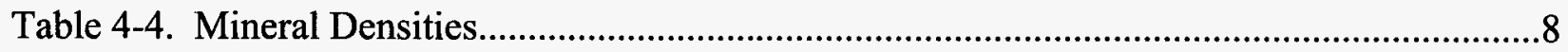

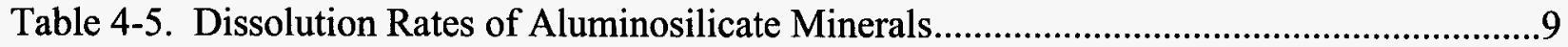

Table 4-6. Dissolution Rates of Olivine and Pyroxene Minerals .................................................10

Table 4-7. Dissolution Rates of Hydroxylapatite, Magnetite, and Ilmenite ...............................11

Table 4-8. Water Composition and Redox Conditions Used in EQ3 ……...............................12

Table 4-9. Parameter and Values Changes for Abstraction Cases for Basalt/Water

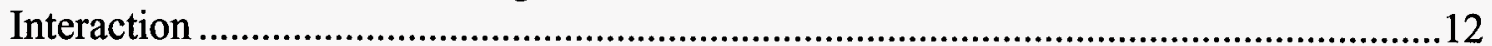

Table 4-10. Water Composition and Redox Conditions Used in the EQ3 for Sensitivity

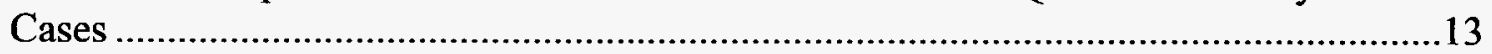

Table 6-1. Included FEP for This Model Report and Its Disposition in TSPA-LA .....................19

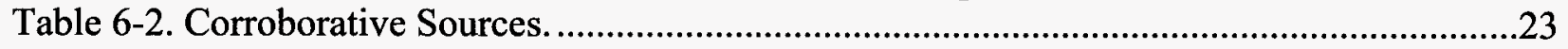

Table 6-3. Idealized Mineral Composition of Basalt........................................................................

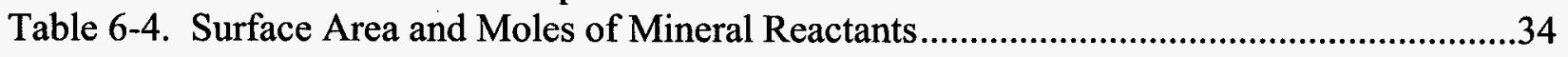

Table 6-5. Dissolution Rates of Basaltic Minerals ...................................................................

Table 6-6. Water Composition and Flow Rate Used in the EQ3/6 Input Files of Water/Basalt Interaction ............................................................................................

Table 6-7. Surface Area and Moles of Mineral Reactants with Different Pore Fraction and

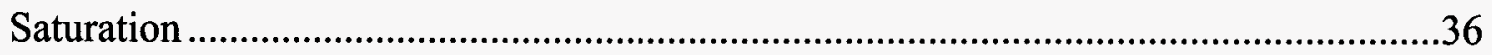

Table 6-8. Elements Added as "Trace" to Water.....................................................................

Table 6-9. Water Composition Used in the EQ3/6 Input Files of Water/Basalt Interaction for Sensitivity Cases ................................................................................................38

Table 6-10. Composition of Lathrop Wells Cone Basalt...........................................................41

Table 6-11. Temporal Maximum and Minimum Values for $\mathrm{pH}$ and Ionic Strength .....................43

Table 6-12. Temperature of Waste Forms Inside Intruded Magma Body ......................................45

Table 8-1. Look-Up Tables for Temperature of Waste Forms .....................................................54

Table 8-2. Look-Up Table of Temporal Maximum and Minimum Values for $\mathrm{pH}$ and Ionic

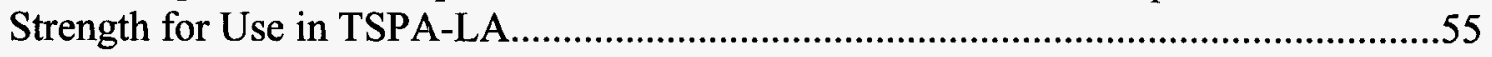

Table 8.3. Valid Range of $\mathrm{pH}$ and Ionic Strength Reported in This Model Report .....................57 


\section{ACRONYMS}

DR dissolution rate

EBS engineered barrier system

FEP feature, event, or process

TSPA Total System Performance Assessment

TSPA-LA Total System Performance Assessment for the License Application 


\section{PURPOSE}

The purpose of this model report is to assess the potential impacts of igneous intrusion on waste packages and waste forms in the emplacement drifts at the Yucca Mountain Repository. The models are based on conceptual models and includes an assessment of deleterious dynamic, thermal, hydrologic, and chemical impacts. The models described in this report constitute the waste package and waste form impacts submodel of the Total System Performance Assessment for the License Application (TSPA-LA) model assessing the impacts of a hypothetical igneous intrusion event on the repository total system performance. This submodel is carried out in accordance with Technical Work Plan for Waste Form Degradation Modeling, Testing, and Analyses in Support of LA (BSC 2004 [DIRS:167796]) and Total System Performance Assessment-License Application Methods and Approaches (BSC 2003 [DIRS:166296]). The technical work plan was prepared in accordance with AP-2.27Q, Planning for Science Activities. Any deviations from the technical work plan are documented in the following sections as they occur.

The TSPA-LA approach to implementing the models for waste package and waste form response during igneous intrusion is based on identification of damage zones. Zone 1 includes all emplacement drifts intruded by the basalt dike, and Zone 2 includes all other emplacement drifts in the repository that are not in Zone 1. This model report will document the following model assessments:

- Mechanical and thermal impacts of basalt magma intrusion on the invert, waste packages and waste forms of the intersected emplacement drifts of Zone 1.

- Temperature and pressure trends of basaltic magma intrusion intersecting Zone 1 and their potential effects on waste packages and waste forms in Zone 2 emplacement drifts.

- Deleterious volatile gases, exsolving from the intruded basalt magma and their potential effects on waste packages of Zone 2 emplacement drifts.

- Post-intrusive physical-chemical environment and seepage water alteration by reaction with intruded basalt.

The scope of this model only includes impacts to the components stated above, and does not include impacts to other engineered barrier system (EBS) components such as the waste package pallet.

The results of this model report will be used in TSPA for several parameters including 1) temperature of magma (used for the temperature of the waste form after an intrusion) 2) temperature increase in Zone 2 due to intrusion to evaluate impact to Zone 2 waste packages; 3 ) effects of exsolved gases reaching Zone 2 to evaluate impact to Zone 2 waste packages; and 4) $\mathrm{pH}$ and ionic strength of water reacted with basalt to be used in conjunction with Dissolved Concentration Limits of Radioactive Elements (BSC 2003 [DIRS:163152]) to determine solubility of spent fuel within the basalt. Ionic strength will also be used in conjunction with Waste Form and In-Drift Colloids-Associated Radionuclide Concentrations: Abstraction and Summary (BSC 2003 [DIRS: 166845]) for stability of colloids. 
The $\mathrm{pH}$ and ionic strength values developed in this model report for reaction of seepage water and basalt are valid for the range of parameters listed in Table 8-3.

Consequences of igneous activity to the Yucca Mountain Repository are evaluated in TSPA-LA models for the eruptive (volcanic eruption intersecting repository causing direct release of radioactive waste) and igneous-intrusion groundwater-transport modeling cases (damage to waste packages that are engulfed or otherwise affected by igneous intrusion) (BSC 2003 [DIRS 166296]). This model report explicitly supports the igneous-intrusion groundwater-transport modeling case (BSC 2003 [DIRS 166296]) by providing impacts to waste packages and waste forms due to igneous intrusion and changes in groundwater chemistry caused by water percolating through a basalt filled drift. Other features of an igneous event are captured in other model reports. Characterize Eruptive Processes at Yucca Mountain, Nevada (BSC 2003 [DIRS:166407]) provides information about natural volcanic systems and provides parameters that can be used to model their behavior. Parameters provided are appropriate for analysis of the consequences of volcanic eruptions at Yucca Mountain. Number of Waste Packages Hit by Igneous Intrusion (BSC 2004 [DIRS:164650) calculates the number of waste packages that could be damaged in a potential future igneous disruption. Dike/Drift Interactions (BSC 2003 [DIRS:165923]) provides an analysis of the intersection of ascending magma with repository drifts including a discussion on dike propagation, magma flow, and gas flow and conductive cooling of a magma cooled drift. Atmospheric Dispersal and Deposition of Tephra from a potential Volcanic Eruption at Yucca Mountain (BSC 2004 [DIRS:167616]) (referred to as ASHPLUME) provides information on the redistribution of contaminated tephra from a potential volcanic eruption for the prediction of radioactive waste/ash deposition on the ground surface.

\section{QUALITY ASSURANCE}

Development of this model report has been determined to be subject to the Yucca Mountain Project's quality assurance program (BSC 2004 [DIRS:167796], Attachment I) because it will support performance assessment. This report was prepared in accordance with AP-SIII-10Q, Models, and reviewed in accordance AP-2.14Q, Document Review. The development of this report does not investigate any items on the Q-List.

The control of the electronic media was evaluated in accordance with AP-SV.1Q, Control of Electronic Management of Information. Methods used for electronic information control include:

- Records submitted in accordance with AP-17.1Q, Records Management, and AP-6.1Q, Document Control, and are retrievable through the Records Processing Center.

- Engineering technical information stored on CD-ROMs that are not rewriteable. Conditions, location, retention time, and access are through the records center following submittal in accordance with AP-17.1Q and AP-6.1Q.

- Media identified in accordance with AP-17.1Q and AP-SIII.10Q. 


\section{USE OF SOFTWARE}

This section describes the computer software used to conduct the modeling of thermal and chemical impacts of igneous intrusion. All applicable products are obtained from Software Configuration Management and have been verified appropriate for the application. The software products are run on standard computers listed in Table 3-1.

Table 3-1. Computers Used

\begin{tabular}{|c|l|l|l|}
\hline Computer Make & \multicolumn{1}{|c|}{ CPU \# } & \multicolumn{1}{|c|}{ Operating System } & \multicolumn{1}{c|}{ Software Used } \\
\hline Dell Optiplex GX300 & 117728 & Windows 95 & EQ3/6 V7.2b, EQ6 V7.2bLV, ASPRIN \\
\hline Dell Optiplex GX260 & 152393 & Windows 2000 & Microsoft Excel \\
\hline
\end{tabular}

\subsection{QUALIFIED SOFTWARE}

A brief description of the computer software is included in Table 3-2. More in-depth descriptions of the software follows.

Table 3-2. Qualified Computer Software Used in the Igneous Intrusion Impacts Model

\begin{tabular}{|c|c|c|c|c|}
\hline $\begin{array}{c}\text { Software } \\
\text { Name }\end{array}$ & Version & $\begin{array}{c}\text { Software Tracking } \\
\text { Number }\end{array}$ & $\begin{array}{l}\text { Description and } \\
\text { Components Used }\end{array}$ & Input and Output Files \\
\hline \multirow[t]{2}{*}{ EQ3/6 } & \multirow[t]{2}{*}{ Version $7.2 b$} & \multirow{2}{*}{$\begin{array}{l}\text { LLNL: UCRL-MA-110662 } \\
\text { (Qualified on Windows 95) }\end{array}$} & $\begin{array}{l}\text { EQ3NR: a speciation- } \\
\text { solubility code }\end{array}$ & $\begin{array}{ll}\text { Input: } & { }^{*} .3 \mathrm{i} \\
\text { Pickup: } & { }^{*} .3 p \\
\text { Output: } & * \\
\end{array}$ \\
\hline & & & $\begin{array}{l}\text { EQPT: a data file } \\
\text { preprocessor }\end{array}$ & $\begin{array}{l}\text { Input: data0.* } \\
\text { Output: data1.* }\end{array}$ \\
\hline EQ6 & Version $7.2 \mathrm{bLV}$ & $\begin{array}{l}\text { 10075-7.2bLV-00 } \\
\text { (Qualified on Windows 95) }\end{array}$ & $\begin{array}{l}\text { EQ6: a reaction path } \\
\text { code which models } \\
\text { water/rock interaction or } \\
\text { fluid mixing in either a } \\
\text { pure reaction progress } \\
\text { mode or a time mode }\end{array}$ & $\begin{array}{ll}\text { Input: } & { }^{*} .6 \mathrm{i} \\
\text { Pickup: } & { }^{*} .6 \mathrm{p} \\
\text { Output: } & { }^{*} .6 \mathrm{o} \\
& { }^{*} . \text { elem_aqu.txt } \\
& { }^{*} . \text { elem_min.txt } \\
& { }^{*} . \text { elem_tot.txt } \\
& { }^{*} . \text { min_info.txt } \\
& { }^{*} . \text {.bin } \\
\end{array}$ \\
\hline ASPRIN & Version 1 & $\begin{array}{l}10487-1.0-00 \\
\text { (Qualified on Windows 95) }\end{array}$ & $\begin{array}{l}\text { Performs post- } \\
\text { processing of numerical } \\
\text { information from EQ6 }\end{array}$ & $\begin{array}{l}\text { Input: } \quad * \text {.bin } \\
\text { Output: }{ }^{*} . \mathrm{txt}\end{array}$ \\
\hline
\end{tabular}

\subsubsection{EQ3/6 Version 7.2b}

The major components of the EQ3/6 package (EQ3/6 V7.2b, STN: LLNL UCRL-MA-110662) include EQ3NR, a speciation-solubility code; EQ6, a reaction path code which models water/rock interaction or fluid mixing in either a pure reaction progress mode or a time mode; EQPT, a data file preprocessor; EQLIB, a supporting software library; and several supporting thermodynamic data files. The software deals with the concepts of thermodynamic equilibrium, thermodynamic disequilibrium, and reaction kinetics. EQPT takes a formatted data file (a "data0" file) and writes an unformatted near-equivalent called a "datal" file, which is actually 
the form read by EQ3NR and EQ6. EQ3NR is used for analyzing groundwater chemistry data, calculating chemical species, solubility limits, and determining whether certain reactions are in states of partial equilibrium or disequilibrium. EQ3NR is also required to initialize an EQ6 calculation.

EQ6 calculates the consequences of exposing an aqueous solution to a set of reactants. It can also analyze fluid mixing and the consequences of changes in temperature. This code operates both in a pure reaction progress frame and in a time frame. In a time frame calculation, the user specifies rate laws for the progress of the irreversible reactions. Otherwise, only relative rates are specified. EQ3NR and EQ6 use a hybrid Newton-Raphson technique to make thermodynamic calculations. This is supported by a set of algorithms that create and optimize starting values. EQ6 uses an ordinary differential equation integration algorithm to solve rate equations in time mode.

\subsubsection{EQ6 Version 7.2bLV}

EQ6 7.2bLV (EQ6 V7.2bLV, STN: 10075-7.2bLV-00) contains the solid-centered flow-through mode that allows water to enter the basalt in Zone 1, flow through and react with minerals, and eventually flow out of the basalt block. EQ6 version $7.2 \mathrm{bLV}$ is also capable of incorporating radioactive decay and passing time-varying aqueous compositions from run to run. However, these two new features were not required for the basalt/water interaction analysis in this model, so were not employed.

\subsubsection{ASPRIN}

ASPRIN Version 1 (ASPRIN V1.0, STN: 10487-1.0-00) performs post-processing of numerical information from an output data file created by EQ6 (*.bin). Although originally designed to calculate the isotopic inventory of radionuclides, this program is also able to extract output data (i.e., moles left of materials, solution composition, etc.) from the binary file produced as EQ6 Version 7.2bLV output.

\subsection{EXEMPT SOFTWARE}

Microsoft Excel (EXCEL 97') is a problem-solving environment used in calculations and analyses. It is also used to tabulate and chart results. The user-defined expressions, inputs, and results are documented in sufficient detail to allow an independent repetition of computations. Thus, Microsoft Excel is used for graphical representation and arithmetical manipulations in worksheets and not as software routines. Therefore it is used as commercial off-the-shelf software and is exempt in accordance with LP-SI.11Q-BSC, Software Management. The formulae and algorithms used for Microsoft Excel, including the inputs (*.txt files) and outputs (*.xls files), are given in the attachments.

\section{INPUTS}

All of the information in the following subsections is used as direct input to the Igneous Intrusion Impacts Model. Discussion of input uncertainties is included in Section 6.6. 


\subsection{DIRECT INPUTS}

A summary of input data and parameters used in the model and related analyses are presented in Table 4-1. Details of all input data are given in subsequent sections of Section 4. All calculated inputs are presented in Section 6.5 within their respective sections. Discussion of uncertainty in the input parameters is addressed in Section 6.6.

Table 4-1. A Summary of Input Parameters and Data

\begin{tabular}{|c|c|c|c|}
\hline Model component & Input & Reference document & Section \\
\hline $\begin{array}{l}\text { Intrusive impacts on } \\
\text { waste package and } \\
\text { waste forms }\end{array}$ & $\begin{array}{l}\text { Initial intrusive magma } \\
\text { conditions }\end{array}$ & BSC 2003 [DIRS:166407] & Section 6.5 \\
\hline \multirow{4}{*}{ Intrusive heat flow } & $\begin{array}{l}\text { Thermal conductivities, porosity } \\
\text { and density of rock units } \\
\text { (Values in Table } 4-2 \text { of this } \\
\text { report) }\end{array}$ & $\begin{array}{l}\text { BSC } 2002 \text { [DIRS:160319], } \\
\text { Table } 7-10\end{array}$ & \multirow{4}{*}{$\begin{array}{l}\text { Attachment I } \\
\text { Corresponding } \\
\text { results presented } \\
\text { in Section } 6.5 .2\end{array}$} \\
\hline & $\begin{array}{l}\text { Mean and Standard Deviation } \\
\text { values for uncertainty analysis } \\
\text { (Delta Method) }\end{array}$ & BSC 2004 [DIRS:168720] & \\
\hline & $\begin{array}{l}\text { Heat capacity (Values in Table } \\
4-2 \text { of this report) }\end{array}$ & DTN: SN0307T0510902.003 & \\
\hline & density $\&$ specific heat of water & $\begin{array}{l}\text { Incropera and DeWitt 2002, } \\
924 \text {, Table A. } 6\end{array}$ & \\
\hline \multirow{13}{*}{$\begin{array}{l}\text { Reaction of seepage } \\
\text { water with cooled basalt } \\
\text { in EQ6 }\end{array}$} & $\begin{array}{l}\text { Dissolution of nepheline (Table } \\
\text { 4-7 of this report) }\end{array}$ & Tole et al. 1986 & \multirow{13}{*}{$\begin{array}{l}\text { Attachment III } \\
\text { Corresponding } \\
\text { results presented } \\
\text { in Section 6.5.3 }\end{array}$} \\
\hline & $\begin{array}{l}\text { Dissolution of albite (Table 4-7 } \\
\text { of this report) }\end{array}$ & Chou and Wollast 1985 & \\
\hline & $\begin{array}{l}\text { Dissolution of anorthite and } \\
\text { enstatite (Values in Tables } 4.7 \\
\text { and } 4-8 \text { of this report) }\end{array}$ & Brady and Walther 1989 & \\
\hline & $\begin{array}{l}\text { Dissolution of olivine (Values in } \\
\text { Table } 4-8 \text { of this report) }\end{array}$ & Wogelius and Walther 1991 & \\
\hline & $\begin{array}{l}\text { Dissolution of diopside (Values } \\
\text { in Table 4-8 of this report) }\end{array}$ & Brantley and Chen 1995 & \\
\hline & $\begin{array}{l}\text { Dissolution of Hydroxylapatite } \\
\text { (Values in Table } 4-9 \text { of this } \\
\text { report) }\end{array}$ & Valsami-Jones et al., 1998 & \\
\hline & $\begin{array}{l}\text { Dissolution of Magnetite and } \\
\text { Ilmenite (Values in Table 4-9 of } \\
\text { this report) }\end{array}$ & White et al., 1994 & \\
\hline & $\begin{array}{l}\text { Basaltic composition in oxides } \\
\text { (Values in Table } 4-5 \text { of this } \\
\text { report) }\end{array}$ & $\begin{array}{l}\text { BSC } 2003 \text { [DIRS:166407], } \\
\text { Table } 6\end{array}$ & \\
\hline & $\begin{array}{l}\text { Density of minerals (Table 4-6 } \\
\text { of this report) }\end{array}$ & Roberts et al. 1990 & \\
\hline & Atomic weights of elements & Parrington et al. 1996 & \\
\hline & Pore fractions & $\begin{array}{l}\text { BSC } 2002 \text { [DIRS:160319], } \\
\text { Table 7-10 }\end{array}$ & \\
\hline & Flux rate & DTN:LB0310AMRU0120.001 & \\
\hline & Saturation & BSC 2004 [DIRS:168848] & \\
\hline
\end{tabular}


Table 4-1 (continued). A Summary of Input Parameters and Data

\begin{tabular}{|l|l|c|c|}
\hline \multicolumn{1}{|c|}{ Model component } & \multicolumn{1}{|c|}{ Input } & \multicolumn{1}{|c|}{ Reference document } & \multicolumn{1}{c|}{ Section } \\
\hline \multirow{4}{*}{$\begin{array}{l}\text { EQ3 input water } \\
\text { compositions }\end{array}$} & $\begin{array}{l}\text { Bin 8 seepage water (Table 4- } \\
10 \text { of this report) }\end{array}$ & DTN: MO0310SPAEBSCB.003 & Attachment III \\
\cline { 2 - 4 } & $\begin{array}{l}\text { Bin 11 seepage water (Table 4- } \\
12 \text { of this report) }\end{array}$ & DTN: MO0310SPAEBSCB.003 & $\begin{array}{l}\text { Corresponding } \\
\text { results presented } \\
\text { in Section 6.5.3 }\end{array}$ \\
\cline { 2 - 4 } & $\begin{array}{l}\text { J-13 well water (Table 4-12 of } \\
\text { this report) }\end{array}$ & DTN: MO0006J13WTRCM.000 & \\
\hline
\end{tabular}

\subsubsection{Inputs for Heat Flow Calculations and Model Simulations}

The primary thermal conductivity statistics are contained in Table 4-2.

Table 4-2. Summary of Primary Thermal Conductivity Statistics

\begin{tabular}{|c|c|c|c|c|c|c|}
\hline$\underset{\text { Unit }}{\text { Stratigraphic }}$ & $\begin{array}{c}\text { Bulk Dry Rock } \\
\text { Mass Thermal } \\
\text { Conductivity, } k_{m} \\
(W / m \cdot K)\end{array}$ & $\begin{array}{c}\text { Bulk Wet Rock } \\
\text { Mass Thermal } \\
\text { Conductivity, } k_{m} \\
(\mathrm{~W} / \mathrm{m} \cdot \mathrm{K})\end{array}$ & $\begin{array}{c}\text { Matrix } \\
\text { Porosity, } \phi_{m}\end{array}$ & $\begin{array}{l}\text { Lithophysal } \\
\text { Porosity, } \phi_{1}\end{array}$ & $\mid \begin{array}{c}\text { Dry Bulk } \\
\text { Density, } \rho_{b d} \\
\left(\mathbf{k g} / \mathrm{m}^{3}\right)\end{array}$ & $\begin{array}{c}\text { Specific Heat } \\
\text { Capacity of } \\
\text { Solids, } C_{p} \\
\mathrm{~J} /(\mathrm{g} \cdot \mathrm{K})\end{array}$ \\
\hline Tptpul & 1.18 & 1.77 & 0.17 & 0.12 & 1830 & 0.93 \\
\hline Tptpmn & 1.42 & 2.07 & 0.13 & 0.03 & 2150 & 0.93 \\
\hline Tptpll & 1.28 & 1.89 & 0.15 & 0.09 & 1980 & 0.93 \\
\hline Tptpln & 1.49 & 2.13 & 0.11 & 0.03 & 2210 & 0.93 \\
\hline
\end{tabular}

Source: BSC 2002 [DIRS:160319], Table 7-10, DTN:SN0307T0510902.003

NOTE: Porosity is the ratio of void volume to total rock volume, and has units of $\mathrm{m}^{3} \mathrm{void} / \mathrm{m}^{3}$ rock.

The following equations (from Attachment I) and parameter were used for the heat flow analysis in Attachment I:

- Equation I-1: Equation for one-dimensional unsteady heat conduction in a rod model, subject to constant heat content (Chapman 1974, p. 137).

- Equation I-2: Equation for finite difference expression approximations to first and second order derivatives for the radial heat conduction (Carnahan et al. 1990, p. 462).

- Equation I-8: Equation for volumetric heat capacity (BSC 2004 [DIRS:168720], Equation II-15).

- Equation I-11: Equation for grain density of solids (BSC 2002 [DIRS:160319], p. 41, Equation 6-4).

- Liquidus temperature of intruding magma $=1046$ to $1169^{\circ} \mathrm{C}(\mathrm{BSC} 2003$ [DIRS:166407], Table 8).

The sources for the conductivity, porosity, dry bulk density and heat capacity listed in Table 4-2, and the temperature of the intruding magma are appropriate input for this report because they come from project work conducted specifically for the purpose of gathering this type of information for the project and completed under the same quality program. The use of the 
equations by Heat Transfer (Chapman 1974) and Applied Numerical Methods (Carnahan et al. 1990) for the heat conduction model are appropriate because they are well-accepted heat transfer handbooks. For simplicity, the model for one-dimensional flow is a very idealized concept of heat transfer, but it is conservative because it predicts the maximum heat flow by neglecting axial flow. The equations for volumetric heat capacity and grain density are appropriate input for this report because they come from project documents completed under the same quality program.

\subsubsection{Inputs for EQ6 Simulation of Water/Basalt Reaction Hydrochemistry}

For EQ3/6 calculations, the incoming water composition is run through EQ3NR. The output composition from EQ3NR (in the form of a pick up file, See Section 3) then becomes part of the EQ6 input file. In addition to the incoming water composition provided through EQ3NR, EQ6 also requires surface area, moles, and reaction rate (in this case, TST rates) of reactants (minerals) as inputs. These inputs were calculated through spreadsheet analysis and are presented in 6.5.3. Direct inputs that feed those spreadsheet analyses are presented in this section.

\subsubsection{Composition for Intruded Basalt Material}

The basalt characteristics in Table 4-3 serve as the basis for the calculations of basalt/water interaction. The densities of normalized minerals (mineral species calculated in "basaltseparated.xls" in Attachment III, Disc 1) are included in Table 4-4. The converted values (for normalized minerals) used for EQ6 calculations are located in Section 6.5.3. This composition was derived in BSC 2003 [DIRS:166407] through analysis of 45 samples taken from the Lathrop Wells Cone. The Lathrop Wells Cone is the youngest volcanic center in the Yucca Mountain region, and is therefore considered an adequate analog for the composition of a possible igneous intrusion into Yucca Mountain. The mineral densities used in the model calculations (Table 4-4) come from a handbook data source and are considered appropriate for use in the model. The saturation values chosen are those for the maximum and minimum saturation found in BSC 2004 ([DIRS:168848] Table 6.4-1). Saturation values are discussed further in Section 4.1.2.3. A high pore fraction will allow maximum exposure of water with the basalt. Effects of pore fraction on water chemistry was investigated in the EQ6 calculation (as indicated in Section 6.5.3.1) and is part of the abstracted values in Table 6-11. 
Table 4-3. Basalt Characteristics

\begin{tabular}{|c|c|c|c|}
\hline \multicolumn{4}{|c|}{ Basalt Composition $^{\mathrm{a}}$} \\
\hline Oxide & Mean Wt\% & Oxide & Mean Wt\% \\
\hline $\mathrm{SiO}_{2}$ & 48.5 & $\mathrm{~K}_{2} \mathrm{O}$ & 1.84 \\
\hline $\mathrm{Al}_{2} \mathrm{O}_{3}$ & 16.74 & $\mathrm{TiO}_{2}$ & 1.93 \\
\hline $\mathrm{Fe}_{2} \mathrm{O}_{3}$ & 1.74 & $\mathrm{P}_{2} \mathrm{O}_{5}$ & 1.22 \\
\hline $\mathrm{MgO}$ & 5.83 & $\mathrm{MnO}$ & 0.17 \\
\hline $\mathrm{CaO}$ & 8.6 & $\mathrm{FeO}$ & 8.9 \\
\hline $\mathrm{Na}_{2} \mathrm{O}$ & 3.53 & Total & 99 \\
\hline Pore fraction $=0.17^{\mathrm{b}}$ & & \\
\hline Saturation $=0.12^{\mathrm{c}}$ \\
\hline
\end{tabular}

Sources: ${ }^{\mathrm{a}}$ BSC 2003 [DIRS: 166407], Table 6

${ }^{b}$ BSC 2002 [DIRS:160319], Table 7-10

${ }^{\mathrm{C}}$ BSC 2004 [DIRS:168848]. Table 6.4-1

Table 4-4. Mineral Densities

\begin{tabular}{|l|l|l|l|}
\hline \multicolumn{1}{|c|}{ Mineral } & \multicolumn{1}{c|}{ Density (g/cm $\left.{ }^{3}\right)$} & \multicolumn{1}{c|}{ Mineral } & \multicolumn{1}{c|}{ Density (g/cm $\left.{ }^{3}\right)$} \\
\hline Anorthite & $2.74-2.76(\mathrm{p} .32)$ & Fayalite & $4.32(\mathrm{p} .268)$ \\
\hline Albite & $2.60-2.63(\mathrm{p} .12)$ & Forsterite & $3.275(\mathrm{p} .291-292)$ \\
\hline Nepheline & $2.55-2.665(\mathrm{p} .603)$ & Hedenbergite & $3.50-3.56(\mathrm{p} .353)$ \\
\hline Sanidine & $2.56-2.62(\mathrm{p} .754)$ & Enstatite & $3.209-3.431(\mathrm{p} .250)$ \\
\hline Magnetite & $5.175(\mathrm{p} .515)$ & Hydroxylapatite & $3.08(\mathrm{p} .389)$ \\
\hline limenite & $4.72(\mathrm{p} .394)$ & & \\
\hline
\end{tabular}

Source: Roberts et al. 1990.

NOTE: All density values are for measured density.

The minerals indicated in Table 4-4 were derived from normative analysis of oxides in Table 43. The normative analysis is presented in Section 6.5.3. Uncertainty from using a normative composition rather than a strictly modal composition is presented in Section 6.6.2.

\subsubsection{Dissolution Rates of Basalt Materials/Minerals}

The dissolution rates of minerals come from various literature sources and are presented in Tables 4-5, 4-6, and 4-7 below. These values are used in Microsoft Excel spreadsheets in Attachment III (Disc 1) to calculate EQ6 dissolution rates for minerals. These calculated rates are presented in Section 6.5.3.1 and Attachment II. All of the values for mineral dissolution (presented in Table 4-5, Table 4-6, and Table 4-7) were obtained through experiments specifically to determine the dissolution rates of the mineral. Also, all references come from peer-reviewed journals (AP-SIII-10Q, Section 5.2.1k, "reliability of data source") and provide data from experiments developed and carried out specifically to determine dissolution rates of minerals (AP-SIII-10Q, Section 5.2.1k, "extent to which the data demonstrates the properties of interest"). Therefore, they are considered appropriate and qualified for use in this model. 
Igneous Intrusion Impacts on Waste Packages and Waste Forms

Table 4-5. Dissolution Rates of Aluminosilicate Minerals

\begin{tabular}{|c|c|c|c|c|c|}
\hline \multicolumn{2}{|c|}{ Albite $^{\mathrm{a}}$} & \multicolumn{2}{|r|}{ Anorthite ${ }^{b}$} & \multicolumn{2}{|c|}{ Nepheline $^{c}$} \\
\hline $\mathrm{pH}$ & $\begin{array}{c}\log \text { DR } \\
\left(\mathrm{moles} / \mathrm{cm}^{2} \cdot \mathrm{s}\right)\end{array}$ & pH & Log DR (moles $\left./ \mathrm{cm}^{2} \cdot \mathrm{s}\right)$ & pH & DR (moles $\left./ \mathrm{m}^{2} \cdot \mathrm{s}\right)$ \\
\hline 1.2 & -14.25 & 3 & -13.3 & 3 & 4.03E-07 \\
\hline 2.1 & -14.60 & 3 & -13.9 & 5 & 4.00E-09 \\
\hline 2.5 & -14.86 & 3.1 & -13.0 & 7 & 2.07E-09 \\
\hline 2.95 & -15.26 & 3.25 & -13.5 & 11 & $1.28 E-08$ \\
\hline 3.05 & -15.18 & 3.5 & -14.3 & - & - \\
\hline 3.5 & -15.44 & 4 & -15.0 & 一 & - \\
\hline 4.1 & -15.50 & 4.5 & -15.2 & 一 & $=$ \\
\hline 5.1 & -15.82 & 5 & -15.5 & - & - \\
\hline 5.4 & -15.78 & 5.5 & -15.5 & $=$ & $=$ \\
\hline 5.5 & -15.68 & 5.5 & -15.6 & 二 & - \\
\hline 5.6 & -15.82 & 6 & -15.7 & - & - \\
\hline 5.6 & -15.92 & 6 & -15.0 & - & - \\
\hline 7.8 & -15.86 & 6 & -14.8 & 二 & - \\
\hline 8 & -15.70 & 6.5 & -15.7 & - & - \\
\hline 9.45 & -15.30 & 7 & -15.7 & - & - \\
\hline 9.55 & -15.22 & 7.25 & -15.6 & - & - \\
\hline 10 & -15.18 & 9.5 & -14.8 & - & $=$ \\
\hline 10 & -15.04 & 10 & -14.7 & - & - \\
\hline 10.7 & -15.00 & 12 & -14.2 & 二 & - \\
\hline 11.2 & -14.60 & - & - & - & - \\
\hline 11.6 & -14.64 & - & $=$ & $=$ & - \\
\hline 12.3 & -14.40 & 二 & - & - & - \\
\hline
\end{tabular}

Sources: ${ }^{a}$ Chou and Wollast 1985, Figure 5

${ }^{b}$ Brady and Waither 1989, Figure 4

${ }^{c}$ Tole et al. 1986, Table 2 (based on release of sodium)

NOTES: Due to lack of dissolution rates of sanidine, the rates for albite are used as a surrogate.

$\mathrm{DR}=$ dissolution rate. 
Table 4-6. Dissolution Rates of Olivine and Pyroxene Minerals

\begin{tabular}{|c|c|c|c|c|c|}
\hline \multicolumn{2}{|c|}{ Olivine $^{a}$} & \multicolumn{2}{|c|}{ Diopside $^{b}$} & \multicolumn{2}{|c|}{ Enstatite $^{c}$} \\
\hline pH & $\begin{array}{c}\log \text { DR } \\
\left(\mathrm{moles} / \mathrm{cm}^{2} \cdot \mathrm{s}\right)\end{array}$ & $\mathrm{pH}$ & $\begin{array}{c}\log D R \\
\left(\mathrm{moles} / \mathrm{cm}^{2} \cdot \mathrm{s}\right)\end{array}$ & pH & $\begin{array}{c}\log \text { DR } \\
\left(\mathrm{moles} / \mathrm{cm}^{2} \cdot \mathrm{s}\right)\end{array}$ \\
\hline 4.1 & -13.07 & 2.4 & -12.30 & 1 & -12.30 \\
\hline 5.7 & -13.78 & 3 & -12.60 & 2 & -13.00 \\
\hline 12 & -14.36 & 4 & -13.30 & 4 & -14.30 \\
\hline 10.4 & -14.74 & 4.5 & -13.90 & 6 & -15.15 \\
\hline 7.4 & -13.80 & 5 & -14.10 & 8.4 & -15.20 \\
\hline 9.9 & -14.46 & 5.6 & -14.50 & 9.4 & -14.95 \\
\hline 9.9 & -14.58 & 6 & -14.80 & 10.1 & -14.40 \\
\hline 9.9 & -14.38 & 6 & -14.90 & 12.2 & -13.60 \\
\hline 3.7 & -12.27 & 7.6 & -15.00 & - & - \\
\hline 10.8 & -15.27 & 9.4 & -15.20 & - & 一 \\
\hline 3 & -12.79 & 12.1 & -15.20 & - & - \\
\hline 5 & -12.73 & 1 & -13.50 & - & 二 \\
\hline 5.7 & -14.34 & 1.5 & -12.10 & - & 二 \\
\hline 2 & -11.99 & 2 & -12.20 & - & - \\
\hline 9.1 & -14.54 & 1 & -12.20 & - & $=$ \\
\hline 3.7 & -12.31 & - & - & - & - \\
\hline 2.5 & -12.21 & - & - & - & - \\
\hline 4.4 & -12.52 & - & - & - & - \\
\hline 3.1 & -12.34 & - & - & - & - \\
\hline 4 & -12.42 & - & - & - & - \\
\hline 3 & -12.29 & - & - & - & - \\
\hline 3.5 & -12.30 & - & 二 & - & - \\
\hline 3.1 & -11.88 & - & - & - & - \\
\hline 5.3 & -12.77 & - & - & - & - \\
\hline 10.8 & -14.27 & - & - & - & - \\
\hline
\end{tabular}

Sources: ${ }^{\mathrm{a}}$ Wogelius and Walther 1991, Table 2 (based on release of Mg)

${ }^{\mathrm{b}}$ Brantley and Chen 1995, Table 1 (Data are from rate studies by Schott and Knauss which can be found in Brantley and Chen (1995), which is a compilation of dissolution data from different sources)

${ }^{c}$ Brady and Walther 1989, Figure 5

NOTES: Due to lack of dissolution rates of hedenbergite, the rates for diopside are used as a surrogate. (See section 6.5.3)

Olivine rates used for both forsterite and fayalite.

$\mathrm{DR}=$ dissolution rate 
Table 4-7. Dissolution Rates of Hydroxylapatite, Magnetite, and IImenite

\begin{tabular}{|c|c|c|c|c|c|}
\hline \multicolumn{2}{|c|}{ Hydroxylapatite $^{a}$} & \multicolumn{2}{|c|}{ Magnetite $^{b}$} & \multicolumn{2}{|c|}{ IImenite ${ }^{b}$} \\
\hline $\mathrm{pH}$ & $\begin{array}{c}\text { DR } \\
\left(\text { moles } / \mathrm{m}^{2} \cdot \min \right)\end{array}$ & pH & $\begin{array}{c}\text { DR } \\
\left(\text { moles } / \mathrm{cm}^{2} \cdot \mathrm{s}\right)\end{array}$ & $\mathrm{pH}$ & $\begin{array}{c}\text { DR } \\
\left(\text { moles } / \mathrm{cm}^{2} \cdot \mathrm{s}\right)\end{array}$ \\
\hline 2.2 & $1.40 \mathrm{E}-07$ & $1.01-1.02$ & $1.31 \mathrm{E}-13$ & $1.15-1.21$ & $1.23 \mathrm{E}-13$ \\
\hline 2.8 & $6.00 \mathrm{E}-08$ & $1.00-1.01$ & $1.61 \mathrm{E}-13$ & $3.01-3.02$ & $2.51 E-14$ \\
\hline 2.9 & $4.00 \mathrm{E}-08$ & $2.01-2.07$ & $6.61 \mathrm{E}-14$ & $3.02-3.03$ & $1.09 E-14$ \\
\hline 6.5 & $3.20 \mathrm{E}-09$ & $2.95-3.10$ & $2.51 \mathrm{E}-14$ & $4.00-4.04$ & $8.10 \mathrm{E}-15$ \\
\hline 6.7 & 2.70E-09 & 2.98-3.05 & $3.71 E-14$ & $5.01-5.03$ & $3.40 \mathrm{E}-15$ \\
\hline - & 一 & $3.98-4.05$ & $2.51 \mathrm{E}-14$ & 6.01-6.05 & $5.00 \mathrm{E}-16$ \\
\hline - & 一 & $4.01-4.03$ & $3.10 \mathrm{E}-14$ & 二 & - \\
\hline - & - & 4.94-4.95 & 1.21E-14 & 一 & - \\
\hline - & 二 & $5.98-6.02$ & $1.02 E-14$ & - & - \\
\hline - & 一 & $6.67-7.03$ & 5.70E-15 & 一 & - \\
\hline
\end{tabular}

Sources: a Valsami-Jones et al., 1998, Table 2

b White et al., 1994, Table 2 (magnetite values for ISH magnetite. This study included 3 different magnetite specimens [ISH, MAR, and TAH magnetite, defined in White et al., 1994] of which ISH magnetite was the purest form)

NOTES: Rates used for magnetite and ilmenite are from anoxic tests. Since the Fe and Ti released by these minerals are quickly taken up into minerals and are not important to the aqueous parameters of interest, these rates are considered adequate for use.

Rates of hydroxylapatite dissolution are from tests using synthetic specimens. The synthetic specimens were used rather than the natural samples because rates for the synthetic samples covered a range of $5.5 \mathrm{pH}$ units (2.20-6.70) while the range for the natural samples covered only $1.25 \mathrm{pH}$ units (3.95-5.20). Also, 5 synthetic samples were tested at various $\mathrm{pH}$ values, whereas there were only two data points for the natural samples. The synthetic samples were used since the data cover a larger range of possible conditions.

$\mathrm{DR}=$ dissolution rate.

\subsubsection{Composition and Flow Rate of Incoming Water}

The composition of the water flowing through the basalt in Zone 1 (Table 4-8) is taken as that resembling Bin 8 seepage water from DTN: MO0310SPAEBSCB.003. Since the EQ6 simulations of water/basalt interaction were carried out at $25^{\circ} \mathrm{C}$, Bin 8 (at $40.18^{\circ} \mathrm{C}$ ) was chosen as all other water types were for higher temperatures. Sensitivity of results to groundwater composition is investigated in section 6.5.3.2. The water composition parameters and their values for Bin 8 seepage water (DTN: MO0310SPAEBSCB.003) are given in Table 4-8. 
Table 4-8. Water Composition and Redox Conditions Used in EQ3

\begin{tabular}{|l|c|l|}
\hline \multicolumn{3}{|c|}{ EQ3NR Input Composition Values } \\
\hline \multicolumn{1}{|c|}{ Element } & Concentration & \multicolumn{1}{c|}{ Units } \\
\hline $\mathrm{Na}^{+}$ & $7.31 \mathrm{E}-03$ & moles $/ \mathrm{kg}$ \\
\hline $\mathrm{SiO}_{2}$ (aq) & $1.79 \mathrm{E}-03$ & moles $/ \mathrm{kg}$ \\
\hline $\mathrm{Ca}^{++}$ & $5.73 \mathrm{E}-04$ & moles $/ \mathrm{kg}$ \\
\hline $\mathrm{K}^{+}$ & $2.76 \mathrm{E}-04$ & moles $/ \mathrm{kg}$ \\
\hline $\mathrm{Mg}^{++}$ & $8.51 \mathrm{E}-05$ & moles $/ \mathrm{kg}$ \\
\hline $\mathrm{H}^{+}$ & 7.94 & $\mathrm{pH}$ \\
\hline $\mathrm{F}^{-}$ & $6.43 \mathrm{E}-04$ & moles $/ \mathrm{kg}$ \\
\hline $\mathrm{Cl}^{-}$ & $5.61 \mathrm{E}-04$ & moles $/ \mathrm{kg}$ \\
\hline $\mathrm{NO}_{3}^{-}$ & $3.97 \mathrm{E}-05$ & moles $/ \mathrm{kg}$ \\
\hline $\mathrm{SO}_{4}^{-}$ & $3.55 \mathrm{E}-04$ & moles $/ \mathrm{kg}$ \\
\hline $\mathrm{AlO}_{2}$ & $1.50 \mathrm{E}-09$ & moles $/ \mathrm{kg}$ \\
\hline $\mathrm{HFeO}_{2}$ (aq) & $1.49 \mathrm{E}-12$ & moles $/ \mathrm{kg}$ \\
\hline
\end{tabular}

DTN:MO0310SPAEBSCB.003, Temperature $=40^{\circ} \mathrm{C}$

A total of 6 cases of basalt/water interaction were run for each $\mathrm{CO}_{2}$ fugacity. These cases involved a base case in which the flux is $0.4 \mathrm{~mm} /$ year, all mineral surfaces are available for reaction, saturation of 0.12 , basalt is fractured in meter sized blocks, and a pore fraction of 0.17 . The other 5 cases involve changing base-case parameters as shown in Table 4-9.

Saturation values chosen are 0.12 (lowest saturation) and 1.0 (highest saturation). These two values bound the range of possible saturation values. The base case flux rate of $0.4 \mathrm{~mm} /$ year represents the lower-bound climate scenario flux for the repository area which is used in TSPA (BSC 2004 [DIRS:168848], Table 6.4-1). Percolation fluxes of 3.8 and 11.7 from the mean climate scenario were also used to incorporated differences in percolation flux into the abstraction. Higher values of percolation flux $(25,50$, and $100 \mathrm{~mm} /$ year $)$ were used solely for determining the flux where groundwater was unaffected by reaction with basalt and are not part of the abstraction (Section 6.5.3.1).

Table 4-9. Parameter and Values Changes for Abstraction Cases for BasaltWater Interaction

\begin{tabular}{|c|c|c|}
\hline Parameter & Base Case Value & Changed Value \\
\hline \multirow{2}{*}{ Flux (mm/year) ${ }^{a}$} & \multirow{2}{*}{$0.4 \mathrm{~mm} /$ year } & $3.8 \mathrm{~mm} /$ year \\
\hline & & $11.7 \mathrm{~mm} /$ year \\
\hline Saturation $^{\mathrm{b}}$ & 0.12 & 1.0 \\
\hline Pore Fraction $^{c}$ & 0.17 & 0.13 \\
\hline Surface Area of Minerals ${ }^{d}$ & $\begin{array}{c}\begin{array}{c}\text { Values in Table } 6-4 \text { of this } \\
\text { report }\end{array} \\
\end{array}$ & $\begin{array}{c}0.1 \text { times values in Table } \\
6.4\end{array}$ \\
\hline \multicolumn{3}{|c|}{ 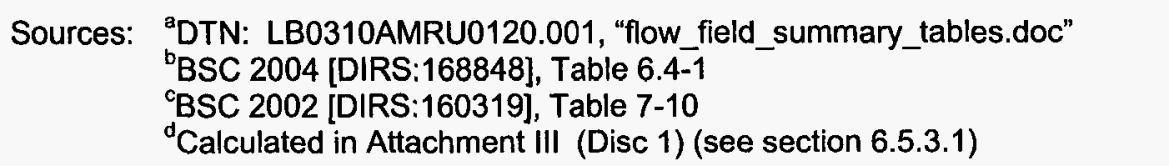 } \\
\hline
\end{tabular}




\subsubsection{Sensitivity Cases}

Two sensitivity cases look at the effect that different water compositions have on the chemistry of the basalt/water interaction. The composition of the two modeled water types are presented below in Table 4-10. EQ3NR output for input into EQ6 is listed in Table 6-6.

Table 4-10. Water Composition and Redox Conditions Used in the EQ3 for Sensitivity Cases

\begin{tabular}{|l|c|c|c|c|}
\hline \multicolumn{5}{|c|}{ EQ3NR Input Composition Values } \\
\hline \multirow{2}{*}{ Species } & \multicolumn{2}{|c|}{ Bin 11 Seepage Water ${ }^{\mathrm{a}}$} & \multicolumn{2}{c|}{$\mathrm{J}-13$ Well Water } \\
\cline { 2 - 5 } & Concentration & Units & Concentration & Units \\
\hline $\mathrm{Na}^{+}$ & $4.80 \mathrm{E}-03$ & moles $/ \mathrm{kg}$ & 45.8 & $\mathrm{mg} / \mathrm{L}$ \\
\hline $\mathrm{SiO}_{2}$ (aq) & $1.19 \mathrm{E}-02$ & moles $/ \mathrm{kg}$ & $28.5^{\mathrm{c}}$ & $\mathrm{mg} / \mathrm{L}$ \\
\hline $\mathrm{Ca}^{++}$ & $3.34 \mathrm{E}-04$ & moles $/ \mathrm{kg}$ & 13.0 & $\mathrm{mg} / \mathrm{L}$ \\
\hline $\mathrm{K}^{+}$ & $7.50 \mathrm{E}-04$ & moles $/ \mathrm{kg}$ & 5.04 & $\mathrm{mg} / \mathrm{L}$ \\
\hline $\mathrm{Mg}^{++}$ & $6.34 \mathrm{E}-06$ & $\mathrm{moles} / \mathrm{kg}$ & 2.01 & $\mathrm{mg} / \mathrm{L}$ \\
\hline $\mathrm{H}^{+}$ & 7.759 & $\mathrm{pH}$ & 7.41 & $\mathrm{pH}$ \\
\hline $\mathrm{F}^{-}$ & $1.38 \mathrm{E}-03$ & $\mathrm{moles} / \mathrm{kg}$ & 2.18 & $\mathrm{mg} / \mathrm{L}$ \\
\hline $\mathrm{Cl}^{-}$ & $1.30 \mathrm{E}-03$ & moles $/ \mathrm{kg}$ & 7.14 & $\mathrm{mg} / \mathrm{L}$ \\
\hline $\mathrm{NO}_{3}^{-}$ & $1.26 \mathrm{E}-04$ & moles $/ \mathrm{kg}$ & 8.78 & $\mathrm{mg} / \mathrm{L}$ \\
\hline $\mathrm{SO}_{4}^{-}$ & $7.29 \mathrm{E}-04$ & moles $/ \mathrm{kg}$ & 18.4 & $\mathrm{mg} / \mathrm{L}$ \\
\hline $\mathrm{AlO}_{2}$ & $1.42 \mathrm{E}-09$ & moles $/ \mathrm{kg}$ & - & - \\
\hline $\mathrm{HFeO}_{2}$ (aq) & $2.08 \mathrm{E}-12$ & moles $/ \mathrm{kg}$ & - & - \\
\hline $\mathrm{Temperature}^{-}$ & 95.6 & ${ }^{\circ} \mathrm{C}$ & 25 & ${ }^{\circ} \mathrm{C}$ \\
\hline
\end{tabular}

NOTES: ${ }^{\text {a }}$ DTN: MO0310SPAEBSCB.003

${ }^{\circ}$ DTN: MO0006J13WTRCM.000

${ }^{\mathrm{C}}$ Value is for $\mathrm{Si}$ instead of $\mathrm{SiO}_{2}$

\subsubsection{General EQ6 Inputs That Apply to All EQ6 Cases in This Model}

\subsection{Thermodynamic Database}

The thermodynamic database used for the EQ6 calculations was the "data0.slt" file used at $25^{\circ} \mathrm{C}$, which is the qualified database ("data0.ymp.R2," DTN: MO0302SPATHDYN.000), but with commercial spent nuclear fuel and Savannah River Laboratory Glass included as "Minerals" and with 34 gas species deleted. The changes made to the database were not made specifically for this report, but for general use in EQ6 calculations of waste package corrosion. The reason for deleting 34 gas species is that the EQ6 constraints only accommodate a limited number of gas species to be read from the database and the deleted gas species are not required for these types of calculations. The database can be found on Attachment III (Disc 1). The "data0.ymp.R2" database is used in this model as it is the most comprehensive database available for modeling of aqueous systems. 


\subsection{Atomic Weights}

Atomic weights used in the model calculations come from handbook data sources (Atomic Mass Adjustment, Mass List for Analysis (Audi and Wapstra 1995) and Nuclides and Isotopes, Chart of the Nuclides (Parrington et al. 1996)) and are considered appropriate for use in the model.

\subsection{CRITERIA}

Project Requirements Document (Canori and Leitner 2003) identifies the high-level requirements for the Yucca Mountain Project. The requirements that pertain to this modeling report, and their link to 10 CFR Part 63, are shown below.

1. PRD-002/T-014 (page 3-14) Performance Objectives for the Geologic Repository After Permanent Closure (Regulation 10 CFR 63.113):

This section specifies the repository performance objectives that must be met following permanent closure. It includes a requirement for multiple barriers and limits on radiological exposure.

2. PRD-002/T-015 (page 3-14) Requirements for Performance Assessment (Regulation 10 CFR 63.114):

This section specifies the technical requirements to be used in performing a performance assessment. It includes requirements for calculations, including data related to site geology, hydrology, and variability in the models, and deterioration or degradation processes, including waste form degradation.

The following acceptance criteria from Yucca Mountain Review Plan, Final Report (NRC 2003) were identified as applicable to this technical product. Section 8.4 identifies information in this report that addresses the acceptance criteria associated with the integrated sub-issue of Mechanical Disruption of Engineered Barriers.

Mechanical Disruption of Engineered Barriers Acceptance Criteria (NRC 2003, Section 2.2.1.3.2.3):

- Acceptance Criterion 1: System description and model integration are adequate.

- Acceptance Criterion 2: Data are sufficient for model justification.

- Acceptance Criterion 3: Data uncertainty is characterized and propagated through the model abstraction.

- Acceptance Criterion 4: Model uncertainty is characterized and propagated through the model abstraction.

- Acceptance Criterion 5: Model abstraction output is supported by objective comparisons. 


\subsection{CODES AND STANDARDS}

None

\section{ASSUMPTIONS}

This section identifies relevant assumptions, along with their respective rationale, that are essential for process modeling and assessing the impacts of igneous intrusion on waste packages and waste forms.

\subsection{Permeability of Metamorphic Aureole and Cooled Basalt}

Assumption: The permeability of any contact metamorphic aureole surrounding the intruded drifts is assumed to be as great as that of the bulk host rock. The basalt is assumed to fracture during cooling so that it too provides no barrier to flow.

Rationale: Natural analogs indicate that a number of different processes could lower permeabilities in the host rock immediately in contact with an intrusion (Lichner et al. 1999, pages 8 and 9, and Frankel, 1967). However, the extent or uniformity of any changes to the host rock caused by the intrusion is not known. Therefore, it is assumed that hydraulic properties of the aureole are the same as those of the host rock.

In the case of the intrusive, the basalt would crack during magma cooling and degassing, providing paths for water flow. Maximum fracturing would occur at the flow margins resulting in greater permeability at the margins than in the center of the flow. However, the amount of fracturing that would occur and the resulting permeability variation is unknown so it is assumed that fracturing is uniform throughout the flow. It is further assumed that the fracturing is extensive enough that the basalt provides no barrier to flow such that it is the same as the host rock.

Confirmation Status: This assumption is conservative because it permits maximum water flow through the basalt-filled drifts. Since the assumption is not used to limit flow of water through the basalt, confirmation is not required.

Use in the Model: This assumption is used in Sections 6.4.3 and 6.5.3..

\subsection{Fracturing of Basalt and Block Size}

Assumption: It is assumed that basalt will fragment into meter sized blocks.

Rationale: Joints in basaltic rocks can vary in size from $\mathrm{cm}$ to meter scale blocks. As an example, in common thin flows of the Hawaiian volcanoes which cool relatively quickly, most blocks are 0.5 meters across or smaller. However in thicker flows where the magma has slowly cooled, blocks are much larger. In several areas where flows remained thick due to confinement in valleys, blocks 10 or more feet across were noted (Macdonald, 1967). Hearn et al. (1985, Page 8) report blocks approximately 3 feet in diameter in the slowly cooled interior portion of flows from the Columbia Plateau while the quickly cooled margins show much smaller columns.. In 
many parts of the world, thick basalt lava flows have well developed joints. Jointing is not solely restricted to surface basaltic flows. Many intrusive bodies also show well developed joints. Dikes 1 meter thick are known to be broken into irregular columns (Macdonald, 1967). Joints develop progressively as the magma cools and, as shown above, size and shape are related to rate of cooling (larger flows whose interiors cool much more slowly than thin flows have larger joint blocks). The margins of the potential dike intrusion will likely cool quickly due to a chilling effect caused by the cooler drift walls. However, the interior of the magma (as shown in Section 6.5.2) cools relatively slowly, taking several months to solidify. Therefore, the fractures/joints that form in the basalt are expected to be large (meter scale). One meter size blocks were chosen for the base case scenario. Larger block sizes would effectually cause a decrease in the available reactive surface area in contact with water percolating through the basalt. One case in the abstraction looks at the effects of decreased surface area on the water chemistry. Therefore, the affect caused by even larger blocks has also been taken into account in the abstraction

Confirmation Status: Using the meter sized blocks is considered realistic. Therefore, no further confirmation needed.

Use in the Model: This assumption is used in Section 6.5.3.1.

\subsection{Thermal Properties of the Magma}

Assumption: It is assumed that thermal conductivity and thermal diffusivity of the magma are the same as the welded tuff.

Rationale: The exact properties of the magma that could intrude into the emplacement drift(s) are unknown. The assumption that the thermal properties (thermal conductivity and diffusivity) of the in-drift magma is the same as the drift wall rocks is reasonable for this type of order of magnitude analysis. In addition, the sensitivity of these parameters was examined in the uncertainty section (Section 6.6.1), and it was determined that the resulting peak temperature is not sensitive to this parameter.

Confirmation Status: Attachment I shows that the results are not sensitive to these parameters. Therefore, no further confirmation is needed.

Use in the Model: This assumption is used in Section 6.5.2.1.

\subsection{Exsolved Volcanic Gas Movement from Zone 1 to Zone 2 Emplacement Drifts Due to Dike Intrusion}

Assumption: It is assumed that, due to reactions with pore fluids and the tuff host rocks of the repository horizon as well as decreasing pressures, corrosive gases released during a dike intrusion will not reach Zone 2 emplacement drifts in quantities able to affect corrosion resistance of materials.

Rationale: The flow of air, $\mathrm{H}_{2} \mathrm{O}, \mathrm{SO}_{2}$, and $\mathrm{CO}_{2}$ between Zone 1 and Zone 2 emplacement drifts is analyzed in Dike/Drift Interactions (BSC 2003 [DIRS: 165923]). The model report concludes that several processes impede the movement of gases toward Zone 2 drifts. The boiling zone created within the intruded drift limits the migration of gases. As well as the dissolution of gases into the aqueous phase, the gases would diffuse back into the rock matrix after gas pressure from 
the intrusion subside. Gases flowing through the coarse backfill in perimeter drifts would be diluted by air. Crushed tuff material and water content would also retard gas movement. In addition, oxidation/reduction reactions involving sulfur species would further retard gas migration.

Characterize Eruptive Processes at Yucca Mountain, Nevada (BSC 2003 [DIRS:166407]) recommends a composition of volatile gases in mole percent. BSC 2003 [DIRS: 165923] shows that the gases that compose the majority of the exsolved gases $\left(\mathrm{H}_{2} \mathrm{O}, \mathrm{CO}_{2}\right.$, and $\left.\mathrm{SO}_{2}\right)$ are significantly retarded so that they have no effect on Zone 2 emplacement drifts. It is therefore reasonable to assume that other reactive gases such as $\mathrm{HF}$ and $\mathrm{HCl}$, which are present in minor quantities in the gas front (0.87 and 0.17 mole percent respectively, BSC 2003 [DIRS:166407]), are also retarded through reaction with the tuff host rock and water.

Confirmation Status: Needs further confirmation through analysis.

Use in the Model: This assumption is used in Section 6.5.2.2.

\section{MODEL DISCUSSION}

\subsection{MODELING OBJECTIVES}

The main objective of this model is to assess many of the potential impacts of igneous intrusion on waste packages and waste forms in the emplacement drifts at the Yucca Mountain Repository. The model is based on conceptual models and includes an assessment of deleterious dynamic, thermal, hydrologic, and chemical conditions.

The TSPA-LA approach to implementing the models for waste package and waste form response during igneous intrusion is based on identification of damage zones. Zone 1 includes all emplacement drifts intruded by the basalt dike, and Zone 2 includes all other emplacement drifts in the repository that are not in Zone 1. This model report will document the following model assessments for implementation into TSPA damage zones as:

- Mechanical and thermal impacts of basalt magma intrusion on the invert, waste packages and waste forms of the intersected emplacement drifts of Zone 1.

- Temperature and pressure trends of basaltic magma intrusion intersecting Zone 1 and their potential effects on waste packages and waste forms in Zone 2 emplacement drifts.

- Deleterious volatile gases exsolving from the intruded basalt magma, and their potential effects on waste packages of Zone 2 emplacement drifts.

- Post-intrusive physical-chemical environment and seepage water alteration by reaction with intruded basalt in Zone 1.

The scope of this model only includes impacts to the components stated above, and does not include impacts to other engineered barrier system (EBS) components such as the waste package pallet. 
The results of this model report will be used in TSPA for several parameters including 1) temperature of magma (used for the temperature of the fuel after an intrusion), 2) amount of temperature increase in Zone 2 due to intrusion to evaluate impact to Zone 2 waste packages, 3) effects of exsolved gases reaching Zone 2 (to evaluate impact to Zone 2 waste packages), and 4) $\mathrm{pH}$ and ionic strength of water reacted with basalt (to be used in conjunction with Dissolved Concentration Limits of Radioactive Elements BSC 2003 [DIRS:163152]) to determine solubility of spent fuel within the basalt. Ionic strength will also be used in conjunction with Waste Form and In-Drift Colloids-Associated Radionuclide Concentrations: Abstraction and Summary (BSC 2003 [DIRS:166845]) for stability of colloids after intrusion.

Consequences of igneous activity to the Yucca Mountain Repository are evaluated in TSPA-LA models for the eruptive (volcanic eruption intersecting repository causing direct release of radioactive waste) and igneous-intrusion groundwater-transport modeling cases (damage to waste packages that are engulfed or otherwise affected by igneous intrusion) (BSC 2003 [DIRS 166296]). This model report explicitly supports the igneous-intrusion groundwater-transport modeling case (BSC 2003 [DIRS 166296]) by providing impacts to waste packages and waste forms due to igneous intrusion and changes in groundwater chemistry caused by water percolating through a basalt filled drift. Other features of an igneous event are captured in other model reports. Characterize Eruptive Processes at Yucca Mountain, Nevada (BSC 2003 [DIRS:166407]) provides information about natural volcanic systems and provides parameters that can be used to model their behavior. Parameters provided are appropriate for analysis of the consequences of volcanic eruptions at Yucca Mountain. Number of Waste Packages Hit by Igneous Intrusion (BSC 2004 [DIRS:164650) calculates the number of waste packages that could be damaged in a potential future igneous disruption . Dike/Drift Interactions (BSC 2003 [DIRS:165923]) provides an analysis of the intersection of ascending magma with repository drifts including a discussion on dike propagation, magma flow, and gas flow and conductive cooling of a magma cooled drift. Atmospheric Dispersal and Deposition of Tephra from a potential Volcanic Eruption at Yucca Mountain (BSC 2004 [DIRS:167616]) (referred to as ASHPLUME) provides information on the redistribution of contaminated tephra from a potential volcanic eruption for the prediction of radioactive waste/ash deposition on the ground surface.

The objectives of the model assessments are realized through model simulations, sensitivity analyses, and corroboration with relevant natural and industrial analogs or published data. These assessments and their results and limitations are provided in Sections 6.5, 6.6, 6.7, 7, and 8 .

\subsection{INCLUDED FEATURES, EVENTS AND PROCESSES}

In support of TSPA-LA, one feature, event, or process (FEP) is considered (FEP 1.2.04.04.0A, Interaction of igneous intrusion with engineered barrier system components). The disposition of this FEP is summarized in Table 6-1. 
Igneous Intrusion Impacts on Waste Packages and Waste Forms

Table 6-1. Included FEP for This Model Report and Its Disposition in TSPA-LA

\begin{tabular}{|l|l|l|}
\hline FEP Number & \multicolumn{1}{|c|}{ License Application FEP Title } & Section Where Disposition is Described \\
\hline 1.2.04.04.0A & Igneous intrusion interacts with EBS components & $\begin{array}{l}\text { Sections 6.5.1, 6.5.2, and 6.7 } \\
\text { Attachment I }\end{array}$ \\
\hline
\end{tabular}

Description: An igneous intrusion in the form of a dike occurs through the repository, intersecting the repository drifts. Magma, pyroclastics, and volcanic gases enter the drift and interact with the EBS components including the drip shields, the waste packages, pedestal, and invert. This leads to accelerated drip shield and waste package failure (e.g. attack by magmatic volatiles, damage by flowing or fragmented magma, thermal effects) and dissolution or volatilization of waste. (DTN: MO0307SEPFEPS4.000)

Summary of Disposition in TSPA-LA:

The effects of an igneous intrusion into the repository are implemented in the TSPA through the delineation of two zones. Zone 1 encompasses portions of the drifts where EBS components are directly contacted by magma. Zone 2 encompasses the remainder of the drifts, where EBS components are not contacted by magma, but are exposed to thermal effects and magmatic gases. A summary of the effects of igneous intrusion on EBS components is presented here.

Section 6.5.1 indicates the igneous intrusion would render the drip shields, waste packages and cladding in the Zone 1 emplacement drifts ineffective so they would provide no further protection to the waste. Also, waste package materials would be distributed throughout the cooled magma, though exactly how is unknown. Spent fuel is itself a refractory material and is considered to be chemically unaffected by exposure to the intruding magma. Likewise, waste glass degradation behavior is considered likely to be minimally affected by consequent devitrification (BSC 2004 [DIRS:167619], Section 7.5.4). As the waste packages/waste forms will be distributed throughout the magma body, then the temperature of those waste forms can be considered the same as the temperature of the cooling magma. These values are presented in DTN: MO0402SPAHWCIG.002.

The impacts of magmatic heat conduction from Zone 1 to Zone 2 emplacement drifts were modeled by numerical simulations of Non-Steady State heat conduction with radial flow in Section 6.5.2.1 and Attachment I. The simulation modeling of heat conduction away from the intruded drifts demonstrates that the initial $1150^{\circ} \mathrm{C}$ temperature reduces to about $30^{\circ} \mathrm{C}$ at the center of the drift in about 30 years, and the maximum temperature rise expected in the Zone 2 emplacement drifts is less than $1^{\circ} \mathrm{C}$. Model results show that the rock separating drifts limits flow of heat from magma-filled drift. No thermal impacts from Magma-filled drifts are expected for waste packages, drip shields, or cladding in Zone 2 emplacement drifts.

The information about gas flow from Zone 1 to Zone 2 emplacement drifts comes from BSC 2003 [DIRS:165923] This report shows that due to reactions and decreasing pressures, $\mathrm{H}_{2} \mathrm{O}, \mathrm{SO}_{2}$ and $\mathrm{CO}_{2}$ released from the intrusion event will not reach Zone 2 in sufficient quantities to affect waste packages and waste forms in Zone 2 emplacement drifts. Affects of other corrosive gases is discussed in Section 5.4 and 6.5.2.2.

After post-intrusive magma cooling and reversion to normal in-drift environmental conditions, seepage water percolating through the intruded basalt will be chemically altered by reaction with basaltic minerals. As shown in Section 6.7.2 of this model report, this alteration involves significant changes to the $\mathrm{pH}$ and ionic strength of the solution. The $\mathrm{pH}$ and $\mathrm{fCO}_{2}$ values obtained through reaction of seepage water with basalt should be used in conjunction with Dissolved Concentration Limits of Radioactive Elements (BSC, 2003 [DIRS:163152]) to describe the solubility of the waste forms. Because waste forms are considered chemically unchanged (Section 6.5.1.2), the dissolved concentration of radioelements in water would have the same dependency on water chemistry in regions influenced by an igneous intrusion as radionuclides in those regions that are not. Thus, the solubility tables given in Dissolved Concentration Limits of Radioactive Elements (BSC 2003 [DIRS: 163152]) should be used to determine concentrations of radionuclides in basalt-filled drifts the same way they are used in the nominal case.

\subsection{BASE-CASE CONCEPTUAL MODEL}

The base-case conceptual model is based on the igneous intrusion and associated processes; these are outlined in the following:

- A basaltic magma dike intrudes into Zone 1 emplacement drifts. Once inside the drift, the magma flows over the invert leaving it essentially intact.

- Hot magma fills the drift. Materials become surrounded by magma intruded into Zone 1 drifts. 
- Post-intrusive perturbations occur to the in-drift environment due to magma cooling. These perturbations include heat loss by conduction, degassing, and fracturing of the intrusive body. During the post-intrusive perturbations, the magma would cool and the deleterious volatile gases, exsolving from the intruded magma, would diffuse through the host rock (tuff) toward Zone 2 emplacement drifts.

- The in-drift environment reverts to normal conditions, with re-establishment of seepage flow. Seepage water entering the intruded drifts would react and equilibrate with the cooled and fractured basalt.

\subsection{ALTERNATE CONCEPTUAL MODELS}

The model that serves as the base-case for this model report is necessarily very simple because of the lack of detailed information about the precise conditions that are most likely to prevail given the occurrence of an igneous intrusion event.

Alternatives that may be relevant for igneous intrusive event impacts on the waste packages and waste forms are discussed in the remainder of Section 6.4 .

\subsubsection{Reaction Between Waste Forms, Metals, and Basalt}

The base case model does not consider the effects of reactions between the waste forms and the basalt and its reactive exudates. The spent fuel within the commercial fuel rods is a ceramic material with a high melting point temperature with a range of approximately $2600^{\circ} \mathrm{C}$ (Todreas and Kazimi 1990, Page 307 for LWR fuels) to $2800^{\circ} \mathrm{C}$ (Lide 2002, Page 4-92 for $\mathrm{UO}_{2}$ ). Therefore, the commercial spent nuclear fuel exposed to hot magma is not expected to melt at temperatures up to the maximum magma temperature of $1169^{\circ} \mathrm{C}$ (BSC 2003 [DIRS:166407], Table 8). However, when the waste canisters/assemblies and fuel claddings are damaged, the fuel pellets/rods may be assimilated into cooling basalt magma. Under this scenario, two types of processes are expected: chemical interaction between waste forms and the magma and chemical interaction between the waste forms and the metal of waste canisters/assemblies and cladding in the presence of hot magma.

In the first case, oxidation of $\mathrm{UO}_{2}$ fuel in the presence of water-rich volatiles exsolving from cooling basalt magma may occur (Einziger et al. 1991). In addition, radionuclides in the waste could be incorporated into crystallizing silicate mineral phases such as soddyite $\left[\left(\mathrm{UO}_{2}\right)_{2}\left(\mathrm{SiO}_{4}\right) \times\right.$ $2 \mathrm{H}_{2} \mathrm{O}$ ]. Fission products (Cs, Tc, etc) may also be incorporated into new mineral phases. Silicate phases may have some of these cations loosely incorporated making them more soluble in postcooling groundwater. However, it is unknown which phases and mineral structures are more likely to form.

In the second case, chemical interactions may occur between fuel and metals/alloys of damaged waste canisters/assemblies and claddings in the presence of the cooling magma that may result in the formation of new phases. This type of interaction is demonstrated by experiments conducted between $\mathrm{UO}_{2}$ and Zircaloy-4 under isothermal and transient temperatures of 1000 to $1700^{\circ} \mathrm{C}$ and at 1 to 80 bars pressures for a duration of 1-150 minutes (Hofmann and Kerwin-Peck 1984). The authors show that under reducing conditions, oxygen from $\mathrm{UO}_{2}$ is transported to the Zircaloy via the gas phase, and as a result, uranium metal is formed. Uranium then diffuses to react with 
zirconium to form a layer of $\mathrm{U}-\mathrm{Zr}$ alloy at about $800^{\circ} \mathrm{C}-1150^{\circ} \mathrm{C}$. Subsequently, several other solid solution layers of interactive $\mathrm{U}-\mathrm{Zr}$ and $\mathrm{Zr}$-oxides are formed at lower temperatures.

It is expected that mineral phases would result from interaction between waste, waste package materials, and magma, but the compositions of such phases and their properties are not known. Since development of mineral phases would tend to limit subsequent reactivity of the altered waste forms, no further analysis of this alternative conceptual model has been done.

\subsubsection{Reaction Between Corrosion Products, Metals, and Basalt}

Igneous intrusion could effect chemical reactions within the waste packages and the drift. As magma intrudes into the drift, it compromises the integrity of the waste packages and could enable a "thermite-type reaction" between aluminum and iron oxide (from corrosion of waste package components) by the following reaction:

$$
2 \mathrm{Al}(\mathrm{s})+\mathrm{Fe}_{2} \mathrm{O}_{3}(\mathrm{~s}) \rightarrow \mathrm{Al}_{2} \mathrm{O}_{3}(\mathrm{~s})+2 \mathrm{Fe}(\mathrm{l})
$$

These types of reactions are extremely exothermic and the activation energy required for this reaction to proceed could be provided by the temperature increase in the drift from intruded magma. The $\Delta \mathrm{H}^{\circ}{ }_{\mathrm{rxn}}$ (heat of reaction) is about $-847.6 \mathrm{~kJ} / \mathrm{mole}$, and the temperatures from this reaction can exceed $1500^{\circ} \mathrm{C}$, producing molten iron. However, there are several conditions that make occurrence of this type of reactions less likely:

- A requirement for this reaction is direct contact between iron oxides and aluminum. If during magma intrusion (magma acts as a continuous medium), iron oxide and aluminum were to come into contact with each other and the magma, they would likely react with the magma components to form secondary phases. In a study of ferritic stainless steels exposed to basaltic magma at a temperature of $1150^{\circ} \mathrm{C}$ (Douglass 1983), a $\mathrm{Cr}_{2} \mathrm{O}_{3}$ scale formed on the outer surface of the metals, while internally sulfidation and oxidation occurred in the low $\mathrm{Cr}$ steel. Furthermore, Fe dissolved in the magma reacted with the surface scale to create spinels. Ehrlich and Douglass (1982) indicate that lower alloy steels form a surface scale of both $\mathrm{FeS}$ and $\mathrm{MoO}_{2}$. Crystals within the sulfideoxide grain boundary network within the iron were a silicate of the type $(\mathrm{Mg}, \mathrm{Ca}, \mathrm{Fe})_{2} \mathrm{Si}_{2} \mathrm{O}_{6}$, believed to be a clinopyroxene. It is therefore reasonable that reaction would also occur between basaltic magma, carbon steel, aluminum, and oxides.

- Both aluminum and carbon steel degrade very quickly (McCright, 1998 and Hollingsworth and Hunsicker, 1987) to form aluminum oxides and iron oxides. Therefore it is highly unlikely that unoxidized/non-corroded aluminum would be in contact with iron oxides inside waste packages.

If any of the components to the thermite reaction are missing (i.e., unoxidized/non-corroded aluminum and iron oxides), the thermite reaction will not occur. Because these materials will easily be incorporated into the magma or into secondary phases, the likelihood of having the unaltered aluminum and iron oxides in contact is very small. Therefore, this alternative conceptual model is not analyzed further in this model. 


\subsubsection{Permeability of Contact Metamorphic Aureole}

During the intrusive and magma-cooling periods, propagation of dynamic pressures, fluid flow, conduction of heat and diffusion of volatile gases from Zone 1 drifts could induce a perturbed physical, thermal and chemical environment between Zones 1 and 2. Among the expected perturbations is the formation of a contact metamorphic aureole. Magma fluids at high temperatures would interact with the drift wall rock (tuff), modifying the rock mineralogical composition, reducing the permeability and porosity of the contacted tuff. Natural analogs also indicate that at the contacts of basalt dikes with tuffs of the types found at Yucca Mountain there is fusion and devitrification of glass to clays (Lichtner et al. 1999, pp. 8 and 9). Because the extent and uniformity of the aureole is not known, the base case model makes the conservative assumption that the hydraulic properties of the host rock remain the same after intrusion. (see Section 5.1).

\subsubsection{Fragmentation of Waste Forms}

The data presented in Attachment I of Miscellaneous Waste-Form FEPs (CRWMS M\&O 2001) presents the distribution of different size fractions of ground (ground by mortar and pestle in the laboratory) $\mathrm{UO}_{2}$ fuel including unaltered fuel (uncorroded and unoxidized), dry-air oxidized fuel, and aqueous corroded fuel. The TSPA-LA eruptive model requires a fine particle size distribution ranging from 0.0001 to $0.05 \mathrm{~cm}$ to implement transport calculations within the ASHPLUME model (BSC 2004 [DIRS 167616]. The distribution is assumed for use in a mathematical construct, an incorporation ratio, used in the ASHPLUME model to abstract airborne transport of the fuel as attached to ash particles. Consequently, the following discussion is not relevant to the igneous intrusion model and is discussed only to address alternative models.

The technical basis for the waste fuel particle size distribution used in the eruptive model is based on laboratory data. UO2 fuel in various forms was purposely pulverized by mortar and pestle in the laboratory for a corrosion experiment (CRWMS M\&O 2001 [DIRS 153938], Attachment I). After the UO2 fuel was crushed initially, it was noted that there were numerous large fragments $(>0.015 \mathrm{~cm})$, material less than $0.0045 \mathrm{~cm}$ and a relatively small amount of particles between 0.0045 and $0.015 \mathrm{~cm}$. Larger pieces were re-ground and the materials milled again. The final mean diameter of particles ranged from 0.002 to $0.0002 \mathrm{~cm}$. It is reemphasized that the resulting particle size distribution is used solely to implement the ASHPLUME model. The particle distribution is not intended to represent actual fragmentation expected from a pyroclastic eruption or an effusive igneous intrusion.

\subsection{BASE-CASE CONCEPTUAL MODEL RESULTS}

For assessing the impacts of igneous intrusion, a conservative approach is taken by considering sequential events and processes during the intrusive and post-intrusive periods. (Given the nature of the intrusive event and processes, the modeling and assessment of impacts are governed by aleatoric and epistemic uncertainties. Aleatoric uncertainty refers to uncertainty for which sufficient knowledge is unobtainable such that the corresponding parameters are treated as chance of occurrences of FEPs. Epistemic uncertainty arises from a lack of knowledge about a parameter because the data are limited or there are alternative interpretations of the available data. A discussion of these uncertainties is presented in Section 6.6.) To compensate for 
uncertainties, a conservative approach is taken in the modeling of and assessing the impacts of igneous intrusion. Expected conditions such as intrusive temperature, pressure, flow velocity and volume, and total compression of waste packages, cladding and waste forms (see Section 5) have been bounded. In addition, the results of this study are corroborated by relevant natural and industrial analog and experimental data. As noted in Section 1, this MR is intended to support the igneous intrusion groundwater model (BSC 2003 [DIRS 166296]).

A summary of input data and parameters used in the model and related analyses are presented in Table 4-1. A summary of corroborative data and parameters are presented in Table 6-2.

Table 6-2. Corroborative Sources.

\begin{tabular}{|c|c|c|c|}
\hline Source & $\begin{array}{l}\text { Specifically Used } \\
\text { From: }\end{array}$ & Section Used In & Description \\
\hline Best 1982 & Page 197 & Section 6.5.3 & General composition of hawaiite basalt \\
\hline BSC 2003 [166407] & $\begin{array}{l}\text { Sections } 6.3 .2 .1 \\
\text { and 6.3.2.4, } \\
\text { Tables 6,7, and } 8 \\
\end{array}$ & $\begin{array}{l}\text { Sections } 1,5.4,6.4 .1 \text {, } \\
6.1,6.5 .1 .1,6.5 .2 \text {, } \\
6.5 .3 \text {, and } 6.6 .2 .1\end{array}$ & Assumptions and initial magma condition \\
\hline BSC 2003 [162153] & Section 6.2.4 & Sections 6.7 .2 and 8.1 & Rind volume \\
\hline BSC 2004 [167619] & Attachment VI & $\begin{array}{l}\text { Sections 6.5.1.2, } \\
\text { 6.6.2.1 and 6.7.2 }\end{array}$ & $\begin{array}{l}\text { Rind volume and borosilicate glass formulation } \\
\text { and basalt natural analogue }\end{array}$ \\
\hline BSC 2003 [163152] & Entire & $\begin{array}{l}\text { Sections 6.5.1.3, } \\
\text { 6.6.2.1, 6.7.1, and } \\
6.7 .2\end{array}$ & $\begin{array}{l}\text { Use of igneous MR results with the dissolved } \\
\text { concentrations MR }\end{array}$ \\
\hline BSC 2003 (165923) & Section 6.5 .1 & Section 5.4 and 6.5.2.2 & $\begin{array}{l}\text { Volatile gas flow between Zone } 1 \text { and Zone } 2 \\
\text { emplacement drifts after dike intrusion }\end{array}$ \\
\hline BSC 2003 (166845) & Entire & $\begin{array}{l}\text { Section } 1,6.1 \text {, and } \\
6.7 .2\end{array}$ & Use of igneous MR results with the colloids MR \\
\hline $\begin{array}{l}\text { CRWMS M\&O } \\
1999[121300]\end{array}$ & Section 6.0 & Section 6.5.1.1 & Behavior of materials in magma \\
\hline BSC 2004 [165057] & $\begin{array}{l}\text { Results Section } \\
6.0\end{array}$ & Section 6.5.1.1 & Behavior of materials in magma \\
\hline $\begin{array}{l}\text { CRWMS M\&O } \\
2001[153938]\end{array}$ & Attachment I & Section 6.4.4 & $\begin{array}{l}\text { Particle size distribution of crushed } \cup_{2} \text { and } \\
\text { how they were derived }\end{array}$ \\
\hline DOE 1982 & $\begin{array}{l}\text { Volume } 1 \text {, Section } \\
5.2 .3 \text { and Volume } \\
\text { II, Section } 6.2\end{array}$ & $\begin{array}{l}\text { Section } 6.6 .2 .1 \text { and } \\
6.7 .2\end{array}$ & $\begin{array}{l}\mathrm{pH} \text { and ionic strength of water in contact with } \\
\text { basalt }\end{array}$ \\
\hline Douglass 1983 & Results Section & $\begin{array}{l}\text { Sections } 6.4 .2 \text { and } \\
\text { 6.5.1.1 }\end{array}$ & $\begin{array}{l}\text { Products of reaction of magma and associated } \\
\text { gases with metals }\end{array}$ \\
\hline $\begin{array}{l}\text { Ehrlich and } \\
\text { Douglass } 1982\end{array}$ & Entire & $\begin{array}{l}\text { Sections } 6.4 .2 \text { and } \\
6.5 .1 .1\end{array}$ & Durability of metals in magma \\
\hline Einziger et al. 1991 & Entire & Section 6.4 .1 & Oxidation of $\mathrm{UO}_{2}$ \\
\hline Gordon 2003 & Sections 2 and 5 & $\begin{array}{l}\text { Sections 6.5.1.1 and } \\
7.1\end{array}$ & $\begin{array}{l}\text { Performance of waste packages and drip } \\
\text { shields in magmatic environments }\end{array}$ \\
\hline Hearn et al. 1985 & Table 2 & Section 5.4 and 6.7 .2 & $\begin{array}{l}\text { Size of basalt blocks within fractures and pH } \\
\text { for water in contact with basalt }\end{array}$ \\
\hline
\end{tabular}


Igneous Intrusion Impacts on Waste Packages and Waste Forms

Table 6-2 (Continued). Corroborative Sources.

\begin{tabular}{|c|c|c|c|}
\hline Source & $\begin{array}{l}\text { Specifically Used } \\
\text { From: }\end{array}$ & Section Used In & Description \\
\hline Hillner et al. 1998 & Entire & Section 6.5.1.1 & $\begin{array}{l}\text { Effects of high temperature water vapor on } \\
\text { cladding }\end{array}$ \\
\hline $\begin{array}{l}\text { Hofmann and } \\
\text { Kerwin-Peck } 1984\end{array}$ & Entire & Section 6.4 .1 & Reaction of zircaloy with $\mathrm{UO}_{2}$ \\
\hline $\begin{array}{l}\text { Hollingsworth and } \\
\text { Hunsicker } 1987\end{array}$ & Entire & Section 6.4.2 & Rates of aluminum corrosion \\
\hline $\begin{array}{l}\text { Klein and Hurlbut } \\
1999\end{array}$ & Pages 230-231 & Section 6.5.3.1 & Formational environments of dolomite \\
\hline $\begin{array}{l}\text { Li, Peacor, et al. } \\
1997\end{array}$ & Entire & Section 6.5.3.1 & Formational environments of celadonite \\
\hline $\begin{array}{l}\text { Li, Lowenstein, and } \\
\text { Blackburn } 1997\end{array}$ & Entire & Section 6.5.3.1 & Formational environments of celadonite \\
\hline Lichtner et al. 1999 & $\begin{array}{l}\text { Abstract, Pages 8- } \\
10 \text { of Section } \\
3.1 \text {, and page } 17 \\
\text { of Section } 3.3\end{array}$ & Sections 6.4 .3 & $\begin{array}{l}\text { Expected devitrification and revitrification of tuff } \\
\text { glass during an igneous intrusion }\end{array}$ \\
\hline Lide 2002 & Page 4-92 & $\begin{array}{l}\text { Section } 6.4 .1 \text { and } \\
6.5 .1 .2\end{array}$ & Melting point of $\mathrm{UO}_{2}$ \\
\hline McCright 1998 & $\begin{array}{l}\text { Supplement } 1 \text { and } \\
2\end{array}$ & Section 6.4 .2 & Corrosion rates of carbon steel \\
\hline $\begin{array}{l}\text { Parry and Straub } \\
1996\end{array}$ & Entire & $\begin{array}{l}\text { Section } 6.5 .3 \text { and } \\
6.6 .2 .1\end{array}$ & Composition of Lathrop Wells Cone basalts \\
\hline Roberts et al. 1990 & $\begin{array}{l}\text { Pages } 32,36, \\
149,394,515, \\
586,670-671 \text {, } \\
709-710,754 \text {, and } \\
881-882\end{array}$ & Sections 6.5.3 & Formational environments of minerals \\
\hline $\begin{array}{l}\text { Todreas and Kazimi } \\
1990\end{array}$ & Page 307 & $\begin{array}{l}\text { Section } 6.4 .1 \text { and } \\
6.5 .1 .2\end{array}$ & Melting point of commercial fuel \\
\hline Vaniman et al. 1982 & Pages 341-357 & $\begin{array}{l}\text { Sections } 6.5 .3 \text { and } \\
\text { 6.6.3.1 }\end{array}$ & $\begin{array}{l}\text { Crater Flat modal mineral basalt composition } \\
\text { and age of volcanic centers in Crater Flat }\end{array}$ \\
\hline $\begin{array}{l}\text { Wolery and Daveler } \\
1992\end{array}$ & Section 3.3.3 & 6.5 .3 .1 & TST formalism in EQ6 \\
\hline
\end{tabular}

Each stage of the sequence of events and processes, and their resulting effects on waste packages, drip shields, cladding, waste forms, and the in-drift environment of Zones 1 and 2 are described below.

\subsubsection{Intrusion of Basalt Magma into Zone 1 Emplacement Drifts}

There are two possibilities for the state of the magma as it moves upward into the repository (BSC 2003 [DIRS 165923):

- Magma steadily releases gas as it approaches the cavity and flows effusively into the repository cavity.

- Magma explosively releases gas from a magma/gas mixture as it approaches the cavity. 
The effects of flowing magma are outlined in the remainder of Section 6.5.1, consistent with decoupling of the igneous intrusion groundwater transport model from the eruptive model in TSPA.

\subsubsection{Impacts on Waste Packages}

In TSPA, the igneous intrusion event damages the waste packages and other barrier materials in Zone 1. The damage causes these barriers to fail, providing no further protection to the waste forms. The summary below provides further corroboration for this.

Several lines of evidence support that the igneous intrusion would render the drip shields, waste packages and cladding in the Zone 1 emplacement drifts ineffective so they would provide no further protection to the waste. These evaluations are summarized below.

The temperature of the intruding magma may be as high as $1169^{\circ} \mathrm{C}$ (BSC 2003 [DIRS:166407], Table 8). The melting temperatures of Alloy C-22 $\left(1357^{\circ} \mathrm{C}\right)$ and $316 \mathrm{NG}$ Stainless Steel $\left(1375^{\circ} \mathrm{C}\right)$ (CRWMS M\&O 1999, Section 5.1) are above the magma temperature, but the metals would certainly lose strength at the magma temperature.

Waste Package Behavior in Magma (CRWMS M\&O 1999) provides calculations of the pressures that would develop within waste packages as the result of gas expansion at high temperatures. It concludes that as temperatures approach $1200^{\circ} \mathrm{C}$ the resulting stresses on the packages would reach the tensile strength of the package materials. If a package has been corroded or otherwise weakened it would have a lower tensile strength that could be exceeded by the internal pressure developed at lower temperatures. This provides a possible mechanism for package breaching.

Findings of a literature review on the performance of waste package and drip shield materials in magmatic environments, documented by Structural Integrity Associates (Gordon 2003, Section 5), suggest that the structural integrity of these materials would be severely compromised and damage could occur. For example, Types 310 and 446 stainless steels, exposed to Hawaiian basaltic lava at $1300^{\circ} \mathrm{C}$ and 2 psi for 100 hours, underwent extensive reaction and damage, while alloy 718 suffered a loss of structural integrity (Gordon 2003, Section 5).

During the course of magma cooling, waste packages and canisters/assemblies may be subject to corrosion, the degree of which may vary depending on their composition, contact magma temperature, and in situ geochemical environment. Magma temperatures, pressures, and geochemical environment in the drift, influenced by the magma composition and volume of exsolving volatile gases, such as $\mathrm{H}_{2} \mathrm{O}, \mathrm{H}_{2}, \mathrm{CO}_{2}, \mathrm{CO}, \mathrm{SO}_{2}, \mathrm{~S}_{2}, \mathrm{HCl}, \mathrm{HF}$, and $\mathrm{H}_{2} \mathrm{~S}$ may have a significant impact on corrosion rates. Literature review findings related to oxidation, sulfidation and corrosion behavior and rates of Alloy 22 waste package materials, drip shield titanium alloy, and similar alloys in magmatic environments shed light on the degree of corrosion (Gordon 2003, Section 2).

Kinetic corrosion rate calculations suggest that Zircaloy cladding can be significantly damaged by corrosion in a matter of days in the presence of water vapor at temperatures between $250^{\circ} \mathrm{C}$ to $360^{\circ} \mathrm{C}$ (Hillner et al. 1998; CRWMS M\&O 2000). Based on this information, damage to cladding could occur after the intrusion of magma with exsolving volatiles. 
One study of binary and ternary alloys containing various amounts of molybdenum and chromium and exposed to basaltic magma at $1150^{\circ} \mathrm{C}$ for periods of 24 and 96 hours shows that the formation of secondary phases and oxidation or sulfidation of metals is extremely dependent on metal composition (Ehrlich and Douglass 1982; Douglass 1983). Another finding, from a qualitative study of various alloys in contact with Hawaiian basalt lava, indicates that Types 310 and 446 stainless steel reacted extensively with the degassed lava while Udimet 700 and Alloy 718 suffered a loss of structural integrity (Gordon 2003, Section 5). Findings from another study, conducted at $727^{\circ} \mathrm{C}$ for 96 hours, indicate that under a reducing atmosphere of 1.5 percent $\mathrm{H}_{2} \mathrm{~S}$ and 98.5 percent $\mathrm{H}_{2}$, the corrosion is significantly higher than in an oxidizing-sulfidizing environment with 59 percent $\mathrm{Ar}, 3$ percent $\mathrm{O}_{2}, 36.5$ percent $\mathrm{H}_{2}$, and 1.5 percent $\mathrm{H}_{2} \mathrm{~S}$ (Gordon 2003, Section 2). All these corroborative findings suggest that metals embedded in the cooling basalt magma would be subjected to various degrees of corrosion.

\subsubsection{Impact on Waste Forms}

With the failure of the waste packages, the waste forms are also subject to disruption. Effects may include:

- Exposure to high temperatures

- Chemical interactions with magma and associated fluids and gases which could alter the solubility of the waste forms.

The types and extents of such changes would depend upon such factors as the degree and duration of magma contact with waste forms, the contact pressure, viscosity, temperature; the redox conditions at the time of intrusion, and the physical and chemical characteristics of the waste forms. The spent fuel within the commercial fuel rods is a ceramic material with a high melting point temperature with a range of approximately $2600^{\circ} \mathrm{C}$ (Todreas and Kazimi 1990 , Page 307 for LWR fuels) to $2800^{\circ} \mathrm{C}$ (Lide 2002, Page 4-92 for $\mathrm{UO}_{2}$ ). Therefore, the commercial spent nuclear fuel exposed to hot magma is not expected to melt at temperatures up to the maximum magma temperature of $1169^{\circ} \mathrm{C}$ (BSC 2003 [DIRS:166407], Table 8).

As indicated in Section 6.4.1, chemical interaction between waste forms and the magma and chemical interaction between the waste forms and the metal of waste canisters/assemblies and cladding in the presence of hot magma can occur. Since the extent of development of mineral phases is unknown and would tend to limit subsequent reactivity of the altered waste forms, the waste is considered conservatively chemically unchanged.

The heating of canistered glass waste forms to temperatures near $1150^{\circ} \mathrm{C}$ by magma during an intrusion event followed by slow cooling will result in the glass melting and possibly devitrification as the glass cools. The extent of devitrification will depend on the composition of the glass, temperature, and cooling rate. Borosilicate HLW glasses are currently formulated to minimize the formation of precipitates while molten in the melter (at about $1150^{\circ} \mathrm{C}$ ) and as they solidify in the steel canister. The waste loading of most HLW streams processed with a Jouleheated melter are limited by formation of phases in the glass-melt such as spinel $(\mathrm{Ni}, \mathrm{Fe}, \mathrm{Mn})(\mathrm{Cr}, \mathrm{Fe})_{2} \mathrm{O}_{4}$ and acmite $\mathrm{NaFe}\left(\mathrm{Si}_{2} \mathrm{O}_{6}\right)$, particularly for Fe-rich waste streams. The formation of these phases does not have a significant impact on the glass durability because the 
silicate network is not significantly affected by the formation of these phases (BSC 2004 [DIRS:167619]).

The formation of some phases reduces the chemical durability of the glass. Glasses are formulated to avoid formation of phases such as nepheline $\left(\mathrm{NaAlSiO}_{4}\right)$ because they lead to a composition change in the glass. Composition changes that result in a higher proportion of alkali in the glass usually reduce the glass durability. This can occur when a higher proportion of components that form the silicate structure of the glass, such as $\mathrm{Al}$ and $\mathrm{Si}$, are removed from the glass melt than components that interrupt the glass structure, such as alkali metals, as these phases form. Likewise, glass additives are controlled to avoid both the formation of soluble inclusion phases, such as lithium metasilicate $\left(\mathrm{Li}_{2} \mathrm{SiO}_{3}\right)$, and glass/glass phase separation. The lower cooling rate of glass that remelts in the repository will remain within the range that is favorable for precipitating spinels, nepheline, etc (at $600-900^{\circ} \mathrm{C}$ ) for longer periods than during glass manufacture. The formation of less durable phases could impact the performance of waste (BSC 2004 [DIRS:167619]). However, the slow cooling also results in less cracking and less exposed glass surface area than occurs in manufacture. Because the extent of secondary phases in the glass in unknown and the decrease in exposed surface area will aid in durability, the glass is considered to be unchanged.

\subsubsection{Results of Base Case Model for Waste Form Properties in Basalt-Filled (Zone 1) Drifts}

It is conservatively concluded that the igneous intrusion would render the drip shields, waste packages, and cladding in the Zone 1 emplacement drifts ineffective so they would provide no further protection to spent fuel and waste forms.

It is also concluded that the waste packages would be distributed throughout the cooled magma, though exactly how is unknown. Spent fuel is a refractory material and in the base case is considered to be chemically unaffected by exposure to the intruding magma. Likewise, waste glass is considered to be minimally affected because HLW glasses are currently formulated to minimize the formation of mineral precipitates which could effect the durability of the material.

Because waste forms are considered chemically unchanged (see Section 6.5.1.2) in the base case model, the dissolved concentration of radioelements in seepage water in the basalt that has reacted with waste forms would have the same dependency on water chemistry as does waste dissolving in the nominal case. Thus, the solubility tables given in Dissolved Concentration Limits of Radioactive Elements (BSC 2003 [DIRS:163152]) should be used to determine concentrations of radionuclides in water in basalt-filled drifts the same way that they are used in the nominal case.

\subsubsection{Heat and Gas Flow from Zone 1 Emplacement Drifts Filled with Basalt Magma}

\subsubsection{Numerical Simulations of Non-Steady State Heat Conduction with Radial Flow}

The temperature distribution for a magma flow filling a Zone 1 emplacement drift can be estimated using a highly idealized, one-dimensional unsteady heat conduction in a rod model, subject to constant heat content. This is a simplified model used to determine the length of time it 
takes for the repository to cool back to $100^{\circ} \mathrm{C}$, and thus at which time water re-enters the system. The contribution of latent heat and heat transfer due to convection is neglected. The magma is considered to be at an initial intrusive temperature of $1150^{\circ} \mathrm{C}$ (BSC 2003 [DIRS:166407]). The magma fills the drift entirely and the temperature dissipates both spatially and temporally. The temperature of the repository is considered to be between $25^{\circ} \mathrm{C}$ to $200^{\circ} \mathrm{C}$ at the time of the intrusion. The heat transfer thermal properties of the magma are considered to be the same as those for the densely welded tuff (see Section 5.3) for a first order analysis. The logic flow for the heat conduction model is presented in detail, along with pertinent equations, in Attachment $I$.

\subsection{Results of Model Simulations}

The model simulations and analysis consider four types of lithophysal and nonlithophysal units that comprise the repository horizon (Tptpul, Tptpmn, Tptpll, and Tptpln). All of these units are from the Topopah Spring Tuff (Tpt). The fourth letter in the unit designation represents the crystal poor zone of this tuff. The last two letters in each unit designator are defined as follows: $\mathrm{ul}=$ upper lithophysal zone, $\mathrm{mn}=$ middle nonlithophysal zone, $\mathrm{ll}=$ lower lithophysal zone, and $\ln =$ lower nonlithophysal zone. To cover a broad range of potential conditions, the analysis assumes two different alternative thermal properties of the tuff matrix: saturated with water, and void of water (dry conditions). The model considers ideal saturation: completely saturated and completely dry (as opposed to real saturation conditions, which are somewhere in between). Simulations of radial conduction of intrusive heat into the areas surrounding the intruded emplacement drifts are carried out.

The magma intrudes into the Zone 1 emplacement drifts in a single instantaneous event at a temperature of $1150^{\circ} \mathrm{C}$, and heat diffuses to the surrounding welded tuff units by radial heat conduction with constant heat content. The rate at which thermal diffusion takes place depends on the thermal conductivity, and the volumetric heat capacity of the welded tuff.

The results of the analysis for different repository horizon rock units for a period of 50 years are presented in Figures 6-1 and 6-2 for the wet and dry analysis for Tptpll. The results for the three other regions were so similar to the Tptpll results, that the differences can not be distinguished in the graphs, and only the results for Tptpll were plotted. These figures show a simplified configuration of intruded drift and the adjacent drift. The results show that the temperatures near the drift are high. However, the temperatures attenuate rapidly into the surrounding tuff. The peak temperature is reduced with radius and shifted out in time. For example, the peak temperature at a 10-meter radius is less than boiling, and is attained after one year while the peak temperature at a radius of $20 \mathrm{~m}$ is approximately $40^{\circ} \mathrm{C}$ after several years. Under either completely dry or completely wet conditions, the temperature reduces to about $30^{\circ} \mathrm{C}$ at drift center in about 30 years. Further, the analysis shows that the high temperatures after the magma event attenuate rapidly with distance. The maximum temperature rise in the adjacent emplacement drifts in Zone 2 is small (less than $10^{\circ} \mathrm{C}$ ), and the rock provides an effective thermal barrier to the impacts of heat transfer from magmatic intrusion. Therefore, the spatial and temporal heat conduction simulations and analysis suggest that the waste packages in Zone 2 emplacement drifts would not be affected by the heat conducting from the magma intruded into Zone 1 emplacement drifts. 


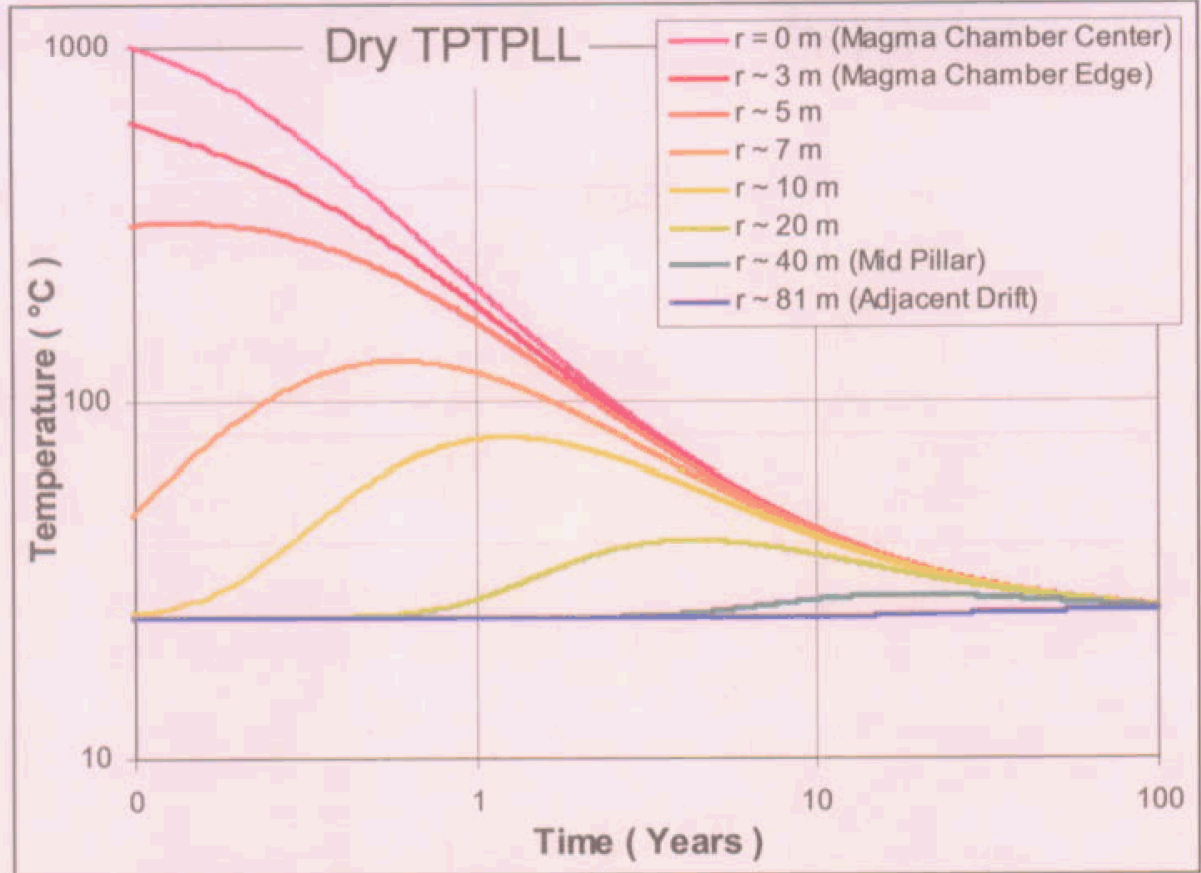

Figure 6-1. Heat Conduction from Magma Flow for Dry Tptpll

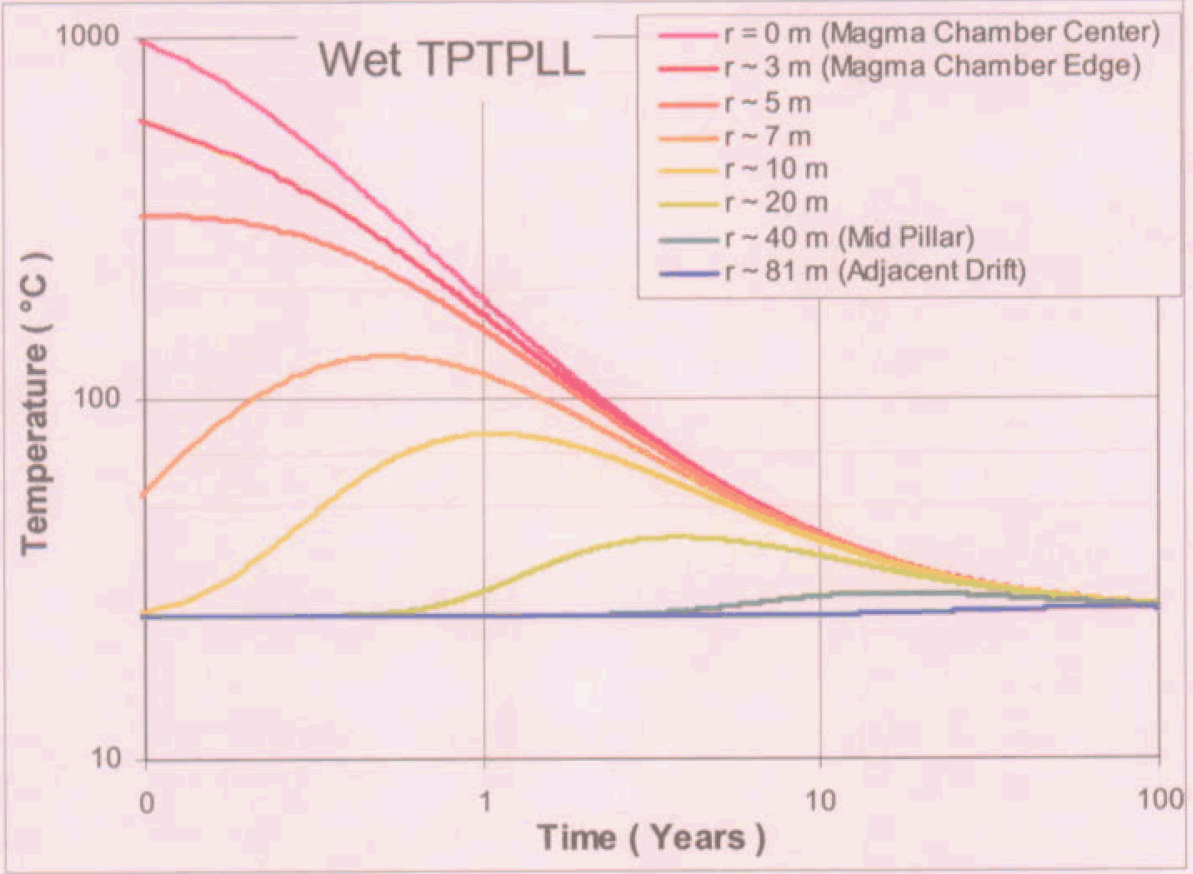

Figure 6-2. Heat Conduction from Magma Flow for Wet Tptpll 


\subsection{Heat Flow Sensitivity}

\section{Latent Heat}

The latent heat generated by the crystallization of the cooling magma can be significant, as shown in Dike/Drift Interactions (BSC 2003 [DIRS: 165923]). Latent heat will likely add a significant amount of heat at early times, increasing the temperature by as much as $100^{\circ} \mathrm{C}$, and will prolong the cooling times within the magma, as shown in Dike/Drift Interactions (BSC 2003 [DIRS: 165923], Section 6.5.2.6). However, this effect was examined in a sensitivity study by rerunning the model at $1250^{\circ} \mathrm{C}$, to roughly account for the latent heat. The results are compared with the base case and presented in Figures 6-3 and 6-4. The figures show little change in the results. At the center of the drift, the temperature falls below $100^{\circ} \mathrm{C}$ at 2.51 years, or at 2.73 years if the effects of latent heat are approximated. At the drift wall, the temperature falls below $100^{\circ} \mathrm{C}$ at 2.46 years, or at 2.59 years if the effects of latent heat are approximated. Considering the geologic timeframes of interest, this difference is negligible.

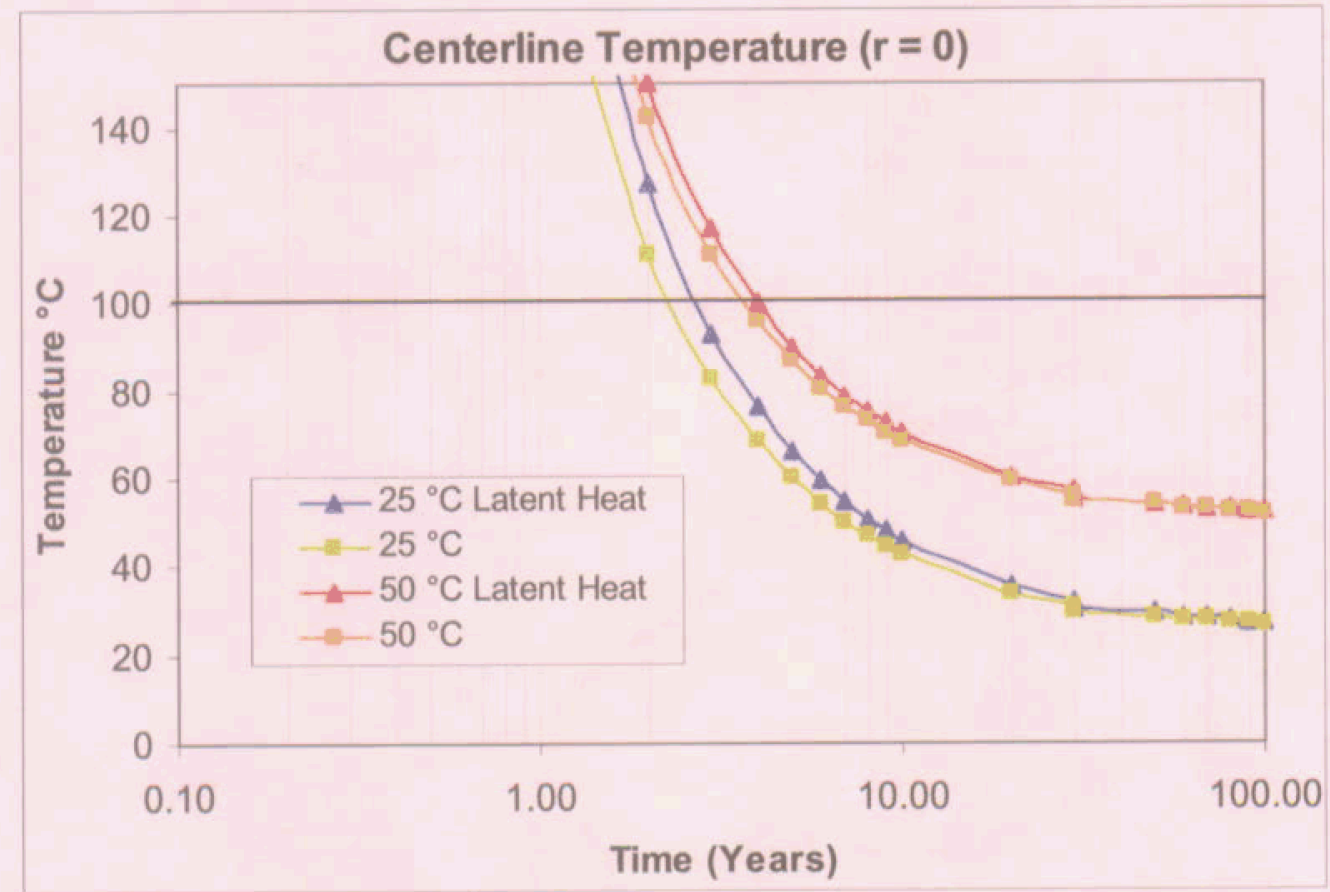

Figure 6-3: Latent Heat Effect at Centerline 


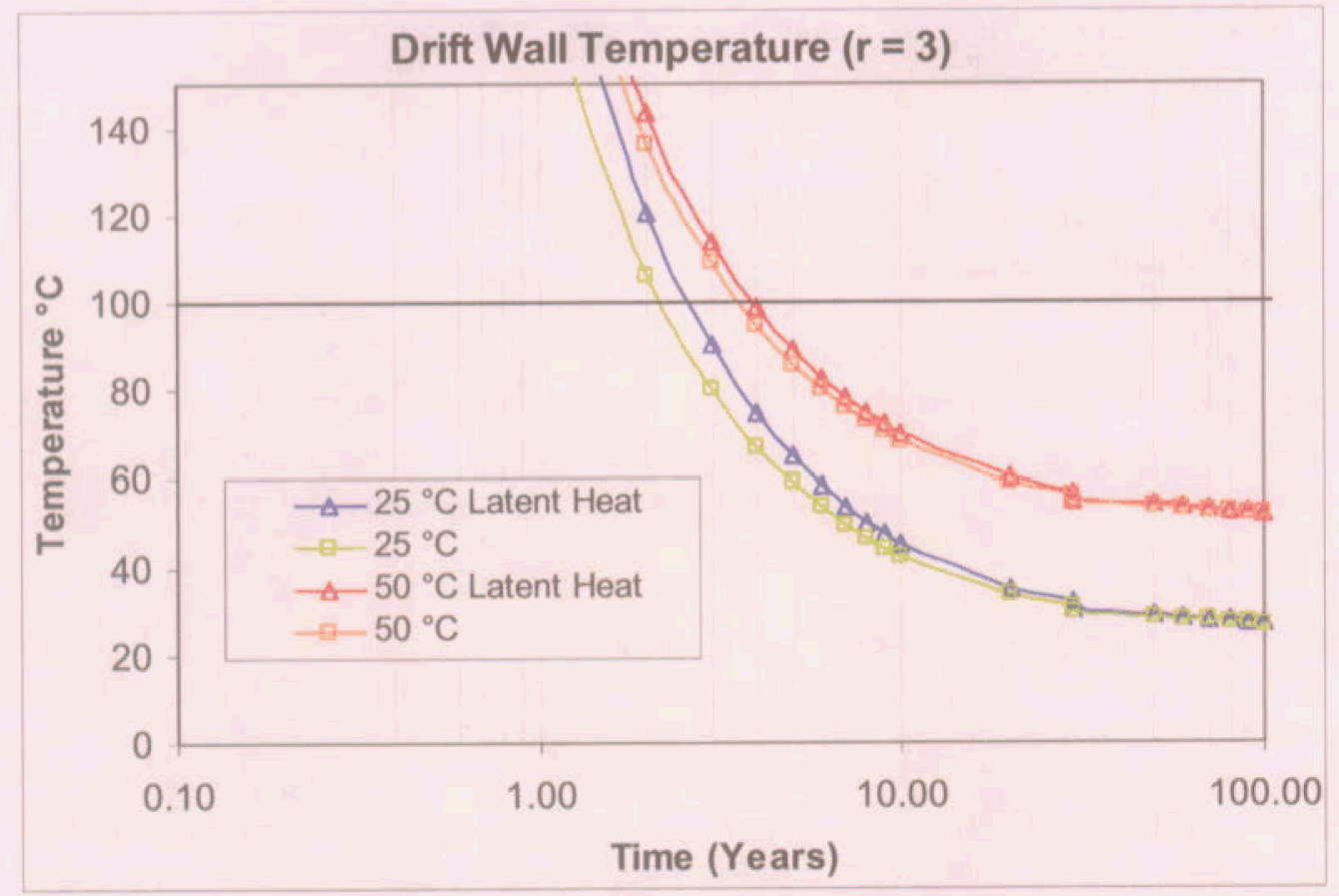

Figure 6-4: Latent Heat effect at Drift Wall

\section{Saturation}

BSC 2004 ([DIRS 168720], Section 8.1) shows that the change in temperature based on the saturation of the matrix is less than $5 \%$, therefore the effects of enhanced vapor diffusion will be minimal. Convection in the saturated matrix is also a consideration, but is expected to be minimal based on the low porosity of the rock, the fact that the temperatures attenuate rapidly over time, and that the high temperatures are only sustained over short distances.

\subsubsection{Flow of Volatile Gas Components from Intrusive Magma}

The flow of air, $\mathrm{H}_{2} \mathrm{O}, \mathrm{SO}_{2}$, and $\mathrm{CO}_{2}$ between Zone 1 and Zone 2 emplacement drifts is analyzed in Dike/Drift Interactions (BSC 2003 [DIRS: 165923]). The model report concludes that the boiling zone created within the intruded drift limits the migration of those gases. As well as the dissolution of gases into the aqueous phase, the gases would diffuse back into the rock matrix after pressures from the intrusion subside. Gases flowing through the coarse backfill in perimeter drifts would be diluted by air. Crushed tuff material and water content would also retard gas movement. In addition, oxidation/reduction reactions involving sulfur species would further retard gas migration.

Characterize Eruptive Processes at Yucca Mountain, Nevada (BSC 2003 [DIRS:166407]) recommends a composition of volatile gases in mole percent. BSC 2003 [DIRS: 165923] shows that the gases that compose the majority ( 96.89 mole percent from BSC 2003 [DIRS:166407]) of the exsolved gases $\left(\mathrm{H}_{2} \mathrm{O}, \mathrm{CO}_{2}\right.$, and $\left.\mathrm{SO}_{2}\right)$ are significantly retarded so that they have no effect on Zone 2 emplacement drifts. It is therefore assume (Section 5.4) that other reactive gases such as $\mathrm{HF}$ and $\mathrm{HCl}$, which are present in minor quantities in the gas front $(0.87$ and 0.17 mole percent respectively, BSC 2003 [DIRS:166407]), are also retarded. 
Therefore, it is concluded that the waste packages in Zone 2 emplacement drifts would not be impacted by volatile gases exsolving from the basalt magma intruded into Zone 1 emplacement drifts.

\subsubsection{Reaction of Seepage Water with Basalt After Reversion to Normal In-Drift Environmental Conditions}

After post-intrusive magma cooling and reversion to normal in-drift environmental conditions, the seepage water is expected to flow through the contact metamorphic aureole and react first with the basalt in the intruded emplacement drifts, resulting in basalt-equilibrated seepage water. The geochemical interaction of seepage water with the basalt and the resulting hydrochemistry are simulated using EQ3/6.

The following sections describes calculated parameters used as inputs into EQ6 simulations. All data for EQ6 simulations taken directly from controlled sources can be found in Section 4.1.2. The results of the EQ6 simulations are located in Section 6.5.3.4.

The abstracted minerals used in the simulations were derived by manipulation of the oxide chemical composition of the basalt taken from Characterize Eruptive Processes at Yucca Mountain, Nevada (BSC 2003 [DIRS:166407]) to reflect, as much as possible, the mineral composition of Crater Flat basalt described by Vaniman et al. (1982) and Perry and Straub (1996). The "normative calculation" which converts the basalt composition in oxides to composition in minerals (presented in Table 6-3) was based on the following points:

- Vaniman et al. (1982) indicates that the groundmass is primarily plagioclase, pyroxene, and olivine with olivine phenocrysts (up to 3\%). Perry and Straub (1996) indicate a groundmass composition of plagioclase, olivine, titanomagnetite, and clinopyroxene with olivine and plagioclase phenocrysts. Plagioclase phenocrysts are found primarily in chronostratigraphic unit I and largely absent from chronostratigraphic units II, III, and IV (See Perry and Straub 1996 for definition of units).

- Olivine phenocrysts comprise three modal percent of the youngest basalt at Crater Flat Vaniman et al. (1982). The phenocrysts are entirely olivine The olivine in the normative calculation was divided between the two end members of forsterite (Mg-olivine) and fayalite (Fe-olivine) with forsterite composing between $76-79 \%$ of the olivine (Vaniman et al., 1982).

- The plagioclase feldspar andesine is indicated as the major plagioclase species in the Crater Flat area (Vaniman et al., 1982). However, this mineral is not included in the EQ6 database and must therefore be represented in the normative analysis by the two end members albite and anorthite. According to Vaniman et al. (1982), the end member anorthite represents $30-53 \%$ of the plagioclase.

- Pyroxenes in the Crater Flat area are primarily augite and hypersthene. Hypersthene, which is isomorphous with enstatite, is not included in the EQ6 database and must therefore be represented in the normative analysis by enstatite. Augite is also not included in the EQ6 database. Although augite can be described by the end members of 
diopside and hedenbergite, for simplicity in the normative analysis, only hedenbergite was used.

- Nepheline is not indicated as a major mineral at Crater Flat in Vaniman et al. (1982). However, it is included in their normative analysis of the Lathrop Wells Cone at between 0 and 2.2 percent, indicating that the Lathrop Wells Cone basalt is sufficiently silica poor that nepheline, under certain conditions, may form. Additionally, hawaiite basalts are known to contain minor nepheline (Best 1982) so a small portion is justified here.

- Sanidine is not indicated as a major mineral at Crater Flat in Vaniman et al. (1982). However, orthoclase is included in their normative analysis of the Lathrop Wells Cone at 10.5 percent. Sanidine is a monoclinic disordered orthoclase felspar very common as a constituent of acidic and alkaline volcanic rocks (Roberts et al, 1990, p. 754) and was thusly considered justified here. Therefore, sanidine was included to account for the $\mathrm{K}_{2} \mathrm{O}$ in the normative analysis.

- The apatite group consists of minerals commonly found in igneous rocks. Although apatite is not indicated as a major mineral at Crater Flat in Vaniman et al. (1982), it is included in their normative analysis of the Lathrop Wells Cone at 2.4 to 3.0 percent. The mineral hydroxylapatite (Roberts et al., 1990, p. 389) was added to account for the $\mathrm{P}_{2} \mathrm{O}_{5}$ in the normative analysis.

- Several of the minerals above can contain minor amounts of titanium. However, due to database constraints, this cannot be taken into account. Also, Vaniman et al. (1982) mention the amphibole magnesiokaersutite which can contain up to $4 \% \mathrm{TiO}_{2}$. This amphibole is rare at Crater Flat and thermodynamic data for it are not included in the EQ6 database, so it was not taken into account. Therefore, ilmenite was used for all the $\mathrm{TiO}_{2}$ in the normative analysis. Ilmenite is widespread as a common accessory mineral in igneous rocks. (Roberts et al., 1990, p. 394). The use of ilmenite is also supported by the normative analysis of the Lathrop Wells Cone done in Vaniman et al. (1982) that shows 2.5 to 2.6 percent ilmenite.

- Magnetite was allotted the remaining iron in the normative analysis. Magnetite occurs abundantly and widespread as magmatic segregations and as an accessory mineral in igneous rocks. (Roberts et al., 1990, p. 515). In the normative analysis presented in Vaniman et al. (1982), magnetite and hematite have a combined percentage between 3.6 and 3.9 . 
Table 6-3. Idealized Mineral Composition of Basalt

\begin{tabular}{|l|l|l|l|}
\hline \multicolumn{1}{|c|}{ EQ6 Minerals } & \multicolumn{1}{|c|}{$\begin{array}{c}\text { EQ6 Mineral } \\
\text { Formula }\end{array}$} & $\begin{array}{c}\text { Mineral } \\
\text { Molecular } \\
\text { Weight }\end{array}$ & \multicolumn{1}{c|}{ Wt\% $^{\text {a }}$} \\
\hline Forsterite & $\mathrm{Mg}_{2} \mathrm{SiO}_{4}$ & 140.69 & 2.363 \\
\hline Fayalite & $\mathrm{Fe}_{2} \mathrm{SiO}_{4}$ & 203.77 & 0.90977 \\
\hline Magnetite & $\mathrm{Fe}_{3} \mathrm{O}_{4}$ & 231.53 & 6.06248 \\
\hline IImenite & $\mathrm{FeTiO}_{3}$ & 151.71 & 3.69225 \\
\hline Hydroxylapatite & $\mathrm{Ca}_{5}\left(\mathrm{PO}_{4}\right)_{3}(\mathrm{OH})$ & 502.31 & 2.8987 \\
\hline Sanidine & $\mathrm{KAISi}_{3} \mathrm{O}_{8}$ & 278.33 & 10.9511 \\
\hline Anorthite & $\mathrm{CaAl}_{2}\left(\mathrm{SiO}_{4}\right)_{2}$ & 278.21 & 24.5643 \\
\hline Albite & $\mathrm{NaAlSi}_{3} \mathrm{O}_{8}$ & 262.22 & 25.6512 \\
\hline Nepheline & $\mathrm{NaAlSiO}_{4}$ & 142.05 & 2.40048 \\
\hline Hedenbergite & $\mathrm{FeCaSi}_{2} \mathrm{O}_{6}$ & 248.09 & 9.25437 \\
\hline Enstatite & $\mathrm{MgSiO}_{3}$ & 100.39 & 11.2524 \\
\hline \\
Source: a Values above calculated in "basalt-separated.xls" in \\
Attachment III (Disc 1) from composition provided in Table 4-3.
\end{tabular}

\subsubsection{EQ6 Basalt/Water Interaction}

EQ6 also requires the input of mineral surface areas and moles. These values, calculated in "basalt-separated.xls" in Attachment III (Disc 1) are shown in Table 6-4. It should be noted that these values are based on having meter sized basalt blocks (see Section 5.2) in the fractured areas and a saturation of 0.1 (saturation of 0.12 from Table 4-9 rounded to 0.1 ).

Table 6-4. Surface Area and Moles of Mineral Reactants

\begin{tabular}{|l|c|c|}
\hline \multicolumn{1}{|c|}{ Mineral } & Moles & $\begin{array}{c}\text { Surface Area } \\
\left(\mathbf{c m}^{2}\right)\end{array}$ \\
\hline Forsterite & $2.531 \mathrm{E}+01$ & $6.92 \mathrm{E}+01$ \\
\hline Fayalite & $6.728 \mathrm{E}+00$ & $2.67 \mathrm{E}+01$ \\
\hline Magnetite & $3.946 \mathrm{E}+01$ & $1.78 \mathrm{E}+02$ \\
\hline Ilmenite & $3.668 \mathrm{E}+01$ & $1.08 \mathrm{E}+02$ \\
\hline Hydroxylapatite & $8.697 \mathrm{E}+00$ & $8.49 \mathrm{E}+01$ \\
\hline Sanidine & $5.930 \mathrm{E}+01$ & $3.21 \mathrm{E}+02$ \\
\hline Anorthite & $1.331 \mathrm{E}+02$ & $7.20 \mathrm{E}+02$ \\
\hline Albite & $1.474 \mathrm{E}+02$ & $7.51 \mathrm{E}+02$ \\
\hline Nepheline & $2.547 \mathrm{E}+01$ & $7.03 \mathrm{E}+01$ \\
\hline Hedenbergite & $5.622 \mathrm{E}+01$ & $2.71 \mathrm{E}+02$ \\
\hline Enstatite & $1.689 \mathrm{E}+02$ & $3.30 \mathrm{E}+02$ \\
\hline
\end{tabular}

NOTE: Calculated in "basalt-separated.xls" in Attachment III (Disc 1) From values in Table 6-3

The dissolution rates of materials come from various literature sources and are presented in Tables 4-5, 4-6, and 4-7. The calculated rates for EQ6 calculations using those rates from Tables 4-5, 4-6, and 4-7 are presented in Table 6-5 and Attachment II. The rates for the minerals in the EQ6 cases were cast in the transition state theory formalism (Wolery and Daveler 1992, 
Section 3.3.3). The sources for the mineral dissolution rates are used here because they come from peer reviewed journals and in many cases they are the only source of information available for dissolution of minerals. A more in-depth discussion on the mineral dissolution rates can be found in Attachment II.

Table 6-5. Dissolution Rates of Basaltic Minerals

\begin{tabular}{|l|c|c|c|c|}
\hline \multirow{2}{*}{ Mineral } & \multicolumn{2}{|c|}{ Acidic leg } & \multicolumn{2}{c|}{ Basic Leg } \\
\cline { 2 - 5 } & $\mathbf{k}_{1}$ & $\mathbf{S 1}$ & $\mathbf{k}_{\mathbf{2}}$ & S2 \\
\hline Anorthite & $1.58 \mathrm{E}-11$ & 0.91 & $2.0 \mathrm{E}-18$ & -0.3 \\
\hline Albite low & $7.94 \mathrm{E}-15$ & 0.33 & $5.01 \mathrm{E}-19$ & -0.32 \\
\hline Nepheline & $3.98 \mathrm{E}-08$ & 1.0 & $7.94 \mathrm{E}-15$ & -0.2 \\
\hline Sanidine high & \multicolumn{4}{|c|}{ Used same rate as albite } \\
\hline Fayalite & $7.94 \mathrm{E}-12$ & 0.4 & $5.25 \mathrm{E}-15$ & 0 \\
\hline Forsterite & $7.94 \mathrm{E}-12$ & 0.4 & $5.25 \mathrm{E}-15$ & 0 \\
\hline Enstatite & $1.58 \mathrm{E}-12$ & 0.57 & $1.26 \mathrm{E}-19$ & -0.44 \\
\hline Hedenbergite & $3.16 \mathrm{E}-11$ & 0.7 & $6.31 \mathrm{E}-16$ & 0 \\
\hline Hydroxylapatite & $1.00 \mathrm{E}-12$ & 0.35 & $1.17 \mathrm{E}-17$ & -0.35 \\
\hline IImenite & $4.57 \mathrm{E}-13$ & 0.462 & $1.55 \mathrm{E}-19$ & -0.462 \\
\hline Magnetite & $2.09 \mathrm{E}-13$ & 0.232 & $1.17 \mathrm{E}-16$ & -0.232 \\
\hline
\end{tabular}

NOTES: Total Dissolution Rate $=k_{1}\left[H^{+}\right]^{s 1}+k_{2}\left[H^{+}\right]^{s 2}\left(\right.$ moles $\left./ \mathrm{cm}^{2} \cdot s\right)$.

All values above were extrapolated in Microsoft Excel spreadsheets "Aluminosilicate rates.xls", "pyroxene rates.xIs", "olivine rate.xls", "oxides rate.xls", and "apatite rate.xls" in Attachment III (Disc 1) from rats in Tables 4-5, 4-6, and 4-7.

"S" represents the negative slope of the $\mathrm{Log}($ rate) versus $\mathrm{pH}$ presented in this table and in Attachment II

The composition of the water running through the basalt block (Table 6-6) is the EQ3 equilibrated Bin 8 seepage water from DTN: MO03010SPAEBSCB.003. The flow rates below were derived from infiltration rates in DTN: LB0310AMRU0120.001 and are calculated in "basalt-separated.xls" on Attachment III (Disc 1).

Table 6-6. Water Composition and Flow Rate Used in the EQ3/6 Input Files of Water/Basalt Interaction

\begin{tabular}{|l|l|l|l|c|l|l|}
\hline \multicolumn{3}{|c|}{ EQ3NR Input Composition Values } & \multicolumn{3}{c|}{ EQ6 Input File Composition } \\
\hline Element & $\begin{array}{c}\text { Basis } \\
\text { Switch }\end{array}$ & Concentration & \multicolumn{1}{c|}{ Units } & Element & Concentration & Units \\
\hline redox & & $-0.7^{\mathrm{b}}$ & $\mathrm{Log} \mathrm{fO} 2$ & $\mathrm{Na}$ & $7.31 \mathrm{E}-03$ & Moles $/ \mathrm{kg}$ \\
\hline $\mathrm{Na}^{+}$ & & 168.0 & $\mathrm{mg} / \mathrm{L}$ & $\mathrm{Si}$ & $1.80 \mathrm{E}-03$ & Moles $/ \mathrm{kg}$ \\
\hline $\mathrm{SiO}_{2}$ (aq) & & 108.0 & $\mathrm{mg} / \mathrm{L}$ & $\mathrm{Ca}$ & $5.74 \mathrm{E}-04$ & Moles $/ \mathrm{kg}$ \\
\hline $\mathrm{Ca}^{++}$ & & 23.0 & $\mathrm{mg} / \mathrm{L}$ & $\mathrm{K}$ & $2.76 \mathrm{E}-04$ & Moles $/ \mathrm{kg}$ \\
\hline $\mathrm{K}^{+}$ & & 10.8 & $\mathrm{mg} / \mathrm{L}$ & $\mathrm{Mg}$ & $8.52 \mathrm{E}-05$ & Moles $/ \mathrm{kg}$ \\
\hline $\mathrm{Mg}^{++}$ & & 2.07 & $\mathrm{mg} / \mathrm{L}$ & $\mathrm{O}$ & $5.55 \mathrm{E}+01$ & Moles $/ \mathrm{kg}$ \\
\hline $\mathrm{H}^{+}$ & & 7.94 & $\mathrm{pH}$ & $\mathrm{F}$ & $6.42 \mathrm{E}-04$ & Moles $/ \mathrm{kg}$ \\
\hline $\mathrm{F}^{-}$ & & 12.2 & $\mathrm{mg} / \mathrm{L}$ & $\mathrm{Cl}$ & $5.61 \mathrm{E}-04$ & Moles $/ \mathrm{kg}$ \\
\hline $\mathrm{Cl}^{-}$ & & 19.9 & $\mathrm{mg} / \mathrm{L}$ & $\mathrm{N}$ & $3.97 \mathrm{E}-05$ & Moles $/ \mathrm{kg}$ \\
\hline $\mathrm{NO}_{3}^{-}$ & $\mathrm{NH}_{3}(\mathrm{aq})$ & 2.46 & $\mathrm{mg} / \mathrm{L}$ & $\mathrm{S}$ & $3.55 \mathrm{E}-04$ & Moles $/ \mathrm{kg}$ \\
\hline $\mathrm{SO}_{4}^{-}$ & & 34.1 & $\mathrm{mg} / \mathrm{L}$ & $\mathrm{Al}$ & $1.50 \mathrm{E}-09$ & Moles $/ \mathrm{kg}$ \\
\hline
\end{tabular}


Table 6-6 (Continued). Water Composition and Flow Rate Used in the EQ3/6 Input Files of Water/Basalt Interaction

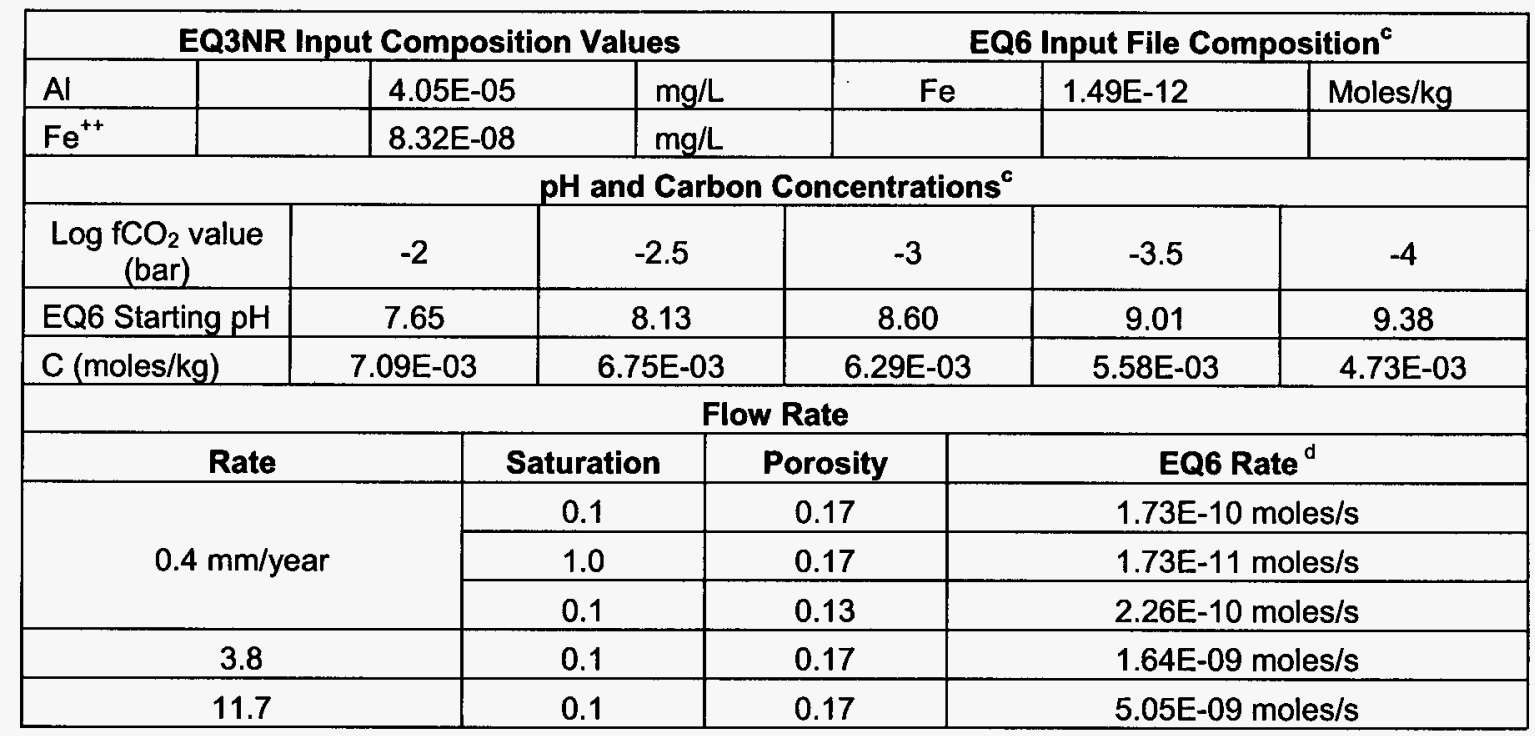

NOTES: ${ }^{a}$ Calculated in "conversions.xIs" in Attachment II from values in Table 4-8.

bEquilibrium atmospheric levels of oxygen.

'These values are the output from EQ3NR for input into EQ6 input files.

"Calculated in Microsoft Excel spreadsheet "basalt-separated.xls".

By changing the saturation to 1.0 from 0.1 and the pore fraction from 0.17 to 0.13 , the moles and surface areas of minerals input into EQ6 also change slightly from the base case. These values are presented in Table 6.7 .

Table 6-7. Surface Area and Moles of Mineral Reactants with Different Pore Fraction and Saturation

\begin{tabular}{|l|c|c|c|c|}
\hline \multicolumn{1}{|c|}{ Mineral } & \multicolumn{2}{|c|}{ Saturation of 1.0 } & \multicolumn{2}{c|}{ Pore fraction of 0.13 } \\
\hline Forsterite & $2.531 \mathrm{E}+00$ & $6.92 \mathrm{E}+00$ & $3.470 \mathrm{E}+01$ & $\begin{array}{c}\text { Surface Area } \\
\left(\mathrm{cm}^{2}\right)\end{array}$ \\
\hline Fayalite & $6.728 \mathrm{E}-01$ & $2.67 \mathrm{E}+00$ & $9.223 \mathrm{E}+00$ & $3.65 \mathrm{E}+01$ \\
\hline Magnetite & $3.946 \mathrm{E}+00$ & $1.78 \mathrm{E}+01$ & $5.409 \mathrm{E}+01$ & $2.43 \mathrm{E}+02$ \\
\hline Ilmenite & $3.668 \mathrm{E}+00$ & $1.08 \mathrm{E}+01$ & $5.028 \mathrm{E}+01$ & $1.48 \mathrm{E}+02$ \\
\hline Hydroxylapatite & $8.697 \mathrm{E}-01$ & $8.49 \mathrm{E}+00$ & $1.192 \mathrm{E}+01$ & $1.16 \mathrm{E}+02$ \\
\hline Sanidine & $5.930 \mathrm{E}+00$ & $3.21 \mathrm{E}+01$ & $8.128 \mathrm{E}+01$ & $4.40 \mathrm{E}+02$ \\
\hline Anorthite & $1.331 \mathrm{E}+01$ & $7.20 \mathrm{E}+01$ & $1.824 \mathrm{E}+02$ & $9.86 \mathrm{E}+02$ \\
\hline Albite & $1.474 \mathrm{E}+01$ & $7.51 \mathrm{E}+01$ & $2.021 \mathrm{E}+02$ & $1.03 \mathrm{E}+03$ \\
\hline Nepheline & $2.547 \mathrm{E}+00$ & $7.03 \mathrm{E}+00$ & $3.491 \mathrm{E}+01$ & $9.64 \mathrm{E}+01$ \\
\hline Hedenbergite & $5.622 \mathrm{E}+00$ & $2.71 \mathrm{E}+01$ & $7.706 \mathrm{E}+01$ & $3.72 \mathrm{E}+02$ \\
\hline Enstatite & $1.689 \mathrm{E}+01$ & $3.30 \mathrm{E}+01$ & $2.315 \mathrm{E}+02$ & $4.52 \mathrm{E}+02$ \\
\hline
\end{tabular}

NOTE: Calculated in "basalt-separated.xIs" in Attachment III (Disc 1)

Another case involves decreasing the surface area in the case by 10 . These values are taken as 0.1 times the surface area values in Table 6.4. 
To find the flow rate at which the incoming water is unaffected by reaction with the basalt, 3 cases were run which increased the flow rate of the water from that listed in Section 6.5.3.1. These rates include fluxes of $25 \mathrm{~mm} /$ year $(1.079 \mathrm{E}-08 \mathrm{moles} / \mathrm{sec}), 50 \mathrm{~mm} / \mathrm{year}(2.158 \mathrm{E}-08$ moles $/ \mathrm{sec})$, and $100 \mathrm{~mm} /$ year (4.315E-08 moles $/ \mathrm{sec})$.

For EQ3 and EQ6 runs, trace concentrations of elements are added to Bin 8 seepage water, Bin 11 seepage water and $\mathrm{J}-13$ well water composition that are not in the original composition, but are in the composition of the basalt. This is to ensure numerical stability in EQ6 runs. The trace elements added are found in Table 6-8.

Table 6-8. Elements Added as "Trace" to Water

\begin{tabular}{|c|c|c|c|c|}
\hline $\mathrm{Ti}^{\mathrm{a}}$ & $\mathrm{P}^{\mathrm{a}}$ & $\mathrm{Mn}^{\mathrm{a}}$ & $\mathrm{Al}^{\mathrm{b}}$ & $\mathrm{Fe}^{\mathrm{b}}$ \\
NOTES:
\end{tabular}
${ }^{\mathrm{b}}$ Added to all three water types as trace.
Added only to $\mathrm{J}-13$ well water as trace.

During EQ6 simulations, upon reaction with basalt, mineral phases precipitate from solution into the fractures within the basalt. Several minerals are suppressed from forming in the EQ6 runs because, though thermodynamically favored, they are kinetically unlikely to form upon reaction of water with cooled basalt. The following minerals were suppressed (not allowed to form) in all EQ6 runs:

\begin{tabular}{|c|c|c|c|}
\hline Quartz & Tridymite & Phlogopite & Annite \\
\hline & Dolomite & Dolomite-dis & Dolomite-ord \\
\hline
\end{tabular}

The micas (muscovite, annite, celadonite, and phlogopite), quartz, and tridymite are high temperature $\left(>500^{\circ} \mathrm{C}\right)$ minerals (Roberts et al. 1990) and are not expected to form. Celadonite can form at low temperatures, but this is due to either diagenesis of pre-existing material, very low grade metamorphic processes, or concentration of the liquid environment through evaporation (Li, Peacor, et al. 1997; Li, Lowenstein, and Blackburn 1997), so celadonite is not expected to form. Dolomite is usually derived by secondary mineralization. Since it rarely occurs as a primary mineral, it was also suppressed. (Klein and Hurlbut 1999).

\subsubsection{Sensitivity Cases}

Two different water types were used for the sensitivity analysis. The EQ6 input file compositions of Bin 11 seepage-water and J-13 well water (from EQ3NR output) are presented in Table 6-9. 
Table 6-9. Water Composition Used in the EQ3/6 Input Files of Water/Basalt Interaction for Sensitivity Cases

\begin{tabular}{|c|c|c|c|c|c|}
\hline \multicolumn{6}{|c|}{ EQ6 Input File Composition } \\
\hline \multicolumn{3}{|c|}{ Bin11 Seepage Water } & \multicolumn{3}{|c|}{ J-13 Well Water } \\
\hline Element & Concentration & Units & Element & Concentration & Units \\
\hline $\mathrm{pH}$ & 8.00 & $\mathrm{pH}$ & $\mathrm{pH}$ & 8.1 & $\mathrm{pH}$ \\
\hline $\mathrm{Na}$ & $4.78 \mathrm{E}-03$ & Moles/kg & $\mathrm{Na}$ & $1.99 \mathrm{E}-03$ & Moles $/ \mathrm{kg}$ \\
\hline Si & 1.19E-02 & Moles/kg & $\mathrm{Si}$ & 1.02E-03 & Moles $/ \mathrm{kg}$ \\
\hline $\mathrm{Ca}$ & 3.34E-04 & Moles/kg & $\mathrm{Ca}$ & $3.24 \mathrm{E}-04$ & Moles/kg \\
\hline $\mathrm{K}$ & 7.49E-04 & Moles $/ \mathrm{kg}$ & $\mathrm{K}$ & 1.29E-04 & Moles $/ \mathrm{kg}$ \\
\hline $\mathrm{Mg}$ & $6.34 \mathrm{E}-06$ & Moles $/ \mathrm{kg}$ & $\mathrm{Mg}$ & 8.27E-05 & Moles/kg \\
\hline $\mathrm{O}$ & $5.55 \mathrm{E}+01$ & Moles $/ \mathrm{kg}$ & 0 & $5.55 \mathrm{E}+01$ & Moles $/ \mathrm{kg}$ \\
\hline c & $5.62 \mathrm{E}-04$ & Moles/kg & c & $2.07 \mathrm{E}-03$ & Moles/kg \\
\hline $\mathrm{F}$ & $1.38 \mathrm{E}-03$ & Moles $/ \mathrm{kg}$ & $\mathrm{F}$ & $1.15 \mathrm{E}-04$ & Moles $/ \mathrm{kg}$ \\
\hline $\mathrm{Cl}$ & 1.30E-03 & Moles $/ \mathrm{kg}$ & $\mathrm{Cl}$ & $2.01 \mathrm{E}-04$ & Moles $/ \mathrm{kg}$ \\
\hline $\mathrm{N}$ & $1.26 \mathrm{E}-04$ & Moles/kg & $\mathrm{N}$ & $1.42 \mathrm{E}-04$ & Moles/kg \\
\hline S & 7.30E-04 & Moles/kg & S & $1.92 E-04$ & Moles/kg \\
\hline $\mathrm{Al}$ & $1.42 \mathrm{E}-09$ & Moles $/ \mathrm{kg}$ & $\mathrm{Al}$ & $1.00 \mathrm{E}-16$ & Moles/kg \\
\hline $\mathrm{Fe}$ & $2.08 \mathrm{E}-12$ & Moles $/ \mathrm{kg}$ & $\mathrm{Fe}$ & $1.00 \mathrm{E}-16$ & Moles/kg \\
\hline $\mathrm{P}$ & $1.00 \mathrm{E}-16$ & Moles $/ \mathrm{kg}$ & $P$ & $1.00 \mathrm{E}-16$ & Moles/kg \\
\hline $\mathrm{Mn}$ & $1.00 \mathrm{E}-16$ & Moles $/ \mathrm{kg}$ & $\mathrm{Mn}$ & $1.00 \mathrm{E}-16$ & Moles $/ \mathrm{kg}$ \\
\hline $\mathrm{Ti}$ & $1.00 \mathrm{E}-16$ & Moles $/ \mathrm{kg}$ & $\mathrm{Ti}$ & $1.00 \mathrm{E}-16$ & Moles $/ \mathrm{kg}$ \\
\hline
\end{tabular}

NOTE: These values are the output from EQ3NR for input into EQ6 input files. Input values for EQ3NR are located in Table 4-10.

\subsubsection{EQ6 Nomenclature for Water/Basalt Cases}

The name for EQ6 cases contains various numbers and letters describing the inputs into that particular case. This nomenclature is defined here.

The first part of the EQ6 case names is indicative of the water type reacted with the basalt indicated with:

- $\mathrm{b} 11=$ Bin 11 Seepage Water, $\mathrm{b8}=$ Bin 8 Seepage Water, and $\mathrm{j} 13=\mathrm{J}-13$ well water.

The letter in the file name immediately following the water type is indicative of the conditions in which the run was carried out as indicated below:

- $\mathrm{b}=$ base case where saturation $=0.1$, flux $=0.4 \mathrm{~mm} /$ year, pore fraction $=0.17$, and the basalt is fractured into meter sized particles.

- $\mathrm{p}=$ pore fraction of base case changed to 0.13 .

- $\mathrm{a}=$ surface area of minerals available for reaction decreased to 0.1 times surface area of the base case. 
- $\mathrm{s}=$ saturation of base case changed to 1.0 .

- $\mathrm{fl}=$ flux rate of base case changed to $3.8 \mathrm{~mm} / \mathrm{year}$.

- $\mathrm{f} 2=$ flux rate of base case changed to $11.7 \mathrm{~mm} / \mathrm{year}$.

To find the flow rate at which the incoming water is unaffected by reaction with the basalt, 3 cases were run which increased the flow rate of the water from that listed above for the abstraction. These cases, like those above, are indicated by the letter in the file name immediately following the water type. These include:

- $\mathrm{f3}=$ flux rate of base case changed to $25 \mathrm{~mm} / \mathrm{year}$.

- $\mathrm{f} 4$ = flux rate of base case changed to $50 \mathrm{~mm} / \mathrm{year}$.

- $\mathrm{f} 5=$ flux rate of base case changed to $100 \mathrm{~mm} / \mathrm{year}$.

The next set of letters is simply indicative of the ordering of consecutive runs. In several instances, cases did not reach the 20,000 year mark in 30,000 EQ6 time steps. In order to keep files small and manageable, these cases were broken up into several cases. The first step in these cases is indicated by an "." as are all those cases in which the run went to completion in 30,000 time steps. The letters $\mathrm{x}, \mathrm{y}, \mathrm{z}, \mathrm{q}, \mathrm{r}$, and $\mathrm{s}$ indicate the consecutive files with $\mathrm{x}$ directly following "", $y$ following $x$ and so on.

The final set of letters in the case name is indicative of the $\mathrm{CO}_{2}$ fugacity with which the water was reacted as indicated by:

- $2=\mathrm{fCO}_{2}$ of $10^{-2}$ bar, $25=\mathrm{fCO}_{2}$ of $10^{-2.5}$ bar, $3=\mathrm{fCO}_{2}$ of $10^{-3}$ bar, $35=\mathrm{fCO}_{2}$ of $10^{-3.5}$ bar, $4=\mathrm{fCO}_{2}$ of $10^{-4}$ bar

\subsubsection{Results of EQ6 Simulations of Crown Seepage Water Reaction with Cooled Basalt}

Due to the large amount of output generated through the EQ6 simulations of crown seepage water reaction with cooled basalt in an emplacement drift, these files are located on Attachment III (Disc 1 and 2). The results of the abstraction of values ( $\mathrm{pH}$, ionic strength, $\mathrm{fO}_{2}$, and $\mathrm{fCO}_{2}$ ) for use in TSPA-LA can be found in Section 6.7.2.

\subsection{DISCUSSION OF UNCERTAINTIES}

The inferences, assumptions, and the results presented in this model report are based on the conceptual models (base-case and alternative) which describe a hypothetical igneous intrusive event and associated processes and conditions that could occur in the repository. Given the nature of the events and processes associated with an igneous intrusion scenario, the prediction of impacts on the repository system and, in particular, on the waste packages and waste forms is complex. To compensate for uncertainties, the model simulations and analyses are based on conservative assumptions and bounding parameter values, and supported by corroborative natural and industrial analogs and experimental results. 


\subsubsection{Uncertainty in Heat Conduction Analysis}

The range of thermal conductivities for wet and dry conditions for the four units (Tptpul, Tptpmn, Tptpll, and Tptpln) is considered large enough to bound uncertainty in the results of radial heat conduction simulations. While detailed analyses have not been performed, it is likely, based on Figures 6-1 and 6-2, that temperatures would exceed the boiling point of water only within the first few meters from the drift, and that the temperature of most of the rock would remain below boiling. A source of uncertainty derives from the fact that the thermal conductivity of the solid phase is several times larger than the thermal conductivity of water. Since the thermal gradients within the pore space are more likely to be influenced by liquid water, the effective thermal gradients for a uniform heat flux would be higher. The volumetric heat capacity is reduced with a reduction in saturation or water content because water with a high specific heat is substituted for air with a low specific heat capacity. Theoretical considerations indicate that the thermal gradients are much higher, depending on the spatial variations in the properties of the rock media between the drifts. Additionally, the idea that the magma is subject to constant heat content ignores any heat that may be generated by exothermic reactions. Though this heat is expected to be small compared to the heat of the magma, it is, nonetheless, a source of uncertainty.

A detailed sensitivity analysis is shown in Attachment I. This analysis provides information on the percent contribution values of each model component to the heat conduction/flow system variance. The sensitivity of the heat flow model to the uncertainty in key inputs was investigated using the Delta Method, as described in Attachment I. The variance shows that the resulting peak temperature at a distance of $10 \mathrm{~m}$ is sensitive only to the initial temperature. Therefore, the uncertainty in the initial temperature was used to calculate its variance, and that change in the peak temperature, $\pm 3^{\circ} \mathrm{C}$, sampled as a uniform distribution, is used as the uncertainty in the temperature output provide in Tables 6-12 and 8-1.

\subsubsection{Uncertainty in the Geochemical Modeling Using EQ6}

\subsubsection{Uncertainty in EQ6 Inputs}

Uncertainties in input values related to geochemical modeling using the EQ6 code for the base case include: pore fraction, reactive surface area of materials, flow rate of water through the basalt, saturation, composition of oxides that make up the basalt, $\mathrm{CO}_{2}$ and $\mathrm{O}_{2}$ fugacity, and type of water flowing through the basalt (water types investigated are presented in Table 4-8 and Table 4-10). Several of these parameters are included in cases which were used in the $\mathrm{pH}$ abstractions and are thus already incorporated into the model output. These parameters, as well as the range of values used, are:

- Pore Fraction: 0.13 through 0.17 .

- Flux: $0.4 \mathrm{~mm} /$ year through $11.7 \mathrm{~mm} /$ year.

- Surface Area: all surfaces are available and 10 percent of all surfaces available.

- Saturation: 0.1 through 1.0.

- $\log \mathrm{fCO}_{2}:-2$ through -4 bar 
The composition of oxides that make up the basalt was taken from BSC 2003 [DIRS:166407], Table 6. These values are derived in BSC 2003 [DIRS:166407] from 45 samples collected from the Lathrop Wells Cone. Materials from the Lathrop Wells Cone represent the most recent eruptive event ( 0.3 million years, Vaniman et al. 1982) in the Yucca Mountain region. Therefore it may better represent the composition of the hypothetical igneous intrusion than older volcanic centers in the area ranging in age from approximately 1.1 million to 3.7 million years (Vaniman et al. 1982). The composition of the Lathrop Wells Cone along with corresponding uncertainty is presented in Table 6-10.

Table 6-10. Composition of Lathrop Wells Cone Basalt

\begin{tabular}{|c|c|c|c|c|c|}
\hline \multicolumn{7}{|c|}{ Basalt Composition } \\
\hline Oxide & Mean Wt\% & $\begin{array}{c}\text { Standard } \\
\text { Deviation }\end{array}$ & Oxide & Mean Wt\% & $\begin{array}{c}\text { Standard } \\
\text { Deviation }\end{array}$ \\
\hline $\mathrm{SiO}_{2}$ & 48.5 & 0.58 & $\mathrm{~K}_{2} \mathrm{O}$ & 1.84 & 0.04 \\
\hline $\mathrm{Al}_{2} \mathrm{O}_{3}$ & 16.74 & 0.22 & $\mathrm{TiO}_{2}$ & 1.93 & 0.06 \\
\hline $\mathrm{Fe}_{2} \mathrm{O}_{3}$ & 1.74 & 0.03 & $\mathrm{P}_{2} \mathrm{O}_{5}$ & 1.22 & 0.03 \\
\hline $\mathrm{MgO}$ & 5.83 & 0.11 & $\mathrm{MnO}$ & 0.17 & 0.00 \\
\hline $\mathrm{CaO}$ & 8.6 & 0.22 & $\mathrm{FeO}$ & 8.9 & 0.17 \\
\hline $\mathrm{Na}_{2} \mathrm{O}$ & 3.53 & 0.09 & & & \\
\hline
\end{tabular}

Source: BSC 2003 [DIRS:166407], Table 7

Because of the small deviations from the mean, any differences arising in water chemistry from basalt water interactions with a slightly different basalt composition would be very small due to the low dissolution rates of basaltic minerals. Therefore, no change to the water chemistry from that presented for reaction with mean basalt composition is expected.

The abstracted minerals used in the simulations were derived by manipulation of the oxide chemical composition of the basalt taken from Characterize Eruptive Processes at Yucca Mountain, Nevada (BSC 2003 [DIRS:166407]) to reflect, as much as possible, the modal mineral composition of Crater Flat basalt, specifically, the Lathrop Wells Cone. Vaniman et al. (1982) indicates that the groundmass is primarily plagioclase, pyroxene, and olivine with olivine phenocrysts (up to 3\%). Perry and Straub (1996) indicate a composition of plagioclase, olivine, titanomagnetite, and clinopyroxene with olivine and plagioclase phenocrysts. Plagioclase phenocrysts are found primarily in chronostratigraphic unit I and largely absent from chronostratigraphic units II, III, and IV (See Perry and Straub 1996 for definition of units).

The normative composition was necessary over the strictly modal composition of Lathrop Wells Cone basalt primarily due to database constraints Some of these include:

- In the EQ6 database, not all minerals belonging to a series are included, only the endmembers.

- Mineral chemical formulas are dictated by composition in the data base (ie. even though magnetite at the Lathrop Wells Cone contains significant $\mathrm{Ti}$, the database uses the formula of $\mathrm{Fe}_{3} \mathrm{O}_{4}$ in calculations.)

Several minerals were also included in the normative analysis that have not been specifically cited at the Lathrop Wells Cone. These include nepheline, sanidine, apatite, and ilmenite. The 
oxide components of these minerals can all be found in other minerals or glass that are part of the groundmass. The reasons for their use in the normative are outlined in Section 6.5.3.

Since titanomagnetite is not included in the database, magnetite and ilmenite were used in its place. The use of these two minerals in EQ6 cases over titanomagnetite does not effect the abstracted results as they have no effect on the $\mathrm{pH}$ of the system, the $\mathrm{Fe}$ and $\mathrm{Ti}$ components being taken almost immediately into secondary minerals.

The composition of any glass within the Lathrop Wells Cone is not well documented. The $\mathrm{K}_{2} \mathrm{O}$ and $\mathrm{P}_{2} \mathrm{O}_{5}$ used in the normative analysis for hydroxylapatite and sanidine may be contained within glass. Some basaltic glasses are known to be very resistant to dissolution while other dissolves quite readily. The durability of glass is due primarily to its composition. Without a firm knowledge of that composition, it is hard to determine the durability of glasses at the Lathrop Wells Cone.

Basalt glasses have been used in a number of references for natural analogues to the dissolution of nuclear waste glasses (as shown in Section 7.3 of BSC 2004 [DIRS: 167619]). BSC 2004 [DIRS: 167619] indicates that the rate expressions for defense HLW glass Degradation bounds the long term dissolution rates of basalt glass. The "most likely" rate presented in BSC 2004 [DIRS: 167619] for the $\mathrm{pH}$ range of interest (between 6.7 and 10.1 from Hearn et al., 1985 and DOE 1982) is lower than the dissolution rates of the minerals used in the EQ6 calculations. If glass composes a significant portion of the groundmass, this would effectively lower the $\mathrm{pH}$ of the water percolating through the basalt than that calculated in the abstraction. The maximum glass rate presented in BSC 2004 [DIRS: 167619] is within the same range of dissolution of the less durable minerals used within EQ6 calculations (such as hydroxylapatite). This may raise the $\mathrm{pH}$ slightly, but the exact amount is not known.

The abstraction results (using the normative minerals) provided in Table 8-2 have been validated using natural analogue studies on the chemical characteristics of basalt ground water. They are therefore considered valid and appropriate for use.

The base-case water type reacted with the basalt was Bin 8 seepage water from DTN: MO0310SPAEBSCB.003. To determine the effects that other water types had on the $\mathrm{pH}$, ionic strength, and fluoride content of water reacted with basalt, the base-case EQ6 run (see Section 6.5.3.3 for definition of this run) was run with Bin 11 seepage water from DTN: MO0310SPAEBSCB.003 and J-13 well water from DTN: MO0006J13WTRCM.000. These two water types represent seepage waters that are: 1) more concentrated, and 2) more dilute than the Bin 8 seepage water. The EQ6 output (Spreadsheet "sensitivity.xls" on Attachment III, Disc 1) shows that the values for ionic strength and $\mathrm{pH}$ for the three water types are very similar. Therefore, the type of water percolating through the basalt will not have an impact on the final reacted water chemistry.

The EQ6 cases for this report were run at atmospheric oxygen condition for the repository horizon $\left(\log \mathrm{f}_{\mathrm{O} 2}=-0.7\right.$ bar). and at $\log \mathrm{f}_{\mathrm{CO} 2}$ between -2 and -4 bar. To use the solubility look-up table in Dissolved Concentration Limits of Radioactive Elements (BSC 2003 [DIRS:163152]), a constant value for these parameters must be used for any abstraction. 


\subsubsection{Uncertainty in EQ6 Outputs}

The water chemistry parameters required for use in TSPA are temporal values for $\mathrm{pH}$, ionic strength, and fluoride content. As pointed out in Section 6.7.2, many EQ6 simulations of basalt/water interactions show no change in fluoride content. Therefore, the fluoride content of the aqueous fluid is dependent solely on the content that is already in the fluid as it contacts the basalt. The temporal variation of $\mathrm{pH}$ and ionic strength along with corresponding uncertainty in the form of maximum and minimum values are presented in Table 6-11.

Values were obtained by first calculating a time-weighted average for each case in the abstraction. The minimum and maximum of these time-weighted averages are then presented in Table 6-11. Time-weighted averages were used due to the large time steps used in TSPA calculations.

Table 6-11. Temporal Maximum and Minimum Values for $\mathrm{pH}$ and lonic Strength

\begin{tabular}{|c|c|c|c|c|}
\hline \multicolumn{5}{|c|}{$\log \mathrm{fCO}_{2}=-2$ bar } \\
\hline & \multicolumn{2}{|c|}{ pH } & \multicolumn{2}{|c|}{ lonic Strength (moles $/ \mathrm{kg}$ ) } \\
\hline Time Period* & Maximum & Minimum & Maximum & Minimum \\
\hline$x \leq 25$ years & 7.9 & 7.6 & 1.87E-02 & $9.64 \mathrm{E}-03$ \\
\hline $25>x \leq 250$ years & 8.1 & 7.8 & $3.59 \mathrm{E}-02$ & 1.23E-02 \\
\hline $250>x \leq 2500$ years & 8.1 & 7.8 & $4.00 \mathrm{E}-02$ & $1.22 \mathrm{E}-02$ \\
\hline $2500>x \leq 20000$ years & 8.1 & 7.7 & $3.58 \mathrm{E}-02$ & $1.15 \mathrm{E}-02$ \\
\hline \multicolumn{5}{|c|}{$\log \mathrm{fCO}_{2}=-2.5 \mathrm{bar}$} \\
\hline & \multicolumn{2}{|c|}{$\mathrm{pH}$} & \multicolumn{2}{|c|}{ lonic Strength (moles/kg) } \\
\hline Time Period* & Maximum & Minimum & Maximum & Minimum \\
\hline$x \leq 25$ years & 8.4 & 8.1 & 2.09E-02 & 9.23E-03 \\
\hline $25>x \leq 250$ years & 8.6 & 8.3 & 4.33E-02 & $1.31 \mathrm{E}-02$ \\
\hline $250>x \leq 2500$ years & 8.6 & 8.3 & $5.50 \mathrm{E}-02$ & 1.29E-02 \\
\hline $2500>x \leq 20000$ years & 8.6 & 8.2 & 4.22E-02 & 1.18E-02 \\
\hline \multicolumn{5}{|c|}{$\log \mathrm{fCO}_{2}=-3$ bar } \\
\hline & \multicolumn{2}{|c|}{$\mathrm{pH}$} & \multicolumn{2}{|c|}{ lonic Strength (moles $/ \mathrm{kg}$ ) } \\
\hline Time Period* & Maximum & Minimum & Maximum & Minimum \\
\hline$x \leq 25$ years & 8.9 & 8.6 & 2.43E-02 & 9.14E-03 \\
\hline $25>x \leq 250$ years & 9.0 & 8.8 & $6.85 \mathrm{E}-02$ & $1.40 \mathrm{E}-02$ \\
\hline $250>x \leq 2500$ years & 9.1 & 8.8 & $8.85 \mathrm{E}-02$ & 1.37E-02 \\
\hline $2500>x \leq 20000$ years & 9.1 & 8.7 & 8.79E-02 & 1.19E-02 \\
\hline \multicolumn{5}{|c|}{$\log \mathrm{fCO}_{2}=-3.5 \mathrm{bar}$} \\
\hline & \multicolumn{2}{|c|}{$\mathrm{pH}$} & \multicolumn{2}{|c|}{ lonic Strength (moles $/ \mathrm{kg}$ ) } \\
\hline Time Period ${ }^{*}$ & Maximum & Minimum & Maximum & Minimum \\
\hline$x \leq 25$ years & 9.4 & 9.0 & $3.00 \mathrm{E}-02$ & $9.44 \mathrm{E}-03$ \\
\hline $25>x \leq 250$ years & 9.5 & 9.2 & $9.78 \mathrm{E}-02$ & 1.67E-02 \\
\hline $250>x \leq 2500$ years & 9.6 & 9.2 & $1.60 \mathrm{E}-01$ & $1.62 \mathrm{E}-02$ \\
\hline $2500>x \leq 20000$ years & 9.5 & 9.1 & 9.65E-02 & $1.30 \mathrm{E}-02$ \\
\hline
\end{tabular}


Table 6-11 (Continued). Temporal Maximum and Minimum Values for $\mathrm{pH}$ and lonic Strength

\begin{tabular}{|c|c|c|c|c|}
\hline \multicolumn{5}{|c|}{ Log $\mathrm{fCO}_{2}=-4$ bar } \\
\hline & \multicolumn{2}{|c|}{$\mathrm{pH}$} & \multicolumn{2}{c|}{ lonic Strength (moles/kg) } \\
\hline Time Period & Maximum & Minimum & Maximum & Minimum \\
\hline $\mathrm{x} \leq 25$ years & 9.7 & 9.4 & $3.42 \mathrm{E}-02$ & $1.02 \mathrm{E}-02$ \\
\hline $25>\mathrm{x} \leq 250$ years & 9.9 & 9.6 & $1.17 \mathrm{E}-01$ & $1.97 \mathrm{E}-02$ \\
\hline $250>\mathrm{x} \leq 2500$ years & 9.9 & 9.6 & $1.86 \mathrm{E}-01$ & $1.89 \mathrm{E}-02$ \\
\hline $2500>\mathrm{x} \leq 20000$ years & 9.9 & 9.6 & $1.07 \mathrm{E}-01$ & $1.43 \mathrm{E}-02$ \\
\hline
\end{tabular}

Source: Calculated in Spreadsheets "abstraction-2.xls", "abstraction-25.xls", "abstraction-3.xls", "abstraction-35.xIs, and "abstraction-4.xIs" in Attachment III (Disc 1 and 2)

NOTE: * Time period represents time after re-establishment of seepage flow. " $\mathrm{x}$ " = "time"

\subsection{IMPLEMENTATION OF IGNEOUS INTRUSION MODEL FOR TSPA-LA}

\subsubsection{Igneous Intrusion Impacts on Zone 1 Materials}

Section 6.5.1 describes the basis for the conservative conclusion that the igneous intrusion would render the drip shields, waste packages, and cladding in the Zone 1 emplacement drifts ineffective so they would provide no further protection to the waste forms. Because the waste is considered chemically unchanged in the base case model, the dissolved concentration of radioelements in water in the basalt, due to reactions with the waste, would have the same dependency on water chemistry as does waste dissolving in the nominal case. Thus, the solubility tables given in Dissolved Concentration Limits of Radioactive Elements (BSC 2003 [DIRS:163152]) are appropriate to determine concentrations of radionuclides in water in basaltfilled emplacement drifts.

For the waste packages in Zone 1 are enclosed within the magma body, the temperature of the internal waste forms can be considered to be the same as the temperature of the cooling magma. These values are presented in the lookup-table (Table 6-12) for magma cooling temperatures (for $T_{r=0 m}$ ). The temperature of the invert can also be taken from Table 6-12 for temperatures at a radius of 3 meters from the center of the magma filled drift $\left(T_{r=3 m}\right)$. Because of the rapid change in temperature early in time, the temperatures for times between zero and the length of the TSPA time step (in years) should be sampled uniformly. The temperatures for times greater than the TSPA time step but less than 100 years should be taken directly from Table 6-12. The uncertainty in the temperature, as indicated in Section 6.6 .1 , is $\pm 3^{\circ} \mathrm{C}$ for the temperature output. These values are warehoused in DTN: MO0402SPAHWCIG.002. 
Table 6-12. Temperature of Waste Forms Inside Intruded Magma Body

\begin{tabular}{|c|c|c|c|c|c|c|c|c|c|c|}
\hline \multirow{2}{*}{$\begin{array}{c}\text { Time (t) } \\
\text { Years }{ }^{*}\end{array}$} & \multicolumn{2}{|c|}{$\begin{array}{c}\text { For an Intrusion } \\
\text { into a Repository } \\
\text { at } 25^{\circ} \mathrm{C}\end{array}$} & \multicolumn{2}{|c|}{$\begin{array}{c}\text { For an Intrusion } \\
\text { into a Repository } \\
\text { at } 50^{\circ} \mathrm{C}\end{array}$} & \multicolumn{2}{|c|}{$\begin{array}{c}\begin{array}{c}\text { For an Intrusion } \\
\text { into a Repository } \\
\text { at } 100^{\circ} \mathrm{C}\end{array} \\
\end{array}$} & \multicolumn{2}{|c|}{$\begin{array}{c}\text { For an Intrusion } \\
\text { into a Repository } \\
\text { at } 150^{\circ} \mathrm{C}\end{array}$} & \multicolumn{2}{|c|}{$\begin{array}{c}\begin{array}{c}\text { For an Intrusion } \\
\text { into a Repository } \\
\text { at } 200^{\circ} \mathrm{C}\end{array} \\
\end{array}$} \\
\hline & $T_{r=0 m}$ & $T_{r=3 m}$ & $T_{r=0 m}$ & $T_{r=3 m}$ & $T_{r=0 m}$ & $T_{r=3 m}$ & $T_{r=0 m}$ & $T_{r=3 m}$ & $T_{r=0 m}$ & $T_{r=3 m}$ \\
\hline 0 & 1150 & 1150 & 1150 & 1150 & 1150 & 1150 & 1150 & 1150 & 1150 & 1150 \\
\hline 0.1 & 977 & 592 & 1006 & 620 & 1012 & 644 & 1019 & 668 & 1026 & 692 \\
\hline 0.2 & 702 & 462 & 749 & 494 & 768 & 524 & 786 & 553 & 804 & 583 \\
\hline 0.3 & 530 & 382 & 577 & 416 & 603 & 449 & 629 & 483 & 655 & 516 \\
\hline 0.4 & 422 & 326 & 467 & 360 & 498 & 396 & 529 & 432 & 560 & 468 \\
\hline 0.5 & 351 & 284 & 394 & 318 & 428 & 356 & 462 & 394 & 497 & 431 \\
\hline 0.6 & 301 & 252 & 341 & 286 & 378 & 325 & 415 & 364 & 452 & 403 \\
\hline 0.7 & 264 & 226 & 303 & 260 & 341 & 300 & 380 & 341 & 418 & 381 \\
\hline 0.8 & 236 & 206 & 273 & 239 & 313 & 281 & 353 & 322 & 392 & 363 \\
\hline 0.9 & 213 & 189 & 249 & 222 & 290 & 264 & 331 & 306 & 372 & 349 \\
\hline 1 & 195 & 175 & 230 & 208 & 272 & 251 & 314 & 293 & 356 & 336 \\
\hline 2 & 111 & 106 & 142 & 136 & 187 & 182 & 233 & 228 & 279 & 274 \\
\hline 3 & 82.8 & 80.4 & 111 & 109 & 158 & 156 & 206 & 203 & 253 & 251 \\
\hline 4 & 68.4 & 67.0 & 96.0 & 94.5 & 144 & 142 & 192 & 190 & 240 & 238 \\
\hline 5 & 59.7 & 58.9 & 86.8 & 85.8 & 135 & 134 & 183 & 183 & 232 & 231 \\
\hline 6 & 54.0 & 53.4 & 80.7 & 80.0 & 129 & 129 & 178 & 177 & 227 & 226 \\
\hline 7 & 49.8 & 49.4 & 76.3 & 75.8 & 125 & 125 & 174 & 173 & 223 & 222 \\
\hline 8 & 46.7 & 46.4 & 73.0 & 72.6 & 122 & 122 & 171 & 171 & 220 & 220 \\
\hline 9 & 44.3 & 44.0 & 70.5 & 70.2 & 120 & 119 & 169 & 168 & 218 & 217 \\
\hline 10 & 42.4 & 42.2 & 68.4 & 68.2 & 118 & 117 & 167 & 167 & 216 & 216 \\
\hline 20 & 33.7 & 33.6 & 59.2 & 59.2 & 109 & 109 & 158 & 158 & 208 & 208 \\
\hline 30 & 30.8 & 30.8 & 56.1 & 56.1 & 106 & 106 & 156 & 156 & 205 & 205 \\
\hline 30 & 29.3 & 29.3 & 54.6 & 54.6 & 104 & 104 & 154 & 154 & 204 & 204 \\
\hline 50 & 28.5 & 28.5 & 53.7 & 53.7 & 104 & 104 & 153 & 153 & 203 & 203 \\
\hline 60 & 27.9 & 27.9 & 53.1 & 53.1 & 103 & 103 & 153 & 153 & 203 & 203 \\
\hline 70 & 27.5 & 27.5 & 52.6 & 52.6 & 103 & 103 & 152 & 152 & 202 & 202 \\
\hline 80 & 27.2 & 27.2 & 52.3 & 52.3 & 102 & 102 & 152 & 152 & 202 & 202 \\
\hline 90 & 26.9 & 26.9 & 52.0 & 52.0 & 102 & 102 & 152 & 152 & 202 & 202 \\
\hline 100 & 26.7 & 26.7 & 51.8 & 51.8 & 102 & 102 & 152 & 152 & 202 & 202 \\
\hline
\end{tabular}

Source: Calculated in spreadsheets in Attachment III (Disc 1, "Heat" folder)

NOTES: $T_{r=0}$ is the centerline temperature and $T_{r=3}$ is the temperature at the edge of the dike.

*Time ( $\mathrm{t}$ ) represents time from the igneous intrusive event.

\subsubsection{Crown Seepage Reaction with Cooled Basalt}

The chemistry of water seeping into Zone 1 drifts is considered to be the same as if there had been no intrusion. However, the chemistry of the incoming seepage may be affected by basaltwater reactions within the drift. The effects of these reactions on a typical crown seepage water have been modeled (Section 6.5.3). Table 6-11 in Section 6.6.2.2 shows the abstracted values for minimum and maximum $\mathrm{pH}$ and ionic strength. A comparative water type for use in validation of 
ionic strength values derived by EQ6 could not be found for values of ionic strength. Since these upper values of ionic strength cannot be validated, this model recommends using the upper bound of waste form colloid stability presented in Waste Form and In-Drift Colloids-Associated Radionuclide Concentrations: Abstraction and Summary (BSC 2003 [DIRS: 166845], Table 17) in cases where the maximum ionic strength exceeds 0.05 moles $/ \mathrm{kg}$. Since this value $(0.05$ moles $/ \mathrm{kg}$ ) represents the upper bound at which waste colloids are stable, it is conservative in that it allows colloids to remain stable. These values are presented in Table 8-2. The output water chemistry parameters ionic strength and $\mathrm{pH}$ are warehoused in DTN: MO0402SPAHWCIG.002.

The values presented in Tables 8-2 (from Table 6-11) do not represent an absolute range, but the range of values for the parameters expressed in Section 6.6.2.1. If those ranges were slightly modified, it is expected that the $\mathrm{pH}$ and ionic strength values may change slightly. Therefore, it is recommended that TSPA sample uniformly between the minimum and maximum values in Table 8-2.

Fluoride content of the water in contact with basalt is listed as one of the outputs of this model in Technical Work Plan for Waste Form Degradation Modeling, Testing, and Analyses in Support of $L A$ (BSC 2004 [DIRS:167796]). However, this parameter is not necessary to determine fuel dissolution rates per Dissolved Concentration Limits of Radioactive Elements (BSC 2003 [DIRS:163152] where it is presented as an uncertainty. Additionally, several EQ6 cases (see Attachment III, Disc 1 and 2, for output files) show that concentration can decrease from precipitation of mineral phases that contain fluorine $(F)$. However, this is highly dependent on the phosphorus content of the fluid. Many EQ6 simulations of basalt/water interactions show no change in fluoride content. Therefore, no abstraction of this parameter was completed. Should fluoride content be of future interest, the fluoride content used should be the initial fluoride content of the water entering the drift.

The EQ6 simulations of basalt/water interactions were carried out at atmospheric oxygen condition $\left(\log \mathrm{f}_{\mathrm{O} 2}=-0.7\right.$ bar) and $\log \mathrm{CO}_{2}$ fugacity values between -2 and -4 bar.

As the seepage water percolates through the basalt, the water would contact with waste forms. Formation of secondary mineral phases (commonly called rind) develop on the waste forms making the radionuclides available for release. Although rind volumes were not specifically calculated in this model report, it is important to discuss how the rind volume from nominal case scenarios relates to the igneous intrusion scenario. The rind volume for the commercial spent nuclear fuel waste form is described in Clad Degradation - Summary and Abstraction for LA (BSC 2003 [DIRS:162153]). This model accounts for rind volume of commercial spent nuclear fuel in both nominal and volcanic cases. In the volcanic case, no credit is taken for cladding so that the waste form rind volume is essentially modeled from the bare fuel. Rind volume for high level waste glass is discussed in Defense HLW Glass Degradation Model (BSC 2004 [DIRS:167619]). In this model report, the rind volume is obtained using bare glass logs without any protection from the steel glass pour canister. Since glass waste was modeled the same as the commercial spent nuclear fuel for the volcanic case, the rind volume for the glass is also considered appropriate for use in the igneous intrusion event. For the specifics on the rind volume and how they should be applied to the TSPA, refer to the individual model reports cited here: Clad Degradation - Summary and Abstraction for LA (BSC 2003 [DIRS:162153]) and Defense HLW Glass Degradation Model (BSC 2004 [DIRS: 167619]). 
In some instances, TSPA may need $\mathrm{pH}$ and ionic strength values for a range of parameters that are outside the range of validity of this model. These parameters include flux and $\log f \mathrm{CO}_{2}$. In the case of flux, it was observed in EQ6 calculations (see "rate comparison.xls" in Attachment III) that when a flux rate of $50 \mathrm{~mm} /$ year or greater was obtained, the output water composition was within $0.08 \mathrm{pH}$ units and $1.15 \mathrm{E}-03 \mathrm{moles} / \mathrm{kg}$ of the original $\mathrm{pH}$ and ionic strength values (i.e. Time $=0$ values). For this reason, a flux rate of $50 \mathrm{~mm} /$ year is chosen for TSPA as the point where the $\mathrm{pH}$ and ionic strength of the water (equilibrated with atmospheric gas levels) percolating into the basalt block equals the $\mathrm{pH}$ and the ionic strength of the water leaving the basalt block. For flux rates less than $50 \mathrm{~mm} /$ year, the values from Table 8-2 can be used. As shown in Dissolved Concentration Limits of Radioactive Elements (BSC 2003 [DIRS:163152]), the two most important parameters affecting the solubility of radioelements include $\mathrm{pH}$ and $\mathrm{fCO}_{2}$. Since $\mathrm{pH}$ decreases with increasing flux rate, using the values for flux between 0.4 and $11.7 \mathrm{~mm} /$ year for any cases where the flux is below $50 \mathrm{~mm} /$ year is conservative since the radionuclides will be more soluble at the higher $\mathrm{pH}$ values shown in Table 8-2.

Convergence difficulties arise in EQ6 calculations carried out at high $\mathrm{pH}$ and low $\mathrm{CO}_{2}$ levels. For this reason, the model includes $\log \mathrm{fCO}_{2}$ values only from -2 to -4 bar. For TSPA calculations where the $\log \mathrm{fCO}_{2}$ is between -4 and -5 bar, it is recommended that the values in Table 8-2 for $\log \mathrm{fCO}_{2}$ of -4 bar be used. Natural analogues (Hearn et al., 1985 and DOE 1982) show that the $\mathrm{pH}$ of water in contact with basalt (depending on the $\mathrm{CO}_{2}$ levels) can be between 6.7 and 10.1 with the majority of data showing $\mathrm{pH}$ values between 8.5 to almost 10 . Ionic strength is shown between $1.8 \mathrm{E}-02$ to a minimum of $7.4 \mathrm{E}-03$ moles $/ \mathrm{kg}$. Therefore the $\mathrm{pH}$ and ionic strength for $\log \mathrm{fCO}_{2}$ between -4 and -5 bar should, realistically, not be much greater than those presented in Table 8-2. For the upper end of the $\log \mathrm{fCO}_{2}$ range used by TSPA ( -1.7 bar), TSPA calculations should use the $\log \mathrm{fCO}_{2}$ values at -2 bar.

\section{MODEL VALIDATION}

The purpose of this process model is to assess the potential impacts of an igneous intrusion on waste packages and waste forms, including dynamic, thermal, hydrologic, and chemical impacts. This assessment constitutes the waste package and waste form impacts submodel of the TSPALA model assessing the impacts of a potential igneous intrusion event on system performance.

Technical Work Plan for Waste Form Degradation Modeling, Testing, and Analyses in Support of LA (BSC 2004 [DIRS:167796]) lists eight criteria, as required by AP-SIII.10Q, Section 5.4, to be used to determine whether the required level of confidence has been documented (BSC 2004 [DIRS:167796], Section 2.1.4.3).

The criteria from the technical work plan (BSC 2004 [DIRS:167796]) used to validate this model (in Section 7.1) are as follows:

Criterion One: Corroboration of model results with data acquired from the laboratory, field experiments, analog studies, or other relevant observations, not previously used to develop or calibrate the model.

Criterion Three: Corroboration with data published in referenced journals or literature. 
Criterion Eight: Demonstration that the model is conservative

The technical work plan (BSC 2004 [DIRS:167796]) defines the level of confidence by the number of criteria met to validate the model. At least one criterion must be met to show a required low level of confidence has been satisfied. High confidence is satisfied when more than one criterion is satisfied. As indicated in Section 2.1.4.4 of the technical work plan (BSC 2004 [DIRS:167796]), the Igneous Intrusion Impacts Model requires a medium level of confidence and, therefore, it is required to satisfy at least two criteria for model validation. The technical work plan (BSC 2004 [DIRS:167796]) Section 2.1.4.4 states that criteria 1 and 3 dealing with corroboration by laboratory analog, or field data and corroboration with published data are appropriate criteria for this model report. In addition, Criterion 8 is also applicable and will be discussed.

\subsection{CORROBORATION}

Have the model results been corroborated by data or other relevant observations that were not used to develop or calibrate the model?

In the assessment of potential impact of an igneous intrusion on the waste packages and waste forms in Zone 1 emplacement drifts, it was shown that the drip shields, cladding, and waste packages would be damaged, and fail to provide protection for the waste forms. The confidence in this conservative approach is augmented by corroborative information. Consideration of maximum service temperatures of Stainless Steel Type 304 and $316\left(925^{\circ} \mathrm{C}\right.$, Davison et al. 1987) and of Alloy 22 (about $1200^{\circ} \mathrm{C}$, Mankins and Lamb, 1998), suggest that, although the intrusive temperature $\left(1150^{\circ} \mathrm{C}\right)$ is lower than the melting points of stainless steel, the structural integrity of these engineered materials can be diminished upon an intrusive event. The intrusive temperature is right at the maximum service temperature of Alloy 22. Softening, creeping, and breaking down of engineered materials are expected at the intrusive temperature.

Yau and Webster (1987) indicate that zirconium forms a very protective $\mathrm{ZrO}_{2}$ film. However, above temperatures of $700^{\circ} \mathrm{C}$, it will absorb oxygen and become brittle. Hydrogen absorption can begin at $760^{\circ} \mathrm{C}$ also causing the metal to become brittle. Zirconium is also unstable in gases (such as $\mathrm{CO}, \mathrm{CO}_{2}$, and $\mathrm{SO}_{2}$ ) at temperatures above $400^{\circ} \mathrm{C}$ and in halides at about $200^{\circ} \mathrm{C}$. Therefore in the presence of corrosives at high magmatic temperatures, zirconium will become highly corroded.

Results of magma-metal/alloys compatibility tests, conducted in a volatile-rich rhyolite magma at $850^{\circ} \mathrm{C}$ and $15-200 \mathrm{MPa}$ pressures for durations of 1 hour to 30 days show trends of metal corrosion and on the reaction of metals in contact with a magma, and on the formation of secondary phases. Although the volatile content and temperature of intrusive basaltic magma at Yucca Mountain are different from those considered in the tests, the test results are used to demonstrate the possibility of reaction of metals at the metal-magma contacts. Some pertinent results of the tests outlined by Westrich 1990 include formation of $\mathrm{Fe}, \mathrm{Cr}$, and $\mathrm{Mn}$ oxides (e.g., magnetite- $\mathrm{Fe}_{3} \mathrm{O}_{4}$ ), silicates (e.g., fayalite- $\mathrm{Fe}_{2} \mathrm{SiO}_{4}$ ), and aluminum oxides (e.g., hercynite$\mathrm{FeAl}_{2} \mathrm{O}_{4}$ ) and mobilization of sulfur from magma and steels. 
The tests were conducted for periods ranging from several minutes to 22 days under conditions similar to the environment of a shallow rhyolitic magma $\left(850^{\circ} \mathrm{C}\right.$ and $\left.100 \mathrm{MPa}\right)$. The preliminary results for high carbon steel, under vapor saturated conditions, indicated the initial growth of large euhedral crystals of fayalite $\left(\mathrm{Fe}_{2} \mathrm{SiO}_{4}\right)$ outward from the magma-metal interfaces followed by growth of two spinel phases and initial phases of hercynite $\left(\mathrm{FeAl}_{2} \mathrm{O}_{4}\right)$ and magnetite $\left(\mathrm{Fe}_{3} \mathrm{O}_{4}\right)$. The results of the runs of longer duration showed continued growth of magnetite. The tests have also indicated that high carbon steel showed a zone of sulfidation beneath the zone of Fe oxides.

For the reaction of seepage water with the cooled basalt body, EQ6 indicates that the $\mathrm{pH}$ of the water is between 7.6 and 9.9. This is highly dependent on the $\mathrm{pCO}_{2}$ of the system. Higher $\mathrm{pCO}_{2}$ values show $\mathrm{pH}$ values between 7.6 and 8.6. Values between 9.0 and 9.6 are obtained with a $\log$ $\mathrm{pCO}_{2}$ of -3.5 and $\mathrm{pH}$ values between 9.4 to 9.9 can be obtained with a $\log \mathrm{pCO} 2$ of -4 . The $\mathrm{pH}$ values correspond to those obtained from groundwater taken from different basalt units within the Columbia Plateau, Washington. Hearn et al., 1985 indicate $\mathrm{pH}$ values between 6.7 and 9.3 and DOE 1982 indicates $\mathrm{pH}$ values between 7.6 and 10.1 with a mean of 8.1 for these basalt units. More specifically, Gislason and Eugster (1987) carried out laboratory studies on the reaction of meteoric waters with basalt. They show that at higher $\mathrm{pCO}_{2}$ values, the $\mathrm{pH}$ of the system tends to be near neutral (between 7 and 8) while those where $\mathrm{pCO}_{2}$ was limited had much higher $\mathrm{pH}$ waters (between 9 and 10). At higher $\mathrm{pCO}_{2}$ values, the buffering capacity of aqueous $\mathrm{CO}_{2}$ dominates. However, when $\mathrm{CO}_{2}$ is diminished, the buffering capacity is controlled by aqueous silica and carbon species, allowing the $\mathrm{pH}$ to rise between 9 and 10 (Gislason and Eugster (1987).

Minimum ionic strength values calculated with EQ6 are between 9.14E-03 and 1.97E-02 moles $/ \mathrm{kg}$. The ionic strength indicated in DOE 1982 for one water is between a maximum of $1.8 \mathrm{E}-02$ to a minimum of $7.4 \mathrm{E}-03 \mathrm{moles} / \mathrm{kg}$. Ionic strength calculated from the reported ions in various waters range from about $6.0 \mathrm{E}-03$ to almost $3.0 \mathrm{E}-02 \mathrm{moles} / \mathrm{kg}$. These values also agree with the values obtained from ionic species in White et al. 1980 and Hem 1985. The minimum values for ionic strength are in good agreement with the values obtained from DOE 1982, White et al. 1980, and Hem 1986. The maximum values obtained by EQ6 cannot be validated by corroboration with natural analogues. Instead, the maximum values recommended for use in TSPA in Table 8-2 are validated in Section 7.2.

For the heat calculation, the results are corroborated by the results from the Dike/Drift Interactions (BSC 2003 [DIRS: 165923])]. The Dike/Drift model shows that the values for the thermal properties of the magma and tuff may vary from those of newer measurements, which might differ by up to 10 percent. Calculations based on varying these properties by 10 percent (with the exception of the initial magma temperature) shows that each property varied accounts for only $\sim 3$ percent of the change in calculated temperatures. With respect to the thermal effects on neighbor drifts $\left(\sim 81 \mathrm{~m}\right.$ distant), a slight thermal pulse $\left(\sim 1^{\circ} \mathrm{C}\right)$ might be felt after 60 years of cooling. After 500 years of cooling, the magma-filled drift and surrounding tuff has cooled to within $0.5^{\circ} \mathrm{C}$ of the initial temperature $\left(30^{\circ} \mathrm{C}\right)$. These results are consistent with this model and therefor validate it.

In summary, model validation shows that the model predictions have been corroborated, where necessary, with pertinent natural and industrial analogs, published journal articles/literature and 
experimental results and the criterion have been met. Therefore, the level of confidence required for this model has been obtained.

\subsection{CONSERVATISM}

\section{Has the model been validated by demonstrating that it is conservative?}

Given the complex nature of the hypothetical igneous intrusion event and associated processes, the prediction of impacts on waste packages and waste forms is difficult to quantify. The impact assessment, model simulations, and analyses are based on conservative assumptions and bounding parameter values, and augmented by corroborative natural and industrial analogs and experimental results. Consequently, confidence in the model and its results is increased. In this assessment, bounding conditions associated with basalt intrusion are considered. The drip shield, cladding, and waste packages in Zone 1 fail to provide protection for the waste forms after the intrusion (see Section 6.5.1). Bounding parameters including a high temperature of $1150^{\circ} \mathrm{C}$, viscosity of $2.678 \mathrm{log}$ poise units, density of $2663 \mathrm{~kg} / \mathrm{m}^{3}$, and rapid ascent flux $\left(1 \times 10^{6}\right.$ $\mathrm{kg} \mathrm{s}^{-1} \mathrm{~m}^{-1}$ or volumetric velocity of $2.15 \times 10^{3} \mathrm{~m}^{3} \mathrm{~s}^{-1}$ ) of magma.

For modeling the chemical interaction of seepage water with basalt, a conservative approach was taken. For example, since the nature and extent of fracturing of the solidifying basalt are unknown and there are no data on the permeability of the intruding basalt, the basalt in the intersected drifts was assumed to have permeability at least as great as the drift wall rock (see Section 5.1). This assumption is conservative because, it ensures that the cooled magma does not act as a barrier to the flow of seepage water from the rock above the drifts to the waste forms after reversion of the system to normal conditions. The degree to which the seepage water equilibrates during its movement through the basalt is unknown, although some degree of chemical interaction based equilibration is expected.

The ionic strength of water from different basalt units is discussed in Section 7.1. Calculated ionic strength was dependent on the available data on ionic species from basalt waters. EQ6 shows that as the $\mathrm{pH}$ increases, the ionic strength increases, the highest ionic strength values occurring at the highest $\mathrm{pH}$ (correlating with the lowest $\mathrm{CO}_{2}$ values). At higher $\mathrm{pH}$ values, many more carbonate and silica species will be present in solution. These ions are not reported in the references cited for validation in Section 7.1. It is therefore reasonable that at higher $\mathrm{pH}$ values (lower $\mathrm{CO}_{2}$ ), that the ionic strength is higher than that represented in Section 7.1. Therefore, this model recommends using the upper bound of waste colloid stability presented Waste Form and In-Drift Colloids-Associated Radionuclide Concentrations: Abstraction and Summary (BSC 2003 [DIRS: 166845], Table 17) in cases where the maximum ionic strength exceeds 0.05 moles $/ \mathrm{kg}$. Since this value $(0.05$ moles $/ \mathrm{kg})$ represents the upper bound at which waste colloids are stable, it is conservative in that it allows colloids to exist.

In summary, model validation shows that the model is conservative and this corroborative criterion has been met.

The model has met the criterion for a medium level of confidence per the technical work plan (BSC 2004 [DIRS:167796]), as discussed above in Sections 7.1 and 7.2. In addition to validation using the 3 criteria stated at the beginning of Section 7, an additional observation is 
discussed for further verification and corroboration. This supporting criteria is presented in Section 7.3.

\subsection{SUPPORTING CRITERIA}

Has the model considered a credible scientific approach, principles and concepts?

This process model has considered probable igneous intrusion and consequential processes during intrusion, cooling of intrusion and post-cooling of intrusion. Based on these sequential processes, two sets of conceptual models, with conservative assumptions, were considered: a) Base-Case Conceptual Model and b) Alternative Conceptual Models.

The base-case conceptual model was based on the igneous intrusion event and resulting processes stated in Section 6.3.

In contrast to the base-case model scenario, several alternative conceptual models were developed to cover other possibilities that may be relevant for igneous intrusive event impacts on the waste packages and waste forms. These include the scenarios presented in Section 6.4 of this report.

Due to the large uncertainty of the parameters used in the alternative conceptual models, the models were only described briefly in Section 6.4 .

In summary, model validation shows that the model considers credible scientific approaches, principles, and concepts and the corroborative criterion has been met.

\section{CONCLUSIONS}

The characteristics of a basaltic hypothetical igneous intrusion are given in Characterize Eruptive Processes at Yucca Mountain, Nevada (BSC 2003 [DIRS:166407]).

In this model, damage to waste package and waste forms from an igneous intrusion is considered in terms of two damage zones. Zone 1, comprising the entirety of the drifts intersected by the intrusion, and Zone 2, comprising all other parts of the repository. Impacts of the intrusion to waste packages and waste forms as well as analyses of the affects of heat and gas flow from Zone 1 to Zone 2 were conducted to assess the impacts to waste packages and waste forms in Zone 2. Further analysis was conducted on the change in seepage water composition that may occur after the basalt cools and seepage water flow is re-established, allowing it to react with the intruded basalt in Zone 1 .

\subsection{MODEL OUTPUT}

The information in Section 6.5.1.1 supports the use of the TSPA assumption that waste packages in Zone 1 emplacement drifts no longer provide protection for the waste forms. The waste packages and other drift materials would be enclosed by the magma. The full detail of effects of magma intrusion on waste packages and cladding are not known. However, these results are 
conservative because, in this approach, no credit is taken for any residual waste-shielding effects of remaining waste package or cladding material.

The impacts of magmatic heat conduction on the waste packages in Zone 2 emplacement drifts was modeled. Temperatures were modeled by numerical simulations of non-steady state heat conduction with radial flow.

The simulation modeling of heat conduction away from the intruded drifts demonstrates that the initial $1150^{\circ} \mathrm{C}$ temperature reduces to about $30^{\circ} \mathrm{C}$ at the center of the drift in about 30 years, and the maximum temperature rise expected in the Zone 2 emplacement drifts is less than $1^{\circ} \mathrm{C}$. The drift-rock in Zone 2 provides an effective thermal insulation barrier to the impacts of high temperature of the intruded magma, and there would not be any impact of igneous heat on the waste packages in Zone 2 emplacement drifts.

Thermal calculations show that the effects of intrusions on Zone 2 would be negligible. BSC 2003 [DIRS: 165923] shows that the gases that compose the majority of the exsolved gases $\left(\mathrm{H}_{2} \mathrm{O}, \mathrm{CO}_{2}\right.$, and $\left.\mathrm{SO}_{2}\right)$ of the gas front are significantly retarded so that they have no effect on Zone 2 emplacement drifts. Therefore, it is assumed (Section 5.4) that other corrosive gases such as $\mathrm{HF}$ and $\mathrm{HCl}$, which are present in minor quantities in the gas front, are also retarded. Therefore, TSPA-LA treatment of the barrier capability of waste packages in Zone 2 emplacement drifts should be the same as that under the nominal scenario.

As the waste packages are expected to be within the magma body, then the temperature of waste forms can be considered the same as the temperature of the cooling magma. These values are presented in the lookup-table (Table 8-1) for magma cooling temperatures (for $T_{r=0 m}$ ). The temperature of the invert can also be taken from Table 8-1 for temperatures of the magma body at a radius of 3 meters from the center of the magma filled drift $\left(T_{r=3 m}\right)$. Because of the rapid change in temperature early in time, the temperatures for times between zero and the length of the TSPA time step (in years) should be sampled uniformly. The temperatures for times greater than the TSPA time step but less than 100 years should be taken directly from Table $8-1$. The uncertainty in the temperature, as indicated in Section 6.6.1, is $\pm 3^{\circ} \mathrm{C}$ sampled as a uniform distribution. These values are warehoused in DTN: MO0402SPAHWCIG.002.

Processes accompanying magma intrusion and cooling may influence environmental conditions affecting radionuclide release from Zone 1 . These processes include physical damage and disruption of the drift walls, formation of a contact metamorphic aureole and the filling of the drift with solid basalt. Based on consideration of the properties of natural analogs of contact metamorphic aureoles and of the development of fractures in cooling basalt, it was assumed (Section 5.1) that seepage rate through the basalt-filled Zone 1 drifts would be the same as if no intrusion had occurred. Abstraction of Drift Seepage (BSC 2004 [DIRS:167970]) indicates that it is reasonable to use non-degraded drift water inflow as the estimated water flow after an igneous event. Additional conservatism can be added by using the seepage for a collapsed drift. For the aqueous chemistry of the in-drift environment, it is appropriate to use the non-degraded configuration.

The chemistry of the incoming seepage may be affected by basalt-water reactions within the drift. The effects of these reactions on a typical crown seepage water have been modeled in 
Section 6.5.3 and the results of the abstraction for feed to TSPA are outlined in Section 6.7.2 and are reiterated below.

The values presented in Table 8-2 do not represent an absolute range, but the range of values for the parameters expressed in Section 6.6.2.1. If those ranges were slightly modified, it is expected that the $\mathrm{pH}$ and ionic strength values may change slightly. Therefore, it is recommended that TSPA sample uniformly between the minimum and maximum values in Table 8-2. These values are warehoused in DTN: MO0402SPAHWCIG.002.

The model recommends using the upper bound of waste colloid stability presented in Waste Form and In-Drift Colloids-Associated Radionuclide Concentrations: Abstraction and Summary (BSC 2003 [DIRS: 166845], Table 17) in cases where the maximum ionic strength exceeds 0.05 moles $/ \mathrm{kg}$. Since this value $(0.05 \mathrm{moles} / \mathrm{kg})$ represents the upper bound at which waste colloids are stable, it is conservative in that it allows colloids to remain stable. Setting the maximum ionic strength to 0.05 moles $/ \mathrm{kg}$ has no effect on how TSPA will use this information in conjunction with Dissolved Concentration Limits of Radioactive Elements (BSC 2003 [DIRS:163152]) since the model indicates that ionic strength must be above $1 \mathrm{~mole} / \mathrm{kg}$ before this factor begins to affect dissolution of waste forms.

Fluoride content of the water in contact with basalt is listed as one of the outputs of this model in Technical Work Plan for Waste Form Degradation Modeling, Testing, and Analyses in Support of LA (BSC 2004 [DIRS:167796]). However, this parameter is not necessary to determine fuel dissolution rates per Dissolved Concentration Limits of Radioactive Elements (BSC 2003 [DIRS:163152] where it is presented as an uncertainty. Additionally, several EQ6 cases (see Attachment III, Disc 1 and 2, for output files) show that concentration can decrease from precipitation of mineral phases that contain fluorine $(\mathrm{F})$. However, this is highly dependent on the phosphorus content of the fluid. Many EQ6 simulations of basalt/water interactions show no change in fluoride content. Therefore, no abstraction of this parameter was completed. Should fluoride content be of future interest, the fluoride content used should be the initial fluoride content of the water entering the drift.

Water seeping through the cooled, fractured basalt would contact the spent fuel and waste and begin to dissolve them. The solubility of the waste forms would depend on the chemistry of the water as described in Dissolved Concentration Limits of Radioactive Elements (BSC 2003 [DIRS:163152]). This report gives tables of the solubilities of elements with safety-relevant radionuclides over a range of values of $\mathrm{pH}$ and $\mathrm{fCO}_{2}$. Variations in other water chemistry parameters including temperature and fluoride concentrations are included in the uncertainties associated with the solubilities.

As the seepage water percolates through the basalt and comes into contact with the waste forms, it may form secondary mineral phases (commonly called rind) on the waste forms making the radionuclides available for release. Instructions for the use of these rinds in the TSPA-LA can be found in Section 6.7.2. These instructions dictate that the TSPA-LA should refer to the individual model reports cited here: Clad Degradation - Summary and Abstraction for LA (BSC 2003 [DIRS: 162153]) and Defense HLW Glass Degradation Model (BSC 2004 [DIRS:167619]). See Section 6.7.2 for more information. 
Igneous Intrusion Impacts on Waste Packages and Waste Forms

Table 8-1. Look-Up Tables for Temperature of Waste Forms

\begin{tabular}{|c|c|c|c|c|c|c|c|c|c|c|}
\hline \multirow{2}{*}{\begin{tabular}{|l|} 
Time $(t)$ \\
Years* \\
\end{tabular}} & \multicolumn{2}{|c|}{$\begin{array}{c}\text { For an Intrusion } \\
\text { into a Repository } \\
\text { at } 25^{\circ} \mathrm{C}\end{array}$} & \multicolumn{2}{|c|}{$\begin{array}{c}\text { For an Intrusion } \\
\text { into a Repository } \\
\text { at } 50^{\circ} \mathrm{C}\end{array}$} & \multicolumn{2}{|c|}{$\begin{array}{c}\begin{array}{c}\text { For an Intrusion } \\
\text { into a Repository } \\
\text { at } 100^{\circ} \mathrm{C}\end{array} \\
\end{array}$} & \multicolumn{2}{|c|}{$\begin{array}{c}\text { For an Intrusion } \\
\text { into a Repository } \\
\text { at } 150^{\circ} \mathrm{C}\end{array}$} & \multicolumn{2}{|c|}{$\begin{array}{c}\text { For an Intrusion } \\
\text { into a Repository } \\
\text { at } 200^{\circ} \mathrm{C}\end{array}$} \\
\hline & $T_{r=0 m}$ & $T_{r=3 m}$ & $T_{r=0 m}$ & $T_{r=3 m}$ & $T_{r=0 m}$ & $\mathbf{T}_{\mathrm{r}=3 \mathrm{~m}}$ & $\mathbf{T}_{\mathrm{r}=0 \mathrm{~m}}$ & $T_{r=3 m}$ & $T_{r=0 m}$ & $T_{r=3 m}$ \\
\hline 0 & 1150 & 1150 & 1150 & 1150 & 1150 & 1150 & 1150 & 1150 & 1150 & 1150 \\
\hline 0.1 & 977 & 592 & 1006 & 620 & 1012 & 644 & 1019 & 668 & 1026 & 692 \\
\hline 0.2 & 702 & 462 & 749 & 494 & 768 & 524 & 786 & 553 & 804 & 583 \\
\hline 0.3 & 530 & 382 & 577 & 416 & 603 & 449 & 629 & 483 & 655 & 516 \\
\hline 0.4 & 422 & 326 & 467 & 360 & 498 & 396 & 529 & 432 & 560 & 468 \\
\hline 0.5 & 351 & 284 & 394 & 318 & 428 & 356 & 462 & 394 & 497 & 431 \\
\hline 0.6 & 301 & 252 & 341 & 286 & 378 & 325 & 415 & 364 & 452 & 403 \\
\hline 0.7 & 264 & 226 & 303 & 260 & 341 & 300 & 380 & 341 & 418 & 381 \\
\hline 0.8 & 236 & 206 & 273 & 239 & 313 & 281 & 353 & 322 & 392 & 363 \\
\hline 0.9 & 213 & 189 & 249 & 222 & 290 & 264 & 331 & 306 & 372 & 349 \\
\hline 1 & 195 & 175 & 230 & 208 & 272 & 251 & 314 & 293 & 356 & 336 \\
\hline 2 & 111 & 106 & 142 & 136 & 187 & 182 & 233 & 228 & 279 & 274 \\
\hline 3 & 82.8 & 80.4 & 111 & 109 & 158 & 156 & 206 & 203 & 253 & 251 \\
\hline 4 & 68.4 & 67.0 & 96.0 & 94.5 & 144 & 142 & 192 & 190 & 240 & 238 \\
\hline 5 & 59.7 & 58.9 & 86.8 & 85.8 & 135 & 134 & 183 & 183 & 232 & 231 \\
\hline 6 & 54.0 & 53.4 & 80.7 & 80.0 & 129 & 129 & 178 & 177 & 227 & 226 \\
\hline 7 & 49.8 & 49.4 & 76.3 & 75.8 & 125 & 125 & 174 & 173 & 223 & 222 \\
\hline 8 & 46.7 & 46.4 & 73.0 & 72.6 & 122 & 122 & 171 & 171 & 220 & 220 \\
\hline 9 & 44.3 & 44.0 & 70.5 & 70.2 & 120 & 119 & 169 & 168 & 218 & 217 \\
\hline 10 & 42.4 & 42.2 & 68.4 & 68.2 & 118 & 117 & 167 & 167 & 216 & 216 \\
\hline 20 & 33.7 & 33.6 & 59.2 & 59.2 & 109 & 109 & 158 & 158 & 208 & 208 \\
\hline 30 & 30.8 & 30.8 & 56.1 & 56.1 & 106 & 106 & 156 & 156 & 205 & 205 \\
\hline 30 & 29.3 & 29.3 & 54.6 & 54.6 & 104 & 104 & 154 & 154 & 204 & 204 \\
\hline 50 & 28.5 & 28.5 & 53.7 & 53.7 & 104 & 104 & 153 & 153 & 203 & 203 \\
\hline 60 & 27.9 & 27.9 & 53.1 & 53.1 & 103 & 103 & 153 & 153 & 203 & 203 \\
\hline 70 & 27.5 & 27.5 & 52.6 & 52.6 & 103 & 103 & 152 & 152 & 202 & 202 \\
\hline 80 & 27.2 & 27.2 & 52.3 & 52.3 & 102 & 102 & 152 & 152 & 202 & 202 \\
\hline 90 & 26.9 & 26.9 & 52.0 & 52.0 & 102 & 102 & 152 & 152 & 202 & 202 \\
\hline 100 & 26.7 & 26.7 & 51.8 & 51.8 & 102 & 102 & 152 & 152 & 202 & 202 \\
\hline
\end{tabular}

Source: Calculated in various spreadsheets in Attachment III (Disc 1, "Heat" folder)

NOTES: $T_{r=0}$ is the centerline temperature and $T_{r=3}$ is the temperature at the edge of the dike.

*Time ( $t$ ) represents time from the igneous intrusive event.

Values archived in output DTN: MO0402SPAHWCIG.002 
Igneous Intrusion Impacts on Waste Packages and Waste Forms

Table 8-2. Look-Up Table of Temporal Maximum and Minimum Values for $\mathrm{pH}$ and lonic Strength for Use in TSPA-LA

\begin{tabular}{|c|c|c|c|c|}
\hline \multicolumn{5}{|c|}{$\log \mathrm{fCO}_{2}=-2$ bar } \\
\hline & \multicolumn{2}{|c|}{$\mathrm{pH}$} & \multicolumn{2}{|c|}{ lonic Strength (moles/kg) } \\
\hline Time Period* & Maximum & Minimum & Maximum & Minimum \\
\hline$x \leq 25$ years & 7.9 & 7.6 & 1.87E-02 & $9.64 E-03$ \\
\hline $25>x \leq 250$ years & 8.1 & 7.8 & $3.59 \mathrm{E}-02$ & $1.23 \mathrm{E}-02$ \\
\hline $250>x \leq 2500$ years & 8.1 & 7.8 & 4.00E-02 & 1.22E-02 \\
\hline $2500>x \leq 20000$ years & 8.1 & 7.7 & $3.58 \mathrm{E}-02$ & 1.15E-02 \\
\hline \multicolumn{5}{|c|}{$\log \mathrm{fCO}_{2}=-2.5 \mathrm{bar}$} \\
\hline & \multicolumn{2}{|c|}{$\mathrm{pH}$} & \multicolumn{2}{|c|}{ lonic Strength (moles/kg) } \\
\hline Time Period* & Maximum & Minimum & Maximum & Minimum \\
\hline$x \leq 25$ years & 8.4 & 8.1 & $2.09 \mathrm{E}-02$ & $9.23 \mathrm{E}-03$ \\
\hline $25>x \leq 250$ years & 8.6 & 8.3 & 4.33E-02 & 1.31E-02 \\
\hline $250>x \leq 2500$ years & 8.6 & 8.3 & $5.00 \mathrm{E}-02$ & $1.29 \mathrm{E}-02$ \\
\hline $2500>x \leq 20000$ years & 8.6 & 8.2 & 4.22E-02 & 1.18E-02 \\
\hline \multicolumn{5}{|c|}{$\log \mathrm{fCO}_{2}=-3 \mathrm{bar}$} \\
\hline & \multicolumn{2}{|c|}{$\mathrm{pH}$} & \multicolumn{2}{|c|}{ lonic Strength (moles/kg) } \\
\hline Time Period* & Maximum & Minimum & Maximum & Minimum \\
\hline$x \leq 25$ years & 8.9 & 8.6 & 2.43E-02 & $9.14 \mathrm{E}-03$ \\
\hline $25>x \leq 250$ years & 9.0 & 8.8 & $5.00 \mathrm{E}-02$ & $1.40 \mathrm{E}-02$ \\
\hline $250>x \leq 2500$ years & 9.1 & 8.8 & $5.00 \mathrm{E}-02$ & 1.37E-02 \\
\hline $2500>x \leq 20000$ years & 9.1 & 8.7 & 5.00 E-02 & 1.19E-02 \\
\hline \multicolumn{5}{|c|}{$\log \mathrm{fCO}_{2}=-3.5 \mathrm{bar}$} \\
\hline & \multicolumn{2}{|c|}{$\mathrm{pH}$} & \multicolumn{2}{|c|}{ lonic Strength (moles/kg) } \\
\hline Time Period ${ }^{\star}$ & Maximum & Minimum & Maximum & Minimum \\
\hline$x \leq 25$ years & 9.4 & 9.0 & $3.00 \mathrm{E}-02$ & 9.44E-03 \\
\hline $25>x \leq 250$ years & 9.5 & 9.2 & $5.00 \mathrm{E}-02$ & 1.67E-02 \\
\hline $250>x \leq 2500$ years & 9.6 & 9.2 & $5.00 \mathrm{E}-02$ & 1.62E-02 \\
\hline $2500>x \leq 20000$ years & 9.5 & 9.1 & $5.00 \mathrm{E}-02$ & $1.30 \mathrm{E}-02$ \\
\hline \multicolumn{5}{|c|}{$\log \mathrm{fCO}_{2}=-4$ bar } \\
\hline & \multicolumn{2}{|c|}{$\mathrm{pH}$} & \multicolumn{2}{|c|}{ Ionic Strength (moles/kg) } \\
\hline Time Period* & Maximum & Minimum & Maximum & Minimum \\
\hline$x \leq 25$ years & 9.7 & 9.4 & $3.42 \mathrm{E}-02$ & $1.02 \mathrm{E}-02$ \\
\hline $25>x \leq 250$ years & 9.9 & 9.6 & $5.00 \mathrm{E}-02$ & 1.97E-02 \\
\hline $250>x \leq 2500$ years & 9.9 & 9.6 & $5.00 \mathrm{E}-02$ & $1.89 \mathrm{E}-02$ \\
\hline $2500>x \leq 20000$ years & 9.9 & 9.6 & $5.00 \mathrm{E}-02$ & 1.43E-02 \\
\hline
\end{tabular}

NOTE: * Time period represents time after re-establishment of seepage flow.

Values archived in output DTN: MO0402SPAHWCIG.002

In some instances, TSPA may need $\mathrm{pH}$ and ionic strength values for a range of parameters that are outside the range of validity of this model. These parameters include flux and $\mathrm{Log} \mathrm{fCO}_{2}$. In the case of flux, it was observed in EQ6 calculations (See "rate comparison.xls" in Attachment 
III) that after a flux rate of $50 \mathrm{~mm} /$ year was obtained, the output water composition was within $0.8 \mathrm{pH}$ units and $1.15 \mathrm{E}-03 \mathrm{moles} / \mathrm{kg}$ of the original $\mathrm{pH}$ and ionic strength values (i.e. Time $=0$ values). For this reason, a flux rate of $50 \mathrm{~mm} /$ year is chosen for TSPA as the point were the $\mathrm{pH}$ and ionic strength of the water (equilibrated with atmospheric gas levels) flowing into the basalt block equals the $\mathrm{pH}$ and the ionic strength of the water leaving the basalt block. For flux rates less than $50 \mathrm{~mm} /$ year, the values from Table 8-2 can be used. As shown in Dissolved Concentration Limits of Radioactive Elements (BSC 2003 [DIRS:163152]), the two most important parameters affecting the solubility of radioelements include $\mathrm{pH}$ and $\mathrm{fCO}_{2}$. Since $\mathrm{pH}$ decreases with increasing flux rate, using the values for flux between 0.4 and $11.7 \mathrm{~mm} /$ year for any cases where the flux is below $50 \mathrm{~mm} /$ year is conservative since the radionuclides will be more soluble at the higher $\mathrm{pH}$ values shown in Table 8-2.

Convergence difficulties arise in EQ6 calculations carried out at high $\mathrm{pH}$ and low $\mathrm{CO}_{2}$ levels. For this reason, the model includes $\log \mathrm{fCO}_{2}$ values only from -2 to -4 bar. For TSPA calculations where the $\log \mathrm{fCO}_{2}$ is between -4 and -5 bar, it is recommended that the values in Table 8-2 for $\log \mathrm{fCO}_{2}$ of -4 bar be used. Natural analogues (Hearn et al., 1985 and DOE 1982) show that the $\mathrm{pH}$ of water in contact with basalt (depending on the $\mathrm{CO}_{2}$ levels) can be between 6.7 and 10.1 with the majority of data showing $\mathrm{pH}$ values of 8.5 to almost 10 . Ionic strength is shown between $1.8 \mathrm{E}-02$ to a minimum of $7.4 \mathrm{E}-03$ moles $/ \mathrm{kg}$. Therefore the $\mathrm{pH}$ and ionic strength for $\log \mathrm{fCO}_{2}$ between -4 and -5 bar should, realistically, not be much greater than those presented in Table 8-2. For the upper end of the $\mathrm{CO}_{2}$ range used by TSPA ( -1.7 bar), TSPA calculations should use the $\log \mathrm{fCO}_{2}$ values at -2 bar.

\subsection{OUTPUT UNCERTAINTY}

\subsubsection{Heat Flow Calculation}

Uncertainties from various sources have been addressed in this model report (Attachment $I$ and Section 6.6.1). These include thermal conductivity, grain density, specific heat capacity, matrix porosity, saturation, lithophysal porosity, and initial temperature. Of these, it was shown that only the initial temperature had any effect. The uncertainty in the temperature, as indicated in Section 6.6.1, is $\pm 3^{\circ} \mathrm{C}$ for the temperature output.

\subsubsection{EQ6 Calculations}

Uncertainties from various sources have been addressed in this model report (Section 6.6.2). These include pore fraction, reactive surface area of materials, flow rate of water through the basalt, saturation, composition of oxides that make up the basalt, $\mathrm{CO}_{2}$ and $\mathrm{O}_{2}$ fugacity, and type of water flowing through the basalt. The uncertainty in the output for reaction of basalt and seepage waters is summarized in Table 6-11.

\subsection{RESTRICTIONS}

As discussed in Section 6.6.2, the $\mathrm{pH}$ and ionic strength values developed in this model report for reaction of seepage water and basalt are valid for certain parameter ranges. These are provided in Table 8-3. 
Igneous Intrusion Impacts on Waste Packages and Waste Forms

Table 8.3. Valid Range of pH and lonic Strength Reported in This Model Report

\begin{tabular}{|c|c|}
\hline Parameter & Value or Range of Values Used \\
\hline Pore fraction & 0.13 through 0.17 \\
\hline Flow rate (flux) & $0.4 \mathrm{~mm} /$ year through $11.7 \mathrm{~mm} / \mathrm{year}$ \\
\hline Surface area & All surfaces are available and $10 \%$ of all surfaces \\
available \\
\hline Saturation & 0.1 through 1.0 \\
\hline Log $\mathrm{f}_{\mathrm{CO} 2}$ & -2 through -4 bar \\
\hline Log $\mathrm{f}_{\mathrm{O} 2}$ & -0.7 bar \\
\hline
\end{tabular}

The end of Section 8.1 describes how this model is to be used in TSPA should values of flow rate and $\mathrm{fCO}_{2}$ values are outside the range presented in Table 8-3.

\subsection{YUCCA MOUNTAIN REVIEW PLAN ACCEPTANCE CRITERIA}

The purpose of the Waste Package and Waste Form Impacts model (TSPA-LA submodel) is to provide an analytical framework to evaluate the potential effects of a hypothetical, future basaltic igneous intrusion that intersects the repository. Of specific interest are potentially deleterious dynamic, thermal, hydrologic, and chemical impacts that could result from the intrusion of a basaltic dike into one or more repository drifts. The TSPA-LA approach for implementing the models for waste package and waste form response during and following an igneous intrusion is based on the identification of two damage zones. Zone 1 includes the emplacement drift intruded by the basalt dike. Zone 2 includes the emplacement drifts adjacent to Zone 1 but not directly intersected by a dike. The model describes:

- Impacts of magma intrusion on components of engineered barrier system (drip shields, cladding and waste packages) in Zone 1 , and the fate of waste forms

- Impacts of intrusion-related thermal conduction/convection and migrating magmatic gases on the drip shields, cladding and waste packages in Zone 2 emplacement drifts, adjacent to the intruded drift

- Impacts of intrusion on in-drift thermal and geochemical environments, including seepage hydrochemistry, which may affect the release, and fate and transport of radionuclides.

The following description identifies information in this report that addresses acceptance criteria and/or review methods from Yucca Mountain Review Plan, Final Report (NRC 2003, Section 2.2.1.3.2.3) that are related to the integrated sub-issue of mechanical disruption of engineered barriers.

\section{Acceptance Criterion 1: System description and model integration are adequate}

The objectives for modeling magma-waste package/waste form interactions are described in Section 6.1 of the model report. The main objective of this model is to assess the potential impacts of an igneous intrusion on waste package and waste form performance, including: 
- Mechanical and thermal impacts of basalt magma intrusion on the waste packages and waste forms of the intersected emplacement drifts of zone

- Temperature and pressure trends of basaltic magma intrusion intersecting the Zone 1 and their potential effects on waste packages and waste forms in Zone 2 emplacement drifts

- Geochemical conditions, due to basaltic magma intrusion intersecting the Zone 1 drift(s), and their potential effects on waste packages and waste forms in Zones 1 and 2

- Deleterious volatile gases from the intruded basalt magma and their potential effects on waste packages of Zone 2 emplacement drifts

- Post-intrusive physical-chemical environment and seepage water alteration by reaction with intruded basalt.

(1) Total system performance assessment adequately incorporates important design features, physical phenomena, and couplings, and uses consistent and appropriate assumptions throughout the mechanical disruption of engineered barrier abstraction process.

The report documents the base-case conceptual model (Section 6.3) for magma-waste package/waste form interactions and alternative conceptual models (Section 6.4). Results from exercise of the base-case model are described in Section 6.5. Impacts on waste packages in Zone 1 are described in Section 6.5.1.1 and impacts on waste forms in Zone 1 are discussed in Section 6.5.1.2. The numerical simulations of heat flow around Zone 1 are described in Section 6.5.2.1. Results of the heat flow modeling are described in Section 6.5.2.1.1. Gas flow is described in Section 6.5.2.2. The results indicate the waste packages in Zone 2 would not be affected by heat conducted from magma in drifts in Zone 1 .

Based on the description in Sections 6.5.2.1 and 6.5.2.2, there is little basis or need to define damage Zone 2 (as described in TSPA-SR) peripheral to Zone 1 for TSPA-LA.

Section 6.5.3 describes EQ6 modeling of post-intrusion geochemical interactions of seepage water with basalt (Zone 1) after cooling of the basalt.

(2) The description of geological and engineering aspects of design features, physical phenomena, and couplings that may affect mechanical disruption of engineered barriers is adequate. For example, the description may include materials used in the construction of engineered barrier components, environmental effects (e.g., temperature, water chemistry, humidity, radiation, etc.) on these materials, and mechanical failure processes and concomitant failure criteria used to assess the performance capabilities of these materials. Conditions and assumptions in the abstraction of mechanical disruption of engineered barriers are readily identified and consistent with the body of data presented in the description.

Properties of the basalt are described in Section 4.1.2 and presented in Tables 4-3 through 4-6. The material properties of the basalt are used to model changes in water that contacts the basalt. 
Numerical simulation of heat flow around Zone 1 emplacement drifts is described in Section 6.5.2, and the simulation results indicate that the increase in temperatures in the surrounding drifts (in Zone 2$)$ is small $\left(<10^{\circ} \mathrm{C}\right)$. This result is interpreted to show that the rocks provide an effective thermal barrier (insulation) and would limit the effects from a high temperature intrusion of basaltic magma. Hence, the results indicate that waste packages in Zone 2 would not be affected by heat transfer from Zone 1 drifts.

(3) The abstraction of mechanical disruption of engineered barriers uses assumptions, technical bases, data, and models that are appropriate and consistent with other related U.S. Department of Energy abstractions. For example, assumptions used for mechanical disruption of engineered barriers are consistent with the abstraction of degradation of engineered barriers (Section 2.2.1.3.1 of Yucca Mountain Review Plan, Final Report [NRC 2003]). The descriptions and technical bases provide transparent and traceable support for the abstraction of mechanical disruption of engineered barriers.

This model report documents the development of the conceptual models, model enumeration, and simulations of interactions between basaltic magma, and waste packages and waste forms in emplacement drifts intersected by a dike and adjacent to the intersected drifts. The material properties of the basalt (from Section 4.1.2) are used to model changes in water that contacts basalt.

Inputs for heat flow calculations and model simulations are described in Section 4.1.1. Inputs for EQ6 simulation of water/basalt reaction hydrochemistry are described in Section 4.1.2.

Documentation of assumptions specific to the intrusive event and its effects on waste packages and waste forms is provided in Section 5.

(4) Boundary and initial conditions used in the total system performance assessment abstraction of mechanical disruption of engineered barriers are propagated throughout the abstraction approaches.

Basalt properties are described in Section 4.1.2 and presented in Tables 4-3 through 4-6. The material properties of the basalt are used to model changes in water that contacts the basalt. Inputs for heat flow calculations and model simulations are described in Section 4.1.1. Inputs for EQ6 simulation of water/basalt reaction hydrochemistry are described in Section 4.1.2.

Documentation of assumptions specific to the intrusive event and its effects on waste packages and waste forms and EQ3/6 simulations is provided in Section 5.

(5) Sufficient data and technical bases to assess the degree to which features, events, and processes have been included in this abstraction are provided.

FEPs that are specifically addressed by information in this model report are identified in Table 6-1. One FEP, 1.2.04.04.0A, Igneous intrusion interacts with EBS components, is addressed in this model report. The table identifies sections of the report in which disposition of the FEP is described and includes a summary of the TSPA-LA disposition. 
Basically, the output of the model provides descriptions of physical and chemical conditions for application in the TSPA-LA in-drift sub-models.

(6) The conclusion, with respect to the impact of transient criticality on the integrity of the engineered barriers, is defensible.

This model report does not address the impact of transient criticality on the integrity of the engineered barriers.

(7) Guidance in NUREG-1297 (Altman et al. 1988a) and NUREG-1298 (Altman et al. 1988b), or other acceptable approaches, is followed.

NUREG-1297 (Altman et al. 1988a) describes the generic technical position with respect to the use of peer reviews on high-level waste repository programs. Peer review was not used in the development of the report. NUREG-1298 (Altman et al. 1988b), describes the generic technical position with respect to qualification of existing data. This report does not document the results of qualification of existing data.

\section{Acceptance Criterion 2: Data are sufficient for model justification}

(1) Geological and engineering values, used in the license application to evaluate mechanical disruption of engineered barriers, are adequately justified. Adequate descriptions of how the data were used and appropriately synthesized into the parameters are provided.

The basalt properties are described in Section 4.1.2 and presented in Tables 4-3 through 4-6. The material properties of basalt are used to model changes in water that contacts basalt. Inputs for heat flow calculations and model simulations are described in Section 4.1.1. Inputs for EQ6 simulation of water/basalt reaction hydrochemistry are described in Section 4.1.2.

Documentation of assumptions specific to the intrusive event and its effects on waste packages and waste forms as well as EQ3/6 simulations is provided in Section 5.

(2) Sufficient data have been collected on the geology of the natural system, engineering materials, and initial manufacturing defects to establish initial and boundary conditions for the total system performance abstraction of mechanical disruption of engineered barriers.

The basalt properties are described in Section 4.1.2 and presented in Tables 4-3 through 4-6. The material properties of basalt are used to model changes in water that contacts basalt. Inputs for heat flow calculations and model simulations are described in Section 4.1.1. Inputs for EQ6 simulation of water/basalt reaction hydrochemistry are described in Section 4.1.2.

(3) Data on geology of the natural system, engineering materials, and initial manufacturing defects, used in the total system performance assessment abstraction, are based on appropriate techniques. These techniques may include laboratory experiments, site-specific field measurements, natural analog research, and process-level modeling studies. As appropriate, sensitivity or uncertainty analyses used to support the U.S. Department of 
Energy total system performance assessment abstraction are adequate to determine the possible need for additional data.

The basalt properties are described in Section 4.1.2 and presented in Tables 4-3 through 4-6. The material properties of basalt are used to model changes in water that contacts basalt. Inputs for heat flow calculations and model simulations are described in Section 4.1.1. Inputs for EQ6 simulation of water/basalt reaction hydrochemistry are described in Section 4.1.2.

(4) Engineered barrier mechanical failure models for disruption events are adequate. For example, these models may consider effects of prolonged exposure to the expected emplacement drift environment, material test results not specifically designed or performed for the Yucca Mountain site, and engineered barrier component fabrication flaws.

The objectives of the modeling of igneous intrusion impacts on the waste package and waste form are described in Section 6.1. The base-case conceptual model and alternative conceptual models are described, respectively, in Sections 6.3 and 6.4. Identification of the software codes used in the analysis and their applicability to the modeling of magma-waste package and magma-waste form interactions are described in Section 3.1. Section 3.1 compares the specifics of the EQ3/6 and EQ6 codes. Simulation conditions for the base-case conceptual model are described in Section 4.1.1, 4.1.2, 6.5.1, 6.5.2, and 6.5.3, and results of numerical simulations of heat flow around Zone 1 emplacement drifts filled with basalt magma are described in Section 6.5.2.1. Gas flow around Zone 1 emplacement drifts filled with basalt magma is described in Section 6.5.2.2. Results of post-intrusion geochemical interactions of seepage water with basalt are described in Section 6.5.3.

\section{Acceptance Criterion 3: Data uncertainty is characterized and propagated through the model abstraction}

Data and parameters used for the analysis of magma-waste package and magma-waste form interactions is described in Section 4.1.

(1) Models use parameter values, assumed ranges, probability distributions, and bounding assumptions that are technically defensible, reasonably account for uncertainties, and variabilities, and do not result in an under-representation of risk.

Inputs for heat flow calculations and model simulations are described in Section 4.1.1. Inputs for EQ6 simulation of water/basalt reaction hydrochemistry are described in Section 4.1.2. The uncertainty in inputs as they are propagated in the calculation in the model is described in Section 6.6.

The representation of risk is a TSPA-LA responsibility. This report describes no results that could be used to evaluate the representation of risk from magma-drift and magma-waste package interactions.

(2) Process-level models used to represent mechanically disruptive events within the emplacement drifts at the proposed Yucca Mountain repository are adequate. Parameter values are adequately constrained by Yucca Mountain site data, such that the estimates of 
mechanically disruptive events on engineered barrier integrity are not underestimated. Parameters within conceptual models for mechanically disruptive events are consistent with the range of characteristics observed at Yucca Mountain.

The base-case conceptual model and alternative conceptual models are described, respectively, in Sections 6.3 and 6.4. Identification of the software codes used in the analysis and their applicability to the modeling of magma-waste package and magma-waste form interactions are described in Section 3.1. Section 3.1 compares the specifics of the EQ3/6 and EQ6 codes. Simulation conditions for the base-case conceptual model are described in Sections 4.1.1, 4.1.2, 6.5.1, 6.5.2, and 6.5.3, and results of numerical simulations of heat flow around Zone 1 emplacement drifts filled with basalt magma are described in Section 6.5.2.1. Flow of volatile components from a basaltic intrusion are described in Section 6.5.2.2, and results of post-intrusion geochemical interactions of seepage water with basalt are described in Section 6.5.3.

Assumptions needed to support the modeling of magma-waste package and magma-waste form interactions are described in Section 5.

Inputs for heat flow calculations and model simulations are described in Section 4.1.1. Inputs for EQ6 simulation of water/basalt reaction hydrochemistry are described in Section 4.1.2.

Modeling results are consistent with assuming that once intrusion occurs, waste packages in Zone 1 provide no further protection for the waste. However, for packages in Zone 2, Section 6.5.2.1 and 6.5.2.2 show that the intrusion will have minimal effect.

(3) Uncertainty is adequately represented in parameter development for conceptual models, process-level models, and alternative conceptual models considered in developing the assessment abstraction of mechanical disruption of engineered barriers. This may be done either through sensitivity analyses or use of conservative limits.

Alternative conceptual models that were considered in the development of the model of igneous intrusion impacts on waste packages and waste forms are described in Section 6.4. Uncertainties in the modeling are described in Section 6.6, and specific descriptions are provided of process level uncertainties, including uncertainty in heat conduction analysis (Section 6.6.1) and uncertainty in geochemical modeling using EQ6 (Section 6.6.2). The restrictions to the use of the output data are located in Section 8.3.

Attachment I contains the verification for heat conduction and verification of the calculations used in assessing the effects of magma intrusion for regions in the repository host horizon.

(4) Where sufficient data do not exist, the definition of parameter values and conceptual models is based on appropriate use of expert elicitation, conducted in accordance with NUREG-1563 (Kotra et al. 1996). If other approaches are used, the U.S. Department of Energy adequately justifies their use.

Expert elicitation was not used in the development of the model of igneous activity impacts on waste packages and waste forms. 


\section{Acceptance Criterion 4: Model uncertainty is characterized and propagated through the model abstraction}

(1) Alternative modeling approaches of features, events, and processes are considered and are consistent with available data and current scientific understanding, and the results and limitations are appropriately considered in the abstraction.

Alternative conceptual models that were considered in the development of the model of igneous intrusion impacts on waste packages and waste forms are described in Section 6.4. Uncertainties in the modeling are described in Section 6.6, and specific descriptions are provided of process level uncertainties, including uncertainty in heat conduction analysis (Section 6.6.1) and uncertainty in geochemical modeling using EQ6 (Section 6.6.2). The restrictions to the use of the output data are located in Section 8.3.

(2) Consideration of conceptual model uncertainty is consistent with available site characterization data, laboratory experiments, field measurements, natural analog information and process-level modeling studies; and the treatment of conceptual model uncertainty does not result in an under-representation of the risk estimate.

Alternative conceptual models that were considered in the development of the model of igneous intrusion impacts on waste packages and waste forms are described in Section 6.4. Uncertainties in the modeling are described in Section 6.6, and specific descriptions are provided of process level uncertainties, including uncertainty in heat conduction analysis (Section 6.6.1) and uncertainty in geochemical modeling using EQ6 (Section 6.6.2). The restrictions to the use of the output data are located in Section 8.3. The documentation includes conservatism incorporated in the consideration of uncertainties and bounding values that result.

The representation of risk is a TSPA-LA responsibility. This report describes no results that could be used to evaluate the representation of risk from magma-drift and magma-waste package interactions.

(3) Appropriate alternative modeling approaches are investigated that are consistent with available data and current scientific knowledge, and appropriately consider their results and limitations using tests and analyses that are sensitive to the processes modeled.

Alternative conceptual models that were considered in the development of the model of igneous intrusion impacts on waste packages and waste forms are described in Section 6.4.

Attachment I contains verification for heat conduction and verification of the calculations used in assessing the effects of magma intrusion for regions in the repository host horizon.

\section{Acceptance Criterion 5: Model abstraction output is supported by objective comparisons}

(1) Models implemented in this total system performance assessment abstraction provide results consistent with output from detailed process-level models and/or empirical observations (laboratory and field testing and/or natural analogs). 
The waste package damage model for Zone 1 conservatively shows that all waste packages contacted by magma are damaged to the extent that they provide no further protection for the waste. Analog studies at erupting basaltic volcanoes suggest that this damage is possible. Waste packages in Zone 2 are expected to show no effects from conducted heat and volatile gases because the repository host rocks provide good insulation around the Zone 1 drifts, and corrosive gases are not expected to reach Zone 2 in concentrations that would damage the waste packages. The consistency of these results with site conditions and process models is described in Section 7.

(2) Outputs of mechanical disruption of engineered barrier abstractions reasonably produce or bound the results of corresponding process-level models, empirical observations, or both.

For waste packages in Zone 1, TSPA-LA assumes that the waste packages are damaged to the extent that they provide no further protection for the waste. This assumption represents a bound on process-level modeling further corroborated by the information in Section 6.5.1.1. Waste form modifications are consistent with documented experimental petrology studies and are, therefore, considered reasonable representations of processes that could occur following intrusion.

Waste packages in Zone 2 are expected to show no effects from conducted heat because the repository host rocks provide good insulation around the Zone 1 drifts. The consistency of these results with site conditions and process models is described in Section 7.

(3) Well documented procedures that have been accepted by the scientific community to construct and test the mathematical and numerical models are used to simulate mechanical disruption of engineered barriers.

The basis for the selection of EQ3/6 Version 7.2b and EQ6 Version 7.2bLV for the modeling of seepage water/basalt interactions is documented in Sections 3.1.1 and 3.1.2. Validation of the model and consistency with well-understood processes are described in Section 7. Documentation of the consistency of the development of the EQ3/6 code with documented procedures for the development of software is beyond the scope of this report. Such documentation should be available in the EQ6 manual (CRWMS M\&O 1998).

(4) Sensitivity analyses or bounding analyses are provided to support the total system performance assessment abstraction of mechanical disruption of engineered barriers that cover ranges consistent with site data, field or laboratory experiments and tests, and natural analog research.

Results from analyses using the base-case model are documented in Sections 6.5.1, 6.5.2, and 6.5.3. Consistency of the model with data from site studies, field and laboratory experiments and tests, and natural analog research is described in Section 7. Additional information about consistency of specific model components with site features and processes is provided in Section 6.6 in the discussion of uncertainties. 


\section{INPUTS AND REFERENCES}

\subsection{DOCUMENTS CITED}

Altman, W.D.; Donnelly, J.P.; and Kennedy, J.E. 1988a. Peer Review for High-Level Nuclear Waste Repositories: Generic Technical Position. NUREG-1297. Washington, D.C.: U.S. Nuclear Regulatory Commission. TIC: 200651.

Altman, W.D.; Donnelly, J.P.; and Kennedy, J.E. 1988b. Qualification of Existing Data for High-Level Nuclear Waste Repositories: Generic Technical Position. NUREG-1298. Washington, D.C.: U.S. Nuclear Regulatory Commission. TIC: 200652.

Audi, G. and Wapstra, A.H. 1995. Atomic Mass Adjustment, Mass List for Analysis. Upton, New York: Brookhaven National Laboratory, National Nuclear Data Center. TIC: 242718.

Best, M.G. 1982. Igneous and Metamorphic Petrology. New York, New York: W.H. Freeman and Company. TIC: 247662.

Brady, P.V. and Walther, J.V. 1989. "Controls on Silicate Dissolution Rates in Neutral and Basic pH Solutions at $25^{\circ} \mathrm{C}$." Geochimica et Cosmochimica Acta, 53, 2823-2830. New York, New York: Pergamon Press. TIC: 235216.

Brantley, S.L. and Chen, Y. 1995. "Chemical Weathering Rates of Pyroxenes and Amphiboles." Chapter 4 of Chemical Weathering Rates of Silicate Minerals. White, A.F. and Brantley, S.L., eds. Reviews in Mineralogy Volume 31. Washington, D.C.: Mineralogical Society of America. TIC: 222496.

BSC 2002. Thermal Conductivity of the Potential Repository Horizon Model Report. MDLNBS-GS-000005 REV 00. Las Vegas, Nevada: Bechtel SAIC Company.

ACC: MOL.20020923.0167. [160319]

BSC (Bechtel SAIC Company) 2003. Characterize Eruptive Processes at Yucca Mountain, Nevada. ANL-MGR-GS-000002 REV 01. Las Vegas, Nevada: Bechtel SAIC Company. ACC: DOC.20031218.0003. [166407]

BSC 2003. Dissolved Concentration Limits of Radioactive Elements. ANL-WIS-MD-000010 REV 02 Las Vegas, Nevada: Bechtel SAIC Company. ACC: DOC.20030624.0003. [163152]

BSC 2003. Clad Degradation - Summary and Abstraction for LA. ANL-WIS-MD-000021 REV 00. Las Vegas, Nevada: Bechtel SAIC Company. ACC: DOC.20030626.0002. [162153]

BSC 2003. Waste Form and In-Drift Colloids-Associated Radionuclide Concentrations: Abstraction and Summary. MDL-EBS-PA-000004 REV 00 ICN 01. Las Vegas, Nevada: Bechtel SAIC Company. ACC: DOC.20031222.0012. [166845]

BSC (Bechtel SAIC Company) 2003. Dike/Drift Interactions. MDL-MGR-GS-000005 REV 00. Las Vegas, Nevada: Bechtel SAIC Company. ACC: DOC.20031022.0001 [165923] 
BSC (Bechtel SAIC Company) 2003. Total System Performance Assessment-License Application Methods and Approach. TDR-WIS-PA-000006 REV 00 ICN 01. Las Vegas, Nevada: Bechtel SAIC Company. ACC: DOC.20031215.0001. [166296]

BSC (Bechtel SAIC Company) 2004. Errata 002 for Drift-Scale Coupled Processes (DST and THC Seepage) Models. MDL-NBS-HS-000001 REV 02. Las Vegas, Nevada: Bechtel SAIC Company. ACC: DOC.20030804.0004; DOC.20040219.0002; DOC.20040405.0005. [168848]

BSC (Bechtel SAIC Company) 2004. Atmospheric Dispersal and Deposition of Tephra from a Potential Volcanic Eruption at Yucca Mountain, Nevada. MDL-MGR-GS-000002 REV 00. Las Vegas, Nevada: Bechtel SAIC Company. ACC: DOC.20040218.0003. [167616]

BSC (Bechtel SAIC Company) 2004. Defense HLW Glass Degradation Model. ANL-EBS-MD000016 REV 01 ICN 01. Las Vegas, Nevada: Bechtel SAIC Company. ACC:

DOC.20040223.0006. [167619]

BSC (Bechtel SAIC Company) 2004. Errata 001 for Abstraction of Drift Seepage. MDL-NBSHS-000019 REV 00 ICN 01. Las Vegas, Nevada: Bechtel SAIC Company. ACC:

DOC.20031112.0002, DOC.20040223.0001. [167970]

BSC (Bechtel SAIC Company) 2004. Clad Degradation - FEPs Screening Arguments. ANLWIS-MD-000008 REV 01. Las Vegas, Nevada: Bechtel SAIC Company. ACC: DOC.20040322.0001. [165057]

BSC (Bechtel SAIC Company) 2004. Errata for Ventilation Model and Analysis Report. ANLEBS-MD-000030 REV 03 ICN 03, Errata 2. Las Vegas, Nevada: Bechtel SAIC Company. ACC: DOC.20031216.0002; DOC.20040202.0004; DOC.20040325.0003. [168720]

BSC (Bechtel SAIC Company) 2004. Technical Work Plan for Waste Form Degradation Modeling, Testing, and Analyses in Support of LA. TWP-WIS-MD-000008 Rev 02 ICN 04. Las Vegas, NV: Bechtel SAIC Company. ACC: DOC.20040218.0001. [167796]

BSC (Bechtel SAIC Company) 2004. Number of Waste Packages Hit by Igneous Intrusion. ANL-MGR-GS-000003 REV 00. Las Vegas, Nevada: Bechtel SAIC Company. ACC: DOC.20040323.0002. [164650]

Canori, G.F. and Leitner, M.M. 2003. Project Requirements Document. TER-MGR-MD-000001 REV 02. Las Vegas, Nevada: Bechtel SAIC Company. ACC: DOC.20031222.0006.

Carnahan, B.; Luther, H.A.; and Wilkes, J.O. 1990. Applied Numerical Methods. Malabar, Florida: Krieger Publishing. TIC: 224042.

Chapman, A.J. 1974. Heat Transfer. $3^{\text {rd }}$ Edition. New York, New York: Macmillan Publishing. TIC: 245061.

Chou, L. and Wollast, R. 1985. "Steady-State Kinetics and Dissolution Mechanisms of Albite." American Journal of Science, 285, 963-993. New Haven, Connecticut: Yale University, Kline Geology Laboratory. TIC: 223169. 
CRWMS M\&O (Civilian Radioactive Waste Management System Management and Operating Contractor) 1998. Software Qualification Report (SQR) Addendum to Existing LLNL Document UCRL-MA-110662 PT IV: Implementation of a Solid-Centered Flow-Through Mode for EQ6 Version 7.2B. CSCI: UCRL-MA-110662 V 7.2b. SCR: LSCR198. Las Vegas, Nevada: CRWMS M\&O. ACC: MOL.19990920.0169.

CRWMS M\&O 1999. Waste Package Behavior in Magma. CAL-EBS-ME-000002 REV 00. Las Vegas, Nevada: CRWMS M\&O. ACC: MOL.19991022.0201.

CRWMS M\&O 2001. Miscellaneous Waste-Form FEPs. ANL-WIS-MD-000009 REV 00 ICN 01. Las Vegas, Nevada: CRWMS M\&O. ACC: MOL.20010216.0006.

Davison, R.M.; DeBold, T.; and Johnson, M.J. 1987. "Corrosion of Stainless Steels." In Corrosion, Volume 13, Pages 547-565 of ASM Handbook. Formerly 9th Edition, Metals Handbook. [Materials Park, Ohio]: ASM International. TIC: 240704.

DOE (Department of Energy) 1982. Site Characterization Report for the Basalt Waste Isolation Project. DOE/RL 82-3. Three Volumes. Washington, D.C.: Department of Energy. ACC: MOL.20040120.0079.

Douglass, D.L. 1983. "The Corrosion of Ferritic Stainless Steels and High-Purity Fe-Cr Alloys in Basaltic Lava and Simulated Magmatic Gas." Oxidation of Metals, Vol. 20, (Nos. 3/4), pp. 161183. New York, New York: Plenum Press. TIC: 238278.

Ehrlich, S.A. and Douglass, D.L. 1982. The Effect of Molybdenum Plus Chromium on the Corrosion of Iron-, Nickel, and Cobalt-Base Alloys in Basaltic Lava and Simulated Magmatic Gas at $1150^{\circ} \mathrm{C}$. SAND82-7055. Albuquerque, New Mexico: Sandia National Laboratories. ACC: MOL.19981028.0003.

Einziger, R.E.; Marschman, S.C.; and Buchanan, H.C. 1991. "Spent-Fuel Dry-Bath Oxidation Testing." Nuclear Technology, 94, 383-393. Hinsdale, Illinois: American Nuclear Society. TIC: 246459.

Frankel, J.J. 1967. "Forms and Structures of Intrusive Basaltic Rocks." Basalts, the Poldervaart Treatise on Rocks of Basaltic Composition. Volume 1. Hess, H.H. and Poldervaart, A., eds. Pages 63-102. New York, New York: Interscience Publishers. TIC: 254505.

Gislason, S.R. and Eugster, H.P. 1987. "Meteoric Water-Basalt Interactions: A Laboratory Study." Geochimica et Cosmochimica Acta, Vol. 51, pp. 2827-2840. Tarrytown, NY: Pergamon Journals LTD.. TIC: 235295.

Gordon, B.M. 2003. Literature Review of Waste Package and Drip Shield Materials' Corrosion Performance in Magmatic-Type Environments. SIR-02-168, Rev. 0. San Jose, California: Structural Integrity Associates. ACC: MOL.20030414.0260.

Hahn, G.J. and Shapiro, S.S. 1967. Statistical Models in Engineering. New York, New York: John Wiley \& Sons. TIC: 247729. 
Hearn, P.P.; Steinkampf, W.C.; Bortleson, G.C.; and Drost, B.W. 1985. Geochemical Controls on Dissolved Sodium in Basalt Aquifers of the Columbia Plateau, Washington. USGS/WRI 844304. U.S. Geological Survey, Lakewood: Colorado. TIC: 230835.

Hem, J.D. 1985. Study and Interpretation of the Chemical Characteristics of Natural Water. 3rd Edition. Geological Survey Water-Supply Paper 2254. Washington, D.C.: U.S. Government Printing Office. ACC: NNA.19940427.0181.

Hillner, E.; Franklin, D.G.; and Smee, J.D. 1998. The Corrosion of Zircaloy-Clad Fuel Assemblies in a Geologic Repository Environment. WAPD-T-3173. West Mifflin, Pennsylvania: Bettis Atomic Power Laboratory. TIC: 237127.

Hofmann, P. and Kerwin-Peck, D. 1984. " $\mathrm{UO}_{2} /$ Zircaloy-4 Chemical Interactions from 1000 to $1700^{\circ} \mathrm{C}$ under Isothermal and Transient Temperature Conditions." Journal of Nuclear Materials, 124, 80-105. New York, New York: North-Holland. TIC: 253983.

Hollingsworth, E.H. and Hunsicker, H.Y. 1987. "Corrosion of Aluminum and Aluminum Alloys." In Corrosion, Volume 13, Pages 583-609 of Metals Handbook. 9th Edition. Metals Park, Ohio: ASM International. TIC: 209807.

Incropera, F.P. and DeWitt, D.P. 2002. Fundamentals of Heat and Mass Transfer. $5^{\text {th }}$ Edition. New York, New York: John Wiley \& Sons. TIC: 254280.

Klein, C. and Hurlbut, C.S., Jr. 1999. Manual of Mineralogy. $21^{\text {st }}$ Edition, Revised. New York, New York: John Wiley \& Sons. TIC: 246258.

Kotra, J.P.; Lee, M.P.; Eisenberg, N.A.; and DeWispelare, A.R. 1996. Branch Technical Position on the Use of Expert Elicitation in the High-Level Radioactive Waste Program. NUREG-1563. Washington, D.C.: U.S. Nuclear Regulatory Commission. TIC: 226832.

Li, G.; Peacor, D.R.; Coombs, D.S.; and Kawachi, Y. 1997. "Solid Solution in the Celadonite Family: The New Minerals Ferroceladonite, $\mathrm{K}_{2} \mathrm{Fe}^{2}{ }_{2}+\mathrm{Fe}_{2}{ }_{2}+\mathrm{Si}_{8} \mathrm{O}_{20}(\mathrm{OH})_{4}$, and Ferroaluminoceladonite, $\mathrm{K}_{2} \mathrm{Fe}_{2}{ }_{2}+\mathrm{Al}_{2} \mathrm{Si}_{8} \mathrm{O}_{20}(\mathrm{OH})_{4}$." American Mineralogist, 82, (5-6), 503-511. Washington, D.C.: Mineralogical Society of America. TIC: 252472.

Li, J.; Lowenstein, T.K.; and Blackburn, I.R. 1997. "Responses of Evaporite Mineralogy to Inflow Water Sources and Climate During the Past 100 k.y. in Death Valley, California." Geological Society of America Bulletin, 109, (10), 1361-1371. Boulder, Colorado: Geological Society of America. TIC: 247723.

Lichtner, P.C.; Keating, G.; and Carey, B. 1999. A Natural Analog for Thermal-HydrologicalChemical Coupled Processes at the Proposed Nuclear Waste Repository at Yucca Mountain, Nevada. LA-13610-MS. Los Alamos, New Mexico: Los Alamos National Laboratory. TIC: 246032.

Lide, D.R., ed. 2002. CRC Handbook of Chemistry and Physics. 83rd Edition. Boca Raton, Florida: CRC Press. TIC: 253582. 
MacDonald, G.A. 1967. "Forms and Structures of Extrusive Basaltic Rocks." Basalts, the Poldervaart Treatise on Rocks of Basaltic Composition. Volume 1. Hess, H.H. and Poldervaart, A., eds. Pages 1-62. New York, New York: Interscience Publishers. TIC: 254505.

Mankins, W.L. and Lamb, S. 1990. "Nickel and Nickel Alloys." In Volume 2, Properties and Selection: Nonferrous Alloys and Special-Purpose Materials, Pages 428-445 of ASM Handbook. Formerly Tenth Edition, Metals Handbook. [Materials Park, Ohio]: ASM International. TIC: 241059.

McCright, R.D. 1998. Corrosion Data and Modeling, Update for Viability Assessment. Volume 3 of Engineered Materials Characterization Report. UCRL-ID-119564, Rev. 1.1. Livermore, California: Lawrence Livermore National Laboratory. ACC: MOL.19980806.0177.

NRC (U.S. Nuclear Regulatory Commission) 2003. Yucca Mountain Review Plan, Final Report. NUREG-1804, Rev. 2. Washington, D.C.: U.S. Nuclear Regulatory Commission, Office of Nuclear Material Safety and Safeguards. TIC: 254568.

Parrington, J.R.; Knox, H.D.; Breneman, S.L.; Baum, E.M.; and Feiner, F. 1996. Nuclides and Isotopes, Chart of the Nuclides. $15^{\text {th }}$ Edition. San Jose, California: General Electric Company and KAPL, Inc. TIC: 233705.

Perry, F.V. and Straub. K.T. 1996. Geochemistry of the Lathrop Wells Volcanic Center. LA13113-MS. Los Alamos, New Mexico:. Los Alamos National Laboratory. ACC:

MOL.19961015.0079.

Roberts, W.L.; Campbell, T.J.; and Rapp, G.R., Jr. 1990. Encyclopedia of Minerals. $2^{\text {nd }}$ Edition. New York, New York: Van Nostrand Reinhold. TIC: 242976.

Todreas, N.E. and Kazimi, M.S. 1990. Nuclear Systems I, Thermal Hydraulic Fundamentals. New York, New York: Hemisphere Publishing. TIC: 226511.

Tole, M.P.; Lasaga, A.C.; Pantano, C.; and White, W.B. 1986. "The Kinetics of Dissolution of Nepheline ( $\left.\mathrm{NaAlSiO}_{4}\right)$." Geochimica et Cosmochimica Acta, 50, (3), 379-392. New York, New York: Pergamon Press. TIC: 253992.

Valsami-Jones, E.; Ragnarsdottir, K.V.; Putnis, A.; Bosbach, D.; Kemp, A.J.; and Cressey, G. 1998. "The Dissolution of Apatite in the Presence of Aqueous Metal Cations at pH 2-7." Chemical Geology, 151, 215-233. [New York, New York]: Elsevier. TIC: 255204.

Vaniman, D.T.; Crowe, B.M.; and Gladney, E.S. 1982. "Petrology and Geochemistry of Hawaiite Lavas from Crater Flat, Nevada." Contributions to Mineralogy and Petrology, 80, 341-357. Berlin, Germany: Springer-Verlag. TIC: 201799.

Westrich, H.R. 1990. "Materials Compatibility Studies for the Magma Energy Extraction Project." Geothermics, 19, (4), 341-357. Elmsford, New York: Pergamon Press. TIC: 254234. 
White, D.E.; Hem, J.D.; and Waring, G.A. 1980. "Chemical Composition of Subsurface Waters." Chapter F of Data of Geochemistry. 6th Edition. Geological Survey Professional Paper 440-F. Washington, D.C.: U.S. Government Printing Office. TIC: 249975.

White, A.F.; Peterson, M.L.; and Hochells, M.F., Jr. 1994. "Electrochemistry and Dissolution Kinetics of Magnetite and Ilmenite." Geochimica et Cosmochimica Acta, 58, (8), 1859-1875. Oxford, United Kingdom: Elsevier. TIC: 246373.

Wogelius, R.A. and Walther, J.V. 1991. "Olivine Dissolution at $25^{\circ} \mathrm{C}$ : Effects of $\mathrm{pH}, \mathrm{CO}_{2}$, and Organic Acids." Geochimica et Cosmochimica Acta, 55, (4), 943-954. New York, New York: Pergamon Press. TIC: 236732.

Wolery, T.J. and Daveler, S.A. 1992. EQ6, A Computer Program for Reaction Path Modeling of Aqueous Geochemical Systems: Theoretical Manual, User's Guide, and Related Documentation (Version 7.0). UCRL-MA-110662 PT IV. Livermore, California: Lawrence Livermore National Laboratory. ACC: MOL.19980701.0459.

Yau, T.L. and Webster, R.T. 1987. "Corrosion of Zirconium and Hafnium." In Corrosion, Volume 13, Pages 707-721 of Metals Handbook. 9th Edition. Metals Park, Ohio: ASM International. TIC: 209807.

\subsection{CODES, STANDARDS, REGULATIONS, AND PROCEDURES}

10 CFR 63. Energy: Disposal of High-Level Radioactive Wastes in a Geologic Repository at Yucca Mountain, Nevada. Readily available.

AP-2.14Q, Rev. 3, ICN 0. Document Review. Washington, D.C.: U.S. Department of Energy, Office of Civilian Radioactive Waste Management. ACC: DOC.20030827.0018.

AP-6.1Q, Rev. 7, ICN 2. Document Control. Washington, D.C.: U.S. Department of Energy, Office of Civilian Radioactive Waste Management. ACC: DOC.20030929.0009.

AP-17.1Q, Rev. 3, ICN 2. Records Management. Washington, D.C.: U.S. Department of Energy, Office of Civilian Radioactive Waste Management. ACC: DOC.20040407.0004.

LP-SI.11Q-BSC, Rev. 0, ICN 0. Software Management. Washington, D.C.: U.S. Department of Energy, Office of Civilian Radioactive Waste Management. ACC: DOC.20040225.0007.

AP-SV.1Q, Rev. 1, ICN 1. Control of the Electronic Management of Information. Washington, D.C.: U.S. Department of Energy, Office of Civilian Radioactive Waste Management. ACC: DOC.20040308.0001.

AP-SIII.10Q, Rev. 2, ICN 3. Models. Washington, D.C.: U.S. Department of Energy, Office of Civilian Radioactive Waste Management. ACC: DOC.20040407.0001. 


\subsection{SOURCE DATA, LISTED BY DATA TRACKING NUMBER}

LB0207REVUZPRP.002. Matrix Properties for UZ Model Layers Developed from Field and Laboratory Data. Submittal date: 07/15/2002.

LB0310AMRU0120.001. Supporting Calculations and Analysis for Seepage Abstraction and Summary of Abstraction Results. Submittal date: 10/23/2003.

MO0006J13WTRCM.000. Recommended Mean Values of Major Constituents in J-13 Well Water. Submittal date: 06/07/2000.

MO0302SPATHDYN.000. Thermodynamic Data Input Files - Data0.YMP.R2. Submittal date: $02 / 05 / 2003$.

MO0307SEPFEPS4.000. LA FEP List. Submittal date: 07/31/2003.

MO0310SPAEBSCB.003. EBS Chemistry Binning Abstraction Results of the THC Seepage Model. Submittal date: 10/15/03.

SN0307T0510902.003. Updated Heat Capacity of Yucca Mountain Stratigraphic Units.

Submittal date: 07/15/2003.

\subsection{OUTPUT DATA, LISTED BY DATA TRACKING NUMBER}

DTN. MO0402SPAHWCIG.002. Heat and Water Chemistry Output from Igneous Intrusion. Submittal date: $02 / 23 / 2004$.

\subsection{SOFTWARE CODES}

Software Code: ASPRIN. V1.0. 10487-1.0-00.

Software Code: EQ3/6. V7.2b. LLNL: UCRL-MA-110662.

Software Code: EQ6, Version 7.2bLV. V7.2bLV. 10075-7.2bLV-00.

\section{ATTACHMENTS}

Attachment I Verification of Heat Conduction Model Simulation Calculations

Attachment II EQ6 Mineral Dissolution Rates

Attachment IIITwo Attached CD-ROMS

Attachment IVFile Listing of Attached CD-ROMS 


\section{ATTACHMENT I}

\section{VERIFICATION OF HEAT CONDUCTION MODEL SIMULATION CALCULATIONS}

\section{I.1 HEAT FLOW MODEL}

A one-dimensional second order partial differential equation (Chapman 1974, p. 137), subject to initial temperature (due to the constant heat content) and a far field temperature boundary condition applies to the problem of magma intrusion:

$$
k\left[\frac{1}{r} \cdot \frac{\partial T}{\partial r}+\frac{\partial^{2} T}{\partial r^{2}}\right]=\rho \cdot C_{p} \cdot \frac{\partial T}{\partial t}
$$

The temperature distribution for a magma flow filling a Zone 1 emplacement drift can be estimated using a one-dimensional unsteady radial heat conduction model, subject to constant heat content. The magma is considered to be at an initial intrusive temperature of $1150^{\circ} \mathrm{C}$ (BSC 2003 [DIRS:166407]). The magma fills the drift entirely and instantaneously, and then the temperature spatially and temporally dissipates. The temperature of the drift wall and the farfield is considered to be $25^{\circ} \mathrm{C}$, and up to $200^{\circ} \mathrm{C}$, at the time of the intrusion. The heat transfer thermal properties of the magma are considered to be the same as those for the densely welded tuff for a first order analysis.

Carnahan et al. (1990, p. 462) provides finite difference expression approximations to first and second order derivatives for the radial heat conduction problem. The governing equation may be expressed as:

$$
\frac{1}{r_{i}} \cdot\left(\frac{T_{i+1}^{\prime}-T_{i-1}^{\prime}}{2 \cdot \Delta r}\right)+\frac{1}{\Delta r^{2}} \cdot\left[T_{i+1}^{\prime}+T_{i-1}^{\prime}-2 \cdot T_{i}^{\prime}\right]=\frac{1}{\alpha} \cdot \frac{T_{i}-T_{i}^{\prime}}{\Delta t}
$$

Using the following definition of thermal diffusivity (Incropera and DeWitt 2002, p. 59):

$$
\alpha=\frac{k}{\rho C_{p}}
$$

where

$\Delta t$ is the change in time (time-step) in years

$r_{i}$ is the total distance to the center of the cylinder (units: $\mathrm{m}$ )

$\Delta r$ is the change in distance from the center of the cylinder in one time-step (units: $\mathrm{m}$ )

$T_{i} \quad$ is the temperature at distance $\mathrm{r}_{\mathrm{i}}$ from the center of the cylinder $\left({ }^{\circ} \mathrm{C}\right)$

$T^{\prime}{ }_{i}$ is the temperature from the previous time-step at a distance of $\mathrm{r}_{\mathrm{i}}$ from the center of the cylinder

$T^{\prime}{ }_{i+1}$ is the temperature from the previous time-step at a distance of $r_{i+1}$ from the center of the cylinder

$T_{i-1}^{\prime}$ is the temperature from the previous time-step at a distance of $\mathrm{r}_{\mathrm{I}-1}$ from the center of the cylinder

$\alpha$ is the thermal diffusivity of the rock mass (and thus the magma) ( $\mathrm{m}^{2} /$ year) 
$k \quad$ is the thermal conductivity of the rock mass (and thus the magma) $(\mathrm{W} / \mathrm{m} \cdot \mathrm{K}$ )

$\rho$ is the density $\left(\mathrm{kg} / \mathrm{m}^{3}\right)$

$C_{p}$ is the specific heat $(\mathrm{J} / \mathrm{kg} \cdot \mathrm{K})$

Factoring the expression to express $T_{i}$ in terms of $T_{i}^{*}, T_{i-1}^{*}$, and $T_{i+1}^{N}$ in an explicit finite difference calculation:

$$
T_{i}=\alpha \cdot \Delta t \cdot\left[\frac{1}{r_{i} \cdot 2 \cdot \Delta r}+\frac{1}{\Delta r^{2}}\right] \cdot T_{i+1}^{\prime}+\alpha \cdot \Delta t \cdot\left[\frac{-1}{r_{i} \cdot 2 \cdot \Delta r}+\frac{1}{\Delta r^{2}}\right] \cdot T_{i-1}^{\prime}-\frac{2 \alpha \cdot \Delta t \cdot T_{i}^{\prime}}{\Delta r^{2}}+T_{i}^{\prime}
$$

\section{Radial Equation $\left(\mathbf{r}_{\mathbf{i}}>\mathbf{0}\right)$}

A simple explicit finite difference calculation was set up in Microsoft Excel based upon the second order finite difference expression for radial flow. The stability of the calculation was confirmed by using an energy balance check within the spreadsheet. The explicit finite difference calculation can be simplified by defining the coefficients for $T_{i+1}^{\prime}, T_{i-1}^{\prime}$, and $T_{i}^{\prime}$ as $\alpha^{\prime}$, $\beta$ ', and $\gamma^{\prime}$, respectively:

$$
\begin{gathered}
\alpha^{\prime}=\left[\frac{1}{r_{i} \cdot 2 \cdot \Delta r}+\frac{1}{\Delta r^{2}}\right] \\
\beta^{\prime}=\left[\frac{-1}{r_{i} \cdot 2 \cdot \Delta r}+\frac{1}{\Delta r^{2}}\right] \\
\gamma^{\prime}=\left(-\frac{2}{\Delta r^{2}}\right)
\end{gathered}
$$

The explicit finite difference expression (Equation I-4) then becomes:

$$
T_{i}=\alpha \cdot \Delta t \cdot\left[\alpha^{\prime} \cdot T_{i+1}^{\prime}+\beta^{\prime} \cdot T_{i-1}^{\prime}+\gamma^{\prime} \cdot T_{i}^{\prime}\right]+T_{i}^{\prime}
$$

The far-field temperature boundary condition at a distance of 150 meters (approximately $10 \mathrm{~m}$ less than twice the drift spacing) is set to a constant ambient temperature of $25^{\circ} \mathrm{C}$. Additional calculations look at ambient temperatures up to $200^{\circ} \mathrm{C}$.

Centerline Equation $\left(r_{i}=0\right)$

To obtain an equation for the centerline temperature, a finite difference expression at the center of the model sets the insulated temperature boundary condition equal to the centerline temperature $\left(T_{i-1}^{i}=T_{i+1}\right)$.

$$
T_{i}=\alpha \cdot \Delta t \cdot\left[\frac{1}{r_{i} \cdot 2 \cdot \Delta r}+\frac{1}{\Delta r^{2}}\right] \cdot T_{i+1}^{\prime}+\alpha \cdot \Delta t \cdot\left[\frac{-1}{r_{i} \cdot 2 \cdot \Delta r}+\frac{1}{\Delta r^{2}}\right] \cdot T_{i+1}^{\prime}-\frac{2 \alpha \cdot \Delta t \cdot T_{i}^{\prime}}{\Delta r^{2}}+T_{i}^{\prime}
$$

Simplifying this equation: 


$$
T_{i}=\left[\frac{2 \alpha \cdot \Delta t}{\Delta r^{2}}\right] \cdot\left[T_{i+1}^{\prime}-T_{i}^{\prime}\right]+T_{i}^{\prime}
$$

The model was implemented by entering Equations I-4 and I-7 into Microsoft Excel spreadsheets in Attachment III (Disc 1, "Heat" folder). The required thermal diffusivity $(\alpha)$ was calculated using the method discussed below.

\section{Thermal Diffusivity}

Assessment of the effects of temperatures of intruded magma (intruded into Zone 1 drifts) on Zone 2 waste packages requires the rock mass thermal diffusivity, which in turn requires an estimate of the rock mass volumetric heat capacity and thermal conductivity of the welded tuff at the repository horizon.

The volumetric heat capacity was calculated using an equation derived in Ventilation Model and Analysis Report (BSC 2004 [DIRS:168720], Equation II-15).

$$
C_{r o c k}=\frac{S \cdot \frac{\phi_{m}}{1-\phi_{m}} C_{v w}+\rho_{g} \cdot C_{p}}{\left(1+\frac{\phi_{m}}{1-\phi_{m}}+\frac{\phi_{l}}{1-\phi_{l}} \cdot\left(1+\frac{\phi_{m}}{1-\phi_{m}}\right)\right)}
$$

Simplifying this equation:

$$
C_{\text {rock }}=\frac{S \cdot \frac{\phi_{m}}{1-\phi_{m}} C_{\nu w}+\rho_{g} \cdot C_{p}}{\left(1+\frac{\phi_{l}}{1-\phi_{l}}\right) \cdot\left(1+\frac{\phi_{m}}{1-\phi_{m}}\right)}
$$

where

$C_{\text {rock }}$ volumetric heat capacity of the rock mass $\left(\mathrm{J} / \mathrm{m}^{3} \cdot \mathrm{K}\right)$

$S \quad$ saturation $(\mathrm{S}=0$ : dry; $\mathrm{S}=1$ : wet $)$

$\phi_{m} \quad$ matrix porosity

$\phi_{l} \quad$ lithophysal porosity

$C_{v w}$ volumetric heat capacity of water $\left(\mathrm{J} / \mathrm{m}^{3} \cdot \mathrm{K}\right)$

$\rho_{g} \quad$ grain density of solids $\left(\mathrm{kg} / \mathrm{m}^{3}\right)$

$C_{p} \quad$ specific heat capacity of solids $(\mathrm{J} / \mathrm{kg} \cdot \mathrm{K})$

The saturation in this heat flow calculation is either completely dry (no water; $S=0$ ), or completely wet (matrix is completely filled with water; $S=1$ ). Real conditions of saturation are not so absolute; unsaturated conditions really lie between 10 and 20 percent saturation (DTN: LB0207REVUZPRP.002), and fully saturated conditions do not consider the lithophysae to be filled with water. 
The Yucca Mountain Project assessed the thermal conductivity of the potential repository horizon for spatial variability and uncertainty of thermal conductivity in the host horizon (BSC 2002 [DIRS:160319], Table 7-10). Table I-1 presents the properties taken from that report for the rock units near the repository horizon.

Table I-1. Summary of Primary Thermal Conductivity Statistics

\begin{tabular}{|c|c|c|c|c|c|c|}
\hline$\underset{\text { Unit }}{\text { Stratigraphic }}$ & $\begin{array}{c}\text { Bulk Dry Rock } \\
\text { Mass Thermal } \\
\text { Conductivity } \\
(\mathrm{W} / \mathrm{m} \cdot \mathrm{K})\end{array}$ & $\begin{array}{c}\text { Bulk Wet Rock } \\
\text { Mass Thermal } \\
\text { Conductivity } \\
\text { (W/m.K) }\end{array}$ & $\begin{array}{l}\text { Matrix } \\
\text { Porosity }\end{array}$ & $\begin{array}{l}\text { Lithophysal } \\
\text { Porosity }\end{array}$ & $\begin{array}{l}\text { Dry Bulk } \\
\text { Density } \\
\left(\mathrm{kg} / \mathrm{m}^{3}\right)\end{array}$ & $\begin{array}{c}\text { Specific Heat } \\
\text { Capacity of } \\
\text { Solids } \\
\mathrm{J} /(\mathbf{k g} \cdot \mathrm{K}) \\
\end{array}$ \\
\hline & $\boldsymbol{K}_{\boldsymbol{r}}$ & $\boldsymbol{k}_{\boldsymbol{r}}$ & $\phi_{m}$ & $\phi_{1}$ & $\rho_{\mathrm{bd}}$ & $C_{p}$ \\
\hline Tptpul & 1.18 & 1.77 & 0.17 & 0.12 & 1830 & 934 \\
\hline Tptpmn & 1.42 & 2.07 & 0.13 & 0.03 & 2150 & 932 \\
\hline Tptp\|l & 1.28 & 1.89 & 0.15 & 0.09 & 1980 & 933 \\
\hline Tptpln & 1.49 & 2.13 & 0.11 & 0.03 & 2210 & 933 \\
\hline
\end{tabular}

Source: BSC 2002 [DIRS:160319], Table 7-10, DTN:SN0307T0510902.003

NOTE: Porosity is the ratio of void volume to total rock volume, and has units of $\mathrm{m}^{3}$ void $/ \mathrm{m}^{3}$ rock.

The volume heat capacity of water $\left(C_{v w}\right)$ is calculated for saturated water at $62^{\circ} \mathrm{C}$ by multiplying the density of water $\left(\mathrm{kg} / \mathrm{m}^{3}\right)$ to the specific heat of water $(\mathrm{J} / \mathrm{kg} \cdot \mathrm{K})$ (Incropera and DeWitt 2002, pp. 58 and 59). Such that:

$$
C_{v w}=C_{P} \cdot \rho
$$

where

$\rho$ density of water $\left(1 / \mathrm{v}_{\mathrm{f}}\right) \quad 982.3\left(\mathrm{~kg} / \mathrm{m}^{3}\right)$

$C_{p}$ specific heat capacity $\quad 4186 \mathrm{~J} / \mathrm{kg} \cdot \mathrm{K}$

(Incropera and DeWitt 2002, p. 924, Table A.6)

The grain density of solids can be calculated from the dry bulk density $\left(\rho_{b d}\right)$ and the porosities of the matrix and lithophysae using the following equation from Thermal Conductivity of the Potential Repository Horizon Model Report (BSC 2002 [DIRS:160319], p. 41, Equation 6-4):

$$
\rho_{b d}=\left(1-\phi_{l}\right)\left(1-\phi_{m}\right) \rho_{g}
$$

Solving for the grain density of solids:

$$
\rho_{g}=\frac{\rho_{b d}}{\left(1-\phi_{l}\right)\left(1-\phi_{m}\right)}
$$

After plugging in the required values into Equation I-9 and solving for $C_{\text {rock, }}$, the thermal diffusivity can be calculated by combining Equation I-3 with Equation I-10: 


$$
\alpha=\frac{k}{C_{\text {rock }}}
$$

Note: The units of watts are converted to joules $(\mathrm{W}=\mathrm{J} / \mathrm{s})$, and then seconds converted to years, since $\Delta t$ is in terms of years.

Table I-2 contains all of the values calculated using the values presented in Table I-1, and Equation 10 through Equation 13, which were then used in the heat transfer explicit finite difference calculation.

Table 1-2. Summary of Volumetric Heat Capacity and Thermal Diffusivity Calculations

\begin{tabular}{|l|c|c|c|c|c|}
\hline $\begin{array}{c}\text { Stratigraphic } \\
\text { Unit }\end{array}$ & $\begin{array}{c}\text { Grain Density } \\
\text { of Solids } \\
\left(\mathbf{k g} / \mathbf{m}^{\mathbf{3}}\right)\end{array}$ & $\begin{array}{c}\text { Dry Volumetric } \\
\text { Heat Capacity } \\
\left(\mathbf{J} /\left(\mathbf{m}^{\mathbf{3}} \cdot \mathbf{K}\right)\right.\end{array}$ & $\begin{array}{c}\text { Wet Volumetric } \\
\text { Heat Capacity } \\
\left(\mathbf{J} / \mathbf{m}^{\mathbf{3}} \cdot \mathbf{K}\right)\end{array}$ & $\begin{array}{c}\text { Dry Thermal } \\
\text { Diffusivity } \\
\left(\mathbf{m}^{\mathbf{2}} / \mathbf{y r}\right)\end{array}$ & $\begin{array}{c}\text { Wet Thermal } \\
\text { Diffusivity } \\
\left(\mathbf{m}^{\mathbf{2}} / \mathbf{y r} \mathbf{r}\right)\end{array}$ \\
\hline & $\boldsymbol{\rho}_{\mathbf{g}}$ & $\boldsymbol{C}_{\text {rock }}$ & $\boldsymbol{C}_{\text {rock }}$ & $\boldsymbol{\alpha}$ & $\boldsymbol{\alpha}$ \\
\hline Tptpul & 2504 & 1709220.0 & 2335595.2 & 21.84 & 23.98 \\
\hline Tptpmn & 2532 & 2003800 & 2528980 & 22.35 & 25.88 \\
\hline Tptpll & 2551 & 1847340 & 2414589 & 21.84 & 24.69 \\
\hline Tptpln & 2548 & 2061930 & 2491536 & 22.80 & 26.98 \\
\hline
\end{tabular}

NOTE: Calculated in Attachment III (Disc 1, "Heat" folder).

\section{I.2 HEAT FLOW MODEL UNCERTAINTY ANALYSIS OF PEAK TEMPERATURE IN THE ROCK MASS AT A DISTANCE OF $10 \mathrm{M}$}

The generation of system moments allows a determination of the relative importance of each component variable by examining the magnitude of its partial derivative. Hahn and Shapiro (1967, p. 229) provide an expression for the mean system performance (for example the maximum temperature at a radius of $10 \mathrm{~m}$ from the drift with magma) through the expression under the assumption that the parameters are independent for the composite model:

$$
E(z)=h\left(\left(E\left(x_{1}\right), E\left(x_{2}\right), . . E\left(x_{n}\right)\right)+\frac{1}{2} \cdot \sum_{i=1}^{n} \frac{\partial^{2} h}{\partial x_{i}^{2}} \cdot \operatorname{Var}\left(x_{i}\right)\right.
$$

where

$E(z)=$ Expectation for the System Performance

$E\left(x_{i}\right)=$ Expectation of the Component Variables

$x_{i} \ldots x_{n}=$ Component Variables

$h()=$ Functional relationship between the component variables and the system performance

Hahn and Shapiro (1967, p. 231) present the following relationship for the variance in which the higher order moments are not used: 


$$
\operatorname{Var}(z)=\sum_{i=1}^{n}\left(\frac{\partial h}{\partial x_{i}}\right)^{2} \cdot \operatorname{Var}\left(x_{i}\right)
$$

This relation is frequently a satisfactory approximation to calculating the variance for independent parameters.

The peak temperature at a radius of $10 \mathrm{~m}$ for the constant heat content process depends on the rock mass thermal conductivity and thermal diffusivity that in turn depend on the solids thermal conductivity; the solids specific heat capacity; the solids grain density; the matrix porosity; the matrix saturation; and the lithophysal porosity. This set of parameters is taken as the independent set of parameters.

Table I-3 presents the evaluation of the system variance. The values for mean and standard deviation were obtained from Ventilation Model and Analysis Report (BSC 2004 [DIRS:168720], Section 6.11).

Table I-3. Sensitivity of Uncertainty in Input Parameters (with Standard Deviation for Use in Delta Method)

\begin{tabular}{|c|c|c|c|c|c|c|c|c|c|c|}
\hline \multirow{2}{*}{$\begin{array}{c}\text { Input/Design } \\
\text { Parameter }\end{array}$} & \multirow{2}{*}{$\begin{array}{l}\text { Mean } \\
\text { Value }\end{array}$} & \multirow{2}{*}{$\begin{array}{l}\text { Standard } \\
\text { Deviation } \\
\end{array}$} & \multicolumn{2}{|c|}{$\begin{array}{c}\text { Rock Mass } \\
\text { Thermal } \\
\text { Conductivity a }\end{array}$} & \multicolumn{2}{|c|}{$\begin{array}{c}\text { Rock Mass } \\
\text { Thermal } \\
\text { Diffusivity } \\
\end{array}$} & \multicolumn{3}{|c|}{ Peak Temperature } & \multirow{2}{*}{$\begin{array}{c}\text { Percent } \\
\text { Contribution } \\
\end{array}$} \\
\hline & & & Plus & Minus & Plus & Minus & Plus & Minus & Variance & \\
\hline $\begin{array}{l}\text { Solids Thermal } \\
\text { Conductivity }(\mathrm{W} /(\mathrm{m} \cdot \mathrm{K})\end{array}$ & 2.603 & 0.3413 & 2.02 & 1.62 & 26.68 & 21.48 & 78.17 & 78.12 & 5.55E-04 & $0 \%$ \\
\hline $\begin{array}{l}\text { Solids Grain Density } \\
\left(\mathrm{kg} / \mathrm{m}^{3}\right)\end{array}$ & 2593 & 138 & 1.82 & 1.82 & 23.14 & 25.16 & 78.13 & 78.15 & 8.54E-05 & $0 \%$ \\
\hline $\begin{array}{l}\text { Solids Specific Heat } \\
\text { Capacity }(\mathrm{J} /(\mathrm{kg} \cdot \mathrm{K}) \\
\end{array}$ & 930 & 170 & 1.82 & 1.82 & 21.09 & 28.15 & 78.11 & 78.16 & $4.50 \mathrm{E}-04$ & $0 \%$ \\
\hline Matrix Porosity & $14.86 \%$ & $3.40 \%$ & 1.74 & 1.91 & 22.59 & 25.79 & 78.13 & 78.16 & $2.08 \mathrm{E}-04$ & $0 \%$ \\
\hline Matrix Saturation & $90.50 \%$ & $10 \%$ & 1.89 & 1.76 & 24.39 & 23.82 & 78.14 & 78.14 & 5.91E-06 & $0 \%$ \\
\hline Lithophysal Porosity & $8.83 \%$ & $5.40 \%$ & 1.72 & 1.93 & 24.13 & 24.09 & 78.14 & 78.14 & $1.92 \mathrm{E}-08$ & $0 \%$ \\
\hline Initial Temperature* & 1150 & 35.51 & 1.82 & 1.82 & 24.11 & 24.11 & 73.23 & 79.04 & 2.81 & $100 \%$ \\
\hline \multicolumn{11}{|c|}{\begin{tabular}{|l|l|l|} 
Sum & 2.81 & $100 \%$ \\
\end{tabular}} \\
\hline \multicolumn{9}{|c|}{ Standard Deviation } & 1.68 & \\
\hline
\end{tabular}

NOTE: ${ }^{a}$ Calculated in "Heat Conduction - Uncertainty Analysis.xls" in "heat.zip ' in Attachment III (Disc 1).

The Method of Moments provides information as to the source of uncertainty from the individual variables. In Equation I-13, the variance of each individual variable $x_{i}$ is multiplied by the square of the derivative of the system function for that parameter. The square of the derivative represents the sensitivity of the system variance to the individual parameter. If the sensitivity, and the variance to an individual parameter are large, then the system variance is dominated by this contribution. Conversely, if the sensitivity, and the variance to an individual parameter are small, then the system variance is not influenced by this individual contribution.

Table I-3 represents the results of the analysis using the method of generating system moments. The analysis is performed by calculating the first order partial derivatives of temperature to the solids thermal conductivity $\left(k_{s}\right)$; the solids specific heat capacity $\left(\mathrm{C}_{\mathrm{p}}\right)$; the solids grain density $\left(\rho_{g}\right)$; matrix porosity $\left(\phi_{m}\right)$; the matrix saturation $\left(S_{m}\right)$; and the lithophysal porosity $\left(\phi_{l}\right)$. Each 
component is perturbed from its mean value by plus or minus one standard deviation while the other components are evaluated at their mean value. The rock mass thermal conductivity and the thermal diffusivity are then calculated based upon the relations for thermal conductivity and thermal diffusivity presented previously. The finite difference calculations are then performed and the peak temperature at a radius of $10 \mathrm{~m}$ is evaluated for the parameters. The first order partial derivatives are approximated for the mean values plus or minus one standard deviation for each component and then substituted into Equations I-14.

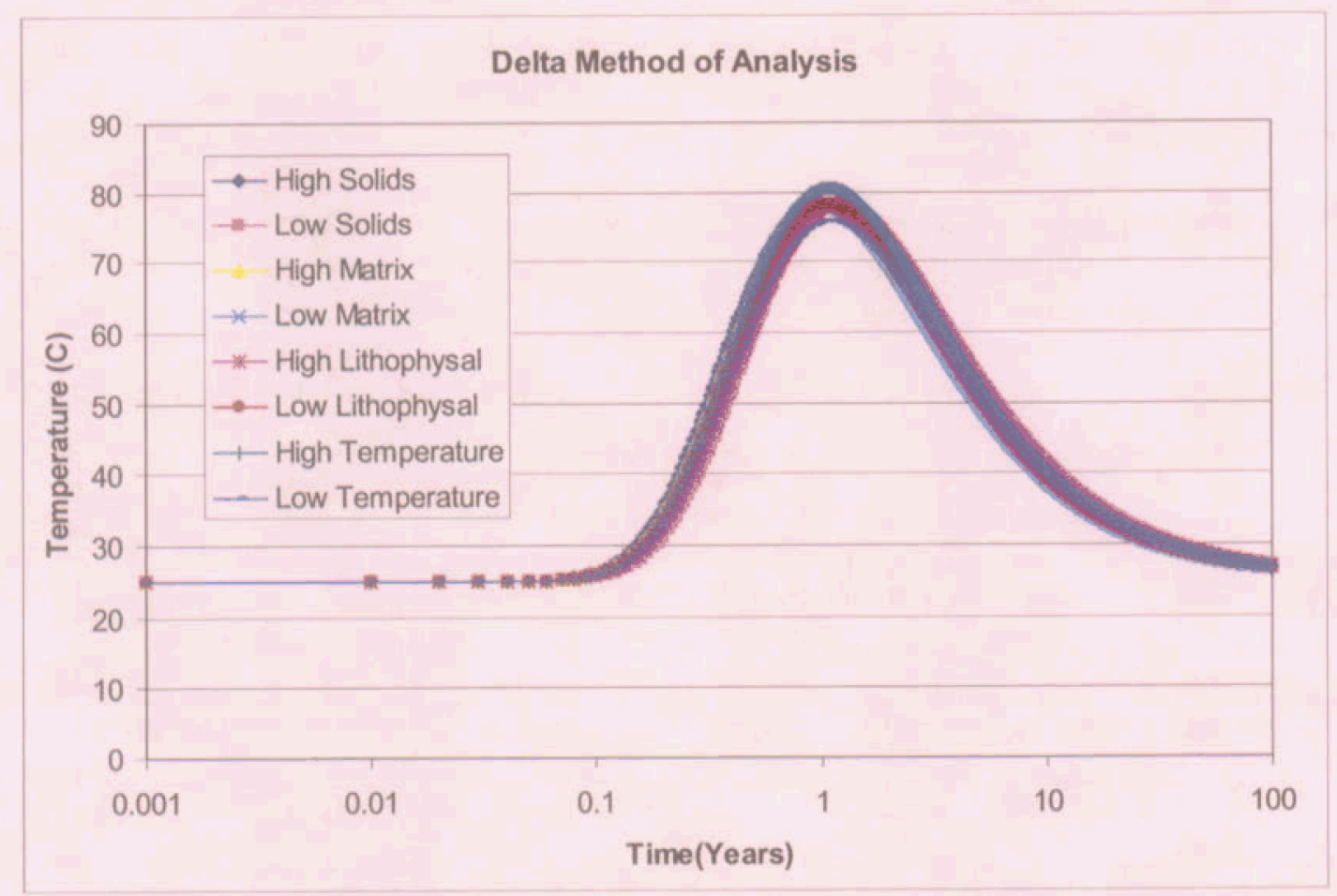

Figure 1-1. Peak Temperatures for Variations in Key Inputs

Figure I-1 shows that variations in key inputs other than initial temperature result in a shift in the time when the peak temperature occurs, but the actual peak temperature remains the same.

The contributions to variance are then calculated for each component as the product of the sensitivity time the variance. The contributions are then summed. The analysis provides information on the percent contributions to system variance from each of the component variables. The analysis suggests that the principal source of uncertainty is the initial temperature (100 percent of the uncertainty). The variance caused by the uncertainty of the initial temperature should be used as the uncertainty of the output temperatures, which is $\pm 3^{\circ} \mathrm{C}$. 
Igneous Intrusion Impacts on Waste Packages and Waste Forms

\section{INTENTIONALLY LEFT BLANK}




\section{ATTACHMENT II}

\section{EQ6 MINERAL DISSOLUTION RATES}

This attachment contains figures that show input values to, calculation of, and EQ6 rate comparisons of the rates for the dissolution of minerals in the EQ6 simulation of basalt/water interaction. Calculation of the mineral dissolution rates for EQ6 is as follows:

- Using Microsoft Excel, a trendline was added (linear) to each of the pH legs (i.e., low $\mathrm{pH}$ values were fit with one trendline and high $\mathrm{pH}$ values were fit with a different trendline). These linear fits are shown by the black trendlines in the figures. The linear equation for these lines is also presented as well as the rounded values used for the calculation of the rate for EQ6.

- EQ6 calculates the rate of dissolution at any $\mathrm{pH}$ by the following formula

$$
\text { Total Dissolution Rate }=\mathrm{k}_{1}\left[\mathrm{H}^{+}\right]^{\mathrm{S} 1}+\mathrm{k}_{2}\left[\mathrm{H}^{+}\right]^{\mathrm{S} 2}\left(\operatorname{moles} / \mathrm{cm}^{2} \cdot \mathrm{s}\right)
$$

where $\mathrm{k}_{1}$ and $\mathrm{k}_{2}$ represent the exponential of the intercept and S1 and S2 values represent the slope of the trendlines.

- The EQ6 curve (pH dependent dissolution rate) is calculated by using the above stated values to calculate the dissolution rate for each $\mathrm{pH}$ leg. These values are then combined to create one dissolution rate by the model.

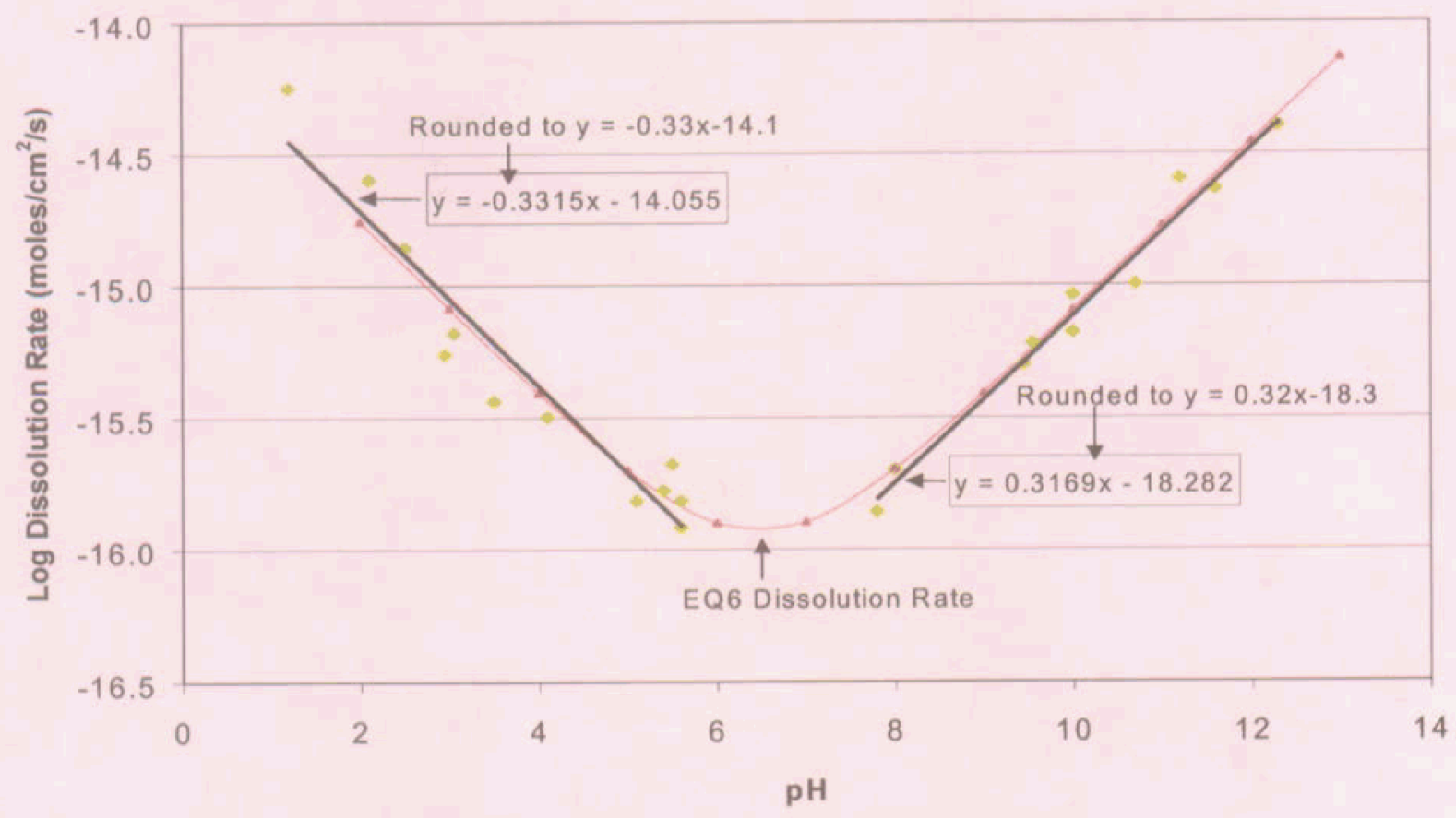

NOTE: Calculated in Spreadsheet "Aluminosilicate rates.xls" on Attachment III, Disc 1

Figure II-1. EQ6 Dissolution Rate of Albite (also used for Sanidine) 


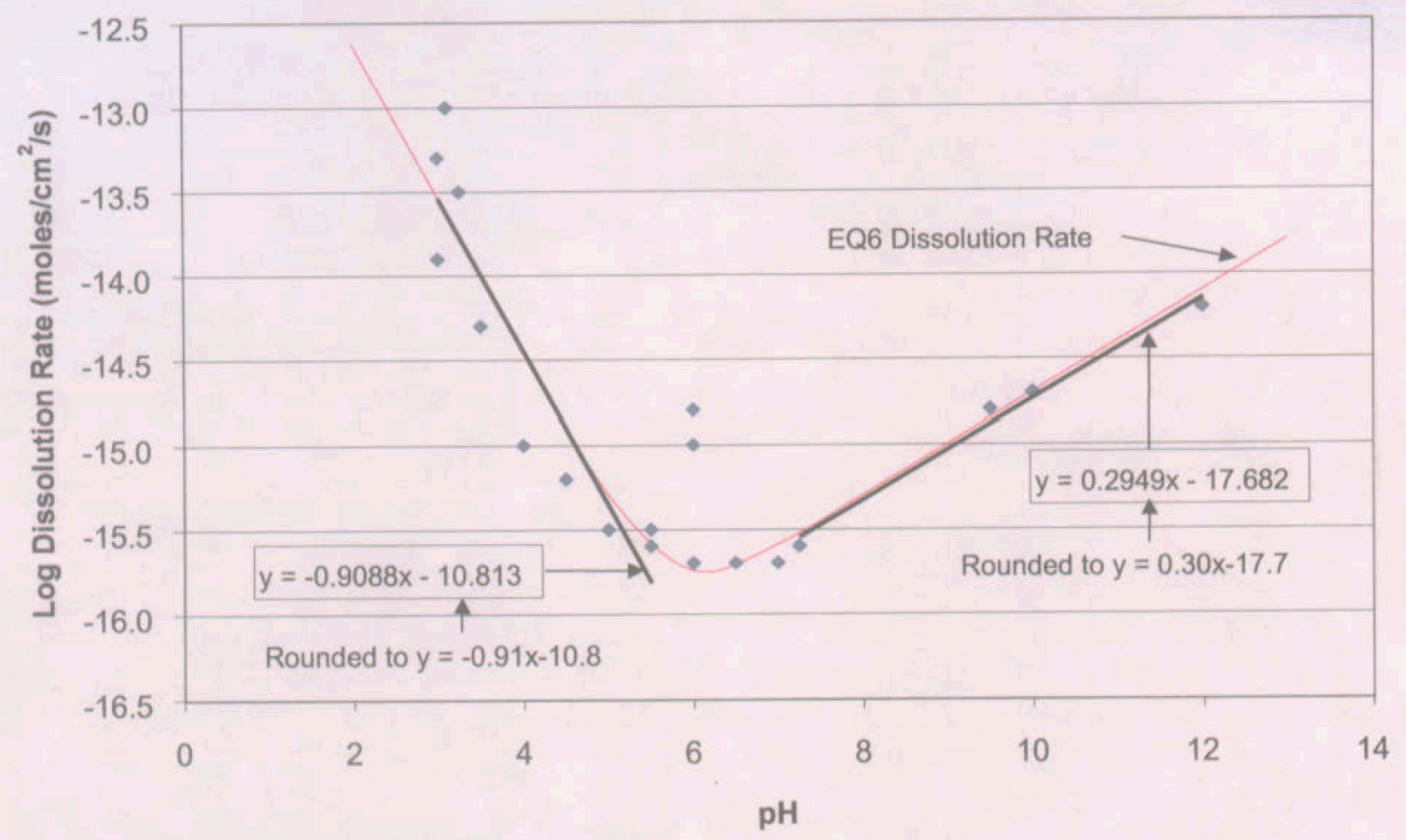

NOTE: Calculated in Spreadsheet "Aluminosilicate rates.xIs" on Attachment III, Disc 1

Figure II-2. EQ6 Dissolution Rate of Anorthite

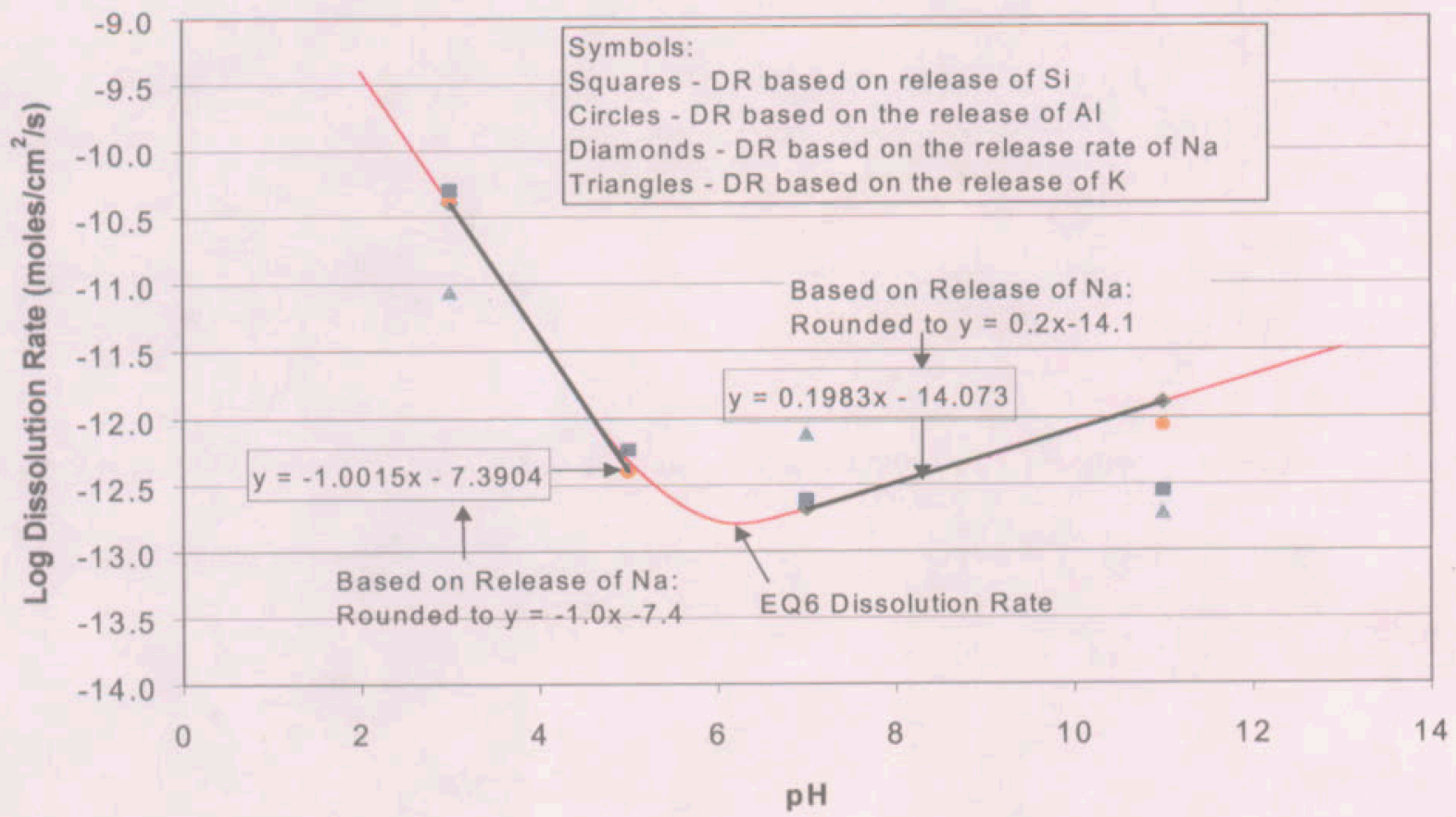

NOTE: Calculated in Spreadsheet "Aluminosilicate rates.xIs" on Attachment III, Disc 1 from Na release data found in Table 4-7. Release rates for $\mathrm{Si}, \mathrm{Al}$, and $\mathrm{K}$ can be found in Table II-1

Figure II-3. EQ6 Dissolution Rate of Nepheline 
Table II-1. Additional Nepheline Dissolution Rates Shown on Figure II-3

\begin{tabular}{|c|c|c|c|c|c|c|}
\hline \multirow[b]{2}{*}{$\mathrm{pH}$} & \multicolumn{2}{|c|}{ Based on release of $\mathrm{Si}$} & \multicolumn{2}{|c|}{ Based on release of Al } & \multicolumn{2}{|c|}{ Based on release of $K$} \\
\hline & $\begin{array}{c}\text { DR } \\
\left(\mathrm{mole} / \mathrm{cm}^{2} \mathrm{~s}\right)\end{array}$ & Log DR & $\begin{array}{c}\text { DR } \\
\left(\mathrm{mole} / \mathrm{cm}^{2} \mathrm{~s}\right)\end{array}$ & Log DR & $\begin{array}{c}\text { DR } \\
\left(\mathrm{mole} / \mathrm{cm}^{2} \mathrm{~s}\right)\end{array}$ & $\log D R$ \\
\hline 3 & $5.03 \mathrm{E}-11$ & -10.30 & 4.22E-11 & -10.37 & 8.61E-12 & -11.06 \\
\hline 5 & $5.78 \mathrm{E}-13$ & -12.24 & $3.94 \mathrm{E}-13$ & -12.40 & $5.81 \mathrm{E}-13$ & -12.24 \\
\hline 7 & $2.42 \mathrm{E}-13$ & -12.62 & $\ldots$ & …… & 7.50E-13 & -12.12 \\
\hline 11 & $2.78 \mathrm{E}-13$ & -12.56 & $8.61 E-13$ & -12.06 & $1.89 E-13$ & -12.72 \\
\hline
\end{tabular}

NOTE: DR from Tole et al., 1986, Table 2, Log DR calculated on "Aluminosilicate rates.xls" on Attachment III, Disc 1. DR = Dissolution Rate

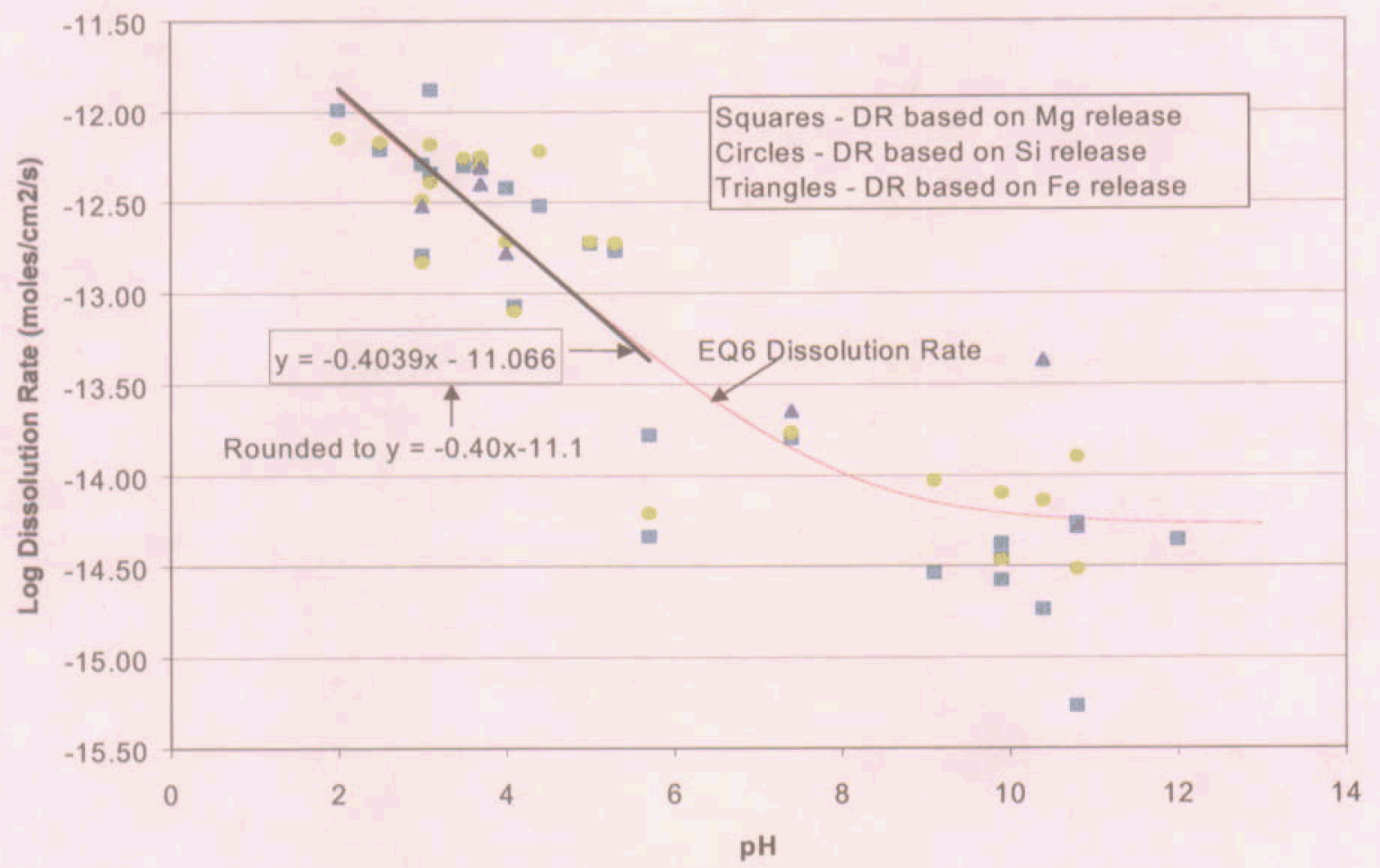

NOTE: Calculated in Spreadsheet "olivine rate.xIs" on Attachment III, Disc 1 from Mg release data found in Table 4-8. Release rates for Si and Fe can be found in Table II-2

Figure II-4. EQ6 Dissolution Rate of Olivine (Used for Forsterite and Fayalite) 
Igneous Intrusion Impacts on Waste Packages and Waste Forms

Table II-2. Additional Olivine Dissolution Rates Shown on Figure II-4

\begin{tabular}{|c|c|c|c|c|c|}
\hline \multicolumn{6}{|c|}{ Based on release of $\mathrm{Si}$} \\
\hline pH & $\begin{array}{c}\log \mathrm{DR} \\
\left(\mathrm{mole} / \mathrm{cm}^{2} \mathrm{~s}\right)\end{array}$ & $\mathrm{pH}$ & $\begin{array}{c}\log D R \\
\left(\mathrm{~mole} / \mathrm{cm}^{2} \mathrm{~s}\right)\end{array}$ & $\mathrm{pH}$ & $\begin{array}{c}\log \text { DR } \\
\left(m o l e / \mathrm{cm}^{2} \mathrm{~s}\right)\end{array}$ \\
\hline 4.1 & -13.10 & 5 & -12.72 & 3.1 & -12.18 \\
\hline 10.4 & -14.14 & 5.7 & -14.21 & 4 & -12.72 \\
\hline 7.4 & -13.77 & 2 & -12.15 & 3 & -12.49 \\
\hline 9.9 & -14.47 & 9.1 & -14.03 & 3.5 & -12.26 \\
\hline 9.9 & -14.10 & 3.7 & -12.30 & 3.1 & -12.39 \\
\hline 3.7 & -12.25 & 2.5 & -12.17 & 5.3 & -12.73 \\
\hline 10.8 & -14.52 & 4.4 & -12.22 & 10.8 & -13.90 \\
\hline 3 & -12.83 & & & & \\
\hline \multicolumn{6}{|c|}{ Based on release of $\mathrm{Fe}$} \\
\hline $\mathrm{pH}$ & $\begin{array}{c}\log \mathrm{DR} \\
\left(\mathrm{mole}^{2} \mathrm{~cm}^{2} \mathrm{~s}\right)\end{array}$ & $\mathrm{pH}$ & $\begin{array}{c}\log \text { DR } \\
\left(\mathrm{mole} / \mathrm{cm}^{2} \mathrm{~s}\right)\end{array}$ & $\mathrm{pH}$ & $\begin{array}{c}\log D R \\
\left(m o l e / \mathrm{cm}^{2} \mathrm{~s}\right)\end{array}$ \\
\hline 10.4 & -13.37 & 3.7 & -12.40 & 3 & -12.52 \\
\hline 7.4 & -13.65 & 4 & -12.78 & 10.8 & -14.29 \\
\hline 3.7 & -12.31 & & & & \\
\hline
\end{tabular}

NOTE: Log DR from Wogelius and Walther, Table 2

$\mathrm{DR}=$ Dissolution Rate

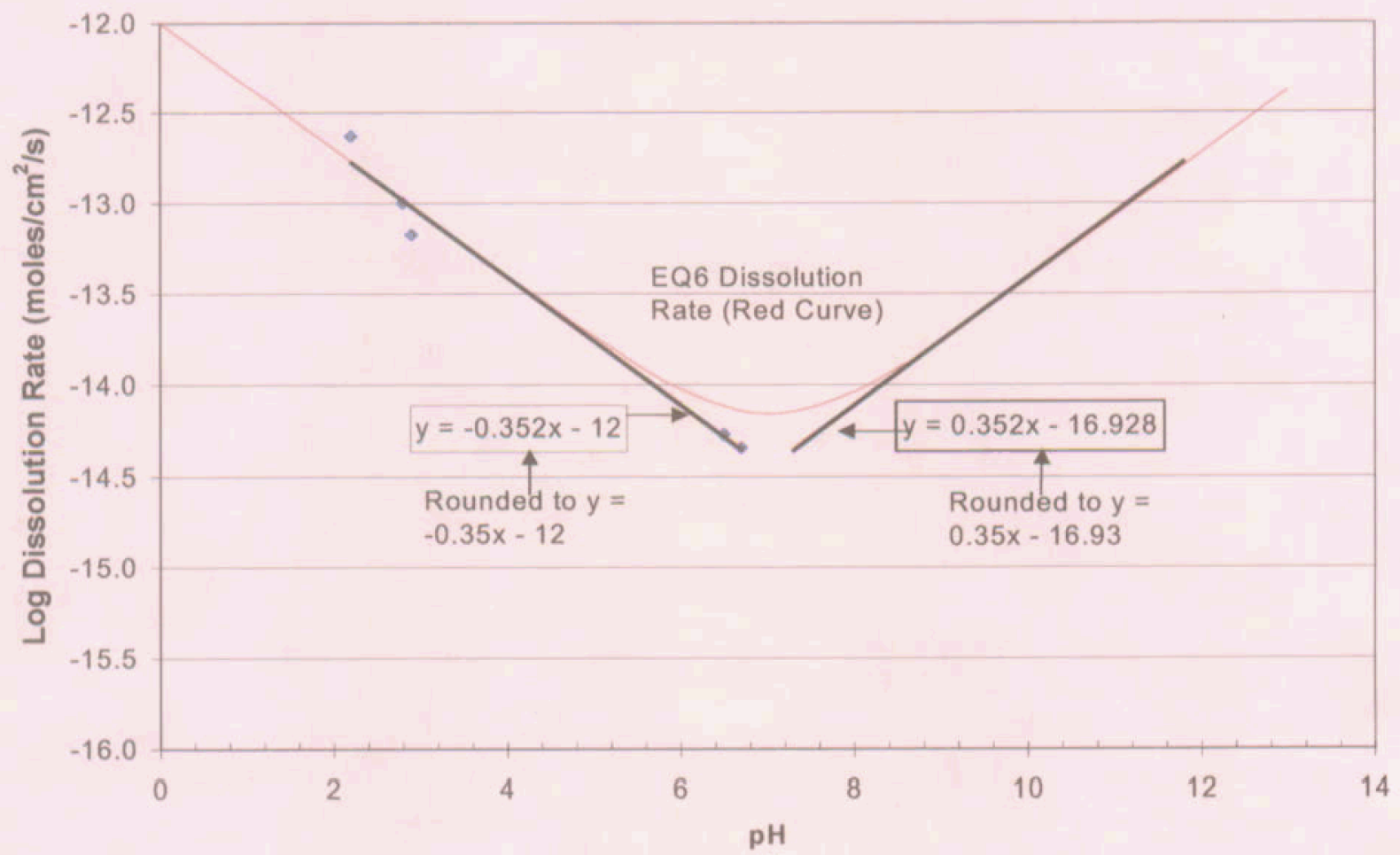

NOTE: Calculated in Spreadsheet "apatite rate.xIs" on Attachment III, Disc 1.

Figure II-5. EQ6 Dissolution Rate of Hydroxylapatite 


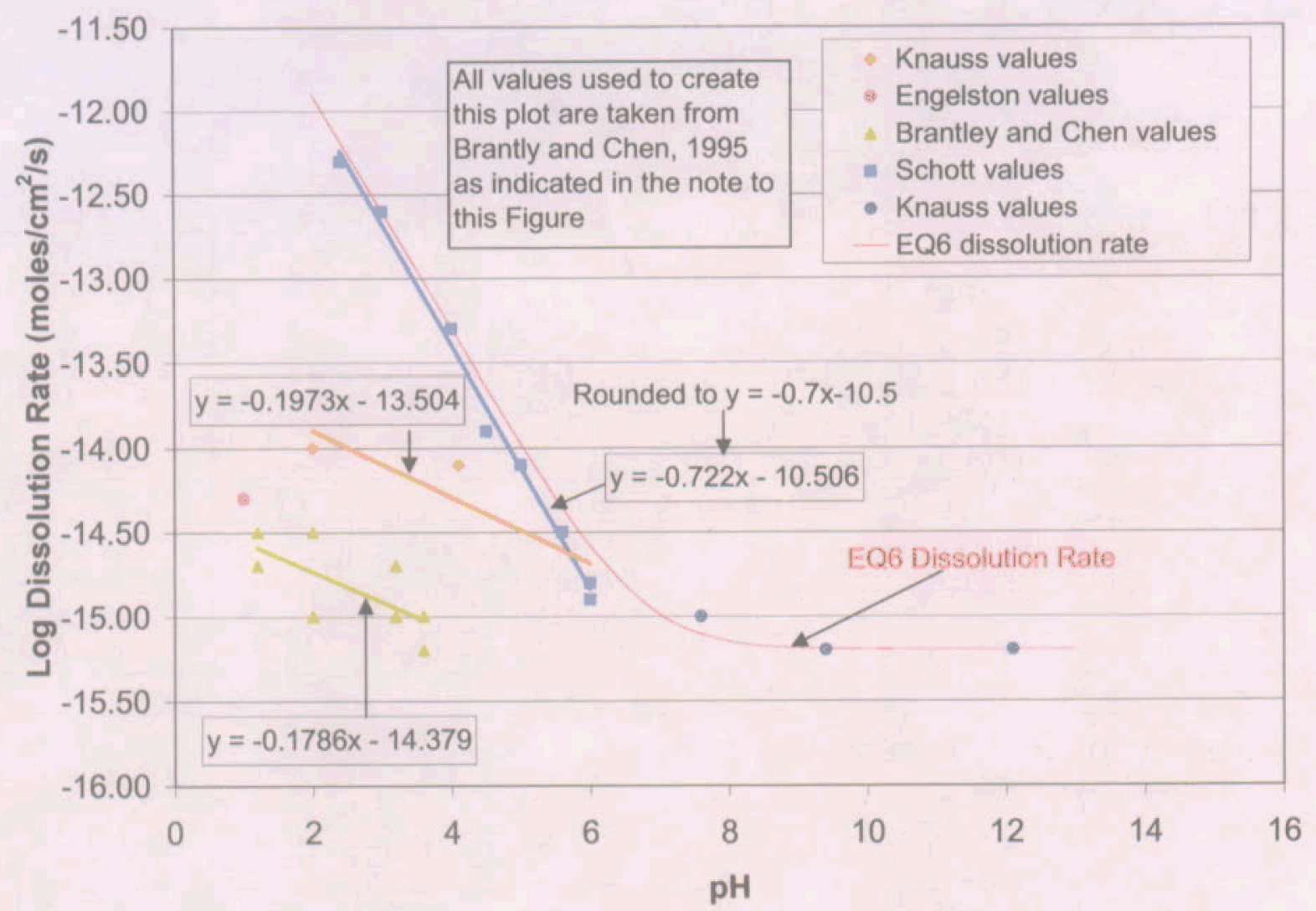

NOTE: All plotted data are from Table 1 of Brantley and Chen (1995), which is a compilation of dissolution data from different sources mentioned in the plot inset box. Calculated in Spreadsheet "pyroxene rates.x/s" on Attachment III, Disc 1, from Schott data found in Table 4-8. Other release rates shown on the plot can be found in Table ॥-3

Figure II-6. EQ6 Dissolution Rate of Diopside (Used for Hedenbergite)

Table II-3. Additional Diopside Dissolution Rates Shown on Figure II-6

\begin{tabular}{|c|c|c|c|c|c|}
\hline pH & $\begin{array}{c}\text { Log DR } \\
\left(\mathrm{mole} / \mathrm{cm}^{2} \mathrm{~s}\right)\end{array}$ & $\mathrm{pH}$ & $\begin{array}{c}\text { Log DR } \\
\left(\mathrm{mole} / \mathrm{cm}^{2} \mathrm{~s}\right)\end{array}$ & $\mathrm{pH}$ & $\begin{array}{c}\text { Log DR } \\
\left(\mathrm{mole} / \mathrm{cm}^{2} \mathrm{~s}\right)\end{array}$ \\
\hline \multicolumn{7}{|c|}{ Brantley and Chen, 1995 } \\
\hline 1.2 & -14.50 & 3.6 & -15.00 & 3.2 & -15.00 \\
\hline 2 & -14.50 & 1.2 & -14.70 & 3.6 & -15.20 \\
\hline 3.2 & -14.70 & 2 & -15.00 & 6 & -14.80 \\
\hline \multicolumn{7}{|c|}{ Knauss data presented in Brantley and Chen, 1995} \\
\hline 2 & -14.00 & 4.1 & -14.10 & 6 & 6 \\
\hline
\end{tabular}

NOTE: $\mathrm{DR}=$ Dissolution Rate 


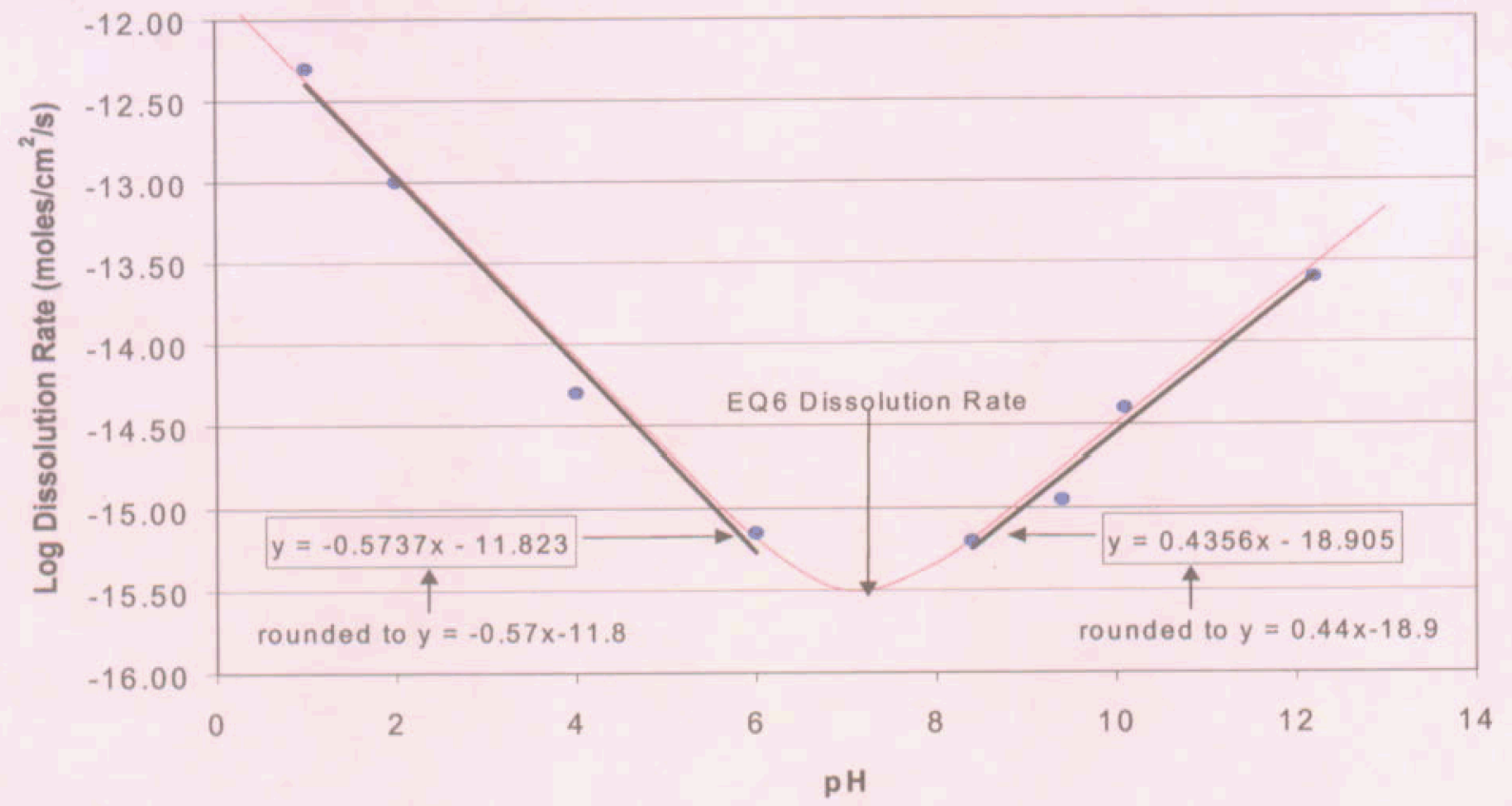

NOTE: Calculated in Spreadsheet "pyroxene rates.xls" on Attachment III, Disc 1.

Figure II-7. EQ6 Dissolution Rate of Enstatite

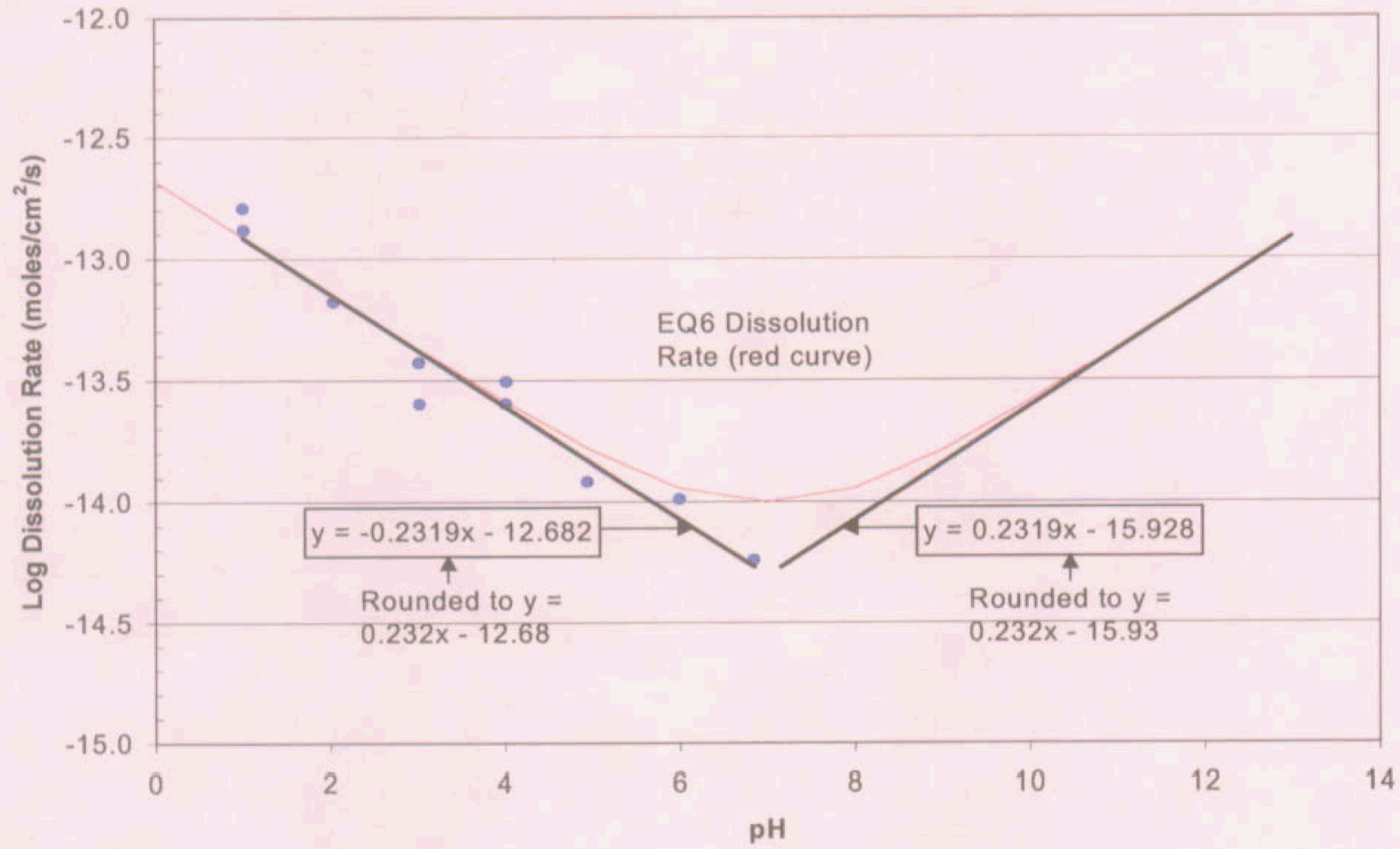

NOTE: Calculated in Spreadsheet "oxides rate.xls" on Attachment III, Disc 1.

Figure II-8. EQ6 Dissolution Rate of Magnetite 


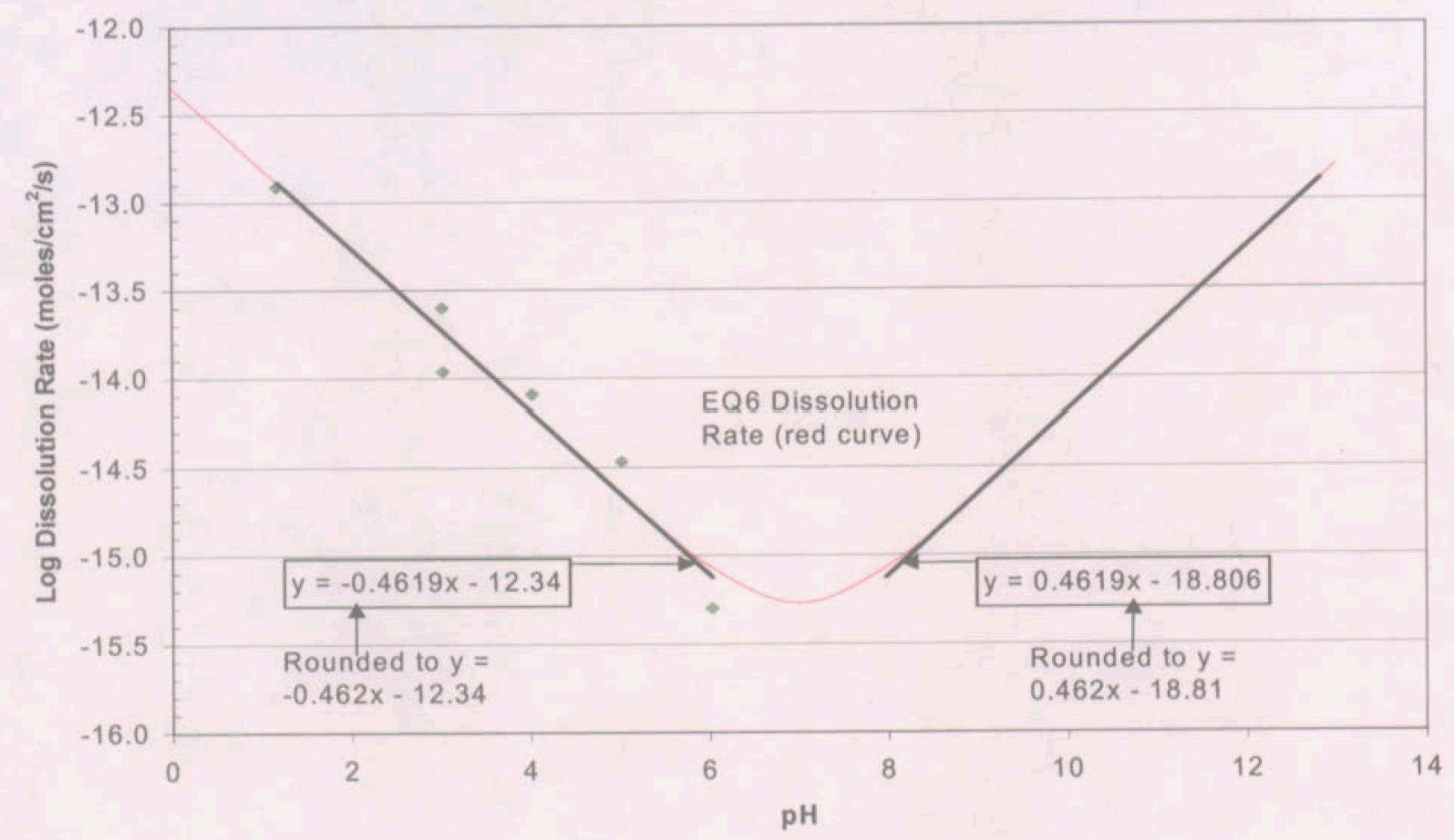

NOTE: Calculated in Spreadsheet "oxides rate.xIs" on Attachment III, Disc 1.

Figure II-9. EQ6 Dissolution Rate of IImenite

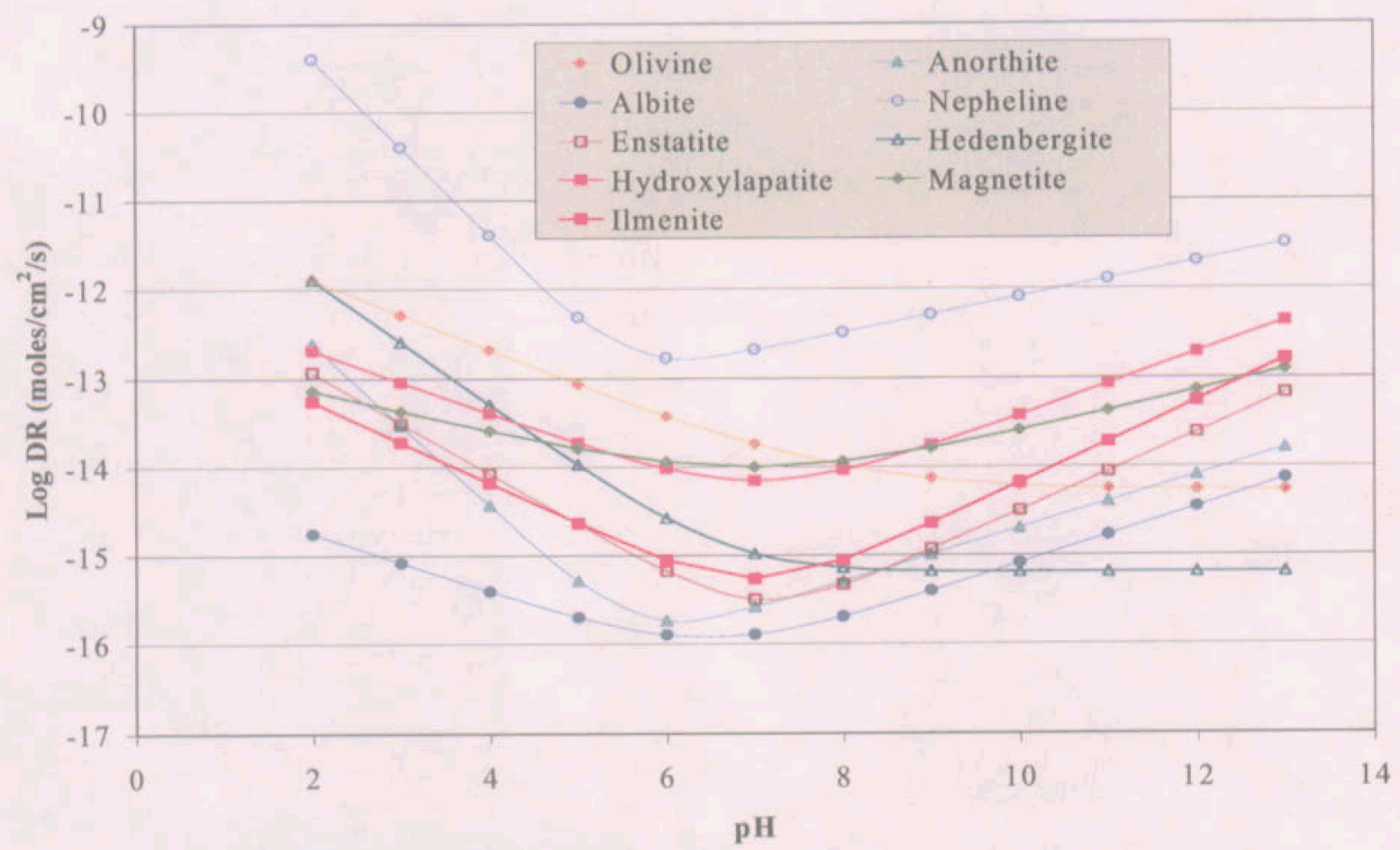

Note: Calculated in Spreadsheet "Diss-Rate Summary.xls" on Attachment III, Disc 1

Figure II-10. Comparison of Rates Used in EQ6 Calculations 
Igneous Intrusion Impacts on Waste Packages and Waste Forms

\section{ATTACHMENT III}

\section{TWO ATTACHED CD-ROMS}

See attached CD ROMS 


\section{ATTACHMENT IV}

\section{FILE LISTING OF ATTACHED CD-ROMS}

NOTE: The attached CD-ROMS contain files of various types. These are:

1) Excel files (extension $=x l s)$.

2) $\mathrm{EQ} 3 / 6$ input files (extensions $=3 \mathrm{i}$ or $6 \mathrm{i}$ ).

3) EQ3/6 output files (text, extension $=30$ or 60 ).

4) EQ3/6 pickup files (text, extension $=3 p$ or $6 p$ )

5) Tab-delimited text files (extension $=$ txt). These contain: total aqueous moles

(*.elem_aqu.txt); total moles in minerals and aqueous phase (*.elem_m_a.txt); total moles in minerals, aqueous phase, and remain special reactants (*.elem_tot.txt); and the total moles in minerals alone $\left({ }^{*}\right.$.elem min.txt). The *.elem_tot.txt and *.elem_min.txt also have the volume in $\mathrm{cm}^{3}$ of the minerals and total solids (including special reactants) in the system.

6) EQ6 text data file used for the calculations, named data0.sit.

7) ASPRIN output files (text, extension $=t x t$ ).

\section{Directory of CD-ROM 1 of 2}

Directory of $\mathrm{D}: 1$

\begin{tabular}{|c|c|c|c|}
\hline $12 / 05 / 2003$ & $03: 22 \mathrm{p}$ & $\langle\mathrm{DIR}\rangle$ & $\mathrm{CO} 2-2$ \\
\hline $12 / 16 / 2003$ & $09: 52 a$ & $\langle\mathrm{DIR}\rangle$ & $\mathrm{CO} 2-25$ \\
\hline $11 / 18 / 2003$ & $10: 44 a$ & $\langle\mathrm{DIR}\rangle$ & database \\
\hline $02 / 05 / 2004$ & $04: 45 p$ & $\langle\mathrm{DIR}\rangle$ & EQ3-6 Inputs \\
\hline $11 / 23 / 2003$ & $10: 24 a$ & $\langle\mathrm{DIR}>$ & Eq3-bin 8 \\
\hline $04 / 16 / 2004$ & $11: 33 a$ & $236,132,523$ & Heat.zip \\
\hline $01 / 21 / 2004$ & $02: 36 p$ & $\langle\mathrm{DIR}>$ & sensitivity \\
\hline $01 / 27 / 2004$ & $02: 50 p$ & $\langle\mathrm{DIR}>$ & water rate \\
\hline & 1 File (s) & $236,132,523$ & 3 bytes \\
\hline \multicolumn{4}{|c|}{ Directory of $\mathrm{D}: \backslash \mathrm{CO} 2-2$} \\
\hline $01 / 20 / 2004$ & $11: 32 a$ & $<\mathrm{DIR}>$ & asprin-2 \\
\hline $12 / 05 / 2003$ & $10: 49 a$ & 41,447 & $b 8 a \_2.6 i$ \\
\hline $12 / 05 / 2003$ & $11: 05 a$ & 955,077 & b8a_2.6o \\
\hline $12 / 05 / 2003$ & $11: 05 a$ & 38,172 & $\mathrm{~b} 8 \mathrm{a} \_2.6 \mathrm{p}$ \\
\hline $12 / 05 / 2003$ & $11: 05 a$ & 7,118 & b8a_2.elem_aqu.txt \\
\hline $12 / 05 / 2003$ & $11: 05 a$ & 6,525 & b8a_2.elem_min.txt \\
\hline $12 / 05 / 2003$ & $11: 05 a$ & 6,538 & b8a_2.elem_tot.txt \\
\hline
\end{tabular}




\begin{tabular}{|c|c|c|}
\hline $12 / 05 / 2003$ & $11: 05 a$ & 14,237 b8a_2.min_info.txt \\
\hline $12 / 05 / 2003$ & $10: 49 a$ & 41,449 b8b_2.6i \\
\hline $12 / 05 / 2003$ & $11: 43 a$ & $10,970,599$ b8b_2.6o \\
\hline $12 / 05 / 2003$ & $11: 43 a$ & 38,172 b8b_2.6p \\
\hline $12 / 05 / 2003$ & $11: 43 a$ & 53,100 b8b_2.elem_aqu.txt \\
\hline $12 / 05 / 2003$ & $11: 43 a$ & 48,523 b8b_2.elem_min.txt \\
\hline $12 / 05 / 2003$ & $11: 43 a$ & 48,536 b8b_2.elem_tot.txt \\
\hline $12 / 05 / 2003$ & $11: 43 a$ & 114,961 b8b_2.min_info.txt \\
\hline $12 / 05 / 2003$ & $10: 58 a$ & 41,449 b8f1_2.6i \\
\hline $12 / 05 / 2003$ & $11: 49 a$ & $4,644,445$ b8f1_2.6o \\
\hline $12 / 05 / 2003$ & $11: 49 a$ & $38,172 \mathrm{~b} 8 \mathrm{f} 1{ }^{2} 2.6 \mathrm{p}$ \\
\hline $12 / 05 / 2003$ & $11: 49 a$ & 28,724 b8f1_2.elem_aqu.txt \\
\hline $12 / 05 / 2003$ & $11: 49 a$ & 26,259 b8f1_2.elem_min.txt \\
\hline $12 / 05 / 2003$ & $11: 49 a$ & 26,272 b8f1_2.elem_tot.txt \\
\hline $12 / 05 / 2003$ & $11: 49 a$ & 57,605 b8f1_2.min_info.txt \\
\hline $12 / 05 / 2003$ & $10: 57 \mathrm{a}$ & 41,449 b8f2_2.6i \\
\hline $12 / 05 / 2003$ & $12: 02 p$ & $13,190,388$ b8f2_2.6o \\
\hline $12 / 05 / 2003$ & $12: 02 p$ & 37,844 b8f2_2.6p \\
\hline $12 / 05 / 2003$ & $12: 02 p$ & 78,584 b8f2_2.elem_aqu.txt \\
\hline $12 / 05 / 2003$ & $12: 02 p$ & 71,799 b8f2_2.elem_min.txt \\
\hline $12 / 05 / 2003$ & $12: 02 p$ & 71,812 b8f2_2.elem_tot.txt \\
\hline $12 / 05 / 2003$ & $12: 02 p$ & 151,179 b8f2_2.min_info.txt \\
\hline $12 / 05 / 2003$ & $01: 15 p$ & $38,172 \mathrm{~b} 8 \mathrm{p} \times 2.6 \mathrm{i}$ \\
\hline $12 / 05 / 2003$ & $03: 15 p$ & $677,295 \mathrm{~b} 8 \mathrm{p} \times 2.60$ \\
\hline $12 / 05 / 2003$ & $03: 15 p$ & $38,172 b 8 p \times 2.6 p$ \\
\hline $12 / 05 / 2003$ & $03: 15 p$ & 3,517 b8px2.elem_aqu.txt \\
\hline $12 / 05 / 2003$ & $03: 15 p$ & 3,236 b8px2.elem_min.txt \\
\hline $12 / 05 / 2003$ & $03: 15 p$ & 3,249 b8px2.elem_tot.txt \\
\hline $12 / 05 / 2003$ & $03: 15 p$ & 6,735 b8px2.min_info.txt \\
\hline $12 / 05 / 2003$ & $10: 49 a$ & 41,449 b8p_2.6i \\
\hline $12 / 05 / 2003$ & $12: 46 p$ & $13,044,899$ b8p_2.60 \\
\hline $12 / 05 / 2003$ & $12: 46 p$ & 38,172 b8p_2.6p \\
\hline $12 / 05 / 2003$ & $12: 46 p$ & 57,125 b8p_2.elem_min.txt \\
\hline $12 / 05 / 2003$ & $12: 46 p$ & 62,518 b8p_2.elem_aqu.txt \\
\hline $12 / 05 / 2003$ & $12: 46 \mathrm{p}$ & 57,138 b8p_2.elem_tot.txt \\
\hline $12 / 05 / 2003$ & $12: 46 p$ & 135,497 b8p_2.min_info.txt \\
\hline $12 / 05 / 2003$ & $10: 54 a$ & 41,449 b8s_2.6i \\
\hline
\end{tabular}


Igneous Intrusion Impacts on Waste Packages and Waste Forms

\begin{tabular}{|c|c|c|}
\hline $12 / 05 / 2003$ & $12: 55 p$ & $2,955,291$ b8s_2.60 \\
\hline $12 / 05 / 2003$ & $12: 55 p$ & 38,172 b8s_2.6p \\
\hline $12 / 05 / 2003$ & $12: 55 p$ & 14,887 b8s_2.elem_tot.txt \\
\hline $12 / 05 / 2003$ & $12: 55 p$ & 16.259 b8s_2.elem_aqu.txt \\
\hline $12 / 05 / 2003$ & $12: 55 p$ & 14,874 b8s_2.elem_min.txt \\
\hline $12 / 05 / 2003$ & $12: 55 p$ & 34,629 b8s_2.min_info.txt \\
\hline & 49 File (s) & $48,213,170$ bytes \\
\hline \multicolumn{3}{|c|}{ Directory of $\mathrm{D}: \backslash \mathrm{CO} 2-2 \backslash$ asprin-2 } \\
\hline $01 / 20 / 2004$ & $11: 32 \mathrm{a}$ & $55,018,496$ abstraction-2.xls \\
\hline $12 / 05 / 2003$ & $03: 25 p$ & 57,897 b8a_2.txt \\
\hline $12 / 05 / 2003$ & $03: 27 p$ & $1,449,609$ b8b_2.txt \\
\hline $12 / 05 / 2003$ & $03: 27 p$ & 452,881 b8f1_2.txt \\
\hline $12 / 05 / 2003$ & $03: 28 p$ & $1,438,592$ b8f2_2.txt \\
\hline $12 / 05 / 2003$ & $03: 29 p$ & 79,706 b8px2.txt \\
\hline $12 / 05 / 2003$ & $03: 29 p$ & $1,741,059$ b8p_2.txt \\
\hline $12 / 05 / 2003$ & $03: 30 p$ & 333,630 b8s_2.txt \\
\hline & 8 File (s) & $60,571,870$ bytes \\
\hline \multicolumn{3}{|c|}{ Directory of $\mathrm{D}: \backslash \mathrm{CO} 2-25$} \\
\hline $01 / 20 / 2004$ & $11: 33 a$ & asprin-25 \\
\hline $12 / 05 / 2003$ & $11: 06 a$ & 41,449 b8a_25.6i \\
\hline $12 / 05 / 2003$ & $01: 19 p$ & $1,060,855$ b8a_25.60 \\
\hline $12 / 05 / 2003$ & $01: 19 p$ & 38,174 b8a_25.6p \\
\hline $12 / 05 / 2003$ & $01: 18 p$ & 7,672 b8a_25.elem_aqu.txt \\
\hline $12 / 05 / 2003$ & $01: 18 p$ & 7,031 b8a_25.elem_min.txt \\
\hline $12 / 05 / 2003$ & $01: 18 p$ & 7,044 b8a_25.elem_tot.txt \\
\hline $12 / 05 / 2003$ & $01: 18 p$ & 16,086 b8a_25.min_info.txt \\
\hline $12 / 05 / 2003$ & $11: 08 a$ & 41,449 b8b_25.6i \\
\hline $12 / 05 / 2003$ & $01: 58 \mathrm{p}$ & $11,425,134$ b8b_25.6o \\
\hline $12 / 05 / 2003$ & $01: 58 p$ & 38,256 b8b_25.6p \\
\hline $12 / 05 / 2003$ & $01: 57 p$ & 51,319 b8b_25.elem_tot.txt \\
\hline $12 / 05 / 2003$ & $01: 57 p$ & 56,147 b8b_25.elem_aqu.txt \\
\hline $12 / 05 / 2003$ & $01: 57 p$ & 51,306 b8b_25.elem_min.txt \\
\hline $12 / 05 / 2003$ & $01: 57 p$ & 132,566 b8b_25.min_info.txt \\
\hline
\end{tabular}




\begin{tabular}{|c|c|c|c|}
\hline $12 / 05 / 2003$ & $11: 09 a$ & 41,448 & $\mathrm{~b} 8 \mathrm{f} 1 \_25.6 i$ \\
\hline $12 / 05 / 2003$ & $02: 03 p$ & $4,839,732$ & $\mathrm{~b} 8 \mathrm{f} 1 \_25.60$ \\
\hline $12 / 05 / 2003$ & $02: 03 p$ & 38,256 & $\mathrm{~b} 8 \mathrm{f1} 125.6 \mathrm{p}$ \\
\hline $12 / 05 / 2003$ & $02: 03 p$ & 27,284 & b8f1_25.elem_tot.txt \\
\hline $12 / 05 / 2003$ & $02: 03 p$ & 29,832 & b8f1_25.elem_aqu.txt \\
\hline $12 / 05 / 2003$ & $02: 03 p$ & 27,271 & b8f1_25.elem_min.txt \\
\hline $12 / 05 / 2003$ & $02: 03 p$ & 65,366 & b8f1_25.min_info.txt \\
\hline $12 / 05 / 2003$ & $11: 10 a$ & 41,449 & $\mathrm{~b} 8 \mathrm{f} 2 \_25.6 i$ \\
\hline $12 / 05 / 2003$ & $02: 19 p$ & $13,632,923$ & b8f2_25.6o \\
\hline $12 / 05 / 2003$ & $02: 19 p$ & 38,174 & $b 8 f 2 \_25.6 p$ \\
\hline $12 / 0.5 / 2003$ & $02: 19 p$ & 72,824 & b8f2_25.elem_tot.txt \\
\hline $12 / 05 / 2003$ & $02: 19 p$ & 79,692 & b8f2_25.elem_aqu.txt \\
\hline $12 / 05 / 2003$ & $02: 19 p$ & 72,811 & b8f2_25.elem_min.txt \\
\hline $12 / 05 / 2003$ & $02: 19 p$ & 169,716 & b8f2_25.min_info.txt \\
\hline $12 / 05 / 2003$ & $03: 20 p$ & 38,256 & $\mathrm{~b} 8 \mathrm{p} \times 25.6 i$ \\
\hline $12 / 05 / 2003$ & $03: 36 p$ & $1,059,213$ & $\mathrm{~b} 8 \mathrm{p} \times 25.60$ \\
\hline $12 / 05 / 2003$ & $03: 36 p$ & 38,256 & $b 8 p \times 25.6 p$ \\
\hline $12 / 05 / 2003$ & $03: 36 p$ & 4,754 & b8px25.elem_min.txt \\
\hline $12 / 05 / 2003$ & $03: 36 p$ & $5,179$. & b8px25.elem_aqu.txt \\
\hline $12 / 05 / 2003$ & $03: 36 p$ & 4,767 & b8px25.elem_tot.txt \\
\hline $12 / 05 / 2003$ & $03: 36 p$ & 9,809 & b8px25.min_info.txt \\
\hline $12 / 05 / 2003$ & $11: 12 a$ & 41,448 & b8p_25.6i \\
\hline $12 / 05 / 2003$ & $03: 03 p$ & $13,255,497$ & b8p_25.6o \\
\hline $12 / 05 / 2003$ & $03: 03 p$ & 38,256 & b8p_25.6p \\
\hline $12 / 05 / 2003$ & $03: 03 p$ & 152,050 & b8p_25.min_info.txt \\
\hline $12 / 05 / 2003$ & $03: 03 p$ & 64,180 & b8p_25.elem_aqu.txt \\
\hline $12 / 05 / 2003$ & $03: 03 p$ & 58,643 & b8p_25.elem_min.txt \\
\hline $12 / 05 / 2003$ & $03: 03 p$ & 58,656 & b8p_25.elem_tot.txt \\
\hline $12 / 05 / 2003$ & $11: 13 a$ & 41,449 & b8s_25.6i \\
\hline $12 / 05 / 2003$ & $03: 14 p$ & $3,520,354$ & b8s_25.6o \\
\hline $12 / 05 / 2003$ & $03: 14 p$ & 38,256 & b8s_25.6p \\
\hline $12 / 05 / 2003$ & $03: 14 p$ & 17,670 & b8s_25.elem_tot.txt \\
\hline $12 / 05 / 2003$ & $03: 14 \mathrm{p}$ & 19,306 & b8s_25.elem_aqu.txt \\
\hline $12 / 05 / 2003$ & $03: 14 \mathrm{p}$ & 17,657 & b8s_25.elem_min.txt \\
\hline \multirow[t]{2}{*}{$12 / 05 / 2003$} & $03: 14 \mathrm{p}$ & 44,302 & b8s_25.min_info.txt \\
\hline & 49 File (s) & $50,679,224$ & 4 bytes \\
\hline
\end{tabular}


Directory of $\mathrm{D}: \backslash \mathrm{CO} 2-25 \backslash$ asprin-25

\begin{tabular}{|c|c|c|}
\hline $01 / 20 / 2004$ & $11: 33 a$ & $57,953,792$ abstraction-25.xls \\
\hline $12 / 05 / 2003$ & $03: 25 p$ & 64,223 b8a_25.txt \\
\hline $12 / 05 / 2003$ & $03: 26 p$ & $1,478,786$ b8b_25.txt \\
\hline $12 / 05 / 2003$ & $03: 31 p$ & 460,250 b8f1_25.txt \\
\hline $12 / 05 / 2003$ & $03: 31 p$ & $1,445,671$ b8f2_25.txt \\
\hline $12 / 05 / 2003$ & $03: 37 p$ & 134,113 b8px25.txt \\
\hline $12 / 05 / 2003$ & $03: 32 \mathrm{p}$ & $1,741,062$ b8p_25.txt \\
\hline $12 / 05 / 2003$ & $03: 32 p$ & 391,981 b8s_25.txt \\
\hline
\end{tabular}

Directory of $\mathrm{D}: \backslash$ database

04/04/2003 10:33a

1 File (s)
2,719,044 data0.slt

$2,719,044$ bytes

Directory of $D: \backslash E Q 3-6$ Inputs

$\begin{array}{ll}01 / 20 / 2004 & 12: 01 p \\ 02 / 04 / 2004 & 10: 16 a \\ 02 / 23 / 2004 & 04: 17 p \\ 12 / 16 / 2003 & 11: 23 a \\ 01 / 20 / 2004 & 08: 41 a \\ 06 / 26 / 2003 & 09: 43 a \\ 11 / 19 / 2003 & 02: 50 p \\ 07 / 01 / 2003 & 03: 40 p\end{array}$

8 File (s)
56,832 Aluminosilicate rates.xls

27,136 apatite rate. $x 1 s$

79,872 basalt-separated.xls

20,992 conversions.xls

25,600 Diss-Rate Summary.xls

30,720 olivine rate. $x l s$

40,960 oxides rate.xls

39,936 pyroxene rates.xis

322,048 bytes

Directory of $D: \backslash E q 3-b i n 8$

$\begin{array}{ll}11 / 22 / 2003 & 12: 23 p \\ 11 / 22 / 2003 & 12: 24 p \\ 11 / 22 / 2003 & 12: 24 p \\ 11 / 23 / 2003 & 10: 21 a \\ 11 / 23 / 2003 & 10: 23 a \\ 11 / 23 / 2003 & 10: 23 a\end{array}$




$\begin{array}{llr}11 / 21 / 2003 & 03: 54 \mathrm{p} & 12,671 \text { b8pw3.3i } \\ 11 / 21 / 2003 & 03: 54 \mathrm{p} & 80,206 \text { b8pw3.30 } \\ 11 / 21 / 2003 & 03: 54 \mathrm{p} & 9,523 \text { b8pw3.3p } \\ 11 / 23 / 2003 & 10: 23 \mathrm{a} & 12,674 \text { b8pw35.3i } \\ 11 / 23 / 2003 & 10: 23 \mathrm{a} & 80,953 \text { b8pw35.30 } \\ 11 / 23 / 2003 & 10: 23 \mathrm{a} & 9,526 \text { b8pw35.3p } \\ 11 / 22 / 2003 & 12: 24 \mathrm{p} & 12,672 \text { b8pw4.3i } \\ 11 / 22 / 2003 & 12: 25 \mathrm{p} & 81,833 \text { b8pw4.30 } \\ 11 / 22 / 2003 & 12: 25 \mathrm{p} & 9,524 \text { b8pw4.3p } \\ & 15 \text { File(s) } & 512,050 \text { bytes }\end{array}$

Directory of $D: \backslash$ sensitivity

\begin{tabular}{|c|c|c|}
\hline $01 / 21 / 2004$ & $09: 02 a$ & 41,496 b11b_3.6i \\
\hline $01 / 21 / 2004$ & $09: 14 a$ & $3,480,401$ b11b_3.6o \\
\hline $01 / 21 / 2004$ & $09: 14 a$ & 38,258 b11b_3.6p \\
\hline $01 / 21 / 2004$ & $09: 39 a$ & 346,857 b11b_3.txt \\
\hline $01 / 21 / 2004$ & $09: 14 a$ & 20,691 b11b_3.elem_aqu.txt \\
\hline $01 / 21 / 2004$ & $09: 14 a$ & 18,922 b11b_3.elem_min.txt \\
\hline $01 / 21 / 2004$ & $09: 14 a$ & 18,935 b11b_3.elem_tot.txt \\
\hline $01 / 21 / 2004$ & $09: 14 a$ & 48,840 b11b_3.min_info.txt \\
\hline $12 / 16 / 2003$ & $11: 24 a$ & 12,715 b11pw.3i \\
\hline $12 / 16 / 2003$ & $11: 25 a$ & 78,484 b11pw.30 \\
\hline $12 / 16 / 2003$ & $11: 25 a$ & 9,567 b11pw. 3p \\
\hline $01 / 21 / 2004$ & $09: 25 a$ & 41,284 j13b_3.6i \\
\hline $01 / 21 / 2004$ & $09: 35 a$ & $3,463,274$ j13b_3.6o \\
\hline $01 / 21 / 2004$ & $09: 35 a$ & 38,170 j13b_3.6p \\
\hline $01 / 21 / 2004$ & $09: 39 a$ & 378,061 j13b_3.txt \\
\hline $01 / 21 / 2004$ & $09: 35 a$ & 17.923 j13b_3.elem_tot.txt \\
\hline $01 / 21 / 2004$ & $09: 35 a$ & 19,583 j13b_3.elem_aqu.txt \\
\hline $01 / 21 / 2004$ & $09: 35 a$ & 17,910 j13b_3.elem_min.txt \\
\hline $01 / 21 / 2004$ & $09: 35 a$ & 40,368 j13b_3.min_info.txt \\
\hline $07 / 16 / 2003$ & $10: 54 a$ & 74,420 j13nom 30.30 \\
\hline $07 / 16 / 2003$ & $10: 54 a$ & 9,358 j13nom $30.3 p$ \\
\hline $07 / 16 / 2003$ & $10: 53 a$ & 12,506 j13nom 30i.3i \\
\hline $01 / 21 / 2004$ & $09: 50 a$ & $3,070,976$ sensitivity $\mathrm{xls}$ \\
\hline & 23 File(s) & $11,298,999$ bytes \\
\hline
\end{tabular}


Directory of $\mathrm{D}:$ \water rate

\begin{tabular}{|c|c|c|}
\hline $01 / 27 / 2004$ & $09: 36 a$ & 41,453 b8f3_3.6i \\
\hline $01 / 27 / 2004$ & $09: 54 a$ & $16,109,969$ b8f3_3.60 \\
\hline $01 / 27 / 2004$ & $09: 54 a$ & 38,174 b8 8 3_3.6p \\
\hline $01 / 27 / 2004$ & $09: 54 a$ & 93,265 b8f3_3.elem_aqu.txt \\
\hline $01 / 27 / 2004$ & $09: 54 a$ & 85,208 b8f3_3.elem_min.txt \\
\hline $01 / 27 / 2004$ & $09: 54 a$ & 85,221 b8f3_3.elem_tot.txt \\
\hline $01 / 27 / 2004$ & $09: 54 a$ & 207,368 b8f3_3.min_info.txt \\
\hline $01 / 27 / 2004$ & $10: 41 a$ & 41,453 b8f $4 \_3.6 i$ \\
\hline $01 / 27 / 2004$ & $11: 01 a$ & $16,282,497$ b8f4_3.6o \\
\hline $01 / 27 / 2004$ & $11: 01 a$ & $38,502 b 8 f 4 \_3.6 p$ \\
\hline $01 / 27 / 2004$ & $11: 01 a$ & 84,449 b8f 4 _3.elem_min.txt \\
\hline $01 / 27 / 2004$ & $11: 01 a$ & 92,434 b8f $4 \_3 . e l e m \_a q u . t x t$ \\
\hline $01 / 27 / 2004$ & $11: 01 a$ & 84,462 b8f4_3.elem_tot.txt \\
\hline $01 / 27 / 2004$ & $11: 01 a$ & 197,790 b8f4_3.min_info.txt \\
\hline $01 / 27 / 2004$ & $10: 40 a$ & 41,453 b8f5_3.6i \\
\hline $01 / 27 / 2004$ & $11: 25 a$ & $15,967,440$ b8f5_3.6o \\
\hline $01 / 27 / 2004$ & $11: 25 a$ & 38,420 b8f5_3.6p \\
\hline $01 / 27 / 2004$ & $11: 25 a$ & 83,450 b8f5_3.elem_tot.txt \\
\hline $01 / 27 / 2004$ & $11: 25 a$ & 91,326 b8f5_3.elem_aqu.txt \\
\hline $01 / 27 / 2004$ & $11: 25 a$ & 83,437 b8f5_3.elem_min.txt \\
\hline $01 / 27 / 2004$ & $11: 25 a$ & 180,034 b8f5_3.min_info.txt \\
\hline $01 / 27 / 2004$ & $02: 50 p$ & 379,904 rate comparison.xls \\
\hline & 22 File(s) & $50,347,70$ \\
\hline
\end{tabular}

Directory of $D: \backslash$ heat.zip

04/07/2004 10:58a <DIR> Heat

0 File (s) 0 bytes

Directory of $D: \backslash$ heat.zip $\backslash$ Heat

$\begin{array}{lll}04 / 07 / 2004 & 01: 45 \mathrm{p} & 43,247,1041200 \text { Heat Conduction - Dry TPTPUL.x } 15 \\ 04 / 07 / 2004 & 01: 24 \mathrm{p} & 43,214,84850 \text { at } 1200 \text { Heat Conduction - Dry } \\ \text { TPTPUL.xls } & & 38,245,376 \text { Heat Conduction - Dry TPTPLI.xls } \\ 12 / 15 / 2003 & 03: 18 \mathrm{p} & 38,246,400 \text { Heat Conduction - Dry TPTPLN.xls }\end{array}$




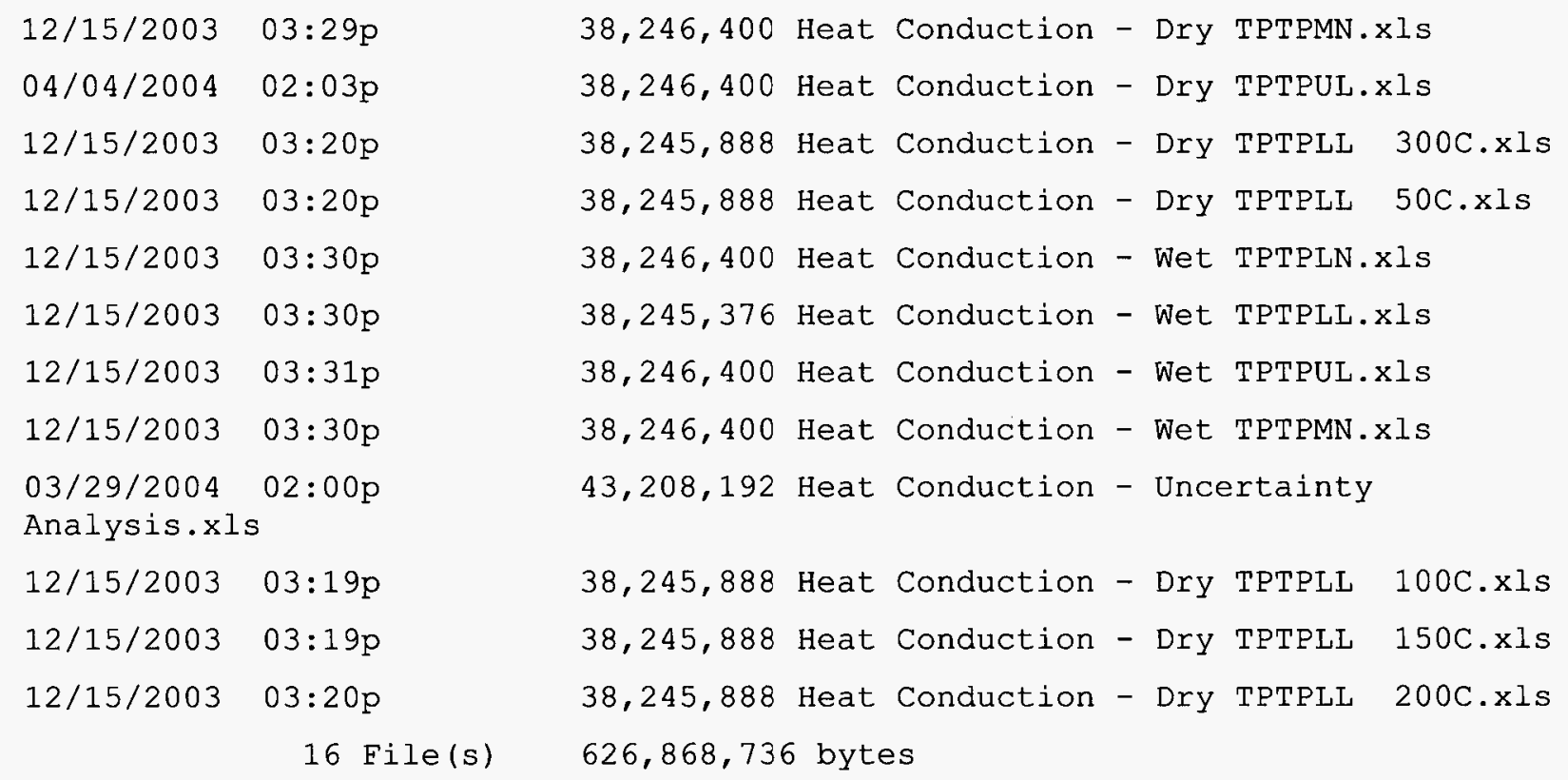

\section{Directory of CD-ROM 2 of 2}

Directory of $D: \backslash$

\begin{tabular}{cccc}
$12 / 16 / 2003$ & $09: 57 a$ & <DIR> & $\mathrm{CO} 2-3$ \\
$01 / 25 / 2004$ & $09: 25 \mathrm{a}$ & <DIR> & $\mathrm{CO} 2-35$ \\
$12 / 10 / 2003$ & $04: 57 \mathrm{p}$ & <DIR> & $\mathrm{CO} 2-4$ \\
\multicolumn{2}{c}{0 File (s) } & 0 bytes
\end{tabular}

Directory of $\mathrm{D}: \backslash \mathrm{CO} 2-3$

\begin{tabular}{|c|c|c|c|}
\hline $01 / 20 / 2004$ & $11: 35 a$ & $\langle\mathrm{DIR}\rangle$ & asprin-3 \\
\hline $12 / 05 / 2003$ & $03: 05 p$ & 41,450 & b8a_3.6i \\
\hline $12 / 05 / 2003$ & $03: 46 p$ & $1,103,545$ & b8a_3.6o \\
\hline $12 / 05 / 2003$ & $03: 46 p$ & 38,172 & b8a_3.6p \\
\hline $12 / 05 / 2003$ & $03: 46 p$ & 7,949 & b8a_3.elem_aqu.txt \\
\hline $12 / 05 / 2003$ & $03: 46 p$ & 7,284 & b8a_3.elem_min.txt \\
\hline $12 / 05 / 2003$ & $03: 46 p$ & 7,297 & b8a_3.elem_tot.txt \\
\hline $12 / 05 / 2003$ & $03: 46 p$ & 17,928 & b8a_3.min_info.txt \\
\hline $12 / 05 / 2003$ & $03: 07 p$ & 41,452 & b8b_3.6i \\
\hline $12 / 05 / 2003$ & $04: 26 p$ & $12,660,648$ & $b 8 b \_3.60$ \\
\hline $12 / 05 / 2003$ & $04: 26 p$ & 38,172 & $b 8 b \_3.6 p$ \\
\hline $12 / 05 / 2003$ & $04: 26 p$ & 55,367 & b8b $3 . e l e m$ tot.txt \\
\hline
\end{tabular}


Igneous Intrusion Impacts on Waste Packages and Waste Forms

\begin{tabular}{|c|c|c|}
\hline $12 / 05 / 2003$ & $04: 26 \mathrm{p}$ & 60,579 b8b_3.elem_aqu.txt \\
\hline $12 / 05 / 2003$ & $04: 26 p$ & 55,354 b8b_3.elem_min.txt \\
\hline $12 / 05 / 2003$ & $04: 26 \mathrm{p}$ & 149,108 b8b_3.min_info.txt \\
\hline $12 / 05 / 2003$ & $03: 11 p$ & 41,452 b8f1_3.6i \\
\hline $12 / 05 / 2003$ & $04: 32 p$ & $4,768,841$ b8 8113.60 \\
\hline $12 / 05 / 2003$ & $04: 32 p$ & 38,254 b8f1_3.6p \\
\hline $12 / 05 / 2003$ & $04: 32 p$ & 26,778 b8f1_3.elem_tot.txt \\
\hline $12 / 05 / 2003$ & $04: 32 p$ & 29,278 b8f1_3.elem_aqu.txt \\
\hline $12 / 05 / 2003$ & $04: 32 p$ & 26,765 b8f1_3.elem_min.txt \\
\hline $12 / 05 / 2003$ & $04: 32 p$ & 67,208 b8f1_3.min_info.txt \\
\hline $12 / 05 / 2003$ & $03: 13 p$ & 41,452 b8f2_3.6i \\
\hline $12 / 05 / 2003$ & $04: 46 p$ & $13,632,565$ b8f2_3.6o \\
\hline $12 / 05 / 2003$ & $04: 46 p$ & $38,336 \mathrm{~b} 8 \mathrm{f} 2{ }_{-} 3.6 \mathrm{p}$ \\
\hline $12 / 05 / 2003$ & $04: 46 p$ & 72,824 b8f2_3.elem_tot.txt \\
\hline $12 / 05 / 2003$ & $04: 46 p$ & 79,692 b8f2_3.elem_aqu.txt \\
\hline $12 / 05 / 2003$ & $04: 46 p$ & 72,811 b8f2_3.elem_min.txt \\
\hline $12 / 05 / 2003$ & $04: 46 p$ & 183,712 b8f2_3.min_info.txt \\
\hline $12 / 05 / 2003$ & $03: 15 p$ & 41,452 b8p_3.6i \\
\hline $12 / 05 / 2003$ & $10: 09 a$ & $6,942,186$ b8p_3.6o \\
\hline $12 / 05 / 2003$ & $10: 09 a$ & 38,254 b8p_3. $6 \mathrm{p}$ \\
\hline $12 / 05 / 2003$ & $10: 08 a$ & 35,095 b8p_3.elem_aqu.txt \\
\hline $12 / 05 / 2003$ & $10: 08 a$ & 32,078 b8p_3.elem_min.txt \\
\hline $12 / 05 / 2003$ & $10: 08 a$ & 32,091 b8p_3.elem_tot.txt \\
\hline $12 / 05 / 2003$ & $10: 08 a$ & 85,812 b8p_3.min_info.txt \\
\hline $12 / 08 / 2003$ & $11: 15 a$ & $38,172 \mathrm{~b} 8 \mathrm{~s} \times 3.6 i$ \\
\hline $12 / 08 / 2003$ & $11: 27 a$ & $2,432,453$ b8s 83.60 \\
\hline $12 / 08 / 2003$ & $11: 27 a$ & $38,172 \mathrm{~b} 8 \mathrm{~s} \times 3.6 \mathrm{p}$ \\
\hline $12 / 08 / 2003$ & $11: 27 a$ & 10,320 b8sx3.elem_min.txt \\
\hline $12 / 08 / 2003$ & $11: 27 a$ & 11,273 b8sx3.elem_aqu.txt \\
\hline $12 / 08 / 2003$ & $11: 27 a$ & $10,333 \mathrm{~b} 8 \mathrm{~s} \times 3$. elem_tot.txt \\
\hline $12 / 08 / 2003$ & $11: 27 a$ & 18,450 b8sx3.min_info.txt \\
\hline $12 / 05 / 2003$ & $03: 17 p$ & 41,452 b8s_3.6i \\
\hline $12 / 05 / 2003$ & $10: 44 \mathrm{a}$ & $13,066,111$ b8s_3.60 \\
\hline $12 / 05 / 2003$ & $10: 44 a$ & 38,172 b8s_3.6p \\
\hline $12 / 05 / 2003$ & $10: 44 a$ & 56,632 b8s_3.elem_tot.txt \\
\hline $12 / 05 / 2003$ & $10: 44 \mathrm{a}$ & 61,964 b8s_3.elem_aqu.txt \\
\hline $12 / 05 / 2003$ & $10: 44 a$ & 56,619 b8s_3.elem_min.txt \\
\hline
\end{tabular}




$$
\begin{array}{cc}
12 / 05 / 2003 \quad 10: 44 a & 152,548 \text { b8s_3.min_info.txt } \\
& 49 \text { File(s) } \quad 56,643,912 \text { bytes }
\end{array}
$$

Directory of $\mathrm{D}: \backslash \mathrm{CO} 2-3 \backslash$ asprin-3

$$
\begin{array}{ll}
01 / 20 / 2004 & 11: 35 a \\
12 / 08 / 2003 & 11: 16 a \\
12 / 08 / 2003 & 11: 17 a \\
12 / 08 / 2003 & 11: 17 a \\
12 / 08 / 2003 & 11: 18 a \\
12 / 08 / 2003 & 11: 19 a \\
12 / 08 / 2003 & 11: 29 a \\
12 / 08 / 2003 & 11: 19 a
\end{array}
$$

\begin{tabular}{|c|c|c|c|}
\hline $03 / 01 / 2004$ & $12: 28 p$ & $\langle\mathrm{DIR}\rangle$ & asprin-35 \\
\hline $12 / 05 / 2003$ & $03: 04 p$ & 41,449 & b8a_35.6i \\
\hline $12 / 05 / 2003$ & $10: 45 a$ & 987,210 & b8a_35.6o \\
\hline $12 / 05 / 2003$ & $10: 45 a$ & 38,256 & $b 8 a \_35.6 p$ \\
\hline $12 / 05 / 2003$ & $10: 45 a$ & 6,538 & b8a_35.elem_tot.txt \\
\hline $12 / 05 / 2003$ & $10: 45 a$ & 7,118 & b8a_35.elem_aqu.txt \\
\hline $1.2 / 05 / 2003$ & $10: 45 a$ & 6,525 & b8a_35.elem_min.txt \\
\hline $12 / 05 / 2003$ & $10: 45 a$ & 15,742 & b8a_35.min_info.txt \\
\hline $01 / 20 / 2004$ & $04: 37 p$ & 38,174 & b8bq35.6i \\
\hline $01 / 20 / 2004$ & $10: 05 a$ & $12,484,547$ & b8bq35. 60 \\
\hline $01 / 20 / 2004$ & $10: 05 a$ & 38,174 & $b 8 b q 35.6 p$ \\
\hline $01 / 20 / 2004$ & $10: 05 a$ & 56,424 & b8bq35.elem_aqu.txt \\
\hline $01 / 20 / 2004$ & $10: 05 a$ & 51,559 & b8bq35.elem_min.txt \\
\hline $01 / 20 / 2004$ & $10: 05 a$ & 51,572 & b8bq35.elem_tot.txt \\
\hline $01 / 20 / 2004$ & $10: 05 a$ & 87,565 & b8bq35.min_info.txt \\
\hline $01 / 20 / 2004$ & $10: 10 a$ & 38,174 & $\mathrm{~b} 8 \mathrm{br} 35.6 i$ \\
\hline $01 / 20 / 2004$ & $10: 39 a$ & $12,514,046$ & $\mathrm{~b} 8 \mathrm{br} 35.60$ \\
\hline $01 / 20 / 2004$ & $10: 39 a$ & 38,174 & $b 8 b r 35.6 p$ \\
\hline $01 / 20 / 2004$ & $10: 39 a$ & 56,701 & b8br35.elem_aqu.txt \\
\hline $01 / 20 / 2004$ & $10: 39 a$ & 51,812 & b8br35.elem_min.txt \\
\hline
\end{tabular}

8 File (s)

$$
\begin{gathered}
50,713,088 \text { abstraction-3.xls } \\
65,264 \text { b8a_3.txt } \\
1,669,951 \text { b8b_3.txt } \\
458,043 \text { b8f1_3.txt } \\
1,443,348 \text { b8f2_3.txt } \\
857,835 \text { b8p_3.txt } \\
329,802 \text { b8sx3.txt } \\
1,741,059 \text { b8s_3.txt } \\
57,278,390 \text { bytes }
\end{gathered}
$$

Directory of $\mathrm{D}: \backslash \mathrm{CO} 2-35$ 


\begin{tabular}{|c|c|c|}
\hline $01 / 20 / 2004$ & $10: 39 a$ & 51,825 b8br35.elem_tot.txt \\
\hline $01 / 20 / 2004$ & $10: 39 a$ & 87,989 b8br35.min_info.txt \\
\hline $03 / 01 / 2004$ & $11: 08 a$ & 38,174 b8bs $35.6 i$ \\
\hline $03 / 01 / 2004$ & $11: 32 a$ & $9,621,286$ b8bs 35.60 \\
\hline $03 / 01 / 2004$ & $11: 32 a$ & $38,256 \mathrm{~b} 8 \mathrm{bs} 35.6 \mathrm{p}$ \\
\hline $03 / 01 / 2004$ & $11: 32 a$ & 43,405 b8bs35.elem_aqu.txt \\
\hline $03 / 01 / 2004$ & $11: 32 a$ & 39,668 b8bs $35 . e l e m \_m i n . t x t$ \\
\hline $03 / 01 / 2004$ & $11: 32 a$ & $39,681 \mathrm{~b} 8 \mathrm{bs} 35$. elem_tot.txt \\
\hline $03 / 01 / 2004$ & $11: 32 a$ & 70,396 b8bs35.min_info.txt \\
\hline $01 / 20 / 2004$ & $09: 28 a$ & $38,174 \mathrm{~b} 8 \mathrm{~b} \times 35.6 \mathrm{i}$ \\
\hline $01 / 20 / 2004$ & $09: 56 a$ & $12,523,029 \mathrm{~b} 8 \mathrm{~b} \times 35.6 \mathrm{o}$ \\
\hline $01 / 20 / 2004$ & $09: 56 a$ & $38,174 \mathrm{~b} 8 \mathrm{~b} \times 35.6 \mathrm{p}$ \\
\hline $01 / 20 / 2004$ & $09: 56 a$ & $56,424 \mathrm{~b} 8 \mathrm{~b} \times 35 . e l e m \_a q u . t x t$ \\
\hline $01 / 20 / 2004$ & $09: 56 a$ & 51,559 b8bx35.elem_min.txt \\
\hline $01 / 20 / 2004$ & $09: 56 a$ & $51,572 \mathrm{~b} 8 \mathrm{~b} \times 35 . \mathrm{elem}$ tot.t.txt \\
\hline $01 / 20 / 2004$ & $09: 56 a$ & 87,565 b8bx35.min_info.txt \\
\hline $01 / 20 / 2004$ & $11: 20 a$ & 38,174 b8by35.6i \\
\hline $01 / 20 / 2004$ & $11: 47 a$ & $12,516,734$ b8by 35.60 \\
\hline $01 / 20 / 2004$ & $11: 47 a$ & 38,174 b8by35.6p \\
\hline $01 / 20 / 2004$ & $11: 47 a$ & 56,424 b8by 35 .elem_aqu.txt \\
\hline $01 / 20 / 2004$ & $11: 47 a$ & 51,559 b8by 35. elem_min.txt \\
\hline $01 / 20 / 2004$ & $11: 47 a$ & 51,572 b8by 35. elem_tot.txt \\
\hline $01 / 20 / 2004$ & $11: 47 a$ & 87,565 b8by $35 . m i n$ info.txt \\
\hline $01 / 20 / 2004$ & $11: 52 \mathrm{a}$ & $38,174 \mathrm{~b} 8 \mathrm{bz} 35.6 \mathrm{i}$ \\
\hline $01 / 20 / 2004$ & $12: 21 \mathrm{p}$ & $12,504,895 \mathrm{~b} 8 \mathrm{bz} 35.6 \mathrm{o}$ \\
\hline $01 / 20 / 2004$ & $12: 21 p$ & 38,174 b8bz35.6p \\
\hline $01 / 20 / 2004$ & $12: 21 \mathrm{p}$ & 56,424 b8bz35.elem_aqu.txt \\
\hline $01 / 20 / 2004$ & $12: 21 p$ & 51,559 b8bz35.elem_min.txt \\
\hline $01 / 20 / 2004$ & $12: 21 \mathrm{p}$ & $51,572 \mathrm{~b} 8 \mathrm{bz} 35$. elem_tot.txt \\
\hline $01 / 20 / 2004$ & $12: 21 p$ & 87,565 b8bz35.min_info.txt \\
\hline $01 / 20 / 2004$ & $08: 58 a$ & 41,294 b8b_35.6i \\
\hline $01 / 20 / 2004$ & $09: 11 \mathrm{a}$ & $4,782,264$ b8b_35.6o \\
\hline $01 / 20 / 2004$ & $09: 11 a$ & 38,174 b8b_35.6p \\
\hline $01 / 20 / 2004$ & $09: 11 a$ & 24,569 b8b_35.elem_aqu.txt \\
\hline $01 / 20 / 2004$ & $09: 11 a$ & 22,464 b8b_35.elem_min.txt \\
\hline $01 / 20 / 2004$ & $09: 11 a$ & 22,477 b8b_35.elem_tot.txt \\
\hline $01 / 20 / 2004$ & $09: 11 a$ & 56,283 b8b_35.min_info.txt \\
\hline
\end{tabular}




\begin{tabular}{|c|c|c|c|}
\hline $12 / 05 / 2003$ & $03: 11 p$ & 41,449 & $b 8 f 1 \_35.6 i$ \\
\hline $12 / 05 / 2003$ & $11: 24 a$ & $4,634,878$ & $\mathrm{~b} 8 \mathrm{f} 1{ }_{-} 35.60$ \\
\hline $12 / 05 / 2003$ & $11: 24 a$ & 38,256 & $\mathrm{~b} 8 \mathrm{f} 1 \_35.6 p$ \\
\hline $12 / 05 / 2003$ & $11: 24 a$ & 25,766 & b8f1_35.elem_tot.txt \\
\hline $12 / 05 / 2003$ & $11: 24 a$ & 28,170 & b8f1_35.elem_aqu.txt \\
\hline $12 / 05 / 2003$ & $11: 24 a$ & 25,753 & b8f1_35.elem_min.txt \\
\hline $12 / 05 / 2003$ & $11: 24 a$ & 62,558 & b8f1_35.min_info.txt \\
\hline $12 / 05 / 2003$ & $03: 13 p$ & 41,449 & $\mathrm{~b} 8 \mathrm{f} 2{ }^{3} 35.6 i$ \\
\hline $12 / 05 / 2003$ & $11: 38 a$ & $13,432,671$ & $b 8 f 2 \_35.60$ \\
\hline $12 / 05 / 2003$ & $11: 38 a$ & 38,174 & $b 8 f 2 \_35.6 p$ \\
\hline $12 / 05 / 2003$ & $11: 38 a$ & 71,812 & b8f2_35.elem_tot.txt \\
\hline $12 / 05 / 2003$ & $11: 38 a$ & 78,584 & b8f2_35.elem_aqu.txt \\
\hline $12 / 05 / 2003$ & $11: 38 a$ & 71,799 & b8f2_35.elem_min.txt \\
\hline $12 / 05 / 2003$ & $11: 38 a$ & 168,188 & b8f2_35.min_info.txt \\
\hline $12 / 10 / 2003$ & $03: 05 p$ & 38,174 & b8pq35.6i \\
\hline $12 / 10 / 2003$ & $03: 33 p$ & $12,520,661$ & b8pq35.6o \\
\hline $12 / 10 / 2003$ & $03: 33 p$ & 38,174 & b8pq35.6p \\
\hline $12 / 10 / 2003$ & $03: 33 p$ & 56,424 & b8pq35.elem_aqu.txt \\
\hline $12 / 10 / 2003$ & $03: 33 p$ & 51,559 & b8pq35.elem_min.txt \\
\hline $12 / 10 / 2003$ & $03: 33 p$ & 51,572 & b8pq35.elem_tot.txt \\
\hline $12 / 10 / 2003$ & $03: 33 p$ & 87,562 & b8pq35.min_info.txt \\
\hline $12 / 10 / 2003$ & $04: 12 p$ & 38,174 & b8pr35.6i \\
\hline $12 / 10 / 2003$ & $04: 38 p$ & $12,532,839$ & b8pr35.60 \\
\hline $12 / 10 / 2003$ & $04: 38 p$ & 38,174 & $b 8 p r 35.6 p$ \\
\hline $12 / 10 / 2003$ & $04: 38 p$ & 56,701 & b8pr35.elem_aqu.txt \\
\hline $12 / 10 / 2003$ & $04: 38 p$ & 51,812 & b8pr35.elem_min.txt \\
\hline $12 / 10 / 2003$ & $04: 38 p$ & 51,825 & b8pr35.elem_tot.txt \\
\hline $12 / 10 / 2003$ & $04: 38 p$ & 87,986 & b8pr35.min_info.txt \\
\hline $12 / 09 / 2003$ & $01: 53 p$ & 38,174 & $b 8 p \times 35.6 i$ \\
\hline $12 / 09 / 2003$ & $02: 54 p$ & $12,498,549$ & $\mathrm{~b} 8 \mathrm{p} \times 35.60$ \\
\hline $12 / 09 / 2003$ & $02: 54 p$ & 38,174 & $b 8 p \times 35.6 p$ \\
\hline $12 / 09 / 2003$ & $02: 54 \mathrm{p}$ & 56,147 & b8px35.elem_aqu.txt \\
\hline $12 / 09 / 2003$ & $02: 54 \mathrm{p}$ & 51,306 & b8px35.elem_min.txt \\
\hline $12 / 09 / 2003$ & $02: 54 p$ & 51,319 & b8px35.elem_tot.txt \\
\hline $12 / 09 / 2003$ & $02: 54 p$ & 87,138 & b8px35.min_info.txt \\
\hline $12 / 10 / 2003$ & $09: 14 a$ & 38,174 & b8py35.6i \\
\hline $12 / 10 / 2003$ & $10: 13 a$ & $12,504,211$ & b8py35.6o \\
\hline
\end{tabular}




\begin{tabular}{|c|c|c|}
\hline $12 / 10 / 2003$ & $10: 13 a$ & 38,174 b8py35.6p \\
\hline $12 / 10 / 2003$ & $10: 13 a$ & 56,147 b8py35.elem_aqu.txt \\
\hline $12 / 10 / 2003$ & $10: 13 a$ & 51,306 b8py35.elem_min.txt \\
\hline $12 / 10 / 2003$ & $10: 13 a$ & 51,319 b8py35.elem_tot.txt \\
\hline $12 / 10 / 2003$ & $10: 13 a$ & 87,138 b8py35.min_info.txt \\
\hline $12 / 10 / 2003$ & $11: 35 a$ & 38,174 b8pz35.6i \\
\hline $12 / 10 / 2003$ & $12: 03 p$ & $12,524,530 \mathrm{~b} 8 \mathrm{pz} 35.60$ \\
\hline $12 / 10 / 2003$ & $12: 03 p$ & 38,174 b8pz35.6p \\
\hline $12 / 10 / 2003$ & $12: 02 p$ & 56,424 b8pz35.elem_aqu.txt \\
\hline $12 / 10 / 2003$ & $12: 02 p$ & 51,559 b8pz35.elem_min.txt \\
\hline $12 / 10 / 2003$ & $12: 02 p$ & 51,572 b8pz35.elem_tot.txt \\
\hline $12 / 10 / 2003$ & $12: 02 p$ & 87,562 b8pz35.min_info.txt \\
\hline $12 / 08 / 2003$ & $11: 39 a$ & 41,449 b8p_35.6i \\
\hline $12 / 08 / 2003$ & $12: 02 p$ & $4,780,999$ b8p_35.6o \\
\hline $12 / 08 / 2003$ & $12: 02 p$ & 38,174 b8p_35.6p \\
\hline $12 / 08 / 2003$ & $12: 02 p$ & 24,569 b8p_35.elem_aqu.txt \\
\hline $12 / 08 / 2003$ & $12: 02 p$ & 22,464 b8p_35.elem_min.txt \\
\hline $12 / 08 / 2003$ & $12: 02 p$ & 22,477 b8p_35.elem_tot.txt \\
\hline $12 / 08 / 2003$ & $12: 02 p$ & 56,280 b8p_35.min_info.txt \\
\hline $01 / 20 / 2004$ & $01: 20 p$ & $38,174 \mathrm{~b} 8 \mathrm{sq} 35.6 \mathrm{i}$ \\
\hline $01 / 20 / 2004$ & $01: 50 p$ & $10,580,460 \mathrm{~b} 8 \mathrm{sq} 35.60$ \\
\hline $01 / 20 / 2004$ & $01: 50 p$ & $38,256 \mathrm{~b} 8 \mathrm{sq} 35.6 \mathrm{p}$ \\
\hline $01 / 20 / 2004$ & $01: 50 p$ & 47,837 b8sq35.elem_aqu.txt \\
\hline $01 / 20 / 2004$ & $01: 50 p$ & 43,716 b8sq35.elem_min.txt \\
\hline $01 / 20 / 2004$ & $01: 50 p$ & 43,729 b8sq35.elem_tot.txt \\
\hline $01 / 20 / 2004$ & $01: 50 p$ & 75,071 b8sq35.min_info.txt \\
\hline $01 / 20 / 2004$ & $09: 29 a$ & $38,174 \mathrm{~b} 8 \mathrm{~s} \times 35.6 \mathrm{i}$ \\
\hline $01 / 20 / 2004$ & $10: 25 a$ & $12,472,609 \mathrm{~b} 8 \mathrm{~s} \times 35.60$ \\
\hline $01 / 20 / 2004$ & $10: 25 a$ & $38,174 \mathrm{~b} 8 \mathrm{~s} \times 35.6 \mathrm{p}$ \\
\hline $01 / 20 / 2004$ & $10: 25 a$ & 56,147 b8sx35.elem_aqu.txt \\
\hline $01 / 20 / 2004$ & $10: 25 a$ & 51,306 b8sx35.elem_min.txt \\
\hline $01 / 20 / 2004$ & $10: 25 a$ & 51,319 b8sx35.elem_tot.txt \\
\hline $01 / 20 / 2004$ & $10: 25 a$ & 87,141 b8sx35.min_info.txt \\
\hline $01 / 20 / 2004$ & $10: 47 a$ & 38,174 b8sy35.6i \\
\hline $01 / 20 / 2004$ & $11: 15 a$ & $12,469,812$ b8sy35.6o \\
\hline $01 / 20 / 2004$ & $11: 15 a$ & 38,174 b8sy35.6p \\
\hline $01 / 20 / 2004$ & $11: 15 a$ & 51,306 b8sy35.elem_min.txt \\
\hline
\end{tabular}




\begin{tabular}{|c|c|c|}
\hline $01 / 20 / 2004$ & $11: 15 a$ & 56,147 b8sy35.elem_aqu.txt \\
\hline $01 / 20 / 2004$ & $11: 15 a$ & 51,319 b8sy35.elem_tot.txt \\
\hline $01 / 20 / 2004$ & $11: 15 a$ & 87,141 b8sy35.min_info.txt \\
\hline $01 / 20 / 2004$ & $11: 53 a$ & 38,174 b8sz35.6i \\
\hline $01 / 20 / 2004$ & $12: 51 p$ & $12,453,342$ b8sz 35.60 \\
\hline $01 / 20 / 2004$ & $12: 51 p$ & 38,174 b8sz35.6p \\
\hline $01 / 20 / 2004$ & $12: 51 p$ & 56,147 b8sz35.elem_aqu.txt \\
\hline $01 / 20 / 2004$ & $12: 51 p$ & 51,306 b8sz35.elem_min.txt \\
\hline $01 / 20 / 2004$ & $12: 51 p$ & 51,319 b8sz35.elem_tot.txt \\
\hline $01 / 20 / 2004$ & $12: 51 p$ & 87,141 b8sz35.min_info.txt \\
\hline $01 / 20 / 2004$ & $08: 58 \mathrm{a}$ & 41,295 b8s_35.6i \\
\hline $01 / 20 / 2004$ & $09: 22 a$ & $4,821,987$ b8s_35.60 \\
\hline $01 / 20 / 2004$ & $09: 22 a$ & 38,174 b8s_35.6p \\
\hline $01 / 20 / 2004$ & $09: 22 a$ & 24,846 b8s_35.elem_aqu.txt \\
\hline $01 / 20 / 2004$ & $09: 22 a$ & 22,717 b8s_35.elem_min.txt \\
\hline $01 / 20 / 2004$ & $09: 22 a$ & 22,730 b8s_35.elem_tot.txt \\
\hline $01 / 20 / 2004$ & $09: 22 a$ & 56,899 b8s_35.min_info.txt \\
\hline & 147 File (s) & $222,344,291$ bytes \\
\hline
\end{tabular}

Directory of $\mathrm{D}: \backslash \mathrm{CO} 2-35 \backslash$ asprin-35

\begin{tabular}{|c|c|c|c|}
\hline $03 / 01 / 2004$ & $12: 28 p$ & $29,227,008$ & abstraction $-35 . \times 1 s$ \\
\hline $12 / 10 / 2003$ & $04: 58 p$ & 59,061 & $b 8 a \_35 . t x t$ \\
\hline $01 / 21 / 2004$ & $03: 57 p$ & $1,741,062$ & b8bq35.txt \\
\hline $01 / 21 / 2004$ & $03: 59 p$ & $1,741,062$ & b8br35.txt \\
\hline $03 / 01 / 2004$ & $12: 03 p$ & $1,335,004$ & b8bs $35 . t x t$ \\
\hline $01 / 21 / 2004$ & $03: 53 p$ & $1,741,062$ & $\mathrm{~b} 8 \mathrm{~b} \times 35 . \mathrm{txt}$ \\
\hline $01 / 21 / 2004$ & $03: 56 p$ & $1,741,062$ & b8by35.txt \\
\hline $01 / 21 / 2004$ & $03: 56 p$ & $1,741,062$ & $\mathrm{~b} 8 \mathrm{~b} z 35 . \mathrm{txt}$ \\
\hline $01 / 21 / 2004$ & $03: 53 p$ & 581,062 & b8b_35.txt \\
\hline $12 / 10 / 2003$ & $10: 12 a$ & 457,524 & b8f1_35.txt \\
\hline $12 / 10 / 2003$ & $10: 18 a$ & $1,449,789$ & b8f2_35.txt \\
\hline $12 / 10 / 2003$ & $10: 22 a$ & $1,741,062$ & b8pq35.txt \\
\hline $12 / 10 / 2003$ & $10: 23 a$ & $1,741,062$ & b8pr35.txt \\
\hline $12 / 10 / 2003$ & $10: 20 a$ & $1,741,062$ & b8px35.txt \\
\hline $12 / 10 / 2003$ & $10: 21 a$ & $1,741,062$ & b8py35.txt \\
\hline $12 / 10 / 2003$ & $10: 21 a$ & $1,741,062$ & b8pz35.txt \\
\hline
\end{tabular}




$\begin{array}{llr}12 / 10 / 2003 & 10: 19 \mathrm{a} & 581,062 \mathrm{~b} 8 \mathrm{p} \_35 . \mathrm{txt} \\ 01 / 21 / 2004 & 04: 18 \mathrm{p} & 1,471,478 \mathrm{~b} 8 \mathrm{sq} 35 . \mathrm{txt} \\ 01 / 21 / 2004 & 04: 15 \mathrm{p} & 1,741,062 \mathrm{~b} 8 \mathrm{~s} \times 35 . \mathrm{txt} \\ 01 / 21 / 2004 & 04: 16 \mathrm{p} & 1,741,062 \mathrm{~b} 8 \mathrm{sy} 35 . \mathrm{txt} \\ 01 / 21 / 2004 & 04: 17 \mathrm{p} & 1,741,062 \mathrm{~b} 8 \mathrm{sz3} 35 . \mathrm{txt} \\ 01 / 21 / 2004 & 04: 14 \mathrm{p} & 581,062 \mathrm{~b} 8 \mathrm{~s} 355 . \mathrm{txt} \\ & 22 \text { File(s) } & 58,376,856 \text { bytes }\end{array}$

Directory of $\mathrm{D}: \backslash \mathrm{CO} 2-4$

\begin{tabular}{|c|c|c|c|}
\hline $01 / 27 / 2004$ & $11: 31 a$ & $<$ DIR $>$ & asprin-4 \\
\hline $12 / 05 / 2003$ & $03: 06 p$ & 41,449 & b8a_4.6i \\
\hline $12 / 05 / 2003$ & $12: 43 p$ & 961,316 & b8a_4.6o \\
\hline $12 / 05 / 2003$ & $12: 43 p$ & 38,172 & $b 8 a_{-} 4.6 p$ \\
\hline $12 / 05 / 2003$ & $12: 43 p$ & 6,538 & b8a_4.elem_tot.txt \\
\hline $12 / 05 / 2003$ & $12: 43 p$ & 7,118 & $\mathrm{~b} 8 \mathrm{a} \_4 . e l e m \_a q u \cdot t \times t$ \\
\hline $12 / 05 / 2003$ & $12: 43 p$ & 6,525 & $\mathrm{~b} 8 \mathrm{a} \_4 . e l e m \_m i n . t x t$ \\
\hline $12 / 05 / 2003$ & $12: 43 p$ & 15,742 & b8a_4.min_info.txt \\
\hline $12 / 10 / 2003$ & $11: 35 a$ & 38,172 & $\mathrm{~b} 8 \mathrm{bq} 4.6 \mathrm{i}$ \\
\hline $12 / 10 / 2003$ & $01: 04 p$ & $12,603,955$ & $\mathrm{~b} 8 \mathrm{bq} 4.60$ \\
\hline $12 / 10 / 2003$ & $01: 04 p$ & 38,254 & $\mathrm{~b} 8 \mathrm{bq} 4.6 \mathrm{p}$ \\
\hline $12 / 10 / 2003$ & $01: 04 \mathrm{p}$ & 56,701 & $\mathrm{~b} 8 \mathrm{bq} 4 . e l e m_{-} a q u \cdot t \times t$ \\
\hline $12 / 10 / 2003$ & $01: 04 p$ & 51,812 & b8bq4.elem_min.txt \\
\hline $12 / 10 / 2003$ & $01: 04 p$ & 51,825 & $\mathrm{~b} 8 \mathrm{bq} 4 . e 1 e m \_t o t . t x t$ \\
\hline $12 / 10 / 2003$ & $01: 04 p$ & 91,420 & $\mathrm{~b} 8 \mathrm{bq} 4 . \mathrm{min}$ _info.txt \\
\hline $12 / 10 / 2003$ & $01: 34 p$ & 38,254 & $b 8 b \times 4.6 i$ \\
\hline $12 / 10 / 2003$ & $02: 13 p$ & $5,174,632$ & $\mathrm{~b} 8 \mathrm{br} 4.60$ \\
\hline $12 / 10 / 2003$ & $02: 13 p$ & 38,254 & $b 8 b r 4.6 p$ \\
\hline $12 / 10 / 2003$ & $02: 13 p$ & 23,461 & $\mathrm{~b} 8 \mathrm{br} 4 . \mathrm{elem}$ aqu.txt \\
\hline $12 / 10 / 2003$ & $02: 13 p$ & 21,452 & b8br4.elem_min.txt \\
\hline $12 / 10 / 2003$ & $02: 13 p$ & 21,465 & b8br4.elem_tot.txt \\
\hline $12 / 10 / 2003$ & $02: 13 p$ & 39,148 & b8br4.min_info.txt \\
\hline $12 / 08 / 2003$ & $02: 02 p$ & 38,254 & $\mathrm{~b} 8 \mathrm{~b} \times 4.6 \mathrm{i}$ \\
\hline $12 / 08 / 2003$ & $03: 31 p$ & $12,542,025$ & $\mathrm{~b} 8 \mathrm{~b} \times 4.60$ \\
\hline $12 / 08 / 2003$ & $03: 31 p$ & 38,172 & $\mathrm{~b} 8 \mathrm{~b} \times 4.6 \mathrm{p}$ \\
\hline $12 / 08 / 2003$ & $03: 31 p$ & 56,424 & b8bx4.elem_aqu.txt \\
\hline $12 / 08 / 2003$ & $03: 31 p$ & 51,559 & b8bx4.elem_min.txt \\
\hline
\end{tabular}




\begin{tabular}{|c|c|c|}
\hline $12 / 08 / 2003$ & $03: 31 p$ & 51,572 b8bx4.elem_tot.txt \\
\hline $12 / 08 / 2003$ & $03: 31 p$ & 92,460 b8bx $4 . m i n$ info.txt \\
\hline $12 / 08 / 2003$ & $10: 01 a$ & 38,172 b8by $4.6 i$ \\
\hline $12 / 08 / 2003$ & $11: 07 a$ & $12,539,215$ b8by 4.60 \\
\hline $12 / 08 / 2003$ & $11: 07 a$ & 38,172 b8by $4.6 p$ \\
\hline $12 / 08 / 2003$ & $11: 07 a$ & 56,424 b8by $4 . e l e m \_a q u . t x t$ \\
\hline $12 / 08 / 2003$ & $11: 07 a$ & 51,559 b8by 4. elem_min.txt \\
\hline $12 / 08 / 2003$ & $11: 07 a$ & 51,572 b8by $4 . e 1$ em_tot.txt \\
\hline $12 / 08 / 2003$ & $11: 07 a$ & 87,562 b8by $4 . m i n \_$info.txt \\
\hline $12 / 09 / 2003$ & $10: 36 a$ & $38,172 \mathrm{~b} 8 \mathrm{bz} 4.6 \mathrm{i}$ \\
\hline $12 / 09 / 2003$ & $12: 05 p$ & $12,548,076 \mathrm{~b} 8 \mathrm{bz} 4.60$ \\
\hline $12 / 09 / 2003$ & $12: 05 p$ & 38,172 b8bz $4.6 p$ \\
\hline $12 / 09 / 2003$ & $12: 05 p$ & 56,424 b8bz 4 .elem_aqu.txt \\
\hline $12 / 09 / 2003$ & $12: 05 p$ & 51,559 b8bz4.elem_min.txt \\
\hline $12 / 09 / 2003$ & $12: 05 p$ & 51,572 b8bz4.elem_tot.txt \\
\hline $12 / 09 / 2003$ & $12: 05 p$ & 87,562 b8bz $4 . m i n \_i n f o . t x t$ \\
\hline $12 / 08 / 2003$ & $11: 39 a$ & 41,451 b8b_4.6i \\
\hline $12 / 08 / 2003$ & $12: 26 p$ & $4,668,965$ b8b_4.60 \\
\hline $12 / 08 / 2003$ & $12: 26 p$ & 38,254 b8b_4. $6 \mathrm{p}$ \\
\hline $12 / 08 / 2003$ & $12: 26 p$ & 23,184 b8b_4.elem_aqu.txt \\
\hline $12 / 08 / 2003$ & $12: 26 p$ & 21,199 b8b_4.elem_min.txt \\
\hline $12 / 08 / 2003$ & $12: 26 \mathrm{p}$ & 21,212 b8b_4.elem_tot.txt \\
\hline $12 / 08 / 2003$ & $12: 26 \mathrm{p}$ & 53,008 b8b_4.min_info.txt \\
\hline $11 / 22 / 2003$ & $12: 58 p$ & 41,450 b8d_4.6i \\
\hline $12 / 09 / 2003$ & $01: 56 p$ & $38,172 \mathrm{~b} 8 \mathrm{flq} 4.6 \mathrm{i}$ \\
\hline $12 / 09 / 2003$ & $03: 59 p$ & $8,536,982$ b8f $1 \mathrm{q} 4.60$ \\
\hline $12 / 09 / 2003$ & $03: 59 p$ & $38,172 b 8 f 1 q 4.6 p$ \\
\hline $12 / 09 / 2003$ & $03: 59 p$ & 39,250 b8f1q4.elem_aqu.txt \\
\hline $12 / 09 / 2003$ & $03: 59 p$ & 35,873 b8f1q4.elem_min.txt \\
\hline $12 / 09 / 2003$ & $03: 59 p$ & 35,886 b8flq4.elem_tot.txt \\
\hline $12 / 09 / 2003$ & $03: 59 p$ & 61,274 b8flq4.min_info.txt \\
\hline $12 / 08 / 2003$ & $02: 03 p$ & 38,172 b $8 f 1 \times 4.6 i$ \\
\hline $12 / 08 / 2003$ & $04: 04 p$ & $12,613,772$ b8 $81 \times 4.60$ \\
\hline $12 / 08 / 2003$ & $04: 04 \mathrm{p}$ & $38,172 b 8 \pm 1 \times 4.6 p$ \\
\hline $12 / 08 / 2003$ & $04: 03 p$ & 57,809 b8f $1 \times 4$. elem_aqu.txt \\
\hline $12 / 08 / 2003$ & $04: 03 p$ & 52,824 b8f $1 \times 4$.elem_min.txt \\
\hline $12 / 08 / 2003$ & $04: 03 p$ & 52,837 b8f $1 \times 4$.elem_tot.txt \\
\hline
\end{tabular}




\begin{tabular}{|c|c|c|}
\hline $12 / 08 / 2003$ & $04: 04 p$ & 89,682 b8f $1 \times 4 . m i n$ info.txt \\
\hline $12 / 08 / 2003$ & $10: 03 a$ & 38,172 b $8 f 1 y 4.6 i$ \\
\hline $12 / 08 / 2003$ & $11: 41 a$ & $12,559,800$ b8f $1 y 4.60$ \\
\hline $12 / 08 / 2003$ & $11: 41 a$ & $38,172 \mathrm{~b} 8 \mathrm{f} 1 \mathrm{y} 4.6 \mathrm{p}$ \\
\hline $12 / 08 / 2003$ & $11: 40 a$ & 57,255 b8f1y4.elem_aqu.txt \\
\hline $12 / 08 / 2003$ & $11: 40 a$ & 52,318 b8f1y4.elem_min.txt \\
\hline $12 / 08 / 2003$ & $11: 40 a$ & 52,331 b8f $1 y^{4}$.elem_tot.txt \\
\hline $12 / 08 / 2003$ & $11: 41 \mathrm{a}$ & 88,834 b8f1y4.min_info.txt \\
\hline $12 / 09 / 2003$ & $08: 56 a$ & 38,172 b8f1z4.6i \\
\hline $12 / 09 / 2003$ & $10: 44 a$ & $12,670,010$ b8 $81 z 4.60$ \\
\hline $12 / 09 / 2003$ & $10: 44 \mathrm{a}$ & 38,172 b8f $1 \mathrm{z} 4.6 \mathrm{p}$ \\
\hline $12 / 09 / 2003$ & $10: 44 a$ & 58,363 b8f $1 z 4 . e l e m \_a q u . t x t$ \\
\hline $12 / 09 / 2003$ & $10: 44 a$ & 53,330 b8f1z4.elem_min.txt \\
\hline $12 / 09 / 2003$ & $10: 44 a$ & $53,343 \mathrm{~b} 8 \mathrm{f} 1 \mathrm{z} 4$. elem_tot.txt \\
\hline $12 / 09 / 2003$ & $10: 44 a$ & 90,530 b8flz4.min_info.txt \\
\hline $12 / 08 / 2003$ & $11: 39 a$ & 41,451 b8f1_4.6i \\
\hline $12 / 08 / 2003$ & $12: 38 p$ & $5,102,125$ b8f1_4.6o \\
\hline $12 / 08 / 2003$ & $12: 38 p$ & 38,172 b8f1_4.6p \\
\hline $12 / 08 / 2003$ & $12: 37 p$ & 27,893 b8f1_4.elem_aqu.txt \\
\hline $12 / 08 / 2003$ & $12: 37 p$ & 25,500 b8f1_4.elem_min.txt \\
\hline $12 / 08 / 2003$ & $12: 37 p$ & 25,513 b8f1_4.elem_tot.txt \\
\hline $12 / 08 / 2003$ & $12: 37 p$ & 61,942 b8f1_4.min_info.txt \\
\hline $12 / 05 / 2003$ & $03: 14 p$ & 41,451 b8f $2 \_4.6 i$ \\
\hline $12 / 05 / 2003$ & $02: 13 p$ & $13,408,358$ b8f $2 \_4.60$ \\
\hline $12 / 05 / 2003$ & $02: 13 p$ & 38,172 b8f $2 \_4.6 p$ \\
\hline $12 / 05 / 2003$ & $02: 12 \mathrm{p}$ & 71,812 b8f2_4.elem_tot.txt \\
\hline $12 / 05 / 2003$ & $02: 12 p$ & 78,584 b8f2_4.elem_aqu.txt \\
\hline $12 / 05 / 2003$ & $02: 12 p$ & 71,799 b8f2_4.elem_min.txt \\
\hline $12 / 05 / 2003$ & $02: 12 p$ & 168,188 b8f2_4.min_info.txt \\
\hline $12 / 09 / 2003$ & $04: 24 p$ & $38,172 \mathrm{~b} 8 \mathrm{pq} 4.6 \mathrm{i}$ \\
\hline $12 / 09 / 2003$ & $10: 51 a$ & $12,403,722 \mathrm{~b} 8 \mathrm{pq} 4.60$ \\
\hline $12 / 09 / 2003$ & $10: 51 a$ & $38,254 \mathrm{~b} 8 \mathrm{pq} 4.6 \mathrm{p}$ \\
\hline $12 / 09 / 2003$ & $10: 51 a$ & 55,870 b8pq4.elem_aqu.txt \\
\hline $12 / 09 / 2003$ & $10: 51 a$ & 51,053 b8pq4.elem_min.txt \\
\hline $12 / 09 / 2003$ & $10: 51 a$ & 51,066 b8pq4.elem_tot.txt \\
\hline $12 / 09 / 2003$ & $10: 51 a$ & 91,300 b8pq4.min_info.txt \\
\hline $12 / 08 / 2003$ & $02: 06 p$ & $38,172 \mathrm{~b} 8 \mathrm{px} 4.6 \mathrm{i}$ \\
\hline
\end{tabular}




\begin{tabular}{|c|c|c|c|}
\hline $12 / 08 / 2003$ & $04: 33 p$ & $12,537,460$ & $\mathrm{~b} 8 \mathrm{p} \times 4.60$ \\
\hline $12 / 08 / 2003$ & $04: 33 p$ & 38,172 & $\mathrm{~b} 8 \mathrm{p} \times 4.6 \mathrm{p}$ \\
\hline $12 / 08 / 2003$ & $04: 33 p$ & 56,424 & b8px4.elem_aqu.txt \\
\hline $12 / 08 / 2003$ & $04: 33 p$ & 51,559 & b8px4.elem_min.txt \\
\hline $12 / 08 / 2003$ & $04: 33 p$ & 51,572 & b8px4.elem_tot.txt \\
\hline $12 / 08 / 2003$ & $04: 33 p$ & 87,562 & b8px4.min_info.txt \\
\hline $12 / 08 / 2003$ & $10: 05 a$ & 38,172 & b8py4.6i \\
\hline $12 / 08 / 2003$ & $12: 11 p$ & $12,557,370$ & b8py 4.60 \\
\hline $12 / 08 / 2003$ & $12: 11 p$ & 38,172 & b8py $4.6 p$ \\
\hline $12 / 08 / 2003$ & $12: 11 p$ & 56,701 & b8py4.elem_aqu.txt \\
\hline $12 / 08 / 2003$ & $12: 11 \mathrm{p}$ & 51,812 & b8py4.elem_min.txt \\
\hline $12 / 08 / 2003$ & $12: 11 p$ & 51,825 & b8py4.elem_tot.txt \\
\hline $12 / 08 / 2003$ & $12: 11 \mathrm{p}$ & 87,986 & b8py4.min_info.txt \\
\hline $12 / 09 / 2003$ & $08: 57 a$ & 38,172 & b8pz4.6i \\
\hline $12 / 09 / 2003$ & $11: 14 \mathrm{a}$ & $12,574,906$ & b8pz4.6o \\
\hline $12 / 09 / 2003$ & $11: 14 a$ & 38,172 & $b 8 p z 4.6 p$ \\
\hline $12 / 09 / 2003$ & $11: 14 \mathrm{a}$ & 56,701 & b8pz4.elem_aqu.txt \\
\hline $12 / 09 / 2003$ & $11: 14 a$ & 51,812 & b8pz4.elem_min.txt \\
\hline $12 / 09 / 2003$ & $11: 14 a$ & 51,825 & b8pz4.elem_tot.txt \\
\hline $12 / 09 / 2003$ & $11: 14 a$ & 87,986 & b8pz4.min_info.txt \\
\hline $12 / 08 / 2003$ & $11: 39 a$ & 41,451 & $b 8 p \_4.6 i$ \\
\hline $12 / 08 / 2003$ & $12: 51 \mathrm{p}$ & $4,698,092$ & $b 8 p-4.60$ \\
\hline $12 / 08 / 2003$ & $12: 51 p$ & 38,172 & $b 8 p_{-} 4.6 p$ \\
\hline $12 / 08 / 2003$ & $12: 51 p$ & 23,461 & b8p_4.elem_aqu.txt \\
\hline $12 / 08 / 2003$ & $12: 51 \mathrm{p}$ & 21,452 & b8p_4.elem_min.txt \\
\hline $12 / 08 / 2003$ & $12: 51 \mathrm{p}$ & 21,465 & b8p_4.elem_tot.txt \\
\hline $12 / 08 / 2003$ & $12: 51 \mathrm{p}$ & 53,672 & b8p_4.min_info.txt \\
\hline $12 / 08 / 2003$ & $02: 07 p$ & 38,254 & $b 8 s \times 4.6 i$ \\
\hline $12 / 08 / 2003$ & $04: 55 p$ & $9,292,188$ & $\mathrm{~b} 8 \mathrm{~s} \times 4.60$ \\
\hline $12 / 08 / 2003$ & $04: 55 p$ & 38,254 & $b 8 s \times 4.6 p$ \\
\hline $12 / 08 / 2003$ & $04: 55 p$ & 37,644 & b8sx4.elem_min.txt \\
\hline $12 / 08 / 2003$ & $04: 55 p$ & 41,189 & b8sx4.elem_aqu.txt \\
\hline $12 / 08 / 2003$ & $04: 55 p$ & 37,657 & b8s $84 . e l e m \_t o t . t x t$ \\
\hline $12 / 08 / 2003$ & $04: 55 p$ & 67,820 & b8sx4.min_info.txt \\
\hline $12 / 08 / 2003$ & $11: 39 a$ & 41,451 & $b 8 s \_4.6 i$ \\
\hline $12 / 08 / 2003$ & $01: 05 p$ & $4,669,230$ & b8s_4. 60 \\
\hline $12 / 08 / 2003$ & $01: 05 p$ & 38,254 & $b 8 s \_4.6 p$ \\
\hline
\end{tabular}




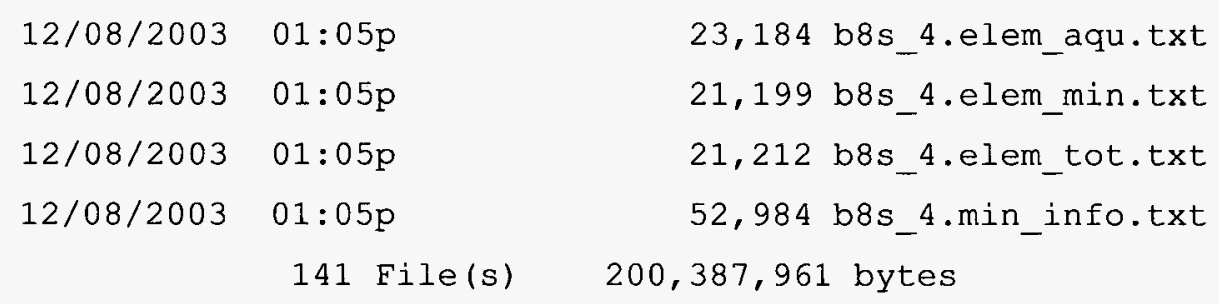

Directory of $\mathrm{D}: \backslash \mathrm{CO} 2-4 \backslash$ asprin-4

\begin{tabular}{|c|c|c|}
\hline $01 / 27 / 2004$ & $11: 31 a$ & $56,294,400$ abstraction-4.xls \\
\hline $12 / 10 / 2003$ & $04: 58 p$ & 53,431 b8a_4.txt \\
\hline $12 / 10 / 2003$ & $10: 06 a$ & $1,741,059 \mathrm{~b} 8 \mathrm{bq} 4 . \mathrm{txt}$ \\
\hline $12 / 10 / 2003$ & $10: 06 a$ & 705,759 b8br $4 . t x t$ \\
\hline $12 / 10 / 2003$ & $10: 00 a$ & $1,741,059 \mathrm{~b} 8 \mathrm{bx} 4 . \mathrm{txt}$ \\
\hline $12 / 10 / 2003$ & $10: 01 a$ & $1,741,059$ b8by4.txt \\
\hline $12 / 10 / 2003$ & $10: 05 a$ & $1,741,059 \mathrm{~b} 8 \mathrm{bz} 4 . \mathrm{txt}$ \\
\hline $12 / 10 / 2003$ & $04: 59 p$ & 581,059 b8b_4.txt \\
\hline $12 / 10 / 2003$ & $10: 16 a$ & $1,173,706 \mathrm{~b} 8 \mathrm{fl} 1 \mathrm{q} 4 . \mathrm{txt}$ \\
\hline $12 / 10 / 2003$ & $10: 14 a$ & $1,741,062$ b $8 \mathrm{f} 1 \times 4 . t x t$ \\
\hline $12 / 10 / 2003$ & $10: 14 a$ & $1,741,062$ b8f1y4.txt \\
\hline $12 / 10 / 2003$ & $10: 15 a$ & $1,741,062$ b8f1z4.txt \\
\hline $12 / 10 / 2003$ & $10: 13 a$ & 581,062 b8f1_4.txt \\
\hline $12 / 10 / 2003$ & $10: 17 a$ & $1,451,236$ b8f2_4.txt \\
\hline $12 / 10 / 2003$ & $10: 23 a$ & $1,708,579 \mathrm{~b} 8 \mathrm{pq} 4 . \mathrm{txt}$ \\
\hline $12 / 10 / 2003$ & $10: 25 a$ & $1,741,059$ b8px4.txt \\
\hline $12 / 10 / 2003$ & $10: 24 a$ & $1,741,059$ b8py $4 . t x t$ \\
\hline $12 / 10 / 2003$ & $10: 24 a$ & $1,741,059$ b8pz4.txt \\
\hline $12 / 10 / 2003$ & $10: 26 a$ & 581,059 b8p_4.txt \\
\hline $12 / 10 / 2003$ & $10: 28 a$ & $1,262,501$ b8sx4.txt \\
\hline $12 / 10 / 2003$ & $10: 27 a$ & 581,059 b8s_4.txt \\
\hline & 21 File (s) & $82,384,450$ bytes \\
\hline
\end{tabular}




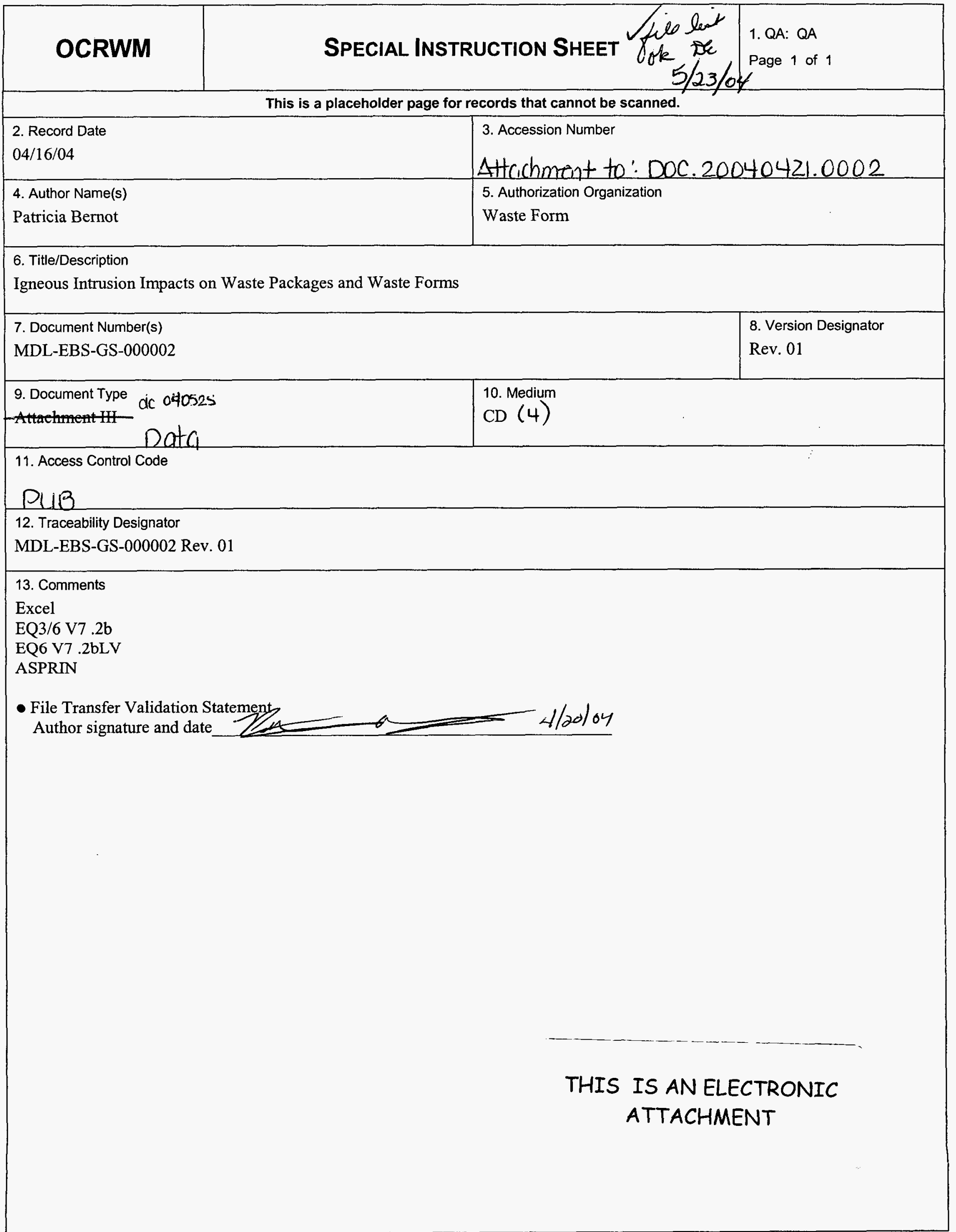




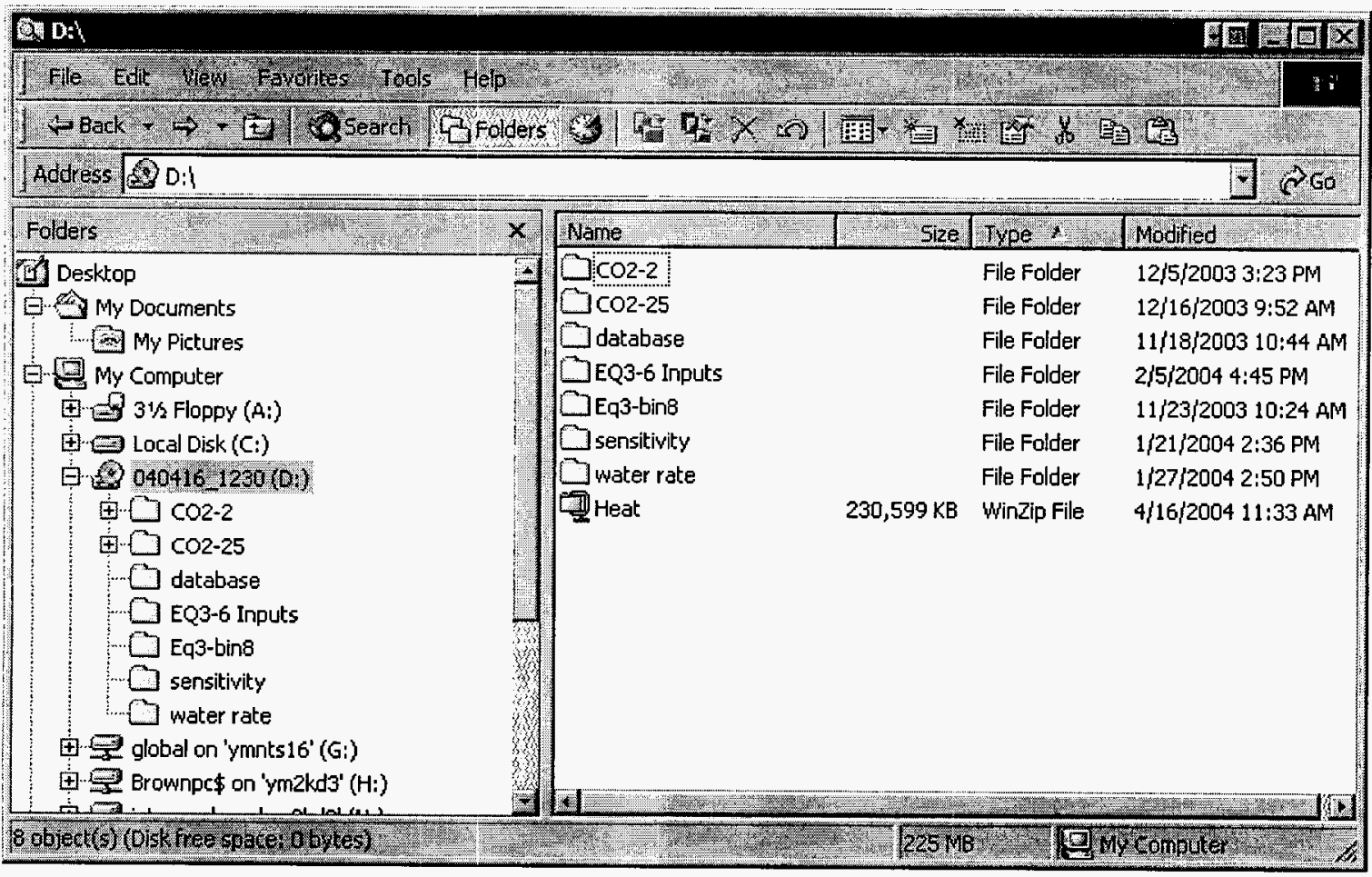




\begin{tabular}{|c|c|c|c|c|c|}
\hline $3 \mathrm{DA}, \mathrm{COZ}-2$ & & 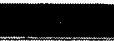 & 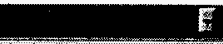 & 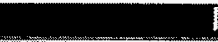 & $\mathrm{DE} \mathrm{E}$ \\
\hline 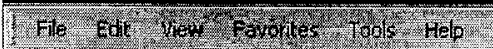 & 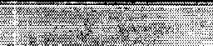 & Fir? & 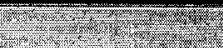 & (207) & (2) \\
\hline 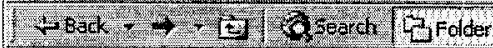 & 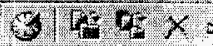 & $y=x+y$ & 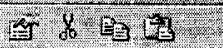 & T.8. & 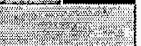 \\
\hline 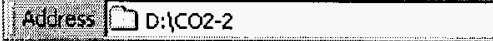 & & & & & $\gamma_{60}$ \\
\hline folders & Yame 2,3 & 3.0 & Type & Modfled. & (3) \\
\hline (1) Desktop & Jasprin-2 & & File Folder & 1/20/2004 11:32 AM & \\
\hline$\theta 8$ My Documents & as b8a_2.6i & $41 \mathrm{~KB}$ & 6I File & 12/5/2003 10:49 AM & \\
\hline My Pictures & بb8a_2.6o & $933 \mathrm{~KB}$ & 60 File & 12/5/2003 11:05 AM & \\
\hline$\Theta$ My Computer & $b 8 a \_2.6 p$ & $38 \mathrm{~KB}$ & 6P File & 12/5/2003 11:05 AM & \\
\hline$\oplus \equiv 3 \%$ Floppy (Ai) & Ejba_z.elem_aqu & $7 \mathrm{~KB}$ & Text Document & 12/5/2003 11:05 AM & \\
\hline$\bigoplus$ Local Disk (C:) & 쿨 b8a_2.elem_min & $7 \mathrm{~KB}$ & Text Document & 12/5/2003 11:05 AM & \\
\hline$\boxminus 040416 \_1230$ (D:) & E bBa_2.elem_tot & $7 \mathrm{~KB}$ & Text Document & 12/5/2003 11:05 AM & \\
\hline$\oplus 0 \mathrm{CO2}$ & EbBa_2.min_info & $14 \mathrm{~KB}$ & Text Document & 12/5/2003 11:05 AM & \\
\hline 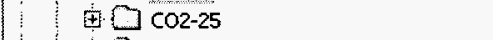 & [andbob_2.6i & $41 \mathrm{~KB}$ & 6 I File & $12 / 5 / 2003$ 10:49 AM & 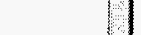 \\
\hline database & inb8b_2.6o & $10,714 \mathrm{~KB}$ & $60 \mathrm{Flle}$ & 12/5/2003 11:43 AM & \\
\hline EQ3-6 Inputs & [a] $68 \mathrm{~b} \_2.6 \mathrm{p}$ & $38 \mathrm{~KB}$ & 6P File & 12/5/2003 11:43 AM & 13 \\
\hline Eq3-bin8 & bob_2.elem_aqu & $52 \mathrm{~KB}$ & Text Document & $12 / 5 / 200311: 43 \mathrm{AM}$ & ma \\
\hline sensitivity & Esb_2.elem_min & $48 \mathrm{~KB}$ & Text Document & 12/5/2003 11:43 AM & \\
\hline water rate & ] b8b_2.elem_tot & $48 \mathrm{~KB}$ & Text Document & $12 / 5 / 200311: 43$ AM & $\therefore$ \\
\hline global an 'ymnts16' (G:) & Ebob_2.min_info & $113 \mathrm{~KB}$ & Text Document & 12/5/2003 11:43 AM & 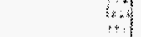 \\
\hline$\Phi$ Brownpc $\$$ on 'ym2kd3' ( $\left.\mathrm{H}_{i}\right)$ & E $b 8 f 1 \_2.6 i$ & $41 \mathrm{~KB}$ & 6I File & $12 / 5 / 2003$ 10:58 AM & 7 \\
\hline † intra-web on 'ymzkd2' (N:) & gesf1_2.60 & $4,536 \mathrm{~KB}$ & 60 File & $12 / 5 / 200311: 49$ AM & in \\
\hline the group on 'ymzkd2' $(0:)$ & abof1_2.6p & $38 \mathrm{~KB}$ & 6P File & $12 / 5 / 200311: 49 \mathrm{AM}$ & 1 \\
\hline$\oplus$ data on 'ym2kd2' (Q:) & E b8f1_2.elem_aqu & $29 \mathrm{~KB}$ & Text Document & 12/5/2003 11:49 AM & ) \\
\hline 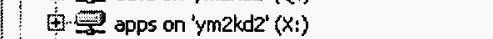 & 들 b8f1_2.elem_min & $26 \mathrm{~KB}$ & Text Document & $12 / 5 / 200311: 49$ AM & \\
\hline (4) Control Panel & Es b8f1_2.elem_tot & $26 \mathrm{~KB}$ & Text Document & $12 / 5 / 200311: 49$ AM & 4 \\
\hline † My Network Places & E] b8f1_2.min_info & $57 \mathrm{~KB}$ & Text Document & $12 / 5 / 200311: 49 \mathrm{AM}$ & i: \\
\hline Recycle Bin & $68 f 222.6 i$ & $41 \mathrm{~KB}$ & 6I File & 12/5/2003 10:57 AM & il \\
\hline \& Internet Explorer & Bb8f2_2.60 & $12,882 \mathrm{~KB}$ & 60 File & 12/5/2003 12:02 PM & \\
\hline & $968 f 222.6 p$ & $37 \mathrm{~KB}$ & 6P File & 12/5/2003 12:02 PM & tis \\
\hline
\end{tabular}




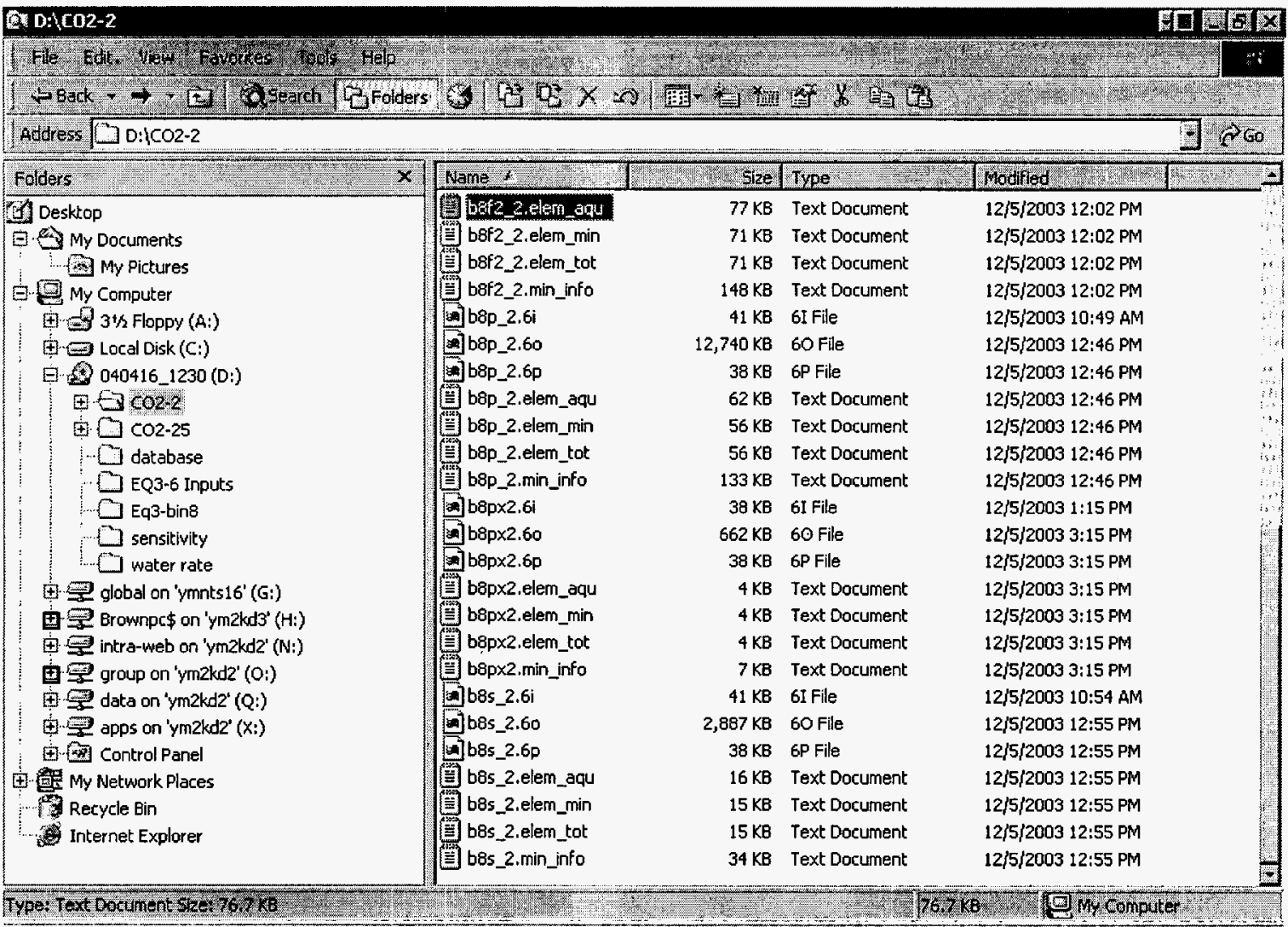




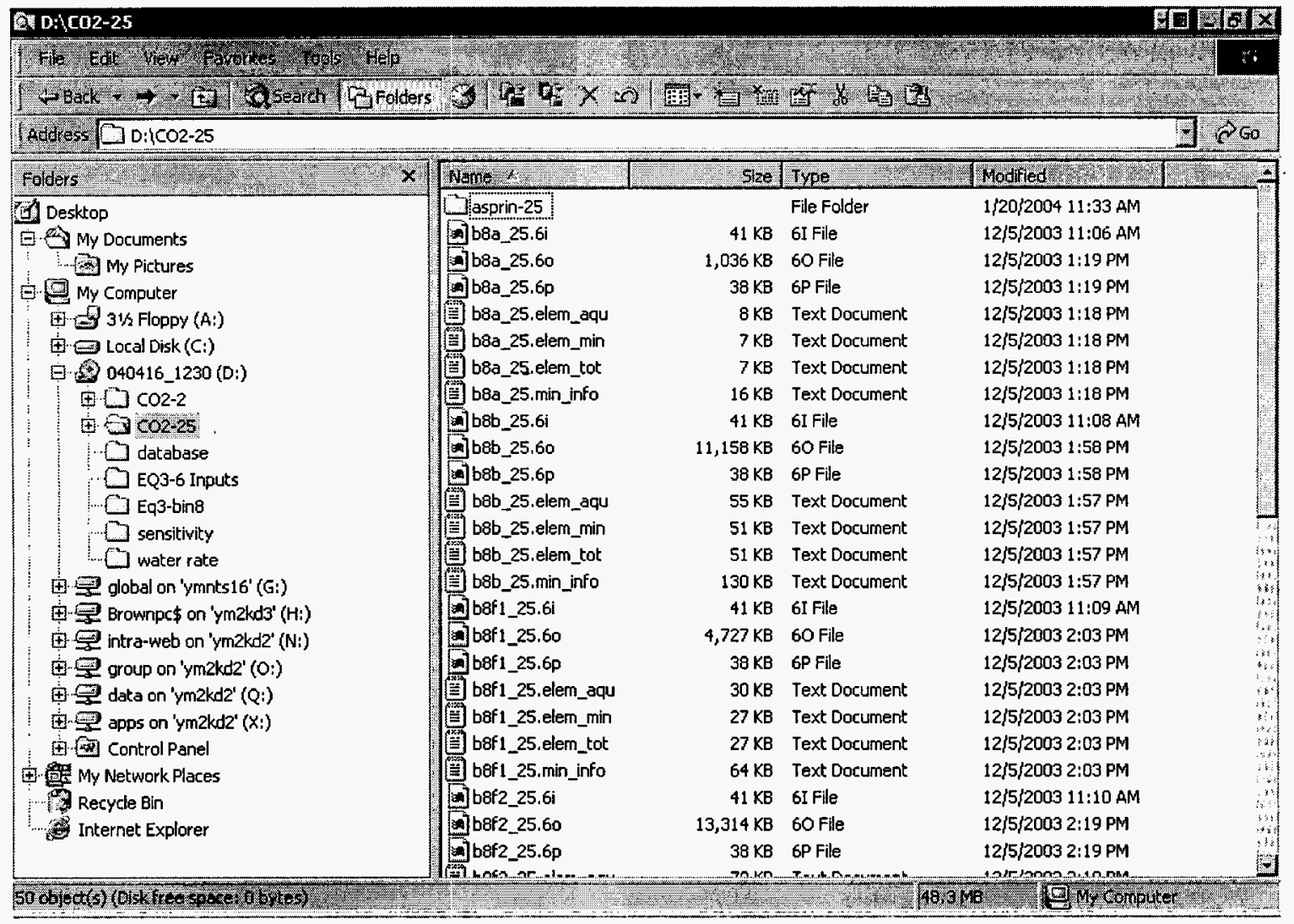




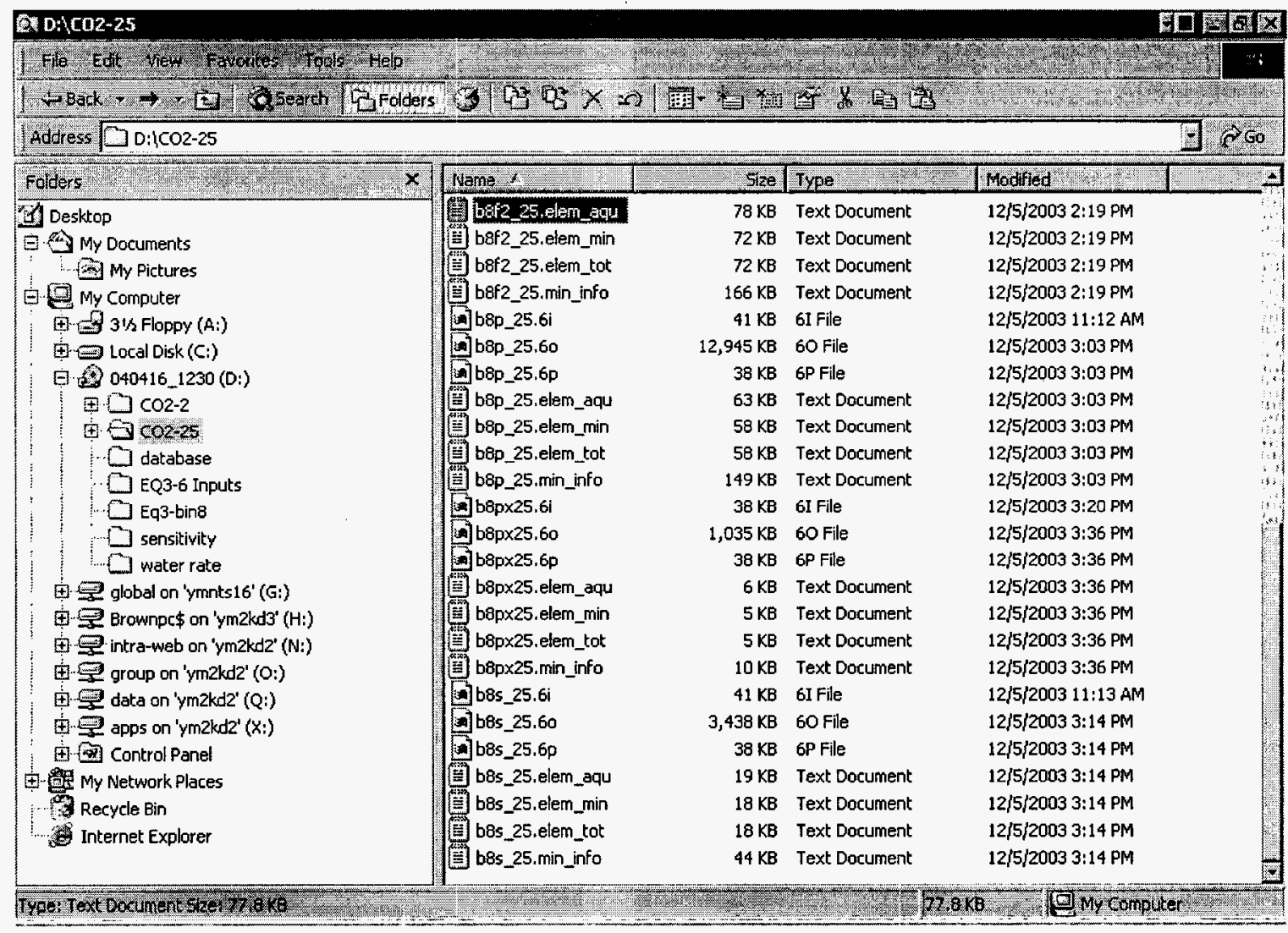




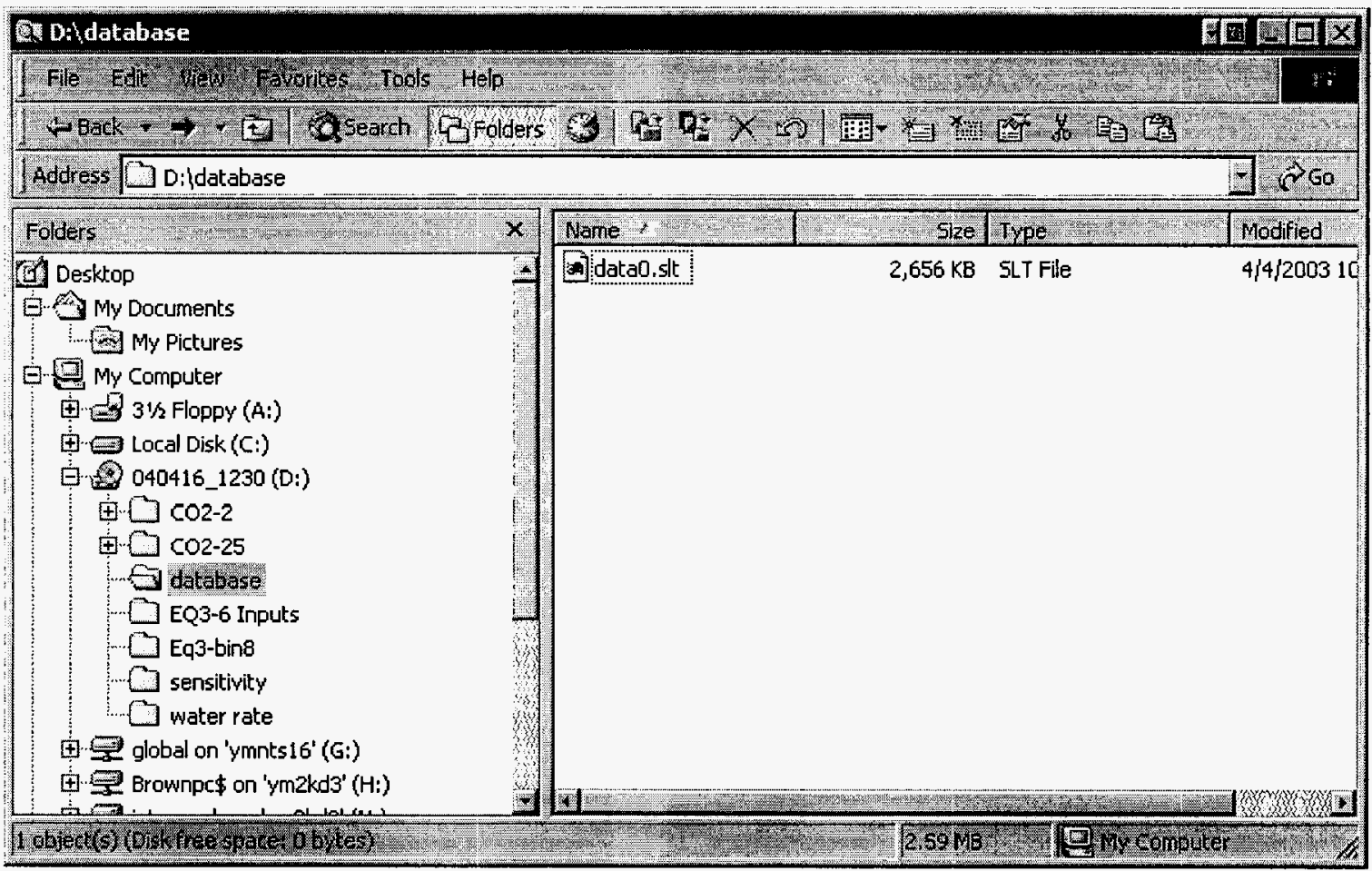




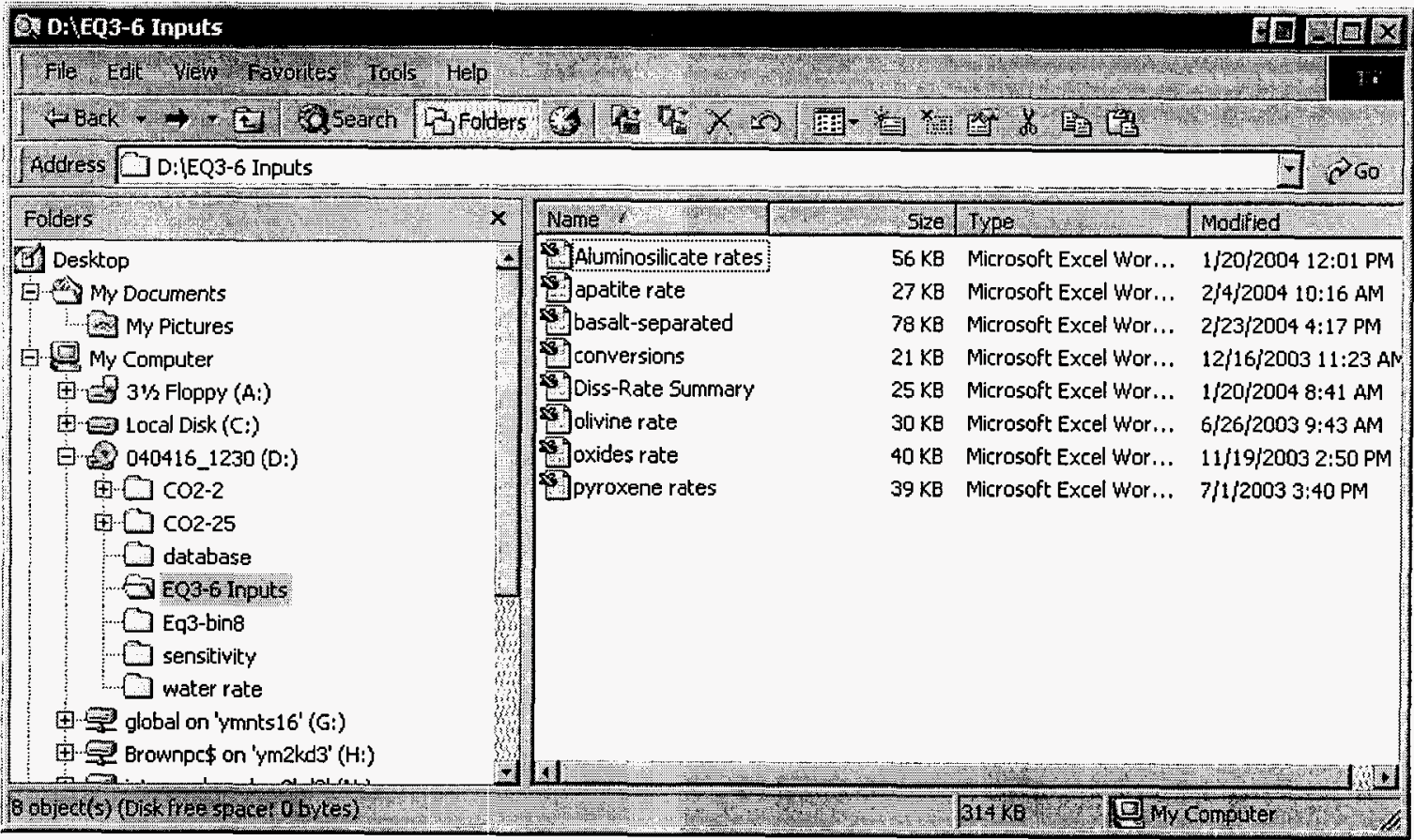




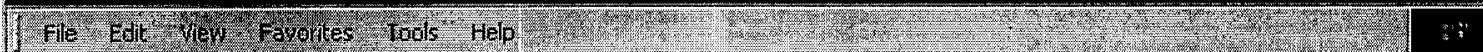

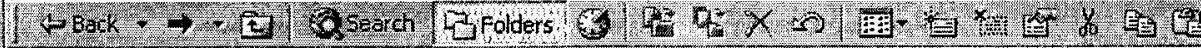
Bddress $\mathrm{D}$ :'íq3-bin8 1 cे 60

\begin{tabular}{|c|c|c|c|c|c|}
\hline W. & $\mathrm{x}$ & Name $1 /$. & \begin{tabular}{|l|l|} 
& Stze \\
\end{tabular} & Type & Modified in \\
\hline DI Desktop & $\Delta$ & (2) $68 \mathrm{pw2}$ & $13 \mathrm{~KB}$ & 3I File & $11 / 22 / 200312: 23 \mathrm{PN}$ \\
\hline$B$ By Documents & 7 & [ 68 pw2 & $77 \mathrm{~KB}$ & 30 File & $11 / 22 / 200312: 24 \mathrm{PM}$ \\
\hline My Pictures & I & b8pw2 & $10 \mathrm{~KB}$ & 3P File & $11 / 22 / 200312: 24 \mathrm{PM}$ \\
\hline My Computer & 19 & [9] b8pw25 & $13 \mathrm{~KB}$ & 3I File & $11 / 23 / 200310: 21 \mathrm{AN}$ \\
\hline$\exists 31 / 2$ Floppy (A:) & 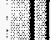 & [E] b8pw25 & $78 \mathrm{~KB}$ & 30 File & $11 / 23 / 200310: 23 \mathrm{AN}$ \\
\hline Local Disk (C:) & M & b8pw25 & $10 \mathrm{~KB}$ & 3P File & $11 / 23 / 200310: 23 \mathrm{AR}$ \\
\hline @2040416_1230(D:) & M & 区eppw3 & $13 \mathrm{~KB}$ & 3l File & $11 / 21 / 20033: 54 \mathrm{PM}$ \\
\hline$\Phi \cos ^{2} 2$ & m & [5]bow3 & $79 \mathrm{~KB}$ & 30 File & 11/21/2003 3:54 PM \\
\hline $00 \mathrm{CO}-25$ & 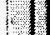 & [E] b8pw3 & $10 \mathrm{~KB}$ & 3 P File & $11 / 21 / 20033: 54 \mathrm{PM}$ \\
\hline 0 database & 1 & 9] b8pw35 & $13 \mathrm{~KB}$ & 3I File & $11 / 23 / 200310: 23 \mathrm{AN}$ \\
\hline$\square$ EQ3-6 Inputs & 1 & b8pw35 & $80 \mathrm{~KB}$ & 30 File & $11 / 23 / 200310: 23 \mathrm{AN}$ \\
\hline Genetins & m & E b8pw35 & $10 \mathrm{~KB}$ & 3P File & 11/23/2003 10:23 AM \\
\hline sensitivity & m & 9 b8pw4 & $13 \mathrm{~KB}$ & 3I File & $11 / 22 / 200312: 24 \mathrm{PN}$ \\
\hline$\square$ water rate & m & Gbopw4 & $80 \mathrm{~KB}$ & 30 File & $11 / 22 / 200312: 25 \mathrm{PN}$ \\
\hline 审 3 global on 'ymnts 16' (G:) & m & b8pw4 & $10 \mathrm{~KB}$ & 3P File & $11 / 22 / 200312: 25 \mathrm{PV}$ \\
\hline 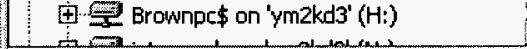 & ] & $M$ & & & ror $\quad$ mind \\
\hline
\end{tabular}


OY Disensitivity

MD陼而

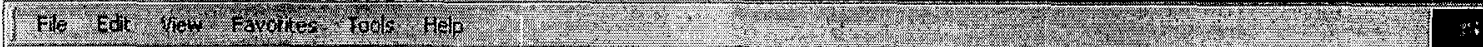

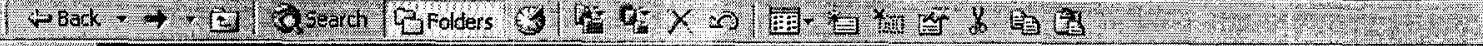
Taddress Ca D:|sensitivity

\begin{tabular}{|c|c|c|c|c|}
\hline Folders & Narre 2 & 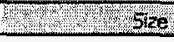 & Type & Modified \\
\hline Desktop & $0 \mathrm{~b} 11 \mathrm{~b} 3.6 \mathrm{i}$ & $41 \mathrm{~KB}$ & 6I File & $1 / 21 / 20049: 02$ AM \\
\hline 8 My Documents & [a] bl1b_3.60 & $3,399 \mathrm{~KB}$ & 60 File & $1 / 21 / 20049: 14$ AM \\
\hline : My Pictures & indib_3.6p & $38 \mathrm{~KB}$ & 6P File & 1/21/2004 9:14 AM \\
\hline 10 My Computer & (플 bl1b_3.elem_aqu & $21 \mathrm{kB}$ & Text Document & 1/21/2004 9:14 AM \\
\hline$\$ 3^{1 / 2}$ Floppy (A:) & 9 b11b_3.elem_min & $19 \mathrm{~KB}$ & Text Dacument & $1 / 21 / 20049: 14 \mathrm{AM}$ \\
\hline$\Phi$ Lacal Disk $\left(C_{i}\right)$ & (3) b11b_3.elem_tot & $19 \mathrm{~KB}$ & Text Document & $1 / 21 / 20049: 14$ AM \\
\hline -9040416_1230(0:) & 舆 bl1b_3.min_info & $48 \mathrm{~KB}$ & Text Document & 1/21/2004 9:14 AM \\
\hline$\Phi\left[\operatorname{co}^{-2} 2\right.$ & 䇥bl1b_3 & $339 \mathrm{~KB}$ & Text Document & $1 / 21 / 20049: 39 \mathrm{AM}$ \\
\hline 甲. & Qb11pw & $13 \mathrm{~KB}$ & 3I File & $12 / 16 / 200311: 24 \mathrm{AM}$ \\
\hline database & bilpw & $77 \mathrm{~KB}$ & 30 File & $12 / 16 / 200311: 25 \mathrm{AM}$ \\
\hline EQ3-6 Inputs & (E) b11 pus & $10 \mathrm{~KB}$ & 3P File & $12 / 16 / 200311: 25 \mathrm{AM}$ \\
\hline$Q_{\text {Eq3-bin } 8}$ & ]13b_3.6i & $41 \mathrm{~KB}$ & 61 File & 1/21/2004 9:25 AM \\
\hline Senstivily & 国j13b_3.60 & $3,383 \mathrm{~KB}$ & 60 File & 1/21/2004 9:35 AM \\
\hline in water rate & 19b_3.6p & $38 \mathrm{~KB}$ & 6P File & 1/21/2004 9:35 AM \\
\hline$\Phi$ global on 'ymnts16' (G:) & 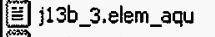 & $20 \mathrm{~KB}$ & Text Document & 1/21/2004 9:35 AM \\
\hline 由 3 Brownpe $\$$ on 'ym2kd3' ( $\mathrm{H}:)$ & 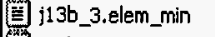 & $18 \mathrm{~KB}$ & Text Document & 1/21/2004 9:35 AM \\
\hline$\oplus 9$ intra-web on 'ym2kd2' (N:) & E j13b_3.elem_tot & $18 \mathrm{~KB}$ & Text Document & 1/21/2004 9:35 AM \\
\hline$\$ \Omega$ group on 'ymzkd2' (O:) & E] j13b_3.min_info & $40 \mathrm{~KB}$ & Text Document & 1/21/2004 9:35 AM \\
\hline (⿶) data on 'ymzkd2' (Q:) & jist_3 & $370 \mathrm{~KB}$ & Text Document & $1 / 21 / 20049: 39$ AM \\
\hline 93 apps on 'ymzkd2' ( $\left.x_{i}\right)$ & [] j13nam30 & $73 \mathrm{~KB}$ & 30 File & $7 / 16,2003$ 10:54 AM \\
\hline HO Control Panel & E j13nom30 & $10 \mathrm{~KB}$ & 3P File & $7 / 16,2003$ 10:54 AM \\
\hline 4 My Network Places & jis j3om30i & $13 \mathrm{~KB}$ & 3I File & $7 / 16 / 2003$ 10:53 AM \\
\hline Recycle Bin & Psensitivity & $2,999 \mathrm{~KB}$ & Microsoft Excel wor... & 1/21/2004 9:50 AM \\
\hline \& Internet Explorer & & & & \\
\hline
\end{tabular}




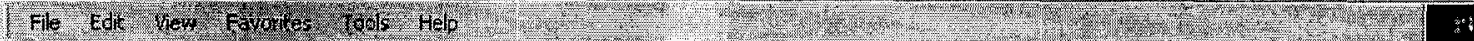

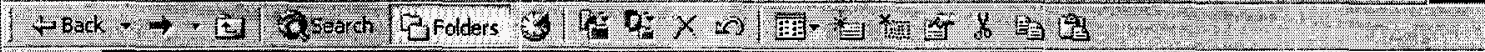
Address $\mathrm{D}$ : iwater rate

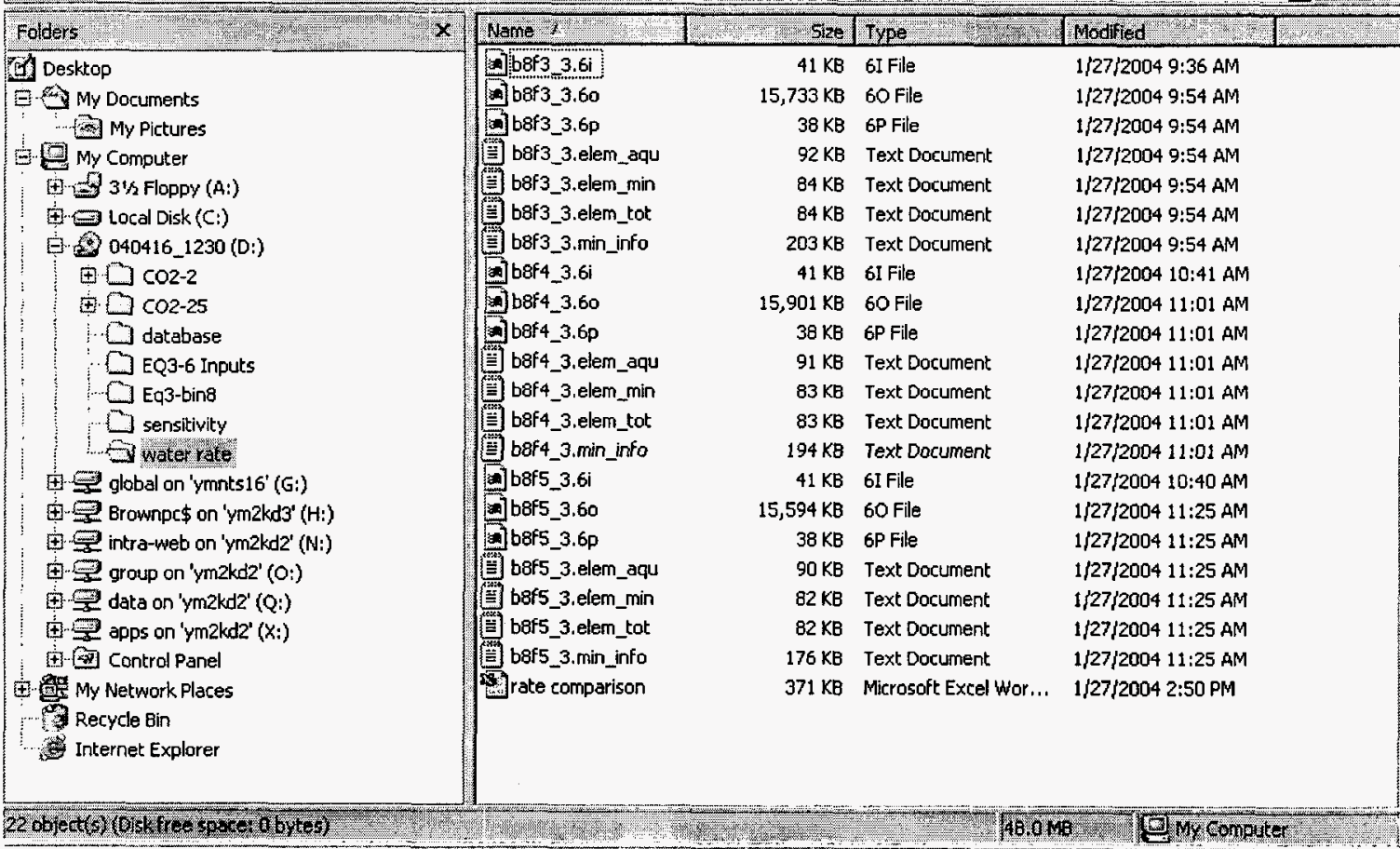




\begin{tabular}{|c|c|c|c|c|c|}
\hline Name & Modified & Size & Ratio & Packed & Path \\
\hline 1200 Heat Conduction - Dry T.. & 4/7/2004 1:45 PM & $43,247,104$ & $62 \%$ & 16,293, & \\
\hline 50 at 1200 Heat Conduction...- & 4/7/2004 1:24 PM & $43,214,848$ & $63 \%$ & $16,182,125$ & \\
\hline Heat Conduction - Dry TPTPL. & 12/15/2003 3:19 PM & $38,245,888$ & $63 \%$ & $14,328,120$ & t) \\
\hline Heat Conduction - Dry TPTPL... & 12/15/2003 3:19 PM & $38,245,888$ & $63 \%$ & $14,150,476$ & \\
\hline Heat Conduction - Dry TPTPL & 12/15/2003 3:20 PM & $38,245,888$ & $63 \%$ & $14,128,632$ & \\
\hline Heat Conduction - Dry TPTPL. & 12/15/2003 3:20 PM & $38,245,888$ & $64 \%$ & $13,910,452$ & \\
\hline Heat Conduction - Dry TPTPL.. & 12/15/2003 3:20 PM & $38,245,888$ & $62 \%$ & $14,473,570$ & \\
\hline Heat Conduction - Dry TPTPL.. & 12/15/2003 3:18 PM & $38,245,376$ & $62 \%$ & $14,583,471$ & \\
\hline Heat Conduction - Dry TPTPL.. & 12/15/2003 3:21 PM & $38,246,400$ & $62 \%$ & 7,942 & \\
\hline Heat Conduction - Dry TPTP... & 12/15/2003 3:29 PM & $38,246,400$ & $62 \%$ & $14,584,973$ & \\
\hline Heat Conduction - Dry TPTP. & 4/4/2004 2:03 PM & $38,246,400$ & $62 \%$ & $14,579,614$ & \\
\hline tion - Uncertaint... & 3/29/2004 2:00 PM & $43,208,192$ & $63 \%$ & $15,899,233$ & \\
\hline uction - Wet TPTP. & 12/15/2003 3:30 PM & $38,245,376$ & $62 \%$ & $14,606,388$ & \\
\hline eat Conduction - Wet TPTP. & 12/15/2003 3:30 PM & $38,246,400$ & $62 \%$ & $14,611,242$ & Heatl \\
\hline Heat Conduction - Wet TPTP. & 12/15/2003 3:30 PM & $38,246,400$ & $62 \%$ & $14,609,919$ & \\
\hline Heat Conduction - Wet TPTP... & 12/15/2003 3:31 PM & $38,246,400$ & $62 \%$ & $14,600,133$ & \\
\hline 16 file(s) & & $020,000,1,0$ & & $236,129,905$ & \\
\hline
\end{tabular}

